\title{
A ENGENHARIA DE REABILITAÇÃO E AS CARACTERÍSTICAS PSICOSSOCIAIS DE PESSOAS COM LESÃO MEDULAR SUBMETIDAS A UM PROGRAMA DE ESTIMULAÇÃO ELÉTRICA NEUROMUSCULAR
}

Dissertação apresentada ao Programa de PósGraduação Bioengenharia Interunidades Escola de Engenharia de São Carlos; Instituto de Química de São Carlos; Faculdade de Medicina de Ribeirão Preto, da Universidade de São Paulo, como parte dos requisitos para a obtenção do título de Mestre em Bioengenharia.

ORIENTADOR: Prof. Dr. Alberto Cliquet Jr

\author{
São Carlos
}


DEDICATÓRIA

Ao grande amor da minha vida, Fransérgio.

As pessoas com lesão medular que participaram desta pesquisa e que hoje se tornaram grandes amigos e companheiros de jornada. 


\section{AGRADECIMENTOS}

Esta pesquisa consistiu em uma caminhada de muitos e um trabalho realizado coletivamente. Agradeço a algumas pessoas em especifico e a outras, que não se encontram citadas aqui, mas que foram colaboradoras, mesmo sem saber ou de forma indireta, para que esta pesquisa fosse realizada.

À minha coorientadora Prof ${ }^{a}$. Dr. Eliane Aparecida Campanha Araújo, por toda a dedicação e apoio empreendido, pelas correções feitas e pela participação constante durante toda a pesquisa.

Ao meu marido Prof. Dr. Fransérgio Leite da Cunha, pois sem ele esta pesquisa não teria sido iniciada ou levada adiante. Pelo seu apoio, paciência, carinho e amor desmedido, despendidos em todos os momentos.

Ao meu orientador Prof Dr. Alberto Cliquet Júnior, por acreditar e possibilitar a realização e conclusão desta pesquisa.

À minha família (pais, avós, irmã e cunhado), pelos valores e exemplos de dignidade, determinação e senso de justiça que sempre estiveram presentes na minha formação. Por compartilharem de forma única de todos os momentos de minha vida sem nunca terem se ausentado. Agradeço ainda aos meus pais e avós, pelo investimento em minha formação, seja ela profissional, intelectual ou pessoal. A meu pai Martin, deixo um agradecimento especial, por ter acreditado, até antes de mim, tão plenamente, na possibilidade deste trabalho.

A família de meu marido, minha sogra Elisabeth, minha também avó, Dona Nair, meus cunhados Nayana, Gui e Fofão e todas as tias, primas e primos que ganhei ao me casar, pelo carinho partilhado e pela forma tão generosa que me receberam em sua família.

Aos meus queridos amigos, Marcela e Erick, Cíntia e Mauro, Melissa, Tatiana, Andréia, Adriana, Daniel e Juciléia, por estarem sempre por perto, compartilhando momentos de alegria e de angústias.

Ao recente, mas já muito estimado amigo João, pela grandeza de sua colaboração, além do estímulo e da confiança depositada neste trabalho.

A Prof. Dr ${ }^{\mathrm{a}}$. Fátima Elisabeth Denari, pelo aprendizado que me proporcionou durante os nossos encontros, além da ajuda, apoio e contribuições fornecidas durante todo o transcorrer desta pesquisa.

Ao Prof. Dr. João Manuel Domingos de Almeida Rollo, por aceitar tão prontamente a fazer parte da banca examinadora e pelo tempo dispensado para avaliar este trabalho. 
A todos os amigos estudantes e pesquisadores do Laboratório de Biocibernética e Engenharia de Reabilitação da Escola de Engenharia de São Carlos - USP

A todas as pessoas que fazem parte do Departamento e Laboratório de Ortopedia e Traumatologia do Hospital das Clínicas da Unicamp, pelo apoio prestado durante todas as etapas deste trabalho. Em especial ao pesquisador Enio por ter estado sempre disponível a esclarecer minhas dúvidas, compartilhar de questões trazidas durante os atendimentos, além da participação constante em eventos em outras atividades de integração desenvolvidas.

À Tereza Galvão, minha ex-psicoterapeuta e atual amiga, que tanto me incentivou em momentos cruciais de minha vida e me ajudou a tomar decisões que foram imprescindíveis para o meu crescimento pessoal e profissional.

A todos os funcionários do Departamento de Engenharia Elétrica da Escola de Engenharia de São Carlos e do Programa de Pós-Graduação em Educação Especial da Universidade Federal de São Carlos, em especial a Marcelo, Zé Carlos, Denise, Marisa, Jussara, Rosane e D. Elza, pelas orientações burocráticas, palavras de apoio e boa-vontade mostradas em todas as ocasiões. Também as alunas Adriana e Cintia, pelas sugestões e companheirismo.

A Clélia Cavalcanti Ferraz, minha atual psicoterapeuta, que muito me ajudou a superar as dificuldades encontradas pelo caminho e continuar seguindo com força e determinação.

A todos os amigos do Espírito Santo que me incentivaram a seguir os meus sonhos: Simone, Alessandra, Tânia, Fabiane, Lílian, Alessandro e Juliana, Gilberto e Elisângela, Gustavo e Lícia, Sônia, Nelson e Patrícia, Isabel, D. Maria Helena, professores e funcionários da Pestalozzi de Guarapari, Evanilda e outros, que mesmo estando longe, foram fontes de carinho e companheirismo.

A minha companheira de profissão e cúmplice, Kátia Wanke, pelos conselhos e orientações e aos professores e companheiros de turma da Universidade Federal do Espírito Santo (UFES), que, de forma indireta ou direta, me ajudaram a realizar esta pesquisa, me ensinando a enxergar a multiplicidade das manifestações humanas.

$\mathrm{E}$, finalmente, àqueles que foram a verdadeira motivação desta pesquisa, os meus amigos "cadeirantes" e seus familiares, pelo imenso aprendizado e enriquecimento que trouxeram a minha vida e a esta pesquisa. Agradeço também pela confiança que em mim depositaram, para o desenvolvimento desta pesquisa. 
Uma fração de segundo e acabou-se o velho mundo...

Desespero! Pois tudo normalmente funcionava e o sonho de uma vida inteira parava...

O amor da ex esposa, que no altar jurou, se evaporou... levou meu filho, o maior tesouro e na cadeira de rodas me deixou...

Confesso: minha nau quase, foi à pique, entretanto, Jesus Deus, me disse, não vai, fique.

Mais uma vez minha mãe, pai e irmão personificaram Deus e me estenderam sua mão!

Batalha renhida, luta, dor, lágrimas e solidão, porém, de meu interior brotou opinião e um coração de leão.

O meu caso tem demonstrado aprendizado e evolução, assim portanto seguirei! Ligado com o Senhor da Criação, embraçando as armas de minha guerra e cheio de emoção, ando com alegria todo dia, sabendo que meu caso tem solução!...

Eduardo Hilkner Otero Cosmópolis, 15 de junho de 2003 


\section{RESUMO}

MANHÃES, R. B. (2004). A Engenharia de Reabilitação e as Características Psicossociais de Pessoas com Lesão Medular Submetidas a um Programa de Estimulação Elétrica Neuromuscular. Dissertação (Mestrado) - Escola de Engenharia de São Carlos, Universidade de São Paulo, São Carlos 2004.

A Estimulação Elétrica Neuromuscular é um recurso reabilitacional funcional que tem como propósito a recuperação dos movimentos dos membros superiores ou inferiores. Com este recurso, é possível a pessoas que possuem uma lesão medular e que vêem suas vidas modificadas pelo advento da lesão, executarem ações que possam facilitar a sua independência nas habilidades diárias, uma vez que mudanças em seu esquema corporal e limitações reais às suas atividades cotidianas são observadas nestes casos. Acredita-se que seja comum a presença de reações psicológicas a este tratamento, porém, poucos estudos foram registrados até o momento. Considerando-se que uma intervenção que aborde aspectos físicos, psicológicos e sociais destas pessoas é indispensável a qualquer processo reabilitacional, esta pesquisa teve como objetivos identificar e analisar características psicossociais de usuários do programa de Estimulação Elétrica Neuromuscular realizado no Hospital das Clínicas da Universidade Estadual de Campinas, Departamento de Ortopedia e Traumatologia da Faculdade de Ciências Médicas, Laboratório de Biomecânica e Reabilitação do Aparelho Locomotor. Suas concepções, reações e expectativas frente a este tipo de reabilitação também foram investigados, além da identificação das principais necessidades destas pessoas, oferecendo subsídios para a condução de um tratamento psicoterápico adequado ao quadro caracterológico das pessoas com lesão medular submetidas à Estimulação Elétrica Neuromuscular, de forma a favorecer a realização de um processo reabilitacional que os contemplem em sua dinâmica biopsicossocial. Para isso, os participantes desta pesquisa foram divididos em dois grupos distintos. Os que se encontravam no primeiro ano de tratamento e os que o realizavam há mais de um ano. Foi utilizado um roteiro de entrevista semi-estruturada que teve como propósito conhecer aspectos, tais como, a visão da pessoa com lesão medular sobre sua própria deficiência, formas de enfrentamento, vida social e familiar, bem como, suas concepções e expectativas no que diz respeito à reabilitação por meio da Estimulação Elétrica Neuromuscular. Os entrevistados consideraram como uma de suas metas, a recuperação total ou parcial das funções que lhes foram subtraídas com a lesão medular, considerando efeitos positivos com a utilização deste tratamento, no alcance de melhorias físicas e psicossociais. Não obstante, eles procuram investir em vários outros aspectos de suas vidas, que não somente o reabilitacional, como por exemplo, os profissionais, familiares, sociais e afetivos.

Palavras - chave: Estimulação Elétrica Neuromuscular; reabilitação; características psicossociais; lesão medular. 


\section{ABSTRACT}

MANHÃES, R. B. (2004). The Rehabilitation Engineering and the Psychosocial Characteristics of Spinal Cord Injured People Submitted to a Neuromuscular Electrical Stimulation Program. M.Sc. Dissertation - Escola de Engenharia de São Carlos, Universidade de São Paulo, São Carlos 2004.

Neuromuscular Electrical Stimulation is a functional resource for rehabilitation, which aims recover the motions of inferior and superior limbs. With this resource, it is possible for spinal cord injury patients, who had their lives changed due to this injury, to execute actions that can make their independency to every day abilities easier, once changes in their body structure and real limitations to daily activities were noticed in this case. It is believed that the remark of psychological reactions are usual for this treatment, however, a few studies were registrated until the moment. In regarding to an intervention that deals with this patients' physical and social aspects is essential to any rehabilitation process, this research aims to identify and analyze users' psycho-social characteristics of Neuromuscular Electrical Stimulation program made at Campinas State University hospital, Orthopedic and Traumatology Department of Medical Science School, Laboratory of Biomechanics and Rehabilitation of Inferior Limbs. Its concepts, reactions and expectations toward this kind of rehabilitation were also investigated, as well as the identification for the leading of a psychotherapeutic treatment appropriate to the characterization of the process of spinal cord injury patients who were subjected to neuromuscular electrical stimulation in order to be biased toward the achievement of a rehabilitational process, which gives to the spinal cord injured person in his/her biopsycho-social dynamic. For this, subjects of this research were divided in two different groups. The first group, people who were in the first year of treatment and the second group, people who had been in treatment for more than one year. A schedule of a half-standard interview was used and aimed to know aspects such as spinal cord injured person's point of view about his/her own disability, how he/she faces it, social and family life as well as his/her concepts and expectations regarding to rehabilitation through neuromuscular electrical stimulation. The total or partial recovering of the functions that were taken by the spinal cord injury was had as one of the patients' goals, which were worried about the positive effects by using this treatment, within reach physical and psychosocial improvement. They tried to invest in many other aspects of life, such as professional, family, social and affective aspects.

Key words: Neuromuscular Electrical Stimulation, rehabilitation, psychosocial characteristics, spinal cord injury 


\section{LISTA DE ILUSTRAÇÕES}

Figura 1. Distribuição dos pacientes por causa de internação (REDE SARAH, 2003).

Figura 2. Distribuição dos pacientes internados por causas externas segundo faixa etária na ocasião em que adquiriram a lesão (REDE SARAH, 2003).

Figura 3. Distribuição dos pacientes por faixa etária na ocasião da lesão, segundo as três principais causas de lesão (REDE SARAH, 2003).

Figura 4. Medula Espinhal: nervos que partem da medula e que regulam o sistema simpático e parassimpático. Adaptado de Mathews, 2000.

Figura 5. Coluna vertebral. A) Coluna cervical; B) Coluna torácica; C) Coluna lombar. 1) Corpo vertebral; 2) Disco intervertebral; 3) Raiz nervosa. Adaptado de Ferrareto (2000).

Figura 6. Múltiplos profissionais envolvidos no processo de reabilitação. Adaptado de LIPPINCOTT (1988).

Figura 7. Linha do tempo dos avanços da bioengenharia e da tecnologia médica. Adaptado de Lavine, Roberts e Smith (2002).

Figura 8. Gerador de eletricidade estática do século XIV (CHERNOVIZ, 1890).

Figura 9. Geradores de corrente elétrica por indução com interrupção, do século XIX. À esquerda: Aparelho magneto-elétrico de Breton e à direita o de Gaiffe (CHERNOVIZ, 1890).

Figura 10. Aplicação da eletricidade na paralisia do braço, segundo Chernoviz (1890).

Figura 11. Restabelecimento da postura corporal.

Figura 12. Efeitos psicossociais da EENM: motivações e expectativas 


\section{LISTA DE TABELAS}

Tabela 1. Caracterização dos Participantes - parte 1.

Tabela 2. Caracterização dos Participantes - parte 2. 55

Tabela 3. Caracterização dos familiares. 57

Tabela 4. Percepção sobre os eventos causadores da lesão medular. 64

Tabela 5. Justificativas dadas para a sobrevivência, para o advento da lesão e recuperação de algumas de suas funções corporais. 66

Tabela 6. Conhecimentos anteriores dos entrevistados sobre a lesão medular. $\quad 68$

Tabela 7. Primeiras reações à lesão medular. 71

Tabela 8. Formas de enfrentamento. 73

Tabela 9: Significado de mudanças ocorridas a partir da lesão. 75

Tabela 10. Efeitos provenientes da lesão medular. 78

Tabela 11. Principais dificuldades enfrentadas pelos entrevistados e pelas pessoas com lesão medular de uma forma geral, de acordo com o depoimento dos entrevistados. $\quad 81$

Tabela 12. Principais necessidades da pessoa com lesão medular. 85

Tabela 13. Situação de vida atual dos entrevistados. 86

Tabela 14. Considerações sobre sua vida social. $\quad 90$

Tabela 15. Como avaliam sua vida social. 90

Tabela 16. Mudanças sociais motivadas pela lesão medular. 92

Tabela 17. Como percebem o preconceito/estigmas ligados à lesão medular. 99

Tabela 18. Reações dos entrevistados ao preconceito social. 103

Tabela 19. Situação de vida: nos estudos, vida profissional e ocupacional. 109

Tabela 20. Obstáculos encontrados no trabalho. 116

Tabela 21. Reações aos obstáculos encontrados no ambiente de trabalho. 117

Tabela 22. Influência da lesão medular no ambiente de trabalho, segundo a percepção dos entrevistados.

Tabela 23. A percepção social da pessoa com lesão medular em seu ambiente de trabalho, segundo os entrevistados. 120

Tabela 24. Reações iniciais da família diante da deficiência, de acordo com os entrevistados. 
Tabela 25. Reações iniciais da família diante da deficiência, de acordo com os familiares.

Tabela 26. Percepção dos entrevistados sobre os comportamentos, sentimentos e expectativas de seus familiares.

Tabela 27. Percepção de familiares sobre seus comportamentos, sentimentos e expectativas no que concerne à pessoa com lesão medular.

Tabela 28. Caracterização do relacionamento dos entrevistados com seus familiares.

Tabela 29. Percepção dos entrevistados sobre a participação dos familiares no seu processo reabilitacional.

Tabela 30. Percepção dos entrevistados sobre a contribuição dos familiares na sua reabilitação.

Tabela 31.Conhecimentos anteriores dos familiares sobre a lesão medular.

Tabela 32. Efeitos relacionados à lesão medular mencionados pelos familiares.

Tabela 33. Percepção dos familiares sobre as formas de enfrentamento utilizadas pelos entrevistados.

Tabela 34. Concepções sobre reabilitação.

Tabela 35. Instituições reabilitacionais freqüentadas pelos entrevistados.

Tabela 36. Avaliação dos entrevistados sobre as instituições reabilitacionais freqüentadas anteriormente.

Tabela 37. Principais benefícios adquiridos em seu processo reabilitacional.

Tabela 38. Como tiveram acesso à EENM.

Tabela 39. Motivos apresentados para participarem do Programa de EENM.

Tabela 40. Situação no Programa de EENM.

Tabela 41. Acesso aos conhecimentos referentes a EENM, obtidos no Programa de EENM.

Tabela 42. Concepções sobre a EENM.

Tabela 43. Mudanças provenientes do tratamento com a EENM.

Tabela 44. Expectativas iniciais e atuais dos entrevistados quanto a reabilitação por meio da EENM.

Tabela 45. Mudanças necessárias para o aperfeiçoamento do Programa de EENM, na opinião dos entrevistados. 
Tabela 46. Aspectos positivos do Programa de EENM, na opinião dos entrevistados.

Tabela 47. Percepção dos entrevistados sobre a constituição da equipe multidisciplinar do Programa de EENM.

Tabela 48. Concepções sobre a inserção do psicólogo no Programa de EENM.

Tabela 49. Tipo de atuação que o psicólogo deve exercer, na opinião dos entrevistados.

Tabela 50. Expectativas para o futuro. 


\section{LISTA DE ABREVIATURAS E SIGLAS}

\begin{tabular}{|c|c|}
\hline AACD & Associação de Assistência à Criança Deficiente \\
\hline$A C$ & Antes de Cristo \\
\hline ABDR & Associação Brasileira de Reabilitação \\
\hline$A D D$ & Associação de Deficientes de São Paulo \\
\hline ASIA & $\begin{array}{l}\text { American Spinal Injuries Association - Associação Americana de Lesões } \\
\text { Medulares }\end{array}$ \\
\hline AVC & Acidente vascular cerebral \\
\hline C1 a C7 & Vértebras da região cervical da coluna vertebral \\
\hline CAIC & Centro de Atenção Integral à Criança e ao Adolescente \\
\hline DOT & Departamento de Ortopedia e Traumatologia da FCM \\
\hline EENM & Estimulação Elétrica Neuromuscular \\
\hline EESC & Escola de Engenharia de São Carlos \\
\hline EUA & Estados Unidos da América \\
\hline $\mathrm{F}$ & $\begin{array}{l}\text { Sexo feminino; quantificação ou freqüência em que as respostas das } \\
\text { pessoas aparecem nas suas falas (representado no cabeçalho das } \\
\text { tabelas) }\end{array}$ \\
\hline$F 1, F 2, \ldots$ & Familiar 1 , Familiar $2, \ldots$ \\
\hline FCM & Faculdade de Ciências Médicas da UNICAMP \\
\hline FES & Functional Electrical Stimulation - Estimulação Elétrica Funcional \\
\hline FNS & $\begin{array}{l}\text { Functional Neuromuscular Stimulation - Estimulação Neuromuscular } \\
\text { Funcional }\end{array}$ \\
\hline $\mathrm{HC}$ & Hospital das Clínicas \\
\hline IBGE & Instituto Brasileiro de Geografia e Estatística \\
\hline L1 a L5 & Vértebras da região lombar da coluna vertebral \\
\hline LABCIBER & Laboratório de Biocibernética e Engenharia de Reabilitação da EESC/USP \\
\hline M & Sexo masculino \\
\hline NMES & $\begin{array}{l}\text { Neuromuscular Electrical Stimulation - Estimulação Elétrica } \\
\text { Neuromuscular }\end{array}$ \\
\hline OMS & Organização Mundial de Saúde \\
\hline OPAS & $\begin{array}{l}\text { Organización Panamericana de la Salud - Organização Pan-Americana de } \\
\text { Saúde }\end{array}$ \\
\hline
\end{tabular}


MPAS Ministério da Previdência e Assistência Social

$\mathrm{P} \quad$ Pessoas relativas às falas (representado no cabeçalho das tabelas, cujo número correspondente está relacionado na mesma)

P1, P2,... Pessoa 1, Pessoa 2,...

PA Pressão arterial

PUC Pontifícia Universidade Católica (no texto refere-se a PUC de Campinas)

séc. Século

SESC Serviço Social do Comércio

SESI Serviço Social da Indústria

SIDRA Sistema IBGE de Recuperação Automática

SM Salários Mínimos

SUS Sistema Único de Saúde

T1 a T12 Vértebras da região torácica da coluna vertebral

TV Televisão

UNICAMP Universidade Estadual de Campinas

USP Universidade de São Paulo 


\section{SUMÁRIO}

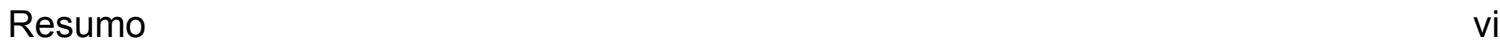

Abstract $\quad$ vii

Lista de ilustrações viii

Lista de tabelas $\quad$ ix

Lista de abreviaturas e siglas $\quad$ xii

$\begin{array}{ll}\text { 1. Introdução } & 1\end{array}$

1.1. A lesão medular: suas repercussões físicas e fisiológicas 4

1.2. As repercussões psicossociais da lesão medular. 9

1.2.1. As mudanças psicossociais 10

1.2.2. O normal e o patológico: Um breve resumo sobre os significados da deficiência física ao longo da história $\quad 21$

1.2.3. As formas de enfrentamento

1.3. A Reabilitação e a pessoa com lesão medular 30

1.3.1. Definindo reabilitação e refletindo sobre sua prática 30

1.3.2. A interface entre tecnologia e reabilitação: história da prática reabilitacional $\quad 35$

1.3.3. Fundamentando a utilização de recursos elétricos nos tratamentos de saúde: um pequeno resumo histórico $\quad 40$

1.3.4. A Reabilitação por meio da EENM 42

1.3.4.1. O Programa de EENM

1.3.4.2. Efeitos psicossociais da EENM em pessoas com lesão $\begin{array}{ll}\text { medular } & 47\end{array}$

1.3.5. Fundamentos para uma reabilitação biopsicossocial 50

2. Hipóteses e Objetivos desta Pesquisa $\quad 52$

3. Método $\quad 53$

3.1. Participantes.

$\begin{array}{ll}\text { 3.2. Contexto do Estudo. } & 58\end{array}$

3.3. Recursos Materiais. $\quad 58$

3.4. Procedimento para Coleta de Dados. 58

3.4.1. Breve descrição da dinâmica das sessões de grupo com os $\begin{array}{ll}\text { familiares } & 61\end{array}$

3.5. Procedimento para análise dos dados. 62 
3.6. Forma de Apresentação dos Resultados. 63

4. Resultados e Discussão 63

4.1. Bloco Temático 1: Percepções em relação a Lesão Medular 63

4.2. Bloco Temático 2: Quanto a vida social, estudos e trabalho 90

4.3. Bloco Temático 3: Quanto ao aspecto familiar 123

4.4. Bloco Temático 4: Quanto a reabilitação 142

4.5. Bloco Temático 5: Concepções e expectativas em relação à EENM 153

5. Considerações Finais 188

Referências Bibliográficas $\quad 205$

Apêndice A - Roteiro de entrevista para caracterização da pessoa com lesão $\begin{array}{ll}\text { medular } & 218\end{array}$

Apêndice B - Formulário para caracterização dos familiares 222

Apêndice C - Termo de Consentimento Esclarecido 224

Anexo A - Sistema IBGE de recuperação automática - SIDRA, tabela 1649 população residente por situação, sexo e tipo de deficiência 226

Anexo B - Parecer do Comitê de Ética da UNICAMP 229 


\section{Introdução}

O desenvolvimento da tecnologia cientifica direcionada para a assistência à saúde tem promovido mudanças demográfico-epidemiológicas, além de proporcionar uma melhor e maior expectativa de vida. Há quarenta anos, algumas patologias crônicas como, por exemplo, as lesões medulares, poderiam se tornar motivos de uma total dependência ou mesmo da ocorrência de óbitos (SOUZA, 1994). Atualmente, com a interação entre a tecnologia e medicina, é possível que pessoas acometidas por uma lesão na medula, com vários comprometimentos físicos e fisiológicos possam, através da ajuda de aparelhos, exercer alguns movimentos que lhes foram subtraídos com o advento da lesão medular.

Não obstante os avanços tecnológicos, pesquisas indicam que associados ao processo de crescimento urbano, industrial e científico ocorridos no século passado, observou-se uma grande aceleração na quantidade de casos diagnosticados como patologias crônicas (IDE e CHAVES, 1992).

A definição de patologias crônicas, ainda aceita atualmente, foi formulada em 1957 pela Comissão de Doenças Crônicas de Cambridge e se baseia em algumas condições específicas, tais como, presença de incapacidades residuais, mudanças patológicas não reversíveis no sistema corporal, necessidade de treinamento e reabilitação e previsão de um período indeterminado de supervisão, observação e cuidados médicos (GREGG, ROBERTUS e STONE, 1989). Estas mesmas características, podem ser encontradas na definição de Timmrich e Surver (1986) no Dictionary of Healthy Services Management. Portanto, uma pessoa acometida por uma patologia crônica, pode ter que modificar todo o seu contexto e estilo de vida (LUBKIN, 1990).

Diante de todas as características remetidas a este conceito, constata-se que a lesão medular enquadra-se nesta categoria, assumindo-se como uma patologia crônica. Vários outros estudos têm revelado um aumento em sua incidência, devido a acidentes automobilísticos, traumatismos por arma de fogo e quedas (FARO,1991,1995; REDE SARAH, 2003; SPÓSITO et. al,1986). Tais acontecimentos têm contribuído para a proeminência de uma 
população de pessoas com lesão medular, bastante significativa. Segundo Carvalho et. al. (1998), o número de pessoas acometidas por esta patologia chega a 20 milhões ao ano, dentro do continente Europeu. De acordo com o último censo demográfico do Instituto Brasileiro de Geografia e Estatística (IBGE) realizado no ano de 2000, observou-se que existem 955.287 pessoas portadoras de deficiência física caracterizada por uma tetraplegia, paraplegia ou hemiplegia permanente (IBGE, 2000), que equivale a aproximadamente $0.56 \%$ da população total do Brasil (169.799.170 pessoas) e a aproximadamente $3.89 \%$ das pessoas com pelo menos um tipo de deficiência das enumeradas por este mesmo censo (ver anexo A). Em pesquisas realizadas pelo Instituto Sarah Kubitscheck ${ }^{1}$ (Brasília e Salvador), no período de fevereiro de 1991 a janeiro de 2000, a lesão medular aparece como uma das principais causas de internação (figura 1), sendo 54,8\% delas resultantes de causas externas, tais como violência e acidentes. Os acidentes automobilísticos revelaram-se como os principais responsáveis por este tipo de patologia, sendo seguidos pelas agressões por armas de fogo, quedas e práticas esportivas. Cabe ressaltar que os acidentes automobilísticos acometem, na sua maior parte, pessoas do sexo masculino. No Brasil, para pessoas acometidas por uma paraplegia, tetraplegia e hemiplegia permanente, foi observada uma proporção de $55.22 \%$ do sexo masculino, contra $44.78 \%$ para o sexo feminino, sendo comprovada uma maior incidência por acidente automobilístico (IBGE, 2000; SPÓSITO, 1986).

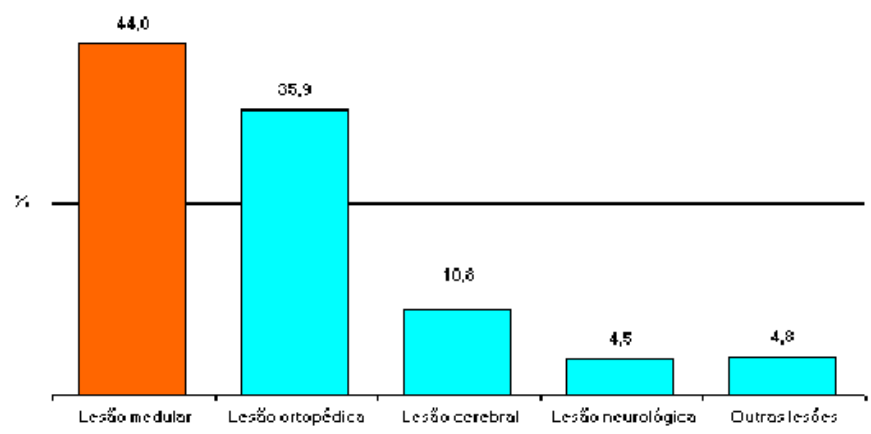

Figura 1. Distribuição dos pacientes por causa de internação (REDE SARAH, 2003)

\footnotetext{
${ }^{1}$ Rede de Hospitais especializados na Reabilitação de Doenças Crônicas
} 
Não obstante, pesquisas realizadas no ano de 1991 já constatavam um aumento gradativo na incidência de lesão medular que ocorrem por meio de ferimentos por arma de fogo (FARO, 1991).

Resultados de vários estudos, realizados em épocas diferentes, mostram que a lesão medular costuma atingir, com maior freqüência, uma parcela da população do sexo masculino considerada jovem, em uma idade que varia entre 15 e 35 anos. (BOGOSSIAN, 1981; FARO, 1991; LEPRINCE, 1981; SANTOS, 1989; SOLOMON, 1982; SPOSITO, 1986, WEINBERG, 1982). Acima de 80\% de pessoas com lesão medular nos Estados Unidos são homens jovens e iniciando sua vida produtiva (CORBET, 1985). As causas externas (violências e acidentes), no Hospital Sarah Kubitscheck, acometeram, principalmente, adolescentes e adultos entre 15 e 39 anos, como pode ser observado na figura 2. É nesta faixa etária que ocorre um maior número de lesões provenientes de acidentes automobilísticos, como pode ser visualizado na figura 3 .

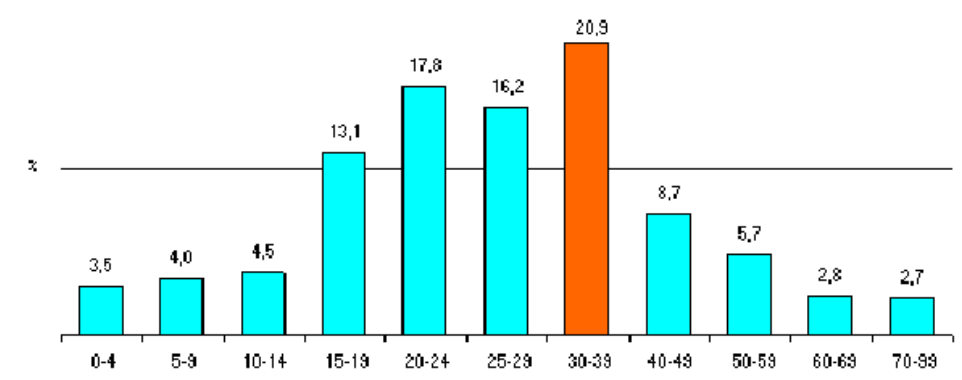

Figura 2. Distribuição dos pacientes internados por causas externas segundo faixa etária na ocasião em que adquiriram a lesão (REDE SARAH, 2003).

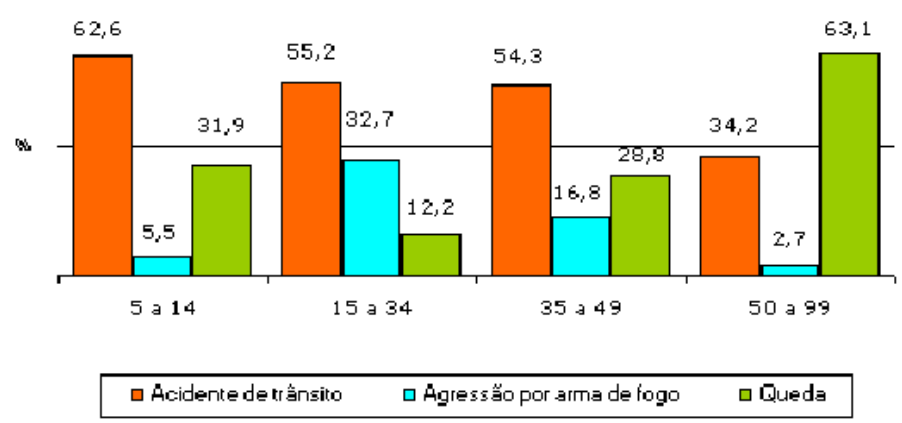

Figura 3. Distribuição dos pacientes por faixa etária na ocasião da lesão, segundo as três principais causas de lesão (REDE SARAH, 2003). 
Diante destas informações, é indiscutível a importância de pesquisas e estudos científicos que se conjugam para alcançar uma compreensão cada vez mais apurada sobre esta população, suas características, seu processo reabilitacional, enfim, toda a complexa gama de acontecimentos que a envolve e, como estas pessoas se comportam frente ao que vem sendo proposto na medicina moderna em direção a um tratamento reabilitacional que as contemplem e todo o emaranhado de conseqüências trazidas por uma lesão na medula espinhal.

As repercussões de uma lesão medular se estendem aos aspectos físicos/físiológicos, psicológicos e sociais. Entende-se que elas encontram-se intrinsicamente relacionadas, de maneira a não ser possível referir-se a cada uma delas como se estivessem separadas ou distantes umas das outras. No entanto, elas foram contempladas, neste estudo, em tópicos diferenciados com o intuito de facilitar a compreensão do leitor.

\subsection{A lesão medular: suas repercussões físicas e fisiológicas}

Apesar da sua rígida estrutura óssea, a coluna vertebral é uma parte frágil e complexa do corpo humano. Ela é composta de vários ossos denominados vértebras, articulados um ao outro, fornecendo uma função estrutural para o corpo e, ao mesmo tempo, formando um canal encobrindo a medula espinhal, que serve para a sua proteção. A medula é um órgão pelo qual passam complexas informações neurais, provenientes do cérebro com destino a todo corpo e vice-versa. Estas são informações de sensações e movimentos, além do sistema de controle das funções simpáticas e parassimpáticas (figura 4).

A medula espinhal funciona, portanto, como uma via de comunicação entre as diversas partes do corpo e o cérebro e, também, como reguladora no exercício de funções vitais ligadas à respiração, à circulação, à bexiga, ao intestino, ao controle térmico e à atividade sexual. Ela percorre por toda a extensão da coluna, iniciando na base do cérebro e terminando com um grupo de nervos denominado de Cauda Eqüina. 


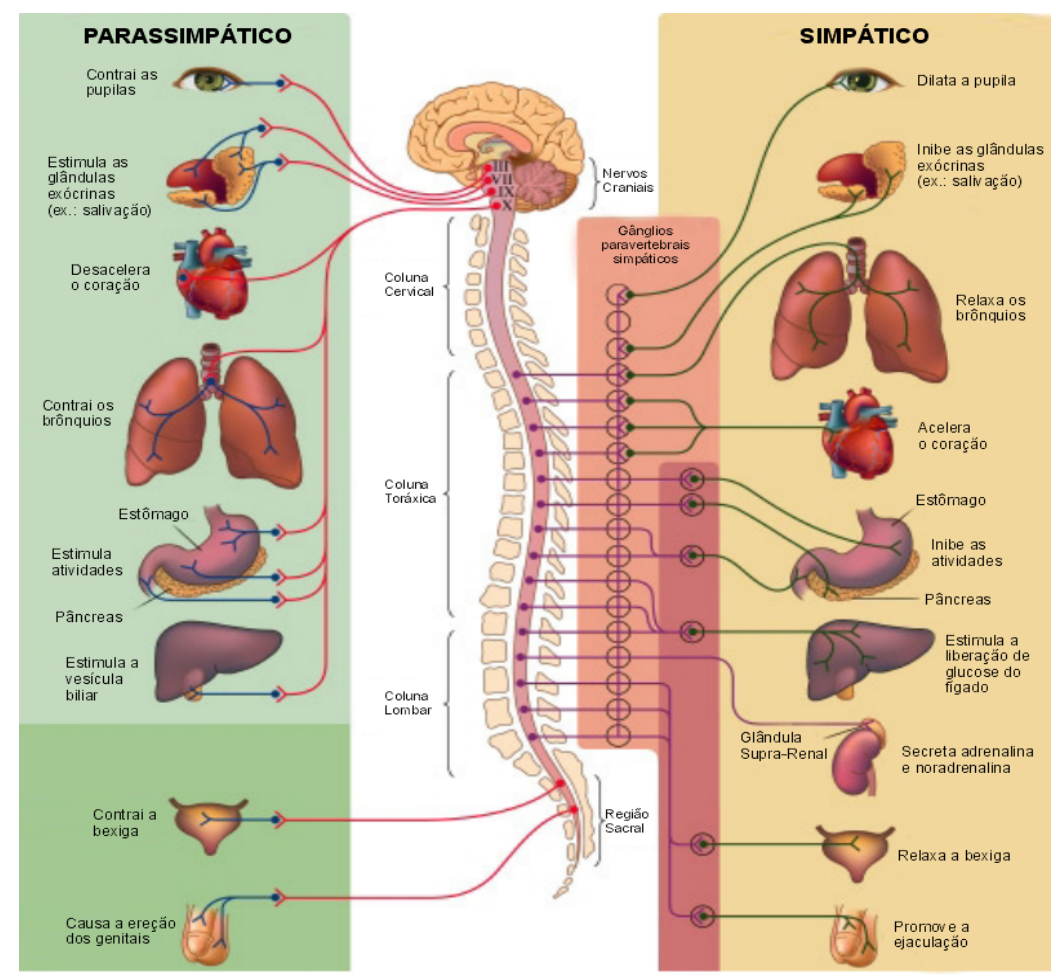

Figura 4. Medula Espinhal: nervos que partem da medula e que regulam o sistema simpático e parassimpático. Adaptado de MATHEWS, 2000.

Caso haja alguma lesão ou dano a este órgão, as informações provenientes do cérebro não poderão ser enviadas às áreas a que se destinariam e, da mesma forma, as informações sensoriais não chegarão ao cérebro. Isso não significa que o cérebro não possa enviar ou receber estas informações, mas apenas que estas não passam pela medula, devido a uma cisão ou falha da continuidade dos neurônios que a compõem. Desta maneira, uma lesão atingindo a medula espinhal, pode causar uma série de incapacidades relacionadas à locomoção, sensibilidade, sexualidade, eliminação de urina e fezes, como também aquelas relativas ao sistema nervoso autonômico. Por este motivo, um traumatismo na medula espinhal é considerado um dos quadros incapacitantes mais graves já conhecidos, até então (LIANZA, CASALIS e GREVE, 1985).

As lesões medulares variam quanto à sua manifestação clínica. Esta, por sua vez, será determinada pela etiologia, nível, grau da lesão no plano transverso e longitudinal, assim como o tempo de instalação das mesmas. 
O nível de lesão diz respeito ao local em que ela ocorre (SCHERB, 1998). Anatomicamente, a coluna vertebral é dividida em regiões que se chamam: coluna cervical (pescoço), coluna torácica (tórax), coluna lombar (cintura), sacro e cóccix - o sacro se articula com a bacia de cada lado e o cóccix é formado por quatro pequenos ossos (figura $5)$.

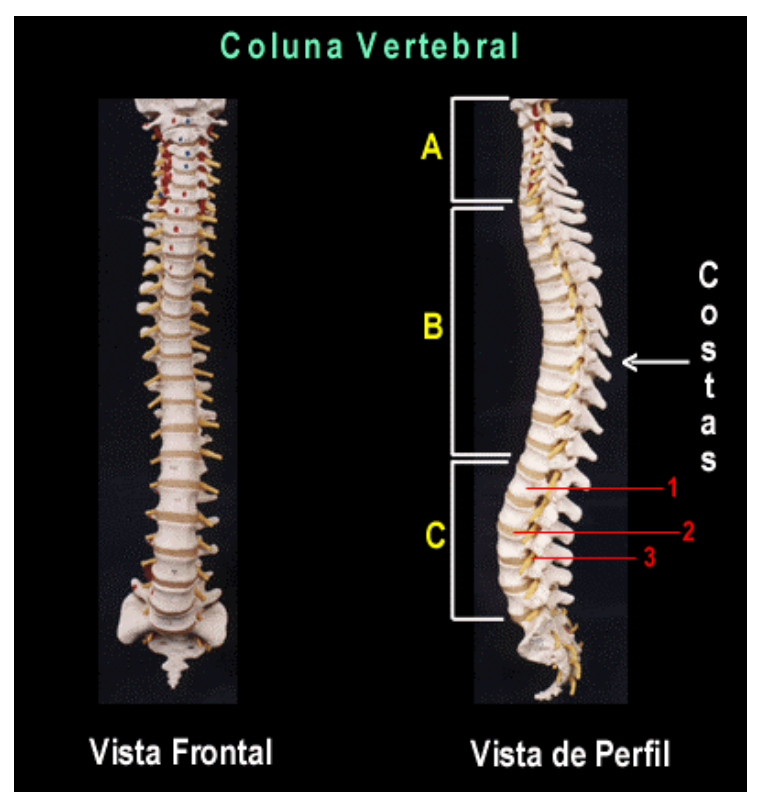

Figura 5. Coluna vertebral. A) Coluna cervical; B) Coluna torácica; C) Coluna lombar. 1) Corpo vertebral; 2) Disco intervertebral; 3) Raiz nervosa. Adaptado de Ferrareto (2000).

Nas duas primeiras regiões ocorrem a maioria das lesões medulares. A região cervical é composta de sete vértebras numeradas de $\mathrm{C} 1$ a $\mathrm{C} 7$ iniciando com a vértebra que se localiza na base do crânio, conhecida também como Atlas. A região torácica vem logo a seguir e possui 12 vértebras denominadas de $\mathrm{T} 1$ a T12. A região lombar possui cinco vértebras, chamadas de L1 a L5. No final da coluna vertebral, logo após a região lombar, surgem o sacro e o cóccix.

As lesões em que há comprometimento dos segmentos medulares que se localizam abaixo de T1, são chamadas de paraplegia e têm como conseqüência a perda das funções motoras e sensitivas dos membros inferiores. Já aquelas que se localizam nos segmentos cervicais determinarão uma tetraplegia, ou seja, perda de movimentos e sensibilidade dos membros inferiores e superiores. Na paraplegia as alterações motoras, sensitivas, autônomas e metabólicas ocorrem em menor intensidade do que na tetraplegia (SCHERB, 1998). 
Observa-se que a classificação utilizada para determinar o nível de lesão está relacionada ao segmento medular que foi acometido. Para esclarecer os efeitos de uma determinada lesão, a coluna foi dividida em segmentos. Desta forma, utiliza-se uma letra que representa uma região específica da coluna e um número para indicar o segmento abaixo do qual se presencia a lesão, de maneira a esclarecer qual o último segmento preservado (SCHERB, 1998), por exemplo: T4, referindo-se a uma lesão na coluna torácica e atingindo a vértebra de número quatro.

O grau de lesão é determinado pelo maior ou menor comprometimento da medula (SCHERB, 1998). Existem vários tipos de lesões medulares, de acordo com a área ou a maneira como ocorreu o trauma (HANAK e SCOTT, 1983; WILSON et al., 1984) mas, segundo Wilson et al. (1984), as lesões medulares podem ser classificadas em dois grandes grupos: lesões completas e incompletas ou parciais.

As lesões parciais podem ser subdivididas de acordo com a área da seção transversal e vertical da medula onde ocorreu o trauma. Em uma lesão parcial, observa-se a preservação de alguns feixes longitudinais e substância cinzenta da medula espinhal, o que fará com que as funções motoras, sensitivas e autônomas do indivíduo não sejam totalmente prejudicadas. Este fenômeno é chamado de paresia (SCHERB, 1998). As lesões completas indicam uma maior limitação funcional, nas quais as chances de recuperar qualquer tipo de movimento são muito remotas ou quase inexistentes.

No que diz respeito à etiologia, as lesões podem ser traumáticas ou não traumáticas, de acordo com as causas que a elas se relacionam. As traumáticas se dão por meio de fraturas, luxações e ferimentos, sejam por armas de fogo, armas brancas, quedas, acidentes automobilísticos, entre outros, e são também compreendidas como lesão medular . As lesões traumáticas ocorrem com mais frequência, com uma média de $2 / 3$ das ocorrências (SCHERB, 1998). Outras causas, relacionadas às lesões não-traumáticas e bastante comuns, são: acidentes vasculares, alongamentos ou compressão do canal medular, infecções e tumores (WILSON et al., 1984). 
Variando de acordo com o tempo de lesão, Lianza, Casalis e Greve (1985) apontam a existência de etapas distintas, que seriam: fase de choque medular, retorno da atividade medular reflexa e, a fase de ajustamento.

A primeira fase pode ser caracterizada pela interrupção de um número significativo de células nervosas. Nela é observado o processo de desorganização, degeneração e reorganização das células. Várias alterações fisiopatológicas ocorrerão, envolvendo paralisia da musculatura situada abaixo do nível de lesão, alterações do sistema nervoso autônomo, alterações esfincterianas e alterações sexuais. Nesta fase não é verificada atividade voluntária ou reflexa ao nível em que a lesão encontra-se instalada (FARO, 1991).

Souza (1994) aponta como intercorrências comuns a esta fase, uma paralisia flácida completa abaixo do nível de lesão, perda total da sensibilidade, disfunções da termorregulação, além de uma tendência maior para a formação de úlceras de decúbito (escaras).

A segunda etapa caracteriza-se pela reorganização funcional das estruturas medulares localizadas abaixo do nível de lesão e uma gradativa estabilidade de sintomas associados às características de uma determinada lesão medular permitindo, assim, que esta pessoa possa restabelecer parcialmente, de acordo com nível e grau de lesão, a sua capacidade funcional. A fase de ajustamento está relacionada com o domínio da pessoa com lesão medular sobre as suas funções vitais. Nesta fase, ocorre uma tentativa de adequação à sua nova condição de tetraplégico ou paraplégico e, por este motivo, é considerada muito importante para o processo de reabilitação. Superada esta fase, esta pessoa encontra-se em condições de interagir de maneira mais independente no seu meio social e comunitário (LIANZA, CASALIS e GREVE,1985).

Com o advento da lesão medular, a pessoa é submetida à devida intervenção médica e iniciará seu tratamento fisioterápico, de modo a se habituar à sua nova condição. Ao mesmo tempo, é instruído para que comece a tomar certos medicamentos e desenvolver cuidados 
específicos para evitar complicações posteriores que podem ser desde escaras, infecções na área urinária e até mesmo a morte, em alguns casos de lesões em níveis bem elevados (FINOCCHIARO e HERZFELD, 1990).

Entre as complicações físicas advindas de uma lesão medular, podem-se citar alguns comprometimentos orgânicos e fisiológicos dependentes do nível e grau em que ocorreu a lesão e caracterizados por perda da sensibilidade no que se refere à dor, frio, calor, tato e até da sua propriocepção postural; redução da capacidade respiratória, disfunção do sistema de regulação térmica, incontinência urinária, descontrole parcial do esfíncter retal, além de predisposições para infecções urinárias, escaras e osteoporose. Vale novamente ressaltar, como conseqüência mais visível e conhecida, a perda ou comprometimento do controle motor (SOUZA,1994).

O grau e número de dificuldades a serem enfrentadas são muito diversificados entre uma pessoa e outra, o que pode ser facilmente explicável se considerarmos tanto as características relacionadas com o tempo da lesão, tipo de lesão (paraplegia ou tetraplegia), tipo e forma física, meios de locomoção disponíveis, a maior ou menor dependência de outras pessoas para exercerem atividades da vida diária, graus de comprometimentos fisiológicos e sexuais, idade em que a lesão foi adquirida, relações sociais e familiares (o impacto da lesão no contexto familiar), a repercussão da lesão em suas atividades ocupacionais ou profissionais, como também seus valores, motivações, concepções de vida e realidade psicossocial que se encontram implícitas, mas determinando suas ações de forma geral.

\subsection{As repercussões psicossociais da lesão medular.}

O enfoque na identidade da pessoa acometida pela lesão medular é essencial para que haja uma compreensão do que ocorre a partir do advento de uma deficiência. Santos, L. (2000) chama a atenção para a total modificação ocorrida na vida destas pessoas, em toda a sua 
maneira de interagir em seu meio-ambiente, no momento em que se percebem como deficientes físicos.

Para que os acontecimentos pós-lesão possam ser esclarecidos, é necessário conhecer a realidade psicossocial dessas pessoas, bem como, os efeitos desta patologia em sua forma de se perceber. Tudo isto estará refletido na auto-imagem que as mesmas possuem. Esta, por sua vez, está intimamente relacionada com as vivências e/ou experiências ocorridas antes, durante e após a lesão.

\subsubsection{As mudanças psicossociais}

As pessoas que apresentam uma lesão medular têm como principal função atingida, a capacidade de movimentar-se por si próprio e, principalmente, de reger e controlar algumas atividades e reações corporais, como por exemplo, a perda da sensibilidade em alguns membros do corpo ou mesmo as dificuldades relacionadas à sexualidade. Isto implica em uma sensação de impotência refletida em situações de dependência e limitação constante, além de acarretar a estas pessoas o "estigma de carreira" de deficiente físico (GOFFMAN, 1988). Tal lesão, entretanto, não compromete a capacidade de pensar e de desejar.

A partir do advento da deficiência, pode ocorrer um confronto entre identidades e papéis já constituídos e a percepção da mudança decorrente das limitações reais que agora lhe são impostas. A pessoa que adquire uma lesão medular necessita de toda uma reestruturação em sua forma de se enxergar, de se entender e de se colocar no mundo. A imagem que ela tem de si mesmo, assim como sua identidade corporal, social, familiar e vocacional, necessitam ser reavaliadas e podem até disassociar-se daquelas construídas anteriormente ao advento da lesão.

Esta pessoa se vê atingida no que diz respeito às suas relações interpessoais. Alguns sentimentos, tais como, vergonha, depressão, ansiedade, medo, preocupação com uma rejeição social ou sexual, inferioridade e abandono são comumente observados em pessoas 
com lesão medular. Pode-se dizer que ela é invadida constantemente por um turbilhão de sentimentos dos mais diversos, estranhos e mesmo contraditórios, em alguns momentos. (FARO, 1991).

Vash (1988) ressalta toda a gama de emoções envolvidas no "tornar-se deficiente". Seriam elas: o medo, a raiva, a tristeza, até o alívio e mesmo alegria. A autora aponta para a importância de se levar em consideração, na análise do comportamento advindo de uma deficiência adquirida, os aspectos subjetivo-individuais ou a realidade subjetiva de cada um, ou seja, a forma como a pessoa com deficiência física se percebe socialmente e os significados que a mesma atribui às suas ações e interrelações. Ocorrerá a formação de uma nova forma de se perceber, estabelecendo-se a sua identidade como deficiente.(BERGER e LUCKMANN, 1983).

A identidade está associada a um conjunto de características próprias e exclusivas de uma pessoa, a saber, nome, idade, estado, profissão, sexo, apresentação física, impressões digitais e outras (FERREIRA, 1986). Ela também se refere a várias características assimiladas com suas experiências de vida, educação e convivência com outras pessoas, formando um indivíduo com valores, conceitos e percepções diferenciadas. Os papéis sociais, profissionais, vocacionais e familiares exercidos nas diversas etapas de suas vidas também terão uma grande contribuição na formulação e reformulação contínua de sua identidade (LARRY, 1988). A presença de uma lesão medular exercerá uma influência significativa, não somente na forma como estas pessoas se identificam, mas também, na maneira como as mesmas se concebem. As mudanças em seu autoconceito e auto-imagem poderão ter conseqüências no comportamento destas pessoas, na relação que elas possuem com o seu próprio corpo ou mesmo na interação estabelecida com outras pessoas (SÁ, 1982).

Rosenberg (1965) já definia auto-imagem como a atitude, opinião e valor que uma pessoa possui sobre si mesma, podendo se estabelecer como favorável ou não favorável. Pode-se dizer que o auto-conceito ou auto-imagem, ou seja, a forma como uma pessoa se qualifica, está intimamente relacionada com o que se pode chamar de identidade pessoal, entendendo- 
se que alterações na concepção que ela possui de si , terão repercussões diretas na maneira com que a mesma se diferencia de outros e forma a sua identidade como sujeito social. Um auto-conceito positivo é aquele em que o indivíduo acredita e explora suas capacidades. Entretanto, alguns fatores são preponderantes para o desenvolvimento de um autoconceito adequado ou inadequado e, entre eles, estão as vivências e experiências que um indivíduo possui. No caso da pessoa com lesão medular, podem ser citadas algumas experiências em comum, como por exemplo a enfermidade prolongada e o sentimento de incapacidade advindos da limitação física. Tais experiências poderiam contribuir para a formação de um auto-conceito negativo.

O fato destas pessoas, com lesão medular, terem que se deparar diretamente com as suas limitações nas suas atividades diárias, faz com que entrem em um processo de reflexão constante sobre as suas capacidades, dificuldades, medos, inseguranças e outros sentimentos similares, que acabam por levar estas pessoas a uma reformulação de sua autoimagem e auto-conceito, além de repercutir concretamente na sua identidade familiar, corporal e social.

Scherb (1998) em estudos que tinham a finalidade de compreender o auto-conceito de pessoas com lesão medular, detectou o sentimento de medo relacionado à sua deficiência. Este medo está diretamente conectado com outros sentimentos, como o de rejeição, que, por sua vez, pode estar remetendo à condição de segregação. Também se observa o medo ligado à produtividade. Medo de serem considerados incompetentes, improdutivos ou não colaboradores. A autora percebe, como conseqüência natural deste medo, um esforço muito grande entre estas pessoas, de corresponder às expectativas sociais de eficiência e produtividade. Muitas vezes, este esforço é bastante perceptível no espaço institucional ou de reabilitação e pode ser reflexo de uma carência afetiva provinda da falta de um espaço onde suas necessidades emocionais possam ser acolhidas e aceitas. Em seu estudo, ela detectou, também, a presença de sentimentos de ansiedade e insatisfação em relação à própria imagem e a do outro. Tiefer (1979) alerta para o fato de que a imagem que a pessoa com lesão medular possui do seu corpo pode estar impregnada por sentimentos de inadequação e inutilidade. 
É importante ressaltar que todas as modificações relacionadas com a afetividade e comportamento, em geral, não devem ser vistas somente como uma decorrência direta do advento de uma deficiência, o que se constata não ser verdadeiro, já que elas estão determinadas por um quadro complexo de intercorrências que nem sempre se relacionam com a deficiência em si, mas com uma conjunção composta pelas suas vivências anteriores e atuais, assim como a forma como percebe e reage a estas vivências.

Segundo Brow (1996), a integração entre a prévia identidade estabelecida na infância e as influências sociais e culturais, torna-se responsável pelos comportamentos observados nestas pessoas durante a sua adolescência e vida adulta. Esta autora enfatiza a busca mais ou menos intensa por uma autonomia e por objetivos de vida mais ou menos saudáveis.

De acordo com Gignac e Cott (1998), até mesmo os conceitos de dependência e independência variam de pessoa para pessoa, constituindo-se em constructos subjetivos e determinados através de valores construídos nas suas vivências psicossociais.

Assim, a compreensão das experiências das pessoas com lesão medular, suas vivências familiares, sociais e culturais são fundamentais para a compreensão do significado da deficiência, bem como, todas as suas implicações, uma vez que esta forma de enxergar a deficiência diferencia-se para cada situação e para cada pessoa envolvida com ela. Isto implica o reconhecimento de histórias de vida diferenciadas. Paula (1993) utiliza o termo "expressões da deficiência" para caracterizar a particularidade da vivência de cada um.

Um aspecto que deve ser considerado, nesta análise, diz respeito à família, suas crenças e valores. Além disso, a maneira como a família encara a deficiência (qual o sentido da deficiência na família e para o próprio deficiente) contribuirá de forma substancial para a construção de uma nova identidade, refletindo-se em uma nova forma de inserção social (ROCHA, 1990). 
A família é considerada o primeiro e mais elementar grupo social. Nela iniciam-se aprendizados fundamentais, nos aspectos afetivos, sociais e comportamentais. Entende-se que no contexto familiar primário, dar-se-á início à formação da identidade. Tal identidade, por sua vez, estará alicerçada em valores transmitidos através do núcleo familiar de origem.

Percebe-se, portanto, que nos dias atuais, a dinâmica familiar assume organizações bastante diferenciadas e diversificadas. Modelos rígidos tidos como padrões ideais ou perfeitos e dados previamente como normais são desmistificados. As diferenças entre as famílias e seus valores tornam-se também gritantes, de acordo com os grupos ou segmentos sócioeconômicos a que nos referimos. Desta forma, é necessário entender as dinâmicas familiares a partir de novas referências, concernentes à sua própria realidade e história. A não consideração deste contexto pode gerar idéias de famílias baseadas em falsas crenças, falsas realidades, falsos valores e expectativas (RIBEIRO, 1989).

Nas definições encontradas na literatura especializada ${ }^{2}$, a família é caracterizada pela relação próxima entre seus entes e não pela proximidade física entre os mesmos. A origem dos membros familiares está determinada pelos vínculos entre eles, tais como, laços consangüíneos e/ou relações afetivas que, por sua vez, encontram-se baseadas na função que cada um desempenha, assim como no grau de socialização e de interação constituídos. (ARAÚJO, 2001). Scabini (1992) considera situações em que havendo uma distância física ou geográfica entre seus membros poderia prevalecer o que ela chama de intimidade à distância. Esta mesma autora também utiliza o termo lealdade intergeracional que está diretamente relacionado com vínculos bem enraizados, implicando em sentimentos de responsabilidade, cuidado e preocupação.

A valorização do vínculo afetivo é uma característica bastante comum nas famílias atuais. A afinidade torna-se outro elo de ligação entre os membros de uma família. As relações não se limitam à consangüinidade ou a continuarem juntos em uma mesma casa, mas elas se

\footnotetext{
2 Algumas definições atuais de família: é uma organização complexa de relações de parentesco que tem uma história e que cria uma história (SCABINI, 1996); reunião de pessoas que mantém um vínculo de afetividade, ligadas pelo apego em que um se responsabiliza pelo outro (BIASÓLI-ALVES, 1996); é a reunião de pessoas ligadas por laços de sangue, adoção e aliança socialmente reconhecida (FUKUI, 1992); duas ou mais pessoas que se relacionam entre si como uma família e que desempenham algumas das funções que as famílias tipicamente desempenham (TURNBULL e TURNBULL, 1997).
} 
ampliam, mesmo quando há rupturas, como é o caso dos vínculos e responsabilidades fraternais mantidos após a separação de um casal.

A família, portanto, pode assumir estruturações diversificadas, como por exemplo, as famílias nucleares, formadas por um pai, uma mãe e filho (os); famílias de pais separados, constituída por um pai ou uma mãe e filho (os); famílias estendidas ou ampliadas, que se referem à participação de outros componentes familiares, como tios e avós, e, finalmente, as famílias extensas ou psicológicas, onde se inserem aqueles componentes que não possuem laços consangüíneos. (NOVAK, 1996).

Com estes entendimentos, em relação a família, é muito importante ressaltar que a problemática do deficiente físico não está restrita a ele, mas ao contrário, engloba todos aqueles que com eles convivem, direta ou indiretamente,incluindo, neste âmbito, todos aqueles considerados por esta pessoa, como constituintes do seu núcleo familiar. Estas famílias, por sua vez, atingidas por um acontecimento como a lesão medular, são marcadas por circunstâncias que acabam por emergir na mudança, e que exigirá um ajustamento gradual da mesma, até chegar ao que Novak (1996) chama de adaptação.

O mesmo autor chama a atenção para um período de transição, considerado crítico e difícil, trazendo com ele sentimentos e comportamentos não habituais, tais como, frustração, medo, insegurança, ansiedade, depressão, irritabilidade e conflitos de diferentes níveis. É um período de desorganização, em que os padrões familiares necessitam ser modificados e a forma de se chegar a um novo ajustamento dar-se-á através de tentativas de adequação entre o que lhe serviu no passado e o que lhe exige a nova realidade. Felizmente, todas as dificuldades comuns a este período não são permanentes e, muito menos, patológicas mas, ao contrário, refletem o esforço desta família de se reestruturar e se adaptar a uma nova forma de ser enquanto família.

Neste contexto, é muito importante ressaltar que o lugar ocupado ou o papel exercido pelo deficiente nas relações familiares, bem como, as reestruturações nos papéis familiares, a 
partir de uma deficiência, são fatores primordiais para a compreensão de algumas das reações das pessoas acometidas por uma patologia considerada incapacitante.

ROCHA (1999) reporta alguns sintomas bastante comuns no âmbito familiar, como super proteção do filho deficiente, dupla dependência (mãe-filho), filhos normais abandonados no cuidado em detrimento do filho deficiente, pais ausentes no tratamento, mães agressivas ou tensas, filhos passivos ou dependentes, entre outros.

A busca incessante da cura é uma característica bastante comum entre os familiares. Muitas vezes, a vida de um ou de todos os integrantes da família passam a se confundir com a vida do deficiente, de maneira a estabelecerem os mesmos objetivos de vida ou colocarem as suas vidas em função destas pessoas. Tais comportamentos atingem diretamente o portador de deficiência e suas reações de uma forma geral.

A família poderá iniciar o processo de segregação e de discriminação e, muitas vezes, o de isolamento, quando infantiliza o deficiente, quando o superprotege, quando o enxerga e o denomina como coitado (vitimização), quando o renega ou quando se nega a acreditar no seu potencial de vida (ROCHA,1990). Também se entende que a responsabilidade de prover todos os cuidados necessários ao deficiente, pode ser uma fonte de desestruturação emocional desta família, trazendo como conseqüência uma grande tensão nos seus membros. Neste sentido, a presença da deficiência pode se constituir em um agente estressor importante (WILLIANS e AIELLO, 2003). Em contrapartida, existem estudos comprovando que o nível de tensão não está associado à existência ou não de uma pessoa deficiente na família (HARRY, 1992; KALYANPER e RAO, 1991). Alguns autores afirmam que a deficiência não tem que estar necessariamente associada a sentimentos de angústia por parte de seus familiares, de forma que as contribuições que estes membros trazem às suas famílias, torna-se um ponto importante neste contexto (DIEHL, MOFFIT e WADE, 1991; JONES et. al., 1995; NATIONAL COMISSION ON CHILDHOOD DISABILITY, 1995). 
A intervenção reabilitacional como linha de pesquisa e de trabalho, deve considerar a pessoa com lesão medular, como fazendo parte de uma ampla rede de interações e interrelações. Por este motivo, o aspecto familiar deve ser abordado de maneira que a família, como definida anteriormente, possa ter papel ativo em todo o processo reabilitacional. De acordo com Minuchin e Fishman (1990), a família do reabilitando deverá estar incluída no tratamento, sendo assistida e fazendo parte dele, desde o início da reabilitação.

É essencial considerar a importância do suporte oferecido pela família, principalmente, se o ambiente familiar adquire uma tendência facilitadora para movimentos de maior independência e formação de vínculos afetivos, de maneira que a pessoa, acometida por uma lesão medular, sinta-se mais à vontade no sentido de realizar interações sociais e realização pessoal.

A falta de controle sobre alguns impulsos corporais é um dos fatores importantes, podendo trazer a esta pessoa a sensação de perda de uma estabilidade e de controle de si mesmo (integridade psicofísica). As ocorrências imprevisíveis de contrações musculares involuntárias, ereção reflexa irregular, entre outras, são comuns nestes casos. Novaes (1975) ressalta que perturbações na função excretora podem ser responsáveis por sentimentos de culpa e de vergonha, trazendo uma sensação de infantilidade e preocupação constante com as repercussões sociais que este distúrbio acaba causando.

Surge, então, a ansiedade direcionada à busca de um controle mais eficaz dos impulsos e respostas corporais, principalmente, em relação àqueles que apresentam menos tempo de lesão ou mesmo àqueles que necessitam realizar maior número de deslocamentos e readaptações posturais, como por exemplo, os que trabalham regularmente (SCHERB, 1998).

Em alguns casos, a dificuldade relacionada com a produtividade ou execução de um trabalho pode ser um complicador para a pessoa acometida por uma lesão medular, já que a dependência financeira, a dificuldade em se adaptar a um determinado trabalho ou de obter um que seja adequado às suas necessidades, quando associados ao sentimento de 
inutilidade, podem se tornar motivos de crises depressivas e de insegurança. Várias repercussões em sua vida profissional podem ser visualizadas a partir destas dificuldades, como por exemplo, a interrupção abrupta de planos de carreira ou mesmo do exercício de uma atividade ocupacional (FARO, 1991). A principal alteração observada diz respeito à auto-estima, podendo-se notar em muitos casos, uma necessidade maior de afeto, reconhecimento e sentimento de utilidade.

As trocas afetivas, por exigirem uma dependência maior nos relacionamentos empreendidos, podem se tornar um aspecto conflituoso para estas pessoas, já que, muitas vezes, ocorre a necessidade de efetivarem uma série de reformulações em seus relacionamentos afetivos, nas quais os papéis exercidos entre os parceiros ou cônjuges encontram-se em constantes mudanças (SCHERB, 1998). As limitações sexuais fazem com que os ajustamentos e/ou reformulações em seus relacionamentos afetivos comecem a se tornar uma necessidade. $\mathrm{O}$ sentimento de impotência relacionado à sexualidade faz com que se sintam em uma posição inferior frente a seus parceiros, assumindo um caráter desconcertante para estas pessoas e interferindo na sua imagem corporal, já que seu corpo é percebido como sendo defeituoso e inútil, principalmente, entre a população masculina. $\mathrm{O}$ medo da impotência e de uma gravidez indesejada também são muito comuns nesta população, de forma a obstruir a realização de uma vida sexual e trazendo transtornos que chegam a impossibilitar a vivência de uma relação afetiva prazerosa. Assumindo-se e concebendo-se de forma inferiorizada, esta pessoa apresenta problemas contínuos em seus relacionamentos (FARO, 1991).

Segundo Novaes (1975), casais que apresentam este tipo de problemática, em grande parte dos casos, já possuíam uma relação conflitiva anteriormente à ocorrência da lesão. No entanto, as dificuldades provenientes desta patologia acabam por prejudicar ainda mais o relacionamento conjugal destas pessoas.

Todas estas reações encontram-se associadas à imagem corporal. De acordo com Mayer e Eisunberg (1988), a imagem corporal significa o conjunto de informações, percepções, assim como sentimentos conscientes e inconscientes relativos ao corpo. Movimentos em 
busca de uma nova imagem corporal são empreendidos por estas pessoas, a partir do advento da lesão medular. Para isto, elas necessitam conhecer profundamente suas limitações e modificações corporais trazidas pela lesão. Além disto, precisam internalizar e se adaptar a este novo corpo, juntando-se a ele uma gama de aparatos de ajuda utilizados no seu dia-dia, tais como, cadeira de rodas, coletor de urina e outros. O reconhecimento deste corpo, com todas as dificuldades trazidas por ele, implica na adaptação aos utensílios de ajuda, como também, na percepção das possibilidades de locomoção que tais artifícios promovem. A partir deste momento, estabelecem-se novas maneiras de vivenciar as experiências corporais (FARO, 1991).

Quando estas pessoas conseguem se perceber como diferentes, e não como limitadas, elas começam a viver de maneira mais satisfatória, realizando-se em seus papéis sociais, vocacionais e familiares e assumindo a sua identidade como deficiente, mas não como incapacitada e exercendo a sua autonomia (PAULA, 1993). E, para que possam assumir a sua identidade psicossocial plenamente e alcançar a sua autonomia, faz-se necessária toda uma reestruturação na assistência social, laboral, psicológica e pedagógica prestada a estas pessoas, como as relativas às facilidades arquitetônicas, serviços de assistência médica mais adequados, assim como o acesso irrestrito à educação e ao mercado de trabalho (DEJONG, 1979).

Algumas práticas chamadas reintegradoras surgiram, a partir dos anos 60 , com o objetivo de garantir ao deficiente o direito de exercer atividades consideradas comuns ao cotidiano social (BRASIL, 1994). As manifestações destas práticas eram pautadas na adaptação da pessoa deficiente ao modelo social que lhes era imposto (SANTOS, 1995; SANTOS, M. 2000; SASSAKI, 1998). Outro movimento, ocorrido na década de 90, voltado principalmente, para as práticas de formação escolar e profissional destas pessoas, é a chamada inclusão, endossado pela Declaração de Salamanca sobre Princípios, Política e Prática em Educação Especial (1994). Este movimento enfatiza, não somente a possibilidade de integração do deficiente a sociedade, mas também, a necessidade desta mesma sociedade, de implantar mudanças, que possibilitem a este deficiente, provido de suas peculiaridades, uma participação mais ampla no seu contexto social. 
Políticas implementadas como a lei de número 7.853/89, que dispõe sobre os direitos das pessoas portadoras de deficiência da Coordenaria Nacional para Integração da Pessoa Portadora de Deficiência (CORDE), garantem a igualdade e dignidade destas pessoas, vedando qualquer forma de preconceito e discriminação e cabendo à sociedade as adaptações necessárias para que estas pessoas possam usufruir de seus direitos à educação, saúde, trabalho, lazer e outros (Brasil, 1989). A lei de Diretrizes e Bases da Educação Nacional (9394/96, LDBEN), discorre sobre o atendimento da necessidade educacional das pessoas com alguma deficiência, a partir da oferta de educação especial quando necessária, com adaptação de currículos, métodos, técnicas, recursos educativos e organização, visando com isso o exercício de práticas profissionais e/ou vocacionais, com o fim último de integrar estas pessoas na vida em sociedade. $\mathrm{O}$ direito de obter as condições necessárias para sua inserção no mercado de trabalho, é portanto, um dos aspectos enfatizados (MAZZOTTA, 1996).

Sabe-se, entretanto, que a existência de conceitos pré-concebidos e não realísticos sobre a deficiência física, encontram-se impregnados, não somente no contexto familiar, mas também no meio social, de uma forma geral (QUEIROZ, 1995). A pessoa estigmatizada é vista de forma inadequada e pré-concebida, não sendo devidamente contemplada em sua totalidade. Desta maneira, ela poderá ser reconhecida por meio de sua identidade social real ou virtual. Ressalta-se, neste contexto, que o corpo deficiente ainda é visto como um "desvio da norma" e estando o deficiente físico em uma situação especial frente à sociedade, ele torna-se um "estigmatizado", um ser desviante, sujeito ao descrédito social (GOFFMAN, 1988).

A forma como a deficiência é compreendida por esta pessoa, as concepções que possui sobre suas limitações, grau de expectativa e conhecimento sobre a sua patologia, assim como a sua compreensão sobre o que é ser um deficiente físico em uma sociedade estigmatizante, tornam-se aspectos primordiais para um estudo que almeje perceber as conotações de uma lesão medular. 
Diferentemente de uma reação de recusa ao estigma de incapacitado, uma visão estigmatizada pode ser internalizada pela própria pessoa de maneira que a construção de sua identidade social esteja contaminada por sentimentos de desvalorização sobre si mesmo. Isto poderá causar sua fragilização e, muitas vezes, tendo como conseqüência, a sua segregação, já que se sente excluído do meio social. (ROCHA, 1990).

Observa-se, a partir de todas estas constatações, que a conscientização e o fortalecimento de uma nova identidade social, familiar, profissional e corporal, torna-se fator primordial para que a pessoa com lesão medular consiga empreender um novo significado ao seu papel como sujeito ativo dentro da sociedade em que vive.

Para compreender as concepções e os estigmas que permeiam a palavra deficiência, faz-se necessário esclarecer todo o contexto histórico-social envolvido nesta conceitualização. Quando investigada na sua origem, pode-se perceber a relação estabelecida entre os conceitos de doença, patologia e deficiência, construídos durante toda uma trajetória de dominação dos desígnios médico-reabilitacionais aceitos socialmente.

\subsubsection{O normal e o patológico: Um breve resumo sobre os significados da deficiência física ao longo da história.}

Os fatores sociais são fundamentais na determinação do processo de assimilação da deficiência, manifestando-se através das variadas formas de transmissão de preconceitos, da marginalização social e, também, na hospitalização, de acordo com os modelos de reabilitação adotados, já que o termo deficiência por si mesmo, costuma estar vinculado com sentimentos de diferenciação e discriminação. Isto se deve à construção da representação social deste conceito, do qual mudanças na concepção e nas idéias predominantes sobre a deficiência ocorrem durante todo um período histórico e social. 
Segundo Amaral (1996), o conceito "deficiência", assume diversos significados de acordo com a sociedade, a época e até em relação aos indivíduos. O conceito de anormalidade, de doença e o subsequente conceito de patologia caracterizarão a história da deficiência.

Durante o século V AC, uma malformação corporal era considerada motivo suficiente para que um recém nascido fosse sacrificado. Cultuava-se a "pureza" dos corpos e, por isto, era necessário que ele fosse controlado na sua forma e função. $\mathrm{Na}$ antiguidade, os valores vigentes recomendavam a eliminação de qualquer atitude que revelasse uma desobediência aos preceitos morais da época. Era dever do adulto, ordenar, arrumar, ensinar, enfim, "higienizar", afastando os corpos infantis da imoralidade e criando, desta forma um corpo moldado para obedecer aos preceitos que lhe eram infringidos (LEVIN, 2001). Com o Renascimento, houve a dessacralização do corpo humano, já que a partir daí foi possível a realização de intervenções científicas sobre o mesmo, transformando-o em objeto da ciência (LUZ, 1988). Este momento histórico é marcado pelo mecanicismo cartesiano. O corpo humano é entendido como uma máquina dotada de um conjunto de mecanismos com leis próprias de funcionamento. Surge a filosofia cartesiana que concebe o corpo como autômato e externo ao eu-pensante. Ele se torna, então, de natureza material e submetido a um comando superior, denominado de alma (ROCHA, 1990).

No século XVII surge uma nova abordagem do corpo humano originada pelas idéias da filosofia naturalista-empirista. O corpo humano passa a ser submetido às leis da natureza e não mais à alma. Ele se torna "algo natural". Possui funções e finalidades próprias, constituindo-se como uma totalidade, sendo sua função mais importante a de sobrevivência (CHAUÍ, 1984). A doença, no final do século XVIII, também adquire um novo sentido. Ela é vista como passível de estudos, já que possuidora de previsibilidade. A doença passa a ser explorada e conhecida em seus mecanismos e sintomas (LUZ, 1988). Deixa de ser um ente absoluto para se tornar um desvio da norma observada na clínica e laboratórios e torna-se uma "patologia" (BERNHADT, 1983). Neste contexto, inicia-se um embate contra as doenças e enfermidades, ou seja, contra as patologias. As intervenções médicas se sobrepõem no sentido de alcançar um "padrão de normalidade orgânica". Alguns termos são introduzidos no discurso comum e social da época, como por exemplo, a idéia de 
normal e patológico, provenientes da medicina. Ao corpo humano, portanto, torna-se primordial estar dentro dos padrões considerados normais.

No século XIX, a medicina e as ciências sociais fazem uma análise do patológico e a deficiência, entendida como uma patologia, torna-se alvo de estudos, classificações, assim como objeto de intervenções específicas. Ela é vista como uma anomalia da natureza e as intervenções precisam ocorrer no sentido de curá-la ou torná-la o mais próximo possível da considerada normalidade (ROCHA, 1999).

A deficiência é, então, classificada em mental, física ou perceptiva/sensorial (auditiva e visual). Para cada uma delas são realizadas formas de intervenção específicas, que por sua vez, ocorrerão em instituições especializadas. A medicina passou a detectar as causas destas patologias, de modo a exercer igualmente um caráter preventivo e não só reabilitacional. Surgem, neste século, as intervenções higienistas e sanitaristas que propõem mudanças no corpo social (ROCHA, 1990).

As mudanças em relação ao próprio conceito de doença que ocorreram no séc. XIX fizeram com que a idéia de um corpo doente individual fosse sendo substituída pela de um corpo social doente. A doença, baseada nesta visão, é compreendida como uma construção histórico- social. Desta forma, também a deficiência adquire um novo sentido: de individual para social, trazendo à tona os conceitos de incapacidades e desvantagens, já consideradas pela Organização Mundial da Saúde (OMS) em 1972, quando o termo deficiência passa a ser visto de uma forma mais ampla. Nas definições propostas pela OMS, com publicação oficial da Internacional Classification of Impairments, Disabilities and Handicaps: a manual of classification relating to the consequences of disease em 1980 e traduzido para o português em 1989 com a denominação de: Classificação Internacional das Deficiências, Incapacidades e Desvantagens: Um manual de classificação das consequências das doenças (OMS, 1989), são estipuladas novas maneiras de compreender a deficiência e suas manifestações. 
Estas concepções acabam por recontextualizar a questão do deficiente, a partir do momento em que contempla toda a gama de problemas relacionados à deficiência e não só o quadro biológico da mesma ampliando, assim, o campo de intervenção e modificando a forma de se conceber a deficiência (ROCHA, 1999). O conceito de deficiência, neste momento, desvincula-se da idéia de doença e passa a ser contemplado, também, no seu âmbito social. A deficiência passa a ser compreendida a partir de três vertentes simbolizadas pelos conceitos de deficiência, incapacidade e desvantagem. Deficiência, neste entendimento, refere-se somente a perda ou anormalidade de uma estrutura ou função do organismo. Incapacidade diz respeito às seqüelas que se refletem em restrições na execução de atividades, observadas a partir de uma deficiência. Desvantagem, por sua vez, está relacionada com a condição social ou com o prejuízo que o deficiente pode ter no que se refere à sua vida na sociedade em que está inserido (AMARAL, 1996).

Entretanto, observa-se também no século XX, o surgimento de uma nova realidade social que acaba por modificar as concepções de corpo visualizadas até então. O corpo passa a ter um significado e objetivo diferenciado. Ele é visto como objeto de observação, manipulação e controle. Seu objetivo é atender às necessidades da sociedade burguesa e capitalista, como uma ferramenta de trabalho. O trabalho torna-se o valor mais importante. É a principal virtude do homem (CHAUÍ, 1984). Surgem, então, as técnicas de adestramento, correção, vigia e punição dos corpos, de forma a se adaptarem ao sistema de produção e à disciplina a ele imposta (FOUCAULT, 1985). O valor humano está na capacidade de trabalho e a doença associa-se ao corpo não produtivo, o que determinaria, por sua vez, um desvio da norma (ROCHA, 1990). O corpo deficiente encontra-se ainda hoje caracterizado dentro desta concepção, sendo visto e compreendido como um "desvio da norma".

De acordo com Ferreira (1986), “desvio", refere-se ao ato ou efeito de desviar-se, ou ainda, afastamento da direção ou da posição normal. Goffman (1988), refere-se à utilização de termos específicos, tais como, aleijado, manco, coxo e outros, referenciados socialmente para designar pessoas acometidas por uma deficiência física, de forma a diferenciá-las das ditas "normais". 
De acordo com Amaral (1996), este afastamento de uma posição considerada socialmente normal, estaria simplesmente refletindo as possibilidades e diversidades humanas. De acordo com esta autora, a deficiência se sobrepõe como mais uma condição humana e o sujeito deficiente deve ser contemplado em toda a sua unicidade, ressaltando sua participação histórica na sociedade na qual faz parte.

Esta forma de perceber o deficiente não é muito comum na sociedade em que vivemos, já que, com muita freqüência, concepções pré-determinadas o colocam em situação de desvantagem perante os outros não-deficientes, conforme já mencionado anteriormente. Esta é uma visão estigmatizada e pode ser reconhecida quando ocorre uma desqualificação ou um descrédito em relação à capacidade real da pessoa com lesão medular, quando este se encontra no exercício de papéis comunitários, afetivos e mesmo profissionais que caracterizarão a sua identidade "deteriorada" como sujeito social (GOFFMAN, 1988).

Paula (1993) destaca que a deficiência, por si só, remete a uma situação de segregação e marginalização, visto a condição de desvantagem social em que as pessoas que se apresentam como deficientes enfrentam. A autora entende que, embora os conceitos estigmatizantes relacionados ao deficiente definam a sua condição social, a maneira como os mesmos percebem a sua deficiência e se colocam perante esta sociedade, pode contribuir significativamente para uma desmistificação destes conceitos.

As formas com que as pessoas acometidos por uma lesão medular enfrentam esta situação e, também, como estabelecem a sua nova identidade como deficiente, são fatores fundamentais para um maior esclarecimento de como elas exercem o seu papel social.

\subsubsection{As formas de enfrentamento}

Para Bray (1978), uma lesão medular pode vir acompanhada por uma crise que se apresenta em três fases bem distintas, caracterizadas por ansiedade, acomodação e assimilação. Na 
fase de ansiedade podem ser observadas as reações de choque e negação, ou mesmo negativismo, através da fantasia e fuga da realidade. O processo de acomodação e posterior assimilação, irão concretizar-se logo após o reconhecimento da realidade. Vash (1988) apresenta três estágios fundamentais, caracterizados pelo reconhecimento dos fatos, aceitação das implicações que o mesmo traz e acolhida da experiência. Entretanto, todas estas mudanças são vividas diferentemente para cada pessoa, levando-se em consideração suas vivências anteriores à lesão, tais como, crenças, valores, percepção, papel social, atividade desenvolvida e interação com a família, comunidade e meio ambiente (SÁ, 1982).

Um aspecto a se considerar é o sentido e o significado que as perdas advindas da lesão medular tiveram em suas vidas e como ocorreu a elaboração destas perdas, por parte deste sujeito. Para isto, é necessária uma avaliação da vida de cada indivíduo durante, após e anteriormente à ocorrência da lesão medular. Em pesquisas realizadas por Santos, L. (2000), constatou-se, por exemplo, que pessoas com uma história anterior de maior independência pessoal e profissional podem apresentar, mais constantemente, sentimentos, tais como, angústia, tristeza ou insegurança. Outro aspecto bastante pertinente é a idade em que esta lesão se fez presente ou que acontecimentos pertencentes à vida desta pessoa estavam ocorrendo no momento em que foi lesionada.

Conceitos, tais como, adaptação, ajustamento, enfrentamento, aceitação e mesmo a idéia de transcendência, são comumente utilizados pela literatura e pelo senso comum para se referirem a maneiras mais desejáveis de se lidar com a deficiência. Segundo Ferreira (1986), adaptar significa tornar apto, por em harmonia, acomodar, adequar. A palavra ajustamento possui significado muito próximo à anterior, encontrando-se intimamente relacionada com os termos adaptação, amoldamento, conformação e ajuste. Aceitar possui um sentido mais amplo, consistindo em estar de acordo com; concordar com; conformar-se realisticamente com o fato. De acordo com Vash (1988), aceitar a deficiência consiste em uma forma de vivenciá-la, marcada pela percepção da mesma como mais uma dificuldade, mas não como o fim de uma vida. Para esta autora, a imagem que a pessoa com lesão medular possui de si mesmo deve ser a de uma pessoa com algumas limitações, que podem 
ou não ser superadas, e não como um incapacitado. Ele estaria, desta forma, assumindo a sua identidade real como deficiente e "ser social".

A palavra transcender, de acordo com Ferreira (1986), significa ser superior a, exceder, passar além de, ultrapassar. Este termo, quando utilizado em relação a uma patologia crônica, pode ser compreendido como uma forma de perceber a deficiência que ultrapassa os limites do que é visível ou palpável. É enxergar para além da experiência concreta, ou seja, procurar apreender significações para a patologia, que não se encontram explícitas ou já determinadas. Vash (1988) chama a atenção para a possibilidade, também, de ultrapassar o conceito de normalidade, difundido no meio social. Desta forma, ao transcender a sua deficiência, esta pessoa estaria assumindo o seu direito de ser única e diferente, com todas as peculiaridades comuns à sua patologia.

Alguns autores como Hanson, Buckelew e Hewett (1993), referem-se às habilidades de ajuste. Estas habilidades estão relacionadas com formas próprias de lidar com a deficiência sem se ver agredido ou prejudicado. Tais habilidades são adquiridas através de um longo e doloroso processo pessoal de reconstrução da identidade (GOFFMAN, 1988; MENDES, 1998). Há um redimensionamento de significados dados a situações vivenciadas por esta pessoa, de maneira que as limitações e dependências ocasionadas pela lesão e os sentimentos e reações daí surgidos vão sendo dimensionados e redimensionados, a partir de uma nova elaboração de significados e valores. Esta pessoa se vê impulsionada a tomar decisões que lhes ajudem a encontrar alternativas e possibilidades nas quais poderá encontrar sentido para sua vida (SANTOS, L. 2000).As suas dificuldades médicas podem ser pioradas se elas não resolverem suas frustrações em relação à sua nova condição, podendo não alcançar sua própria superação ou habilidades de ajuste.

Neste contexto, é possível citar alguns comportamentos observados em pessoas que foram acometidas por uma lesão medular, como por exemplo, os casos de óbitos determinados por uma atitude autodestrutiva, que, por sua vez, encontra-se relacionada com uma pobre habilidade de ajuste ou superação após a lesão (BRYAN e HEIJANIC, 1980; HANSON, BUCKELEW e HEWETT, 1993). No entanto, de acordo com alguns estudos, existe sempre 
uma reação da família e da pessoa afetada para restaurar, substituir, compensar e preservar sua integridade (ROCHA, 1999).

Olson et. al, (1983), quando se referem a formas de enfrentamento, observaram a existência de estilos diferenciados. Seriam eles, avaliação passiva ou "conformismo", "reformulação" e os suportes espirituais, sociais e profissionais. Na "reformulação" há uma mudança no modo de pensar e encarar as situações e uma visão das contribuições positivas que uma deficiência pode trazer para si mesmo, ocorrendo, neste caso, uma análise real de seus limites e ênfase em suas possibilidades. A avaliação passiva, ao contrário da reformulação, encontra-se relacionada com uma percepção negativa da deficiência, marcada pelo sentimento de desânimo ou pela impossibilidade de mudanças e melhorias, sejam elas pessoais, sociais e até mesmo reabilitacionais.

O suporte espiritual está relacionado com a fé ou com algo que transcende a sua vontade. Neste caso, pode-se citar a busca de uma explicação espiritual para os acontecimentos de sua vida e, portanto, para o estabelecimento de uma deficiência, que pode ser compreendida como um sinal ou mesmo como um castigo. Outra característica bastante observada, nestes casos, refere-se ao início de uma crença espiritual a partir do advento da deficiência, de maneira que um novo significado, ligado às crenças num poder divino, passa a estar associado às suas ações, servindo como um suporte necessário na superação de suas perdas. $\mathrm{O}$ apoio em uma força maior, em um deus com poderes ilimitados, passa a ser evidente e suas esperanças e expectativas estão sobrepostas ao desejo deste ser superior (SASAHARA, 1980). No suporte social, observa-se a busca de sustentação naqueles considerados amigos. E, finalmente, no suporte profissional há uma confiança e espera em relação a um trabalho reabilitacional que possa estar sendo realizado no sentido de alcançar uma recuperação dos prejuízos trazidos pela lesão (OLSON et al, 1983)

É importante ressaltar, entretanto, que todas estas formas de enfrentamento podem se encontrar, tanto em relação ao deficiente, quanto à sua família, de maneiras diversas. Podem estar concentradas em uma única forma ou associadas entre si, podendo aparecer 
conjuntamente, alternando-se em alguns momentos e até mesmo contradizendo-se, em outros.

Independentemente da forma com que estas pessoas encontram para superar os seus conflitos e suas perdas, torna-se essencial perceber que tais artifícios podem contribuir para que elas possam se reerguer e enfrentar as suas dificuldades, assumindo os seus papéis sociais, profissionais e familiares, como qualquer ser humano dito "normal".

A função terapêutica, portanto, consiste em facilitar a elaboração de estratégias que visem o encadeamento de reações preservadoras da identidade, de forma que os meios em direção à reparação não sejam prejudiciais ao indivíduo e à sua reabilitação (ROCHA, 1999).

Fundamentalmente, busca-se o "empoderamento" da pessoa, ou seja, propiciar condições para que ela assuma o controle sobre sua própria vida, de maneira que possa estar tomando decisões por si mesma (TURNBULL e TURNBULL, 1997).

Alguns autores referem-se a uma reabilitação permeada pela concepção de um processo psicológico positivo. Este tipo de intervenção considera a relevância da percepção que o deficiente possui de sua condição. Neste enfoque, é muito importante que o deficiente possua uma compreensão de si mesmo que transcenda a sua patologia, como ressaltado anteriormente (SELIGMAN e CSIKSZENTMIHALYI, 2000).

Estes mesmos autores denominam tal compreensão de experiência subjetiva positiva. Tratase de maneiras positivas de conceber as suas vidas, chamando a atenção para aspectos como esperança, sabedoria, criatividade, coragem, espiritualidade, responsabilidade e perseverança (SELIGMAN M. e CSIKSZENTMIHALYI, 2000).

Vaillant (2000) aponta para a existência de uma adaptação marcada pelo que ele denomina de "defesas amadurecidas" (mature defenses). Este conceito relaciona-se com reações que se baseiam no altruísmo, sublimação, superação ou supressão, como também, na 
acomodação ou ajustamento. Este autor ressalta a importância da criatividade e busca de soluções práticas por parte da pessoa acometida por alguma situação adversa.

Entende-se, a partir destes pressupostos, que o acompanhamento terapêutico é um recurso fundamental para que a pessoa com lesão medular possa alcançar uma forma adequada de lidar com seus conflitos, para uma readaptação social e até mesmo para continuidade de um investimento no seu reestabelecimento físico, funcional e psicossocial.

\subsection{A Reabilitação e a pessoa com lesão medular}

\subsubsection{Definindo reabilitação e refletindo sobre sua prática}

Considerando-se a definição da OMS (1981), o termo reabilitação refere-se a todas as medidas utilizadas para reduzir os efeitos das afecções, bem como, aquelas necessárias para possibilitar a integração social da pessoa acometida por alguma patologia crônica. O reabilitar, portanto, no caso da pessoa com lesão medular, está relacionado com a existência de técnicas e profissionais adequados para que esta pessoa atinja, em algum nível, a recuperação de suas funções normais ou anteriores à lesão, além de proporcionar à mesma a possibilidade de aprender a conviver com a deficiência, de maneira que se torne apta a desenvolver todas as atividades necessárias ao seu dia-dia. Acredita-se, também, na necessidade reabilitacional de prover meios para que o reabilitando esteja totalmente inserido no ambiente em que vive.

De acordo com Novaes (1975), um dos principais objetivos do processo de reabilitação é o de restaurar no indivíduo a sua posição de elemento ativo e útil à sociedade, restabelecendo os sentimentos de autoconfiança e de independência perdidos, bem como, o de procurar obter um ótimo grau possível de ajustamento nos diversos setores das suas atividades. A reabilitação, portanto, requer atendimento dos problemas físicos e psicossociais de seu cliente. Para Rocha (1990), o objetivo da reabilitação é que o reabilitando se veja e se reconheça enquanto deficiente e, principalmente, enquanto sujeito de sua história de vida e como cidadão, exercendo seu papel social. 
Diversos fatores, portanto, fazem com que a prática reabilitacional se torne muito complexa e dinâmica, considerando que cada patologia assumirá uma manifestação clínica particular com dificuldades específicas ao contexto biopsicossocial apresentado por este ou aquele paciente $^{3}$. Tais dificuldades, por sua vez, apresentam diversificadas interações que devem ser abordadas a partir de um processo reabilitacional amplo, com a participação de uma equipe de trabalho multidisciplinar, como pode ser visualizado na figura 6 (LIPPINCOTT, 1988).

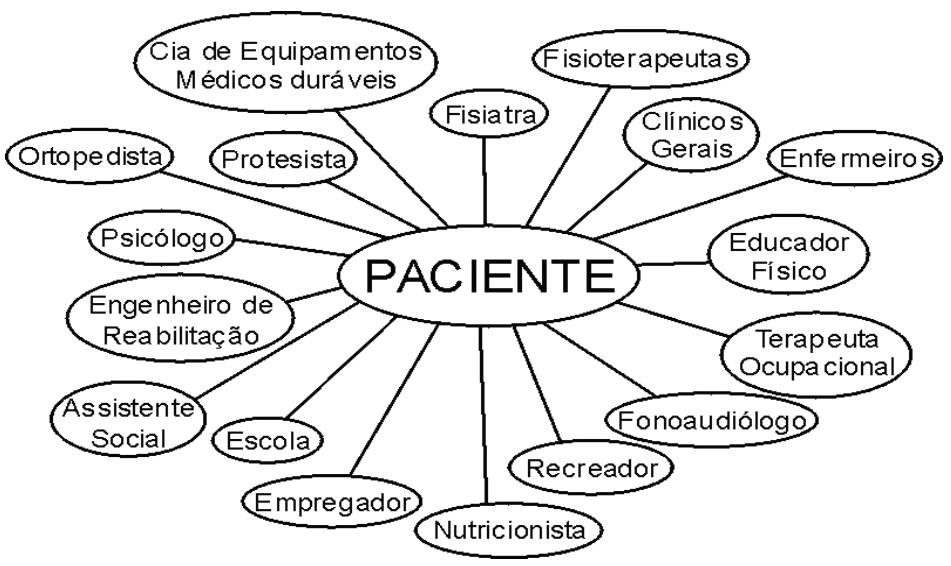

Figura 6. Múltiplos profissionais envolvidos no processo de reabilitação. Adaptado de LIPPINCOTT (1988).

A reabilitação voltada para pessoas que apresentam uma patologia como a lesão medular, necessita considerar a complexidade do quadro apresentado, para que possa prover a esta pessoa toda a assistência necessária, possibilitando um atendimento multidisciplinar que abranja sua dimensão biopsicossocial, de maneira que possa melhorar também a sua "Qualidade de Vida" (GONZALES, 2000).

De acordo com Mannuci, Ricca e Barciulli (1999), "Qualidade de Vida" se refere a uma satisfação global do indivíduo com a sua própria vida. Esta satisfação encontra-se baseada em seus valores, objetivos de vida, habilidades e necessidades. WARE (1995) cita alguns aspectos considerados importantes na aquisição de uma boa qualidade de vida, como por

\footnotetext{
${ }^{3}$ Optou-se pelo termo paciente, de acordo com a expressão utilizada pelos autores que fundamentam os tópicos que se relacionam com a reabilitação da pessoa com lesão medular.
} 
exemplo, a qualidade de moradia e vizinhança, satisfação no trabalho, bons relacionamentos familiares, de saúde e outros.

O conceito de "Qualidade de Vida", no entanto, é bastante subjetivo e relaciona-se com as características físicas, psicológicas e sócio-econômicas dos pacientes. Por este motivo, um processo de reabilitação que tenha como meta a "Qualidade de Vida" da pessoa com lesão medular, precisa considerar o que elas entendem por qualidade de vida, assim como o que elas esperam do seu processo reabilitacional (SANTOS,1989).

Em suma, a realização de um processo reabilitacional adequado encontra-se intimamente associada aos referenciais subjacentes a este ou aquele programa de reabilitação, mas também, com as formas como a pessoa acometida por uma patologia, encara sua situação pessoal e, logicamente, o seu processo reabilitacional. Em outras palavras, seria o significado da deficiência e da reabilitação em sua vida (NOVAES, 1975).

Entende-se, portanto, que o processo de reabilitação deve envolver os aspectos físicos, psicológicos e sociais do reabilitando, de maneira que tais aspectos não sejam abordados separadamente mas, sim, de forma a considerar a integridade da pessoa a que se propõe o tratamento reabilitacional. Por este motivo, a equipe multidisciplinar precisa estar incumbida de promover uma dinâmica interdisciplinar ${ }^{4}$, de forma que o atendimento oferecido ao paciente portador de uma patologia como a lesão medular não se torne fragmentado nas diversas áreas e atuações profisssionais.

Cabe ressaltar que a reabilitação, baseada no principio de "Qualidade de Vida", envolve não somente o espaço hospitalar ou reabilitacional, mas todos aqueles espaços em que ocorrem a vivência cotidiana da pessoa deficiente, o que engloba ações que incluem a preparação e conscientização daqueles que fazem parte de seu convívio, também incluindo neste contexto, a implantação de ações que tragam a esta pessoa, acometida por uma deficiência, uma percepção mais apurada de seus direitos e de sua capacidade de reivindicálos.

\footnotetext{
${ }^{4}$ Para maior esclarecimento dos conceitos "multidisciplinar" e "interdisciplinar", consultar Fazenda (1979).
} 
Ghirard (1999) aponta para a existência de dois focos reabilitacionais distintos e portanto, não integrados, que podem ser caracterizados como reabilitação institucional, baseada nos paradigmas médicos e focalizando a pessoa a ser reabilitada, com o objetivo de habilitá-la, de acordo com os padrões de eficiência social estabelecidos a priori e a reabilitação de paradigma social ou comunitária. Esta ultima tem como alvo de atuação os espaços onde ocorrem as relações sociais destas pessoas, com uma preocupação em resgatar a cidadania das pessoas acometidas por uma deficiência. Pode-se dizer que a reabilitação voltada para a adaptação da sociedade ao deficiente, baseada no paradigma social ou comunitário, aproxima-se do ideal revelado no movimento inclusivo iniciado no século passado (conforme caracterizado no item 1.2.1) e que abrange, de maneira especial, o âmbito da educação e mais especificamente o da educação especial.

Gonzales (2000) ressalta, a necessidade de um trabalho reabilitacional direcionado à pessoa com lesão medular, em que a equipe analise conjuntamente cada caso, desde o diagnóstico até as formas de evolução do seu quadro físico e psicossocial. Esta autora constatou que o diagnóstico é realizado de forma inadequada e danosa, tanto para o paciente quanto para a família, já que ele é executado de forma rápida e superficial, sem que sejam alcançados os objetivos propostos de preparo dos envolvidos para lidar com a patologia e suas posteriores repercussões físicas, psicológicas e socioeconômicas (TOMÁS e LLARAS, 1997).

A não realização de um tratamento com uma proposta de assistência integrada e interdisciplinar, ainda é um fato muito comum no modelo atual de prática assistencial encontrada em instituições de saúde, de uma forma geral. Observa-se, ao contrário, a participação de um médico com exclusiva responsabilidade por todo o processo de diagnóstico, tratamento e alta hospitalar. Constata-se uma atuação caracterizada por atendimentos parcelares, sem que haja uma compreensão desta pessoa e de sua dinâmica biopsicossocial, o que acaba por se tornar uma forma de intervenção inadequada pela inexistência da obtenção das melhoras a que objetivam as práticas reabilitacionais e de instituições de saúde em geral (GONZALES, 2000). 
Conforme anteriormente mencionado, várias são as dificuldades de ajustamento encontradas pelo deficiente e pelos seus familiares que se defrontam, de forma inesperada, com uma lesão medular, patologia que, por sua vez, produz efeitos físicos e fisiológicos considerados extremamente debilitantes. Entretanto, observa-se que o impacto psicossocial deste quadro e problemas associados a ele são minimamente reconhecidos nos programas de tratamento reabilitacionais (DEWIS,1989).

Gonzales (2000) entende que as dúvidas apresentadas pelos pacientes e familiares devem ser esclarecidas através de informações e orientações adequadas provindas de profissionais especializados na área. Não obstante, esta autora chama a atenção para a ausência deste tipo de intervenção nas instituições de assistência à pessoa com lesão medular. A autora considera a comunicação entre pacientes e profissionais de saúde um ponto de base para que estes profissionais possam dispensar a devida assistência às pessoas para as quais o tratamento é direcionado. Outro aspecto relevante, diz respeito ao vínculo estabelecido entre os profissionais de saúde que se encontram em contato direto com os mesmos, considerando-se a importância de uma relação com estes profissionais que propicie efeitos positivos sobre o reabilitando. Este fato torna-se essencial nestes casos, já que a pessoa com lesão medular passa por situações conflitivas e de muita insegurança, durante todo o seu processo reabilitacional. Observa-se que os profissionais de saúde, responsáveis pelos cuidados aos pacientes com lesão medular, muitas vezes, se sentem inseguros e despreparados frente à complexidade deste quadro, o que pode ser um fator complicador nos atendimentos voltados para pessoas que apresentam esta patologia.

Como é revelado em pesquisas realizadas por Ghirard (1999), o atendimento à lesão medular requer um grupo de profissionais que se proponha a realizar um trabalho bastante específico e qualificado, com uma assistência contínua, o que se torna um fator propiciador de situações ansiógenas e estressantes para os profissionais de saúde. Estes profissionais podem ainda, ao estabelecerem um relacionamento com as pessoas que atende, no caso as pessoas com lesão medular, compartilhar de alguma maneira, os estigmas e atribuições de descrédito que se destinam à pessoa com deficiência, conforme relata Goffman (1988, pg. 41), ao descrever os "estigmas de cortesia". As condições físicas e de infra-estrutura do 
ambiente onde é realizado o atendimento, também, são primordiais nestes casos e interferem significativamente no êxito do tratamento.

Embora, todos estes aspectos tenham relevância, observa-se que grande parte da produção teórica refere-se somente ao uso da tecnologia ou tratando de técnicas de manipulação corporal, uso de órteses, próteses e outros equipamentos de auxílio, quadros patológicos, entre outros (ROCHA, 1999).

\subsubsection{A interface entre tecnologia e reabilitação: história da prática reabilitacional}

A tecnologia aplicada à reabilitação tem sido cada vez mais bem sucedida no que se refere à realização de tratamentos voltados para a busca do restabelecimento total ou quase total de indivíduos atingidos pelas mais diversas patologias (LAVINE, ROBERTS e SMITH, 2002).

Esta abordagem reabilitacional, presente nos dias atuais, é tida como produto de um longo percurso histórico caracterizado por nuances que explicitam interesses políticos e sociais que marcaram as intervenções médicas em direção ao extermínio do que é considerado patológico.

Sabe-se que técnicas de exercícios e massagens com o propósito de aliviar dores, já eram realizadas em 1800 AC. No entanto, a idéia de uma restauração à condição orgânica anterior ao advento da doença, foi a base para a origem do conceito de reabilitação criado em 1844 por Franz Joseph Retter von Buss (OTERO,1988).

Mais precisamente no final do séc. XVII, com a revolução cartesiana, surge o conceito de reabilitação pautado nos princípios da especialização e racionalidade científica. Nesta época, iniciou-se uma filosofia médica baseada na medicalização das causas e dos problemas decorrentes da deficiência, determinando práticas reabilitacionais permeadas pelo saber científico (ROCHA, 1999). 
A interrelação entre a tecnologia e a medicina resultou dos avanços observados na área da biologia ocorridos no final do século XVIII e durante todo o século XIX, quando a doença passou a ser o alvo de intervenção e não o doente. Começaram a surgir as invenções voltadas para o diagnóstico e cirurgias médicas, como por exemplo, o estetoscópio, aparelhos para a tomada de pressão sanguínea e outros. Esta evolução denota um interesse cada vez maior no diagnóstico, classificação e controle das patologias. O saber médico e científico aparece como filosofia dominante no contexto da época. A ciência inserida na medicina passa a ter como princípio fundamental a normatização e correção do que é chamado de patológico. De acordo com esta filosofia, somente por meio da minimização do seu quadro patológico, o deficiente (ou doente), terá condições de se adequar e se integrar socialmente (ROCHA, 1999).

A partir da metade ao final do século XIX surgem as instituições de saúde onde eram implantadas tecnologias consideradas avançadas para a época e chamadas tecnologias de ponta. Hospitais ortopédicos para deficientes físicos, com ênfase para as cirurgias ortopédicas e construção de órteses e próteses foram implantados nesta época, em todo o mundo. As instituições reabilitacionais com caráter médico proliferaram, em especial, no fim do século XIX e início do século XX (ROCHA, 1999). A engenharia de reabilitação estava em evidência. Reuniões internacionais com especialistas em reabilitação se tornaram comuns nesta época marcando, desta forma, a influência exercida pelo saber científico (SILVA, 1998).

A engenharia de reabilitação tem sua origem na área de instrumentação médica e entrelaçase aos conhecimentos e atuação proporcionadas pela Engenharia Biomédica. As atividades em engenharia de reabilitação buscam desenvolver através dos conhecimentos das áreas de engenharia e da saúde, métodos, técnicas e instrumentos, que possam favorecer o atendimento e a recuperação de pessoas acometidas por alguma deficiência física. (ENGENHARIA DE REABILITAÇÃO, 2004). 
Para a aplicação dos recursos proporcionados por esta área de atuação, é necessária uma interação direta com os usuários desta tecnologia, já que se deve considerar seu quadro clínico, necessidades e evolução.

A intervenção em direção à reabilitação do deficiente físico, ocorrida no final do século XIX, trouxe como objetivo a capacitação para o trabalho e/ou atividades produtivas, conforme a visão social da época. A recuperação para o trabalho, tendo como meta o atendimento de veteranos de guerra, começou a se tornar uma das prioridades de países, tais como, EUA (Estados Unidos da América), Canadá e países da Europa, de uma forma geral. Surgem as profissões não médicas, consideradas essenciais no processo reabilitacional, tais como, terapeutas ocupacionais e fisioterapeutas. A Segunda Guerra trouxe uma nova política de incentivo às técnicas reabilitacionais e a recuperação para o deficiente sugerida neste período, deu ênfase ao aspecto motor e funcional, constituindo-se em uma reabilitação física e corporal que teve como meta uma aproximação desse corpo ao considerado "corpo perfeito", buscando-se a minimização da deficiência ou incapacidade funcional. Trata-se da lógica cientificista, implantada como prática médica também em países em desenvolvimento, como o Brasil, a Índia e a África do Sul. Técnicas cirúrgicas e de trabalho corporal eram utilizadas com caráter preventivo durante as décadas de 40 e 50 (ROCHA, 1999).

Nesse contexto, o conceito de equipe multiprofissional em reabilitação passa a se sobrepor a idéia de um médico generalista, sem que a função médica tenha perdido o seu valor e até a influência sobre tais profissionais, já que o mesmo é responsável pelo diagnóstico e encaminhamento do paciente dentro da instituição reabilitacional, até o seu possível desligamento ou alta (ROCHA, 1999).

O fim último das intervenções seria a preparação destas pessoas para torná-las novamente aptas a exercer suas atividades no mercado de trabalho. A reabilitação, a partir da década de 70, do século XX, passa a fazer parte dos planos políticos nacionais de planejamento para a saúde da população (MAZAS e MATAMORO, 1991). Entre as práticas utilizadas, destacam-se os métodos e sistemas eletrônicos, biomecânicos e de computação, como 
afirmado pelo grupo de estudo sobre capacitação médica da OPAS (Organización Panamericana de la Salud - Organização Pan-Americana de Saúde) (OPAS, 1988).

Nos dias atuais, a junção entre as áreas biológicas e exatas tem possibilitado experimentos que permitem, em um futuro próximo, uma reparação total de problemas cardíacos, além da criação de células vivas, sangue artificial e tecidos humanos em ambientes laboratoriais. Com a interface entre cérebro e máquina, pacientes tornam-se habilitados a controlar membros artificiais, através de redes neurais e são criados implantes cocleares e tentativas para restaurar a visão com o uso de eletrodos que ativam a retina, o nervo óptico e o próprio córtex cerebral, realizadas por cientistas especializados em ramos da bioengenharia. Vale ressaltar que, além destes, vários outros estudos encontram-se em andamento com o objetivo de sanar os problemas trazidos pela deficiência ou ao menos amenizá-los (LAVINE, ROBERTS e SMITH, 2002). Os avanços da bioengenharia e da tecnologia médica podem ser observados na figura 7 . 


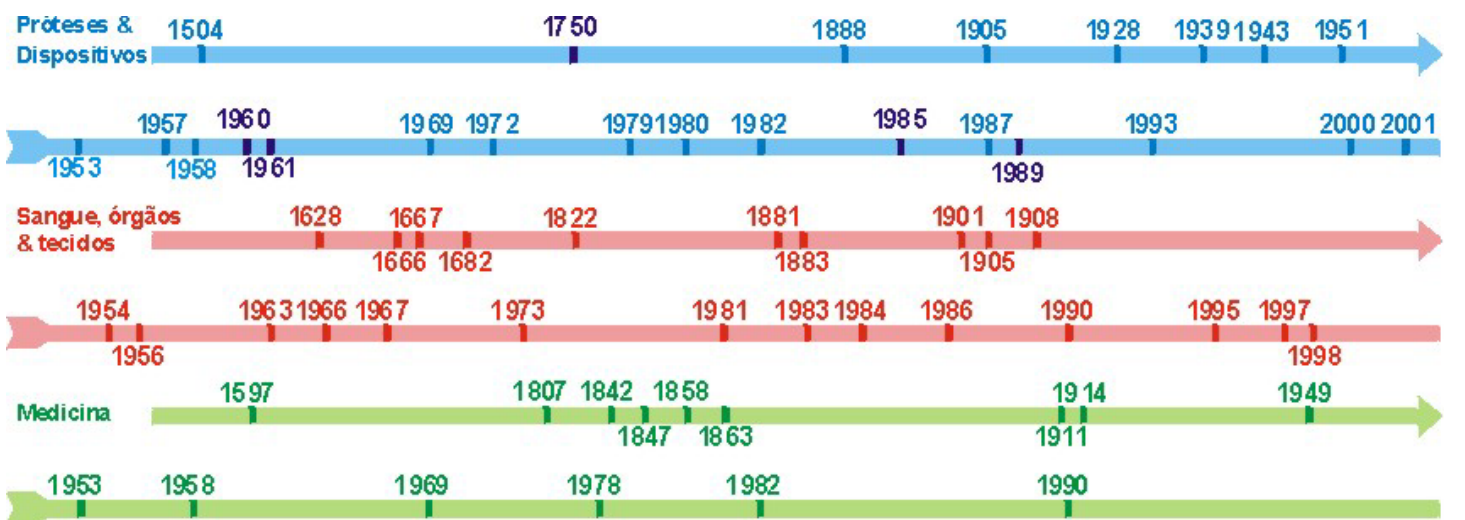

1504 Mão protética em aço com as juntas dos dedos flexíveis

1597 Reconstrução do nariz por enxerto de tecido

1628 Desenvolvimento inicial de uma teoria sobre o sistema circulatório

1666 Transfusão de sangue entre dois cachorros

1697 Transfusão de sangue entre um carneiro e um humano

1682 Reparo de um crânio humano com ossos de um crânio de cachorro

1750 Um violinista que teve seus músculos do braço paralisados devido a um AVC, foi estimulado eletricamente com uma fonte estática. Após dois anos com este tratamento voltou a tocar violino

1807 Desenvolvimento de um endoscópio para cirurgias minimamente invasivas

1822 Primeiro auto-enxerto com pele fresca realizado com sucesso

1842 - 1847 Primeiras descobertas e demonstrações de compostos com propriedades anestésicas

1847 Introdução do amalgama prateado para obturações dentarias

1858 Publicação do primeiro volume do Gray's Anatomy

1853 Introdução de técnicas de cirurgias anti-sépticas

1881 Primeiro enxerto temporário de pele

1883 Desenvolvimento da solução de Ringer para manter tecidos vivos fora do corpo

1888 Primeiras noticias do uso de lentes de contato para corrigir a visão

1901 Identificação dos diferentes grupos sanguíneas

1905 e 1906 Primeiras noticias de transplantes de córnea

1905 Descoberta das técnicas para crescimento de células de tecidos in vitro

1905 Transfusão direta de sangue entre humanos feita com sucesso

1905 Primeiros esforços para substituição do quadril por uma prótese 1908 Primeiros esforços para cirurgia de restabelecimento do joelho (usando um cadáver para substituição da parte)

1911 Injeção de parafina para tratar a paralisia das pregas vocais

1914 Citrato identificado como anticoagulante, usado para estocagem de sangue

1928 Desenvolvimento de um pulmão de aço para o tratamento de vitimas da pólio

1939 Introdução das lentes (plásticas) de contato rígidas

1943 Desenvolvimento da maquina de diálise de rins

1949 Identificação do entrave do sistema imunológico na rejeição de tecidos

1951 Primeira válvula cardíaca artificial implantada

1953 Desenvolvimento de uma maquina de coração/pulmão

1953 Demonstração da tolerância imunológica adquirida de transplantes oriundos de terceiros

1954 Transplante de rins entre gêmeos idênticos

1956 Primeiro transplante de medula óssea realizado com sucesso

1956 Primeiro transplante de pâncreas realizado com sucesso

1957 Primeiro implante coclear desenvolvido
1958 Primeiras tentativas de desenvolvimento de um marcapasso implantável

1958 Identificação da importância do sistema de histocompatibilidade para combinação de tecidos

1960 Primeira demonstração do "ficar em pé" através da EENM em pacientes com lesão medular -realizado por Kantrowitz

1961 Primeiro sistema FES portátil para extremidades inferiores em pacientes com lesões dos neurônios motores superiores, desenvolvido por Liberson et all, com pacientes hemiplégicos

1963 Primeiro transplante de fígado

1966 Primeiro transplante de pâncreas realizado com sucesso

1967 Primeiro transplante de coração realizado com sucesso (o paciente sobreviveu 18 dias)

1969 Primeira cerâmica biocompatível desenvolvida que podia ser unida ao colágeno e o osso

1969 Foi implantado em um humano um coração artificial total como medida provisória

1972 Testado um projeto moderno de aço/polímero para uma junta de quadril

1973 Transplante com sucesso de medula óssea entre paciente e doador sem parentesco

1978 O imunossupressor Ciclosporina é introduzido

1979 Primeiro implante auditivo tronco cerebral

1980 Primeiro implante coclear de simples canal em uma criança com sucesso

1981 Uma ponte de nervos periféricos e implantada em um rato adulto com uma lesão medular

1982 Insulina criada através de engenharia genética e comercialmente disponível (a primeira droga desenvolvida com esta técnica)

1982 Implante do Jarvik-7, um coração artificial total e permanente

1983 Primeiro transplante com sucesso de um único pulmão

1984 Um bebe fae recebe um coração de um bugio e sobrevive 20 dias

1985 Primeiro trabalho com a EENM visando a realização da marcha de um paciente lesado medular (paraplégico completo) em laboratório em Glasgow, Escócia

1986 Primeiro transplante com sucesso de um par de pulmões

1987 Primeiro uso clinico de um dispositivo bioartificial de fígado 1989 Início do Programa de EENM no HC da UNICAMP, DOT/FCM, Unidade de Reabilitação do Aparelho Locomotor

1990 O imunossupressor FK506 torna-se disponível

1990 O Primeiro transplante de pulmão de um doador vivo

1993 O FDA aprova o dispositivo de assistência do ventrículo esquerdo como uma ponte para o transplante de coração

1995 Jeff Getty recebe um transplante de medula óssea de um bugio

1997 Transplante de neurônios de porco em pacientes com o mal de Parkinson

1998 Transplante de mão humana

1998 Transplante total de laringe

2000 Implante de um protótipo de pâncreas artificial

2001 Implante do AbioCor, um coração artificial total permanente autocontido

Figura 7. Linha do tempo dos avanços da bioengenharia e da tecnologia médica. Adaptado de Lavine, Roberts e Smith (2002). 
1.3.3. Fundamentando a utilização de recursos elétricos nos tratamentos de saúde: um breve resumo histórico

As primeiras tentativas de tratamento por meio da utilização de recursos elétricos ocorreram no séc. XIV, logo após a invenção do gerador de eletricidade estática (figura 8), quando com a aproximação dos pacientes ao condutor destes geradores, era gerada uma corrente elétrica entre os corpos em contato. Tal tipo de intervenção era comumente utilizado em casos de paralisia (CHERNOVIZ, 1890).

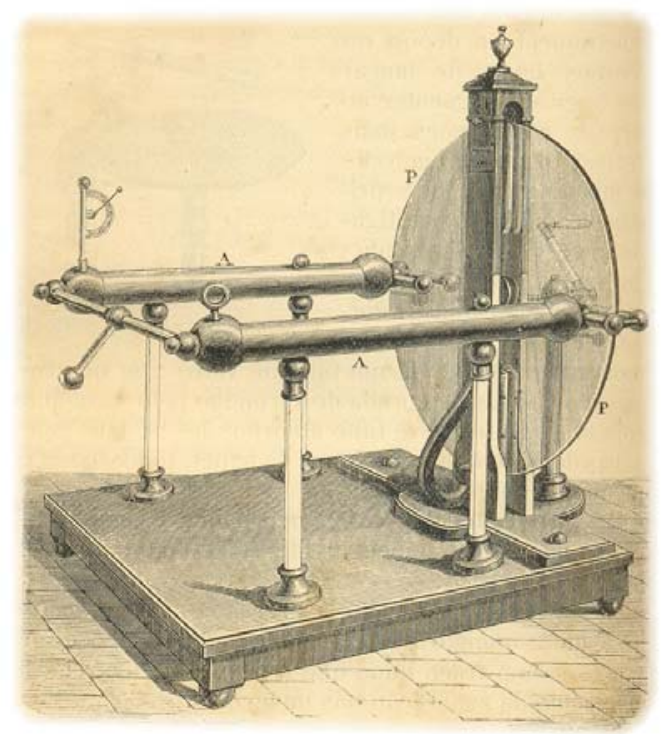

Figura 8. Gerador de eletricidade estática do século XIV (CHERNOVIZ, 1890).

No entanto, sabe-se que os primeiros ensaios de aplicação da eletricidade com caráter terapêutico foram realizados por Humboldt, no final do século XVIII, quando este cientista, no exercício de experimentos elétricos em um pássaro paralisado nos seus movimentos, consegue colocá-lo de pé e batendo as asas, segundo Chernoviz (1890).

Já no fim do século XIX, com a evolução dos conhecimentos sobre a eletricidade, foi possível a criação de uma máquina que gerava uma corrente elétrica por indução. Esta máquina tinha como objetivo a passagem da corrente elétrica a um membro afetado por paralisia, através de dois eletrodos, como pode ser visualizado nas figuras 9 e 10. 

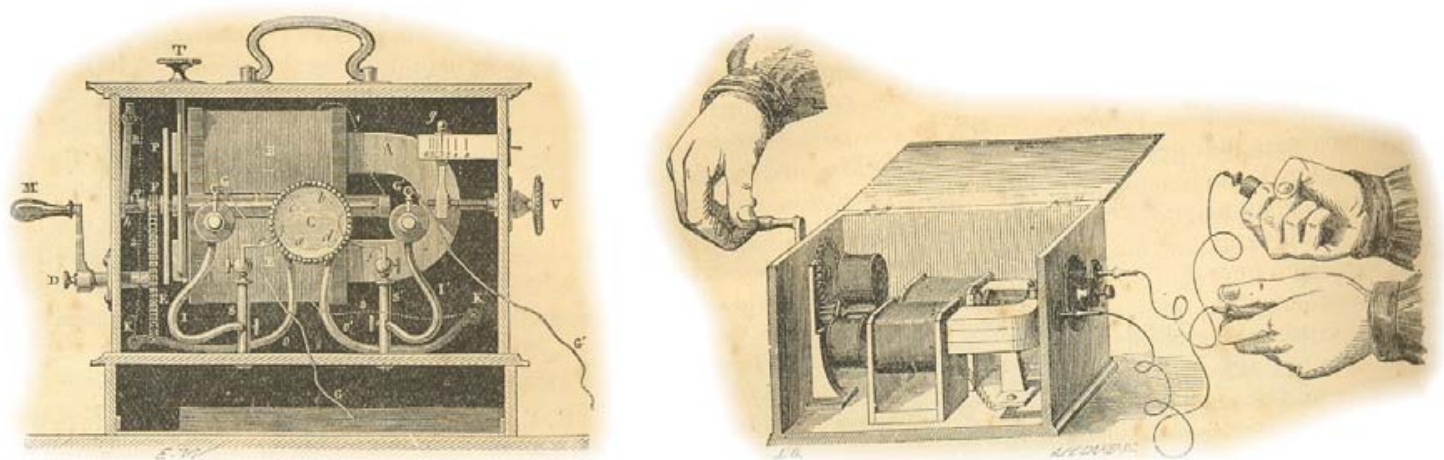

Figura 9. Geradores de corrente elétrica por indução com interrupção, do século XIX. À esquerda: Aparelho magneto-elétrico de Breton e à direita o de Gaiffe (CHERNOVIZ, 1890).

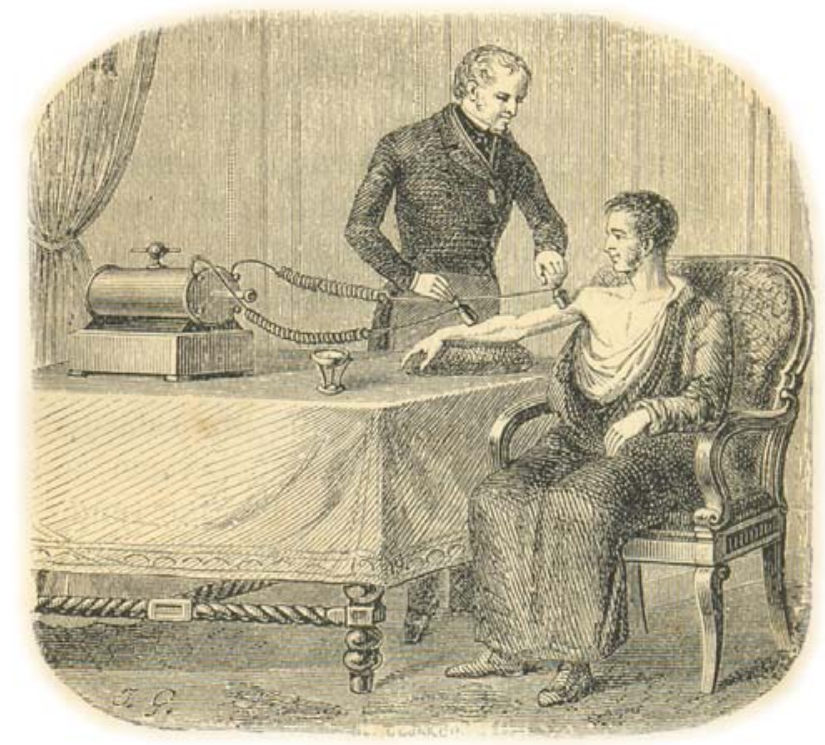

Figura 10. Aplicação da eletricidade na paralisia do braço, segundo Chernoviz (1890).

Com base nestas informações, pode-se constatar que a utilização de correntes elétricas com fins terapêuticos, já era prevista como possibilidade desde que se deram a criação e popularização dos equipamentos elétricos.

Nos dias atuais, a eletricidade é considerada um recurso importante no diagnóstico (ex: eletrocardiograma) e tratamento de diversas patologias, estando presente em um grande número de intervenções fisioterápicas e de bioengenharia. 
A engenharia biomédica e de reabilitação também vem possibilitando a utilização de aparelhos eletrônicos para facilitar a superação de obstáculos físicos e orgânicos de pessoas acometidas por patologias diversas. No caso do deficiente físico, mais particularmente, a pessoa com lesão medular, a aplicação da Estimulação Elétrica Neuromuscular (EENM), restaurando movimentos por meio de aparelhos de estimulação e eletrodos, que podem ser de superfície ou implantados, vêm sendo desenvolvida e aprofundada em estudos realizados por engenheiros, técnicos da área de ciências exatas e profissionais da área de saúde.

\subsubsection{A Reabilitação por meio da EENM}

Como já dito anteriormente, uma das técnicas que se tem mostrado muito eficiente para a reabilitação dos movimentos dos membros afetados pela paralisia gerada por uma lesão medular é a EENM (ORTOLAN et al, 2001). Na literatura, freqüentemente, os termos FNS (Functional Neuromuscular Stimulation - Estimulação Neuromuscular Funcional), FES (Functional Electrical Stimulation - Estimulação Elétrica Funcional) e NMES (Neuromuscular Electrical Stimulation - Estimulação Elétrica Neuromuscular) são usados, no lugar de "Estimulação Elétrica Neuromuscular aplicada para a estimulação dos neurônios motores inferiores". O objetivo da EENM funcional é obter contrações imediatas de músculos esqueléticos, induzindo movimentos funcionais (QUINTERN, 1998).

Esta técnica prevê a ativação de fibras nervosas contidas em grupos musculares específicos. $\mathrm{O}$ princípio neurofisiológico subjacente a este procedimento refere-se à liberação de potenciais de ação em partes do sistema nervoso que não se encontram prejudicadas pela lesão, através de estimulação elétrica externa, de forma a substituir os sinais neurais (QUINTERN,1998). Com este procedimento, efetivou-se a possibilidade da realização de movimentos funcionais antes impossíveis em consequência da lesão medular. A EENM também é usada visando a reeducação muscular, prevenção de atrofias, redução temporária da espasticidade e redução das contraturas e edemas (ORTOLAN et al, 2001, SELKOWITZ, 1985). 
Um dos primeiros relatos do uso da EENM é datado por volta de 1750 quando um violinista, que teve seus músculos do braço paralisados devido a um acidente vascular cerebral (AVC), foi estimulado eletricamente com uma fonte estática semelhante às mostradas nas figuras 8 e 9. Após dois anos sob este tratamento voltou a tocar violino (MCNEAL, 1977). O primeiro trabalho com a EENM que tornou possível a realização da marcha de um paciente com lesão medular em laboratório, foi desenvolvido no ano de 1985, em Glasgow, Escócia. Conforme mencionado, além de ser utilizado fisioterapicamente, a EENM pode ser aplicada, com o intuito de restabelecer os movimentos de membros paralisados (ANDREWS et. al., 1986; CLIQUET, 1989, 1988).

A EENM é realizada com a aplicação de eletrodos e pode ser feita usando métodos invasivos ou não-invasivos. No método invasivo são utilizados eletrodos implantados cirurgicamente no organismo, podendo estarem estabelecidos intramuscularmente, com a utilização simultânea de fios elétricos percutâneos (MARSOLAIS E KOBETIC, 1987) ou por eletrodos suturados diretamente na inervação motora (PECKHAM, 1987). A estimulação realizada transcutâneamente, ou seja, através de eletrodos localizados na superfície da pele, é considerada não invasiva (ANDREWS e BAXENDALE, 1988; BAJD, KRALJ e TURK, 1982; BAJD et. al, 1983; GRAUPE, 1989; JAEGER, YARKONY e SMITH, 1989; KRALJ et. al, 1983; YARKONY et al.,1990)

Os métodos invasivos não são muito interessantes do ponto de vista operacional, devido a uma série de inconveniências, tais como, possíveis quebras dos eletrodos e infecções causadas pela abertura na qual é feita a introdução dos mesmos. Tratando-se da EENM feita com eletrodos de superfície, como é o caso da pesquisa realizada pela equipe do professor Dr. Alberto Cliquet Jr. ${ }^{5}$, no Departamento de Ortopedia da Faculdade de Ciências Médicas, da UNICAMP (Universidade de Campinas), Programa de EENM, os eletrodos são colocados na superfície da pele e o sinal induz linhas de campo dentro do membro, de forma que os íons de sódio, localizados externamente à membrana do nervo motor, sofram um influxo súbito para dentro do nervo, gerando o potencial de ação (ORTOLAN et al, 2001). Esta perturbação se propaga pelo axônio até a fenda sináptica e o músculo, então, é

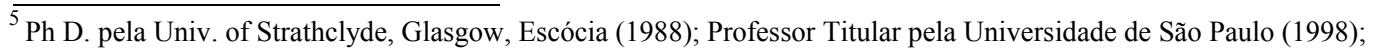
Professor Titular e Chefe de Departamento de Ortopedia e Traumatologia da Faculdade de Ciências Médicas da UNICAMP.
} 
contraído (KOVÀCS, Z. 1997). Sendo assim, executando a estimulação em músculos/nervos específicos, de maneira controlada e cíclica e tomando certas precauções, é possível realizar a marcha em pacientes com lesão medular em laboratório. Usando esta técnica, o paciente muda novamente sua condição e passa a realizar, de forma artificial, os movimentos que havia perdido com a lesão (CLIQUET, 1993; QUEVEDO, PATLA e CLIQUET, 1997, QUEVEDO et. al., 1997; SEPULVEDA e CLIQUET, 1996; SEPULVEDA, GRANAT e CLIQUET, 1998).

Além da restauração artificial dos movimentos responsáveis pela deambulação, observa-se a partir da aplicação de EENM alguns efeitos terapêuticos muito importantes, como por exemplo: reversão da osteoporose; restauração de alguns movimentos voluntários; significativa recuperação da sensibilidade; geração de padrão rítmico e restauração do controle motor (CLIQUET, 1988). De acordo com Cliquet (2003), estes resultados encontram-se relacionados com a ativação de centros nervosos. Esta ativação, por sua vez, ocorre devido a produção dos impulsos aferentes por meio do estímulo elétrico, incitados durante o treinamento da marcha com a EENM.

Cliquet (2003) afirma que a neuroplasticidade ${ }^{6}$ constitui-se, também, como um efeito da aplicação da tecnologia junto à reabilitação de pessoas com déficits neurológicos que atingem a função motora. Acredita-se que, com a ocorrência de estímulos advindos do meio ambiente, o organismo tende a se readaptar, buscando maneiras para que as funções neurológicas atingidas sejam novamente ativadas, através da elaboração de novas conexões nervosas (RIBEIRO, 1995).

A maneira como o Programa de EENM, vem sendo utilizado na Universidade Estadual de Campinas, encontra-se descrita no próximo item.

\footnotetext{
${ }^{6}$ Forma de reorganização das conexões celulares do cérebro para reabilitar uma área cerebral comprometida na sua função. Trata-se de uma tentativa do sistema nervoso, de formar novas conexões ou recuperar conexões perdidas (OLIVEIRA, SALINA e ANNUNCIATO, 2002).
} 


\subsubsection{O Programa de EENM}

Os critérios utilizados para a seleção de pessoas que se candidatam a participar deste programa baseiam-se, principalmente, na condição fisiológica das mesmas, de forma que em todo o processo de triagem possam ser detectadas características individuais importantes para a viabilização deste tipo de tratamento. Estas características dizem respeito ao tempo de instalação da lesão, a existência ou não de comprometimento de toda a enervação periférica, grau de estabelecimento de osteoporose, grau de comprometimento da medula (lesão medular completa ou incompleta) e nível medular da lesão. Para a obtenção de todas estas informações é realizada por profissionais da área de saúde, uma Avaliação Clínica completa, composta de entrevista inicial para organização de uma ficha ou histórico médico do paciente, avaliação eletrofisiológica (exame de potencial evocado, eletromiografia, exame cardiovascular - eletrocardiograma), avaliação física realizada pelo protocolo da Associação Americana de Lesões Medulares (ASIA), densiometria óssea e consumo energético.

Os pacientes selecionados para participar do referido programa devem ter sofrido a lesão medular há pelo menos um ano. Isto se deve à necessidade de que estas pessoas já tenham passado por todas as fases fisiológicas comuns a um trauma medular (fase de choque medular, retorno da atividade medular reflexa e fase de ajustamento), de forma que as mesmas tenham alcançado o seu patamar máximo de recuperação pós-lesão, ou seja, que tenham efetuado todas as aquisições neurofisiológicas possíveis, até então, dadas as características de sua lesão.

A integridade das inervações periféricas é indispensável a este tipo de reabilitação, já que a mesma irá permitir a realização da contração muscular, a partir de um estímulo elétrico aplicado no nervo periférico, como acontece neste programa (BENTON et. al, 1979). A estimulação elétrica tem como objetivo evocar um potencial de ação. Este estímulo é aplicado de forma que o potencial de ação seja produzido em nervos periféricos e/ou músculos específicos, com o intuito de produzir uma contração muscular e a possibilidade de que a pessoa, através de uma série de estímulos com freqüência e duração apropriadas, possa realizar movimentos considerados funcionais, artificialmente (GREVE. et. al. 2001). 
Terminada a triagem, o paciente que se encontra em condições físicas adequadas para iniciar a EENM, submeter-se-á a todas as fases exigidas para a realização do mesmo.

Em uma primeira fase, o paciente passará por um período de estimulação voltado para o recondicionamento muscular. Este estágio é realizado na posição sentada, ocorrendo uma ou duas vezes na semana, tendo a aplicação a duração de 10 a 15 minutos, durante aproximadamente três meses, variando de acordo com as reações fisiológicas e musculares de cada paciente e da região estimulada.

Concluída a fase de adaptação e condicionamento muscular será executada a transferência desta pessoa, da posição sentada para a de pé, na qual o estímulo é novamente aplicado, agora na postura chamada de ortostatismo (posição ortostática). Nesta fase, a pessoa com lesão medular deverá exercer uma hiperextensão de quadril e extensão do joelho. Para atingir esta posição, ele contará com o apoio de um andador convencional e, se necessário, obterá o auxílio de um profissional. O objetivo deste treinamento é alcançado quando a pessoa com lesão medular atinge um tempo superior a dez minutos na posição ortostática, continuamente ou com breves intervalos para repouso (GREVE et. al., 2001); passada esta fase, iniciará o treinamento da deambulação, em que serão utilizados, além do estimulador, equipamentos auxiliares de locomoção, como por exemplo, um andador, alterando flexão/extensão de quadril, joelho e tornozelo, controladamente (marcha).

A pesquisa realizada por meio deste programa tem como meta a consecução de um trabalho multidisciplinar, realizado com a participação de uma equipe composta por engenheiros, neurologistas, ortopedistas, urologistas, fisioterapeutas, terapeuta ocupacional e educador físico, com vistas a obtenção de um melhor índice de qualidade de vida, para a pessoa com lesão medular. 


\subsubsection{Efeitos psicossociais da EENM em pessoas com lesão medular.}

Embora sejam comuns as especulações sobre os benefícios psicossociais advindos da utilização de EENM, poucos são os estudos que focalizam este aspecto (BROW, 1996).

Aliando-se o fator psicológico com a reabilitação, algumas vantagens são observadas em relação ao tratamento com a EENM. A primeira que surge é o restabelecimento de uma postura corporal que possibilita a pessoa com lesão medular, a ficar no mesmo nível das pessoas não deficientes. É possível com a EENM trazer de volta a esta pessoa o sentimento de pertencimento, recuperando sua auto-imagem, já que se encontra agora na mesma posição postural que outras pessoas não lesadas. Isto faz com que ela se sinta igual e não mais em uma posição inferiorizada e desfavorecida em relação aos outros, como pode ser observado na figura 11.
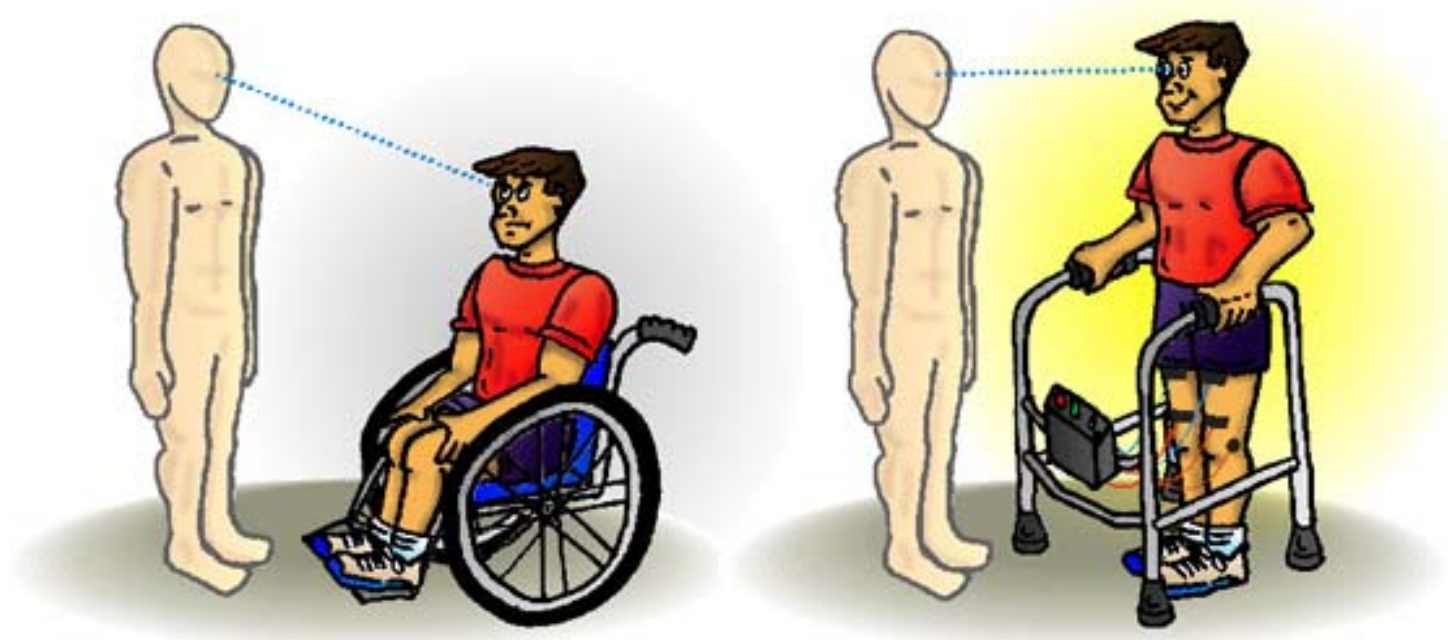

Figura 11. Restabelecimento da postura corporal.

Segundo Brow (1996), a utilização de EENM por pessoas acometidas por lesão medular, traduz-se, principalmente, em uma possibilidade maior de independência e autonomia para as realizações de atividades de vida diária.

A aplicação deste tratamento resulta também, nestas pessoas, um investimento maior em sua recuperação. Há necessariamente mudanças em relação ao seu comportamento perante 
a vida. A crença na recuperação traz novas perspectivas e as possibilidades de ajuste social tornam-se maiores. Verifica-se que a aplicação da EENM em uma pessoa com lesão medular influencia diretamente a auto-confiança, os estados de humor e auto-imagem, reduzindo, assim, a depressão e ansiedade (BROW,1996).

Entretanto, expectativa irreal, e ansiedade em grandes proporções, podem gerar um quadro ameaçador ao tratamento proposto, já que tais sentimentos, se pouco trabalhados, podem levar o paciente a um posterior desânimo, ou se tornarem geradores de uma ansiedade ainda maior, causando uma descarga emocional inesperada, dificultando, assim, o êxito do tratamento. Bradley (1994) em estudos que comparavam resultados alcançados com o uso de EENM e expectativas quanto a este tratamento, detectou um aumento da depressão e hostilidade em pessoas com expectativas não-realísticas para o programa de EENM. Segundo esta autora, faz-se necessário que elas estejam devidamente orientadas sobre os efeitos e possibilidades de um tratamento como este, de maneira adequada e consciente. É necessário, também, que o paciente submetido a EENM consiga adquirir um equilíbrio emocional para lidar com seus limites e possibilidades e até mesmo com as incertezas em relação ao seu prognóstico (BRADLEY, 1994).

O desconhecimento associado a sentimentos, tais como, a angústia causada pela incerteza e pela ansiedade, faz com que eles apresentem uma inconstância em relação ao tratamento e a sua aceitação. Tal inconstância torna-se fator de risco ao prosseguimento da intervenção, já que se traduz em um maior prolongamento das ações propostas por este tratamento. A preparação destas pessoas, com atendimento terapêutico as mesmas, seria uma maneira de evitar o desgaste causado por esses comportamentos, o que facilitaria em muito a otimização deste tipo de reabilitação (BRADLEY, 1994).

É comum observar que nem sempre a reabilitação destas pessoas com a EENM é bem sucedida, já que muitas delas abandonam o tratamento, principalmente, por motivos sócioeconômicos, limitando, portanto, a sua aplicabilidade (TRIOLO, KOBETIC E BETZ, 1996). 
A expectativa em relação a resultados imediatos é um fator também importante que pode comprometer a aceitação deste tipo de tratamento. A figura 12 ilustra efeitos diferenciados a este tratamento, marcados pela satisfação ou não satisfação com o mesmo. Estas reações ao tratamento encontram-se em grande parte, influenciadas pelas expectativas apresentadas pela pessoa com lesão medular.Triolo, Kobetic e Betz (1996) apontam para alguns aspectos sobre a utilização de EENM que poderiam, de alguma forma, limitar os efeitos de sua aplicação, como por exemplo, o gasto excessivo de energia, o grau de confiabilidade do paciente e as variadas respostas fisiológicas apresentadas.

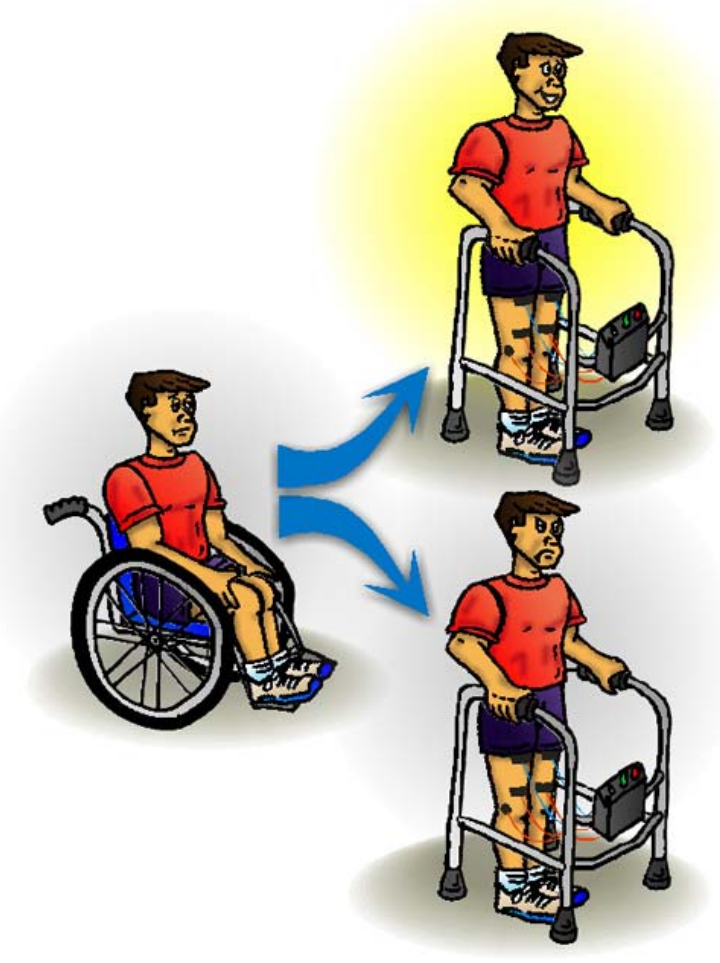

Figura 12. Efeitos psicossociais da EENM: motivações e expectativas

O problema da expectativa em relação ao tratamento, neste caso, pode também ser exacerbado pela família da pessoa com lesão medular, que, em casos específicos, chega a esperar um pronto resultado e rápida reabilitação. Este é um ponto que deve ser abordado, pois os familiares abdicam de várias atividades para acompanhar os pacientes no tratamento e influenciam em muito os resultados. A participação da família, neste processo, é uma variável que se torna extremamente importante para o sucesso ou fracasso deste tratamento. 
É importante ressaltar que passam pelo ambulatório da UNICAMP, aproximadamente 40 a 60 pacientes, entre paraplégicos e tetraplégicos, a uma razão média de 50\% entre eles, durante um ou dois dias por semana (entre segunda-feira e sábado) e existe um grande número de pessoas na fila de espera para o tratamento. Isto sugere que quanto mais fatores auxiliarem no processo de reabilitação, mais pessoas poderão ter acesso a este tipo de tratamento.

\subsubsection{Fundamentos para uma reabilitação biopsicossocial}

Para a construção de uma prática fundamentada nas necessidades da pessoa com lesão medular, torna-se necessário compreender qual o impacto das intervenções reabilitacionais sobre estas pessoas, assim como a maneira em que as mesmas vivenciam, percebem e o que esperam do seu processo reabilitacional. Qualquer intervenção reabilitacional que tenha como meta um atendimento ao deficiente necessita, em primeiro lugar, considerar as suas necessidades e interesses, tendo como origem das informações o próprio reabilitando e não as concepções formadas por outras fontes que não as situadas no próprio objeto da ação (ALMEIDA, 1993).

Considerando a reabilitação como um processo, faz-se interessante que a mesma possa ser analisada em seus princípios e filosofia de sustentação, quando percebidas em suas metas e objetivos. Em contextos reabilitacionais diferenciados e até mesmo dentro de um contexto comum, podem ser visualizadas formas diferentes de conceber e tratar o "ser deficiente". Isto se deve aos conceitos de deficiência implícitos e explícitos nas práticas educacionais e reabilitacionais (PAULA, 1993).

Por este motivo, torna-se imprescindível que haja um entendimento entre as áreas de conhecimento e profissionais afins envolvidos direta ou indiretamente com o paciente. $\mathrm{O}$ tratamento reabilitacional deve englobar a pessoa como um todo e não somente a sua "deficiência". Compreende-la na sua complexidade consiste em percebê-la como um ser biopsicossocial, partindo do princípio que características físicas/fisiológicas, psíquicas e 
sociais constituem-se interligadas como em uma rede de interações e não devem ser consideradas separadamente, já que elas se comunicam o tempo inteiro na vida de qualquer pessoa.

É importante, também, observar que se tratando de pessoas com lesão medular, os sentimentos envolvidos tornam-se preponderantes para o seu tratamento, já que a experiência que cada um assume ao se tornar portador de uma deficiência física incapacitante é indescritível, diferenciada e somente possível de ser compreendida em toda sua dimensão quando contextualizada na vida desta pessoa. Tal experiência está relacionada a perdas que assumem dimensões diferenciadas. Por esse motivo, torna-se praticamente impossível dar a conhecer, com clareza, as seqüelas emocionais e quais as conseqüências as mesmas podem trazer para este tipo de tratamento em específico, sem que esta pessoa encontre um espaço de expressão, assimilação e elaboração de seus sentimentos.

É igualmente importante que a pessoa em reabilitação, seja contemplada na sua condição de ser social, já que é na sua vivência social cotidiana que se expressam e se definem, concretamente, os seus limites e possibilidades de vida (PAULA, 1993).

Todas estas questões remetem a forma como estas pessoas, com lesão medular, percebem o seu papel como deficiente em todas as interações que estabelecem. A maneira encontrada para lidar com as suas limitações no seu dia-dia, assim como o seu processo de ajustamento a esta situação refletirão permanentemente em suas ações como ser social. Trata-se de como esta pessoa se percebe e se coloca perante o meio em que convive e como reage aos estigmas ou estereótipos que esta sociedade muitas vezes lhe impõe como verdades préconcebidas.

Carter (2001) aponta três aspectos essenciais para a análise e compreensão das condições que podem levar a pessoa com lesão medular a apresentar reações complicadoras para sua reabilitação, tais como, ansiedade, raiva internalizada, hostilidade e depressão. Estes aspectos dizem respeito à percepção que estas pessoas possuem de si mesmas, do meio 
social e do futuro. Segundo este autor, a lesão medular pode ser responsável pelo estabelecimento de percepções inadequadas de si, do meio social e do futuro.

A percepção inadequada de si mesmo deve estar relacionada com a perda de suas funções motoras e, portanto, de uma imagem social de adequação e normalidade. A dependência e a visão social diferenciada ou estigmatizada, ocorridas com o advento da deficiência, podem gerar sentimentos de inadequação e até conflitos relacionais.

De acordo com Carter (2001), a interação constante com ambientes hospitalares e reabilitacionais, ocorrida a partir do advento de uma lesão medular, pode gerar uma percepção de seu ambiente, associada com sentimentos de privação, frustração, além da impressão de que se encontra doente ou incapacitado.

Carter (2001) também afirma que a concepção de que a condição de lesado medular, com suas limitações funcionais, contitui-se em um estado irreversível, assim como as incertezas relacionadas ao seu quadro clínico (WERNER, 1994), contribuem para uma expectativa de futuro predominantemente negativa e, portanto, inadequada.

\section{Hipóteses e Objetivos desta Pesquisa}

Tendo por base os entendimentos e informações supracitadas questiona-se, quais as características psicossociais apresentadas pelos usuários da EENM e quais destas assumem o papel de facilitadoras e dificultadoras de seu processo reabilitacional, inspirado em Carter (2001) e quais efeitos da tecnologia aplicada através deste tratamento na vida destas pessoas. Outra questão refere-se à possibilidade de diferenças significativas na percepção, concepção e expectativas, quanto a este tipo de reabilitação em pessoas que participam deste programa em períodos de tempo diversificados.

Partiu-se da hipótese de que pessoas com lesão medular submetidas a um processo de reabilitação baseado na perspectiva de uma recuperação total ou parcial de suas funções 
motoras, como é o caso da EENM, podem apresentar um autoconceito, percepção social, e, principalmente, uma expectativa para o futuro, considerados positivos. Acredita-se, também, que a confiança neste tipo de reabilitação e seus benefícios apresentados, podem estar gerando uma maior disponibilidade e dedicação do deficiente no seu processo reabilitacional.

Outra hipótese levantada diz respeito à necessidade de uma reabilitação que englobe estas pessoas na sua totalidade biopsicossocial.

Os objetivos desta pesquisa consistem em identificar e analisar as características psicossociais gerais dos pacientes envolvidos com a EENM funcional; avaliar os efeitos obtidos com a reabilitação através da EENM, segundo a visão dos próprios participantes, tendo em vista os reflexos deste tratamento em suas atividades diárias, nos seus relacionamentos familiares e sociais e na maneira destas pessoas se perceberem. Buscou-se também, avaliar a importância da reabilitação e participação neste programa. A consecução dos objetivos citados acima, poderá contribuir como subsídio para identificação das principais necessidades destas pessoas e condução de um tratamento psicoterápico adequado ao quadro caracterológico dos pacientes com lesão medular, submetidos a EENM, possibilitando, desta forma, a realização de um processo reabilitacional que contemple a pessoa com lesão medular em sua dinâmica biopsicossocial.

\section{Método}

\subsection{Participantes.}

Foi selecionada uma amostra de 12 participantes e dividida em dois grupos distintos, que variavam de acordo com o tempo de tratamento através da EENM. O primeiro grupo (Grupo 1) foi constituído por 6 (seis) pessoas que estavam sob este tratamento há mais de um ano e o segundo grupo (Grupo 2) composto por 6 (seis) pessoas que estavam participando do programa em período máximo de um ano, a fim de apreender aspectos 
similares e divergentes entre estes dois grupos, no que se refere as percepções, concepções e expectativas quanto a reabilitação por meio da EENM .Estas pessoas foram também selecionadas de acordo com o seu interesse em participar desta pesquisa. A população pertencente a estes grupos, foi identificada em relação ao tipo e causa da lesão, a época em que ocorreu a lesão medular, a faixa etária, estado civil, grau de escolaridade, profissão/ocupação e renda aproximada, como pode ser visualizado nas tabelas 1 e 2 , a seguir:

Tabela 1. Caracterização dos Participantes - parte 1.

\begin{tabular}{|c|c|c|c|c|c|c|c|}
\hline PESSOA & SEXO & IDADE & ESCOLARIDADE & ESTUDANTE & $\begin{array}{l}\text { ESTADO } \\
\text { CIVIL }\end{array}$ & $\begin{array}{l}\text { NÍVEL/CAUSA } \\
\text { LESÃO }\end{array}$ & $\begin{array}{c}\text { TEMPO } \\
\text { TRATAM. }\end{array}$ \\
\hline 1 & M & 27 & $3^{\circ}$ grau incompleto & não & solteiro & $\begin{array}{c}\text { T9 } \\
\text { arma de fogo }\end{array}$ & 2,5 anos \\
\hline 2 & $\mathrm{~F}$ & 22 & $3^{\circ}$ grau & não & solteira & $\begin{array}{c}\text { T4 } \\
\text { acidente de carro }\end{array}$ & 4 anos \\
\hline 3 & M & 30 & $2^{\circ}$ grau & $\operatorname{sim}$ & solteiro & $\begin{array}{c}\text { T5 } \\
\text { acidente de carro }\end{array}$ & 4 anos \\
\hline 4 & M & 35 & $3^{\circ}$ grau & não & casado & $\begin{array}{c}\text { T6/T7 } \\
\text { acidente de carro }\end{array}$ & 2,5 anos \\
\hline 5 & M & 44 & $2^{\circ}$ grau & não & casado & $\begin{array}{l}\text { T12/L1 } \\
\text { acidente de carro }\end{array}$ & 1 ano e 2 meses \\
\hline 6 & M & 32 & $2^{\circ}$ grau & não & solteiro & $\begin{array}{c}\text { T10 } \\
\text { arma de fogo }\end{array}$ & 1,5 anos \\
\hline 7 & $\mathrm{~F}$ & 37 & $2^{\circ}$ grau incompleto & não & viúva & $\begin{array}{l}\text { T5/T6 } \\
\text { acidente de carro }\end{array}$ & 9 meses \\
\hline 8 & M & 36 & $2^{\circ}$ grau incompleto & não & casado & $\begin{array}{c}\mathrm{C} 6 / \mathrm{C} 7 \\
\text { acidente de carro }\end{array}$ & 7 meses \\
\hline 9 & $\mathrm{~F}$ & 38 & $3^{\circ}$ grau incompleto & não & solteira & $\begin{array}{l}\text { T5 - acidente de } \\
\text { carro }\end{array}$ & 6 meses \\
\hline 10 & M & 29 & $1^{\circ}$ grau incompleto & $\operatorname{sim}$ & solteiro & $\begin{array}{l}\mathrm{T} 12 \text { - acidente de } \\
\text { trabalho }\end{array}$ & 4 meses \\
\hline 11 & M & 34 & $1^{\circ}$ grau & não & casado & C5/C6 - queda & 1,5 meses \\
\hline 12 & M & 43 & $3^{\circ}$ grau & não & solteiro & $\begin{array}{c}\mathrm{C} 7 \\
\text { tumor }\end{array}$ & 3 meses \\
\hline
\end{tabular}


Tabela 2. Caracterização dos Participantes - parte 2.

\begin{tabular}{|c|c|c|c|c|c|}
\hline PESSOA & $\begin{array}{l}\text { RELIGIÃO/PRÁTICA } \\
\text { ESPIRITUAL }\end{array}$ & $\begin{array}{c}\text { ATIVIDADE } \\
\text { REMUNERADA }\end{array}$ & $\begin{array}{l}\text { PROFISSÃO/ } \\
\text { OCUPAÇÃOO }\end{array}$ & $\begin{array}{c}\text { RENDA } \\
(\text { SM*) }\end{array}$ & $\begin{array}{c}\text { IDADE QUE } \\
\text { OCORREU A } \\
\text { LESÃO } \\
\end{array}$ \\
\hline 1 & católico/não praticante & não/aposentado & $\begin{array}{l}\text { trabalho esporádico - } \\
\text { comércio }\end{array}$ & $3 \mathrm{SM}$ & 24 \\
\hline 2 & católica & Em casa -digitação & $\begin{array}{c}\text { Administradora } \\
\text { desempregada }\end{array}$ & - & 9 \\
\hline 3 & católico & $\begin{array}{l}\text { em casa (autônomo) e } \\
\text { fora de casa (emprego) }\end{array}$ & $\begin{array}{l}\text { Técnico em } \\
\text { inform/operador } \\
\text { microcomputad. }\end{array}$ & $3 \mathrm{SM}$ & 14 \\
\hline 4 & católico & fora de casa(emprego) & $\begin{array}{l}\text { Administrador/ } \\
\text { bancário }\end{array}$ & $8,5 \mathrm{SM}$ & 31 \\
\hline 5 & evangélico & não/reformado & $\begin{array}{l}\text { Mecânico/militar } \\
\text { reformado }\end{array}$ & $11 \mathrm{SM}$ & 34 \\
\hline 6 & evangélico & em casa & $\begin{array}{l}\text { Bombeiro/ } \\
\text { reformado }\end{array}$ & $5 \mathrm{SM}$ & 28 \\
\hline 7 & católica & não/aposentada & $\begin{array}{c}\text { Chefe administrativa/ } \\
\text { aposentada }\end{array}$ & $10 \mathrm{SM}$ & 27 \\
\hline 8 & católico & não/aposentado & $\begin{array}{l}\text { Bar man/ } \\
\text { aposentado }\end{array}$ & $2,5 \mathrm{SM}$ & 34 \\
\hline 9 & Espírita/não praticante & não/aposentada & $\begin{array}{c}\text { Bancária/ } \\
\text { aposentada }\end{array}$ & $2,5 \mathrm{SM}$ & 27 \\
\hline 10 & evangélico & não/aposentado & $\begin{array}{l}\text { Operador de } \\
\text { motoserra/ } \\
\text { aposentado }\end{array}$ & $1 \mathrm{SM}$ & 25 \\
\hline 11 & evangélico & não/auxílio doença & Vigilante/parado & 4 a $5 \mathrm{SM}$ & 33 \\
\hline 12 & não tem & fora de casa/ escritório & advogado & $14 \mathrm{SM}$ & 38 \\
\hline
\end{tabular}

Como mostram as tabelas 1 e 2, percebe-se nesta população a predominância de pessoas do sexo masculino, havendo apenas três do sexo feminino. A idade dos participantes variou de 22 a 44 anos, sendo a idade média de 33,9 anos, constituindo-se, portanto, de uma população que pode ser considerada jovem. Três terminaram o terceiro grau e dois não terminaram. Três deles concluíram o segundo grau, e dois não completaram. O primeiro grau aparece relativo apenas a uma das pessoas, sendo que uma delas relatou não ter concluído o primeiro grau. Estes dados indicam um bom nível de escolaridade, visto a pequena quantidade de pessoas que não iniciaram o segundo grau e o número razoável daquelas que chegaram a cursar o terceiro grau. A maior parte destas pessoas não se encontra mais estudando, fato este que já era esperado devido à faixa etária apresentada. São na sua maioria solteiros, já que apenas quatro apresentaram vínculos matrimoniais e uma participante viúva. A religião predominante é a católica (6), sendo que um não praticante. Logo após vem a evangélica com quatro pessoas, todas elas praticantes. Uma delas revelou ser espírita não praticante e outra relatou não seguir uma religião. Sete delas afirmaram não exercer alguma atividade remunerada, sendo que todas estas pessoas 
inseridas nesta categoria, encontravam-se no momento na condição de aposentados ou reformados. Duas trabalhavam em casa e três delas possuíam vínculo empregatício ou algum trabalho remunerado fora de casa. Quanto à remuneração, em salários mínimos, foi observada uma variação de 2,5 a 3 - (4 pessoas); 4 a 8,5 - (3 pessoas); 10 a 14 - (2 pessoas), uma pessoa tendo renda mensal de um salário mínimo e uma não apresentado renda, já que na condição de desempregada. Foi constatada uma média de 5,4 SM. Para a idade de ocorrência da lesão, pode-se perceber que, embora haja uma grande ampliação com indivíduos lesionados entre nove e trinta e oito anos, os números predominantes demonstraram uma maior incidência nas idades entre 20 e 35 anos. Quanto ao nível e causa da lesão foi constatado maior número de pessoas atingidas na região torácica (9), portanto, paraplégicos e para a cervical uma menor incidência (3), formada pela população de tetraplégicos. A causa mais notória foi por acidente automobilístico (7), aparecendo, também, arma de fogo (2) e outras causas menos freqüentes, a saber, acidente de trabalho, queda e tumor.

Destaca-se que estas pessoas não foram selecionadas de acordo com o nível e grau de sua lesão, o que faz com que o seu quadro clínico tenha sido um fator completamente aleatório no que diz respeito a esta pesquisa.

Para a análise das características psicossociais destes participantes foi considerada a amostra total, composta de 12 usuários regulares do programa de EENM desenvolvido no HC da UNICAMP. Para a análise das concepções e expectativas em relação à EENM, os participantes foram divididos em dois grupos, conforme o tempo de tratamento através da EENM.

A composição da referida amostra e distribuição dos subgrupos, para análise dos aspectos relativos ao tratamento com a EENM, foram realizadas através da verificação dos prontuários de pacientes inscritos no programa de EENM. Fazem parte do Grupo 1 as Pessoas 1 a 6, e do Grupo 2 participaram as Pessoas 7 a 12. 
Alguns familiares destes participantes, selecionados aleatoriamente, de acordo com o seu interesse em participar desta pesquisa, também contribuíram como informantes e encontram-se devidamente caracterizados na tabela 3, de acordo com o grau de parentesco com a pessoa com lesão medular; idade; ocupação e profissão; renda aproximada (em número de salários mínimos) e nível de escolaridade. Os familiares das pessoas 4, 6, 9, 10, 11 , e 12, não se encontram incluídos como informantes desta pesquisa, visto não terem feito parte do grupo de familiares formado para coleta de dados.

Tabela 3. Caracterização dos familiares.

\begin{tabular}{|c|c|c|c|c|c|}
\hline \multirow[b]{2}{*}{$\begin{array}{c}\text { PESSOA COM } \\
\text { LESÃO } \\
\text { MEDULAR }\end{array}$} & \multicolumn{5}{|c|}{ FAMILIAR } \\
\hline & $\begin{array}{c}\text { grau de } \\
\text { parentesco }\end{array}$ & Idade & $\begin{array}{l}\text { Ocupação/ } \\
\text { Profissão }\end{array}$ & $\begin{array}{l}\text { Renda } \\
\text { Familiar* } \\
\text { (SM) }\end{array}$ & Nível de escolaridade \\
\hline Pessoa 1 & mãe & 49 & dona de casa & $15 \mathrm{SM}$ & $1^{\circ}$ grau incompleto \\
\hline Pessoa 2 & mãe & 41 & $\begin{array}{l}\text { vendedora } \\
\text { autônoma }\end{array}$ & $\begin{array}{c}\text { não } \\
\text { respondeu }\end{array}$ & $1^{\circ}$ grau completo \\
\hline Pessoa 3 & pai & 62 & mecânico & $5 \mathrm{SM}$ & $2^{\circ}$ grau incompleto \\
\hline Pessoa 3 & mãe & 51 & $\begin{array}{c}\text { doméstica/do } \\
\text { na de casa }\end{array}$ & $5 \mathrm{SM}$ & $1^{\circ}$ grau completo \\
\hline Pessoa 5 & esposa & 41 & cabeleireira & $15 \mathrm{SM}$ & $3^{\circ}$ grau incompleto \\
\hline Pessoa 7 & mãe & 65 & dona de casa & 7, $7 \mathrm{SM}$ & $1^{\circ}$ grau incompleto \\
\hline Pessoa 8 & esposa & 37 & comerciante & $2,5 \mathrm{SM}$ & $2^{\circ}$ grau completo \\
\hline
\end{tabular}

*SM: Salários Mínimos

De acordo com a tabela 3, a maior parte destes familiares eram mães (4), logo depois esposas (2) e um único pai. Desta forma, pode-se constatar, neste grupo, a grande predominância de mulheres, já que apenas um dos participantes é do sexo masculino. A faixa etária situava-se entre 37 e 65 anos, sendo de 49,4 anos, a idade média do grupo. Também é possível dizer que se tratavam de pessoas de meia idade, das quais duas delas completaram o primeiro grau, uma o segundo grau e apenas com uma delas chegando ao terceiro grau, porém não terminando sua formação. Vale ressaltar a ocorrência de duas pessoas com $1^{\circ}$ grau incompleto e uma com o $2^{\circ}$ grau incompleto. É interessante observar que um dos familiares alegou exercer sua ocupação como autônomo e, a maior parte, totalizando um número de quatro, exerciam profissões diversificadas, sendo que três deles se auto-denominaram donas de casa. A renda familiar destas pessoas (exceto a que não respondeu) variava entre dois e meio a quinze salários mínimos, sendo a renda média de 9 
salários mínimos. Em relação a este dado, é importante observar a omissão de um dos informantes que se negou a responder esta questão, alegando não possuir uma renda fixa.

\subsection{Contexto do Estudo.}

Todo o processo de coleta de dados ocorreu no Hospital das Clínicas da UNICAMP, junto ao Departamento de Ortopedia da Faculdade de Ciências Médicas, onde é realizado o Programa de EENM funcional. Esta pesquisa foi devidamente aprovada pelo Comitê de Ética desta instituição, conforme parecer apropriado (anexo B).

O contato entre a pesquisadora e os participantes se deu pessoalmente, ocorrendo no próprio hospital onde a pesquisa foi realizada, onde eles se faziam presentes toda semana, com o objetivo de realizar seu tratamento reabilitacional e, no caso das famílias, acompanhar o membro familiar deficiente.

\subsection{Recursos Materiais.}

O material e instrumentos utilizados para a coleta de dados foram os seguintes:

- 01 gravador portátil convencional

- fitas cassetes

- roteiro de entrevista para caracterização da pessoa com lesão medular (Apêndice A)

- formulário para caracterização dos familiares (Apêndice B)

\subsection{Procedimento para Coleta de Dados.}

Para a consecução dos objetivos da pesquisa foram utilizados os seguintes instrumentos de coleta de dados: roteiro de entrevista para caracterização da pessoa com lesão medular e formulário para caracterização dos familiares. Também foram coletados dados através de reuniões semanais (cinco reuniões ao todo) com os grupos de familiares. 
Através da entrevista, pretendeu-se captar os aspectos conceituais, motivacionais, opinativos e expectativas dos participantes em relação à lesão medular e a reabilitação de uma forma geral, bem como, sua percepção sobre os efeitos fisiológicos e psicossociais relacionados ao tratamento com a EENM. Desta forma, algumas características psicossociais dos participantes envolvidos, bem como, suas principais necessidades, puderam ser identificadas.

Esta pesquisa se baseia na análise da experiência subjetiva de seus participantes. Este enfoque, de inspiração fenomenológica, reconhece a pessoa no seu contexto de "ser histórico", como "ser no mundo" e que se relaciona com este mundo, modificando-o ao mesmo tempo que modificado por ele. Enfoca-se para isso, a percepção e significado de aspectos relacionados a vivência dos participantes, de acordo com o que se mostrou consciente durante os momentos de entrevista (MERLEAU - PONTY, 1980, 1990).

Elaborou-se o "roteiro de entrevista para caracterização da pessoa com lesão medular", contendo 49 questões. As questões que constituíram os primeiros tópicos (17), eram referentes aos "dados de identificação" e ao "histórico da lesão medular", contribuindo para a caracterização inicial dos participantes, conforme pode ser visualizado nas tabelas 1 e 2 , anteriormente apresentadas. As demais questões foram distribuídas em 05 blocos temáticos a saber: percepções em relação à lesão medular (9 questões); trabalho/estudos e relacionamento social (8 questões); aspecto familiar (3 questões); reabilitação (4 questões); concepções e expectativas em relação à EENM (8 questões) - ver apêndice A.

Os conteúdos das questões foram elaborados com base na análise da temática proposta, conforme revisão bibliográfica explicitada na introdução.

Foram introduzidas questões abertas a fim de permitir maior elaboração, aprofundamento e liberdade de expressão dos participantes, sempre de acordo com os objetivos da pesquisa. Também permitiu esclarecer dúvidas que se fizessem necessárias, propiciando flexibilidade no que tange à consideração dos diversos aspectos que se relacionavam ao fenômeno 
estudado.Trata-se de um levantamento, por se utilizar de uma interrogação direta às pessoas sobre a sua percepção acerca dos comportamentos que se deseja conhecer.

O roteiro de entrevista foi submetido a um estudo piloto, com três pessoas que apresentavam características correspondentes às especificações dos futuros participantes, para que fossem avaliados aspectos referentes à sua extensão, clareza de linguagem, seqüência, abrangência e condições de utilização, visando reformulações que permitissem sua melhoria.

As entrevistas foram individuais e ocorreram através de um único encontro entre cada paciente e a pesquisadora que perdurou um tempo aproximado de 50 minutos. Os encontros foram marcados previamente e realizados no próprio ambiente onde o paciente já se encontrava para execução de seu tratamento, através da EENM (HC da UNICAMP), em uma sala privativa, onde não houvesse riscos de interrupções externas. Inicialmente foram esclarecidos os objetivos da pesquisa e suas possíveis implicações. Garantiu-se aos participantes, que sua identidade seria preservada. Caso concordassem, solicitava-se a assinatura de um Termo de Consentimento Esclarecido (Apêndice C)

Anteriormente ao início da entrevista, solicitou-se a permissão para o uso da gravador, tendo em vista a necessidade de preservar a integridade das informações colhidas. Entretanto, advertiu-se que as gravações poderiam ser interrompidas, a qualquer momento, caso o participante julgasse apropriado. Tendo sido obtida a permissão, iniciava-se a entrevista propriamente dita. Caso contrário, utilizar-se-ia o registro cursivo das respostas oferecidas pelos participantes.

Convém ressaltar que todos os participantes consentiram na utilização do gravador, sem interrupções, como recurso para obtenção dos registros.

O entrevistado iniciava relatando sobre a sua vida diária e a pesquisadora assumia o papel de ouvinte, somente interrompendo suas falas quando eram necessários esclarecimentos ou 
aprofundamento das respostas quando se tratava de novas indagações, até que todas as questões estivessem sido respondidas na sua totalidade.

Com relação ao "formulário para caracterização dos familiares", foram abordados os seguintes aspectos: grau de parentesco; idade; ocupação/profissão; renda familiar e nível de escolaridade. Tal formulário consistiu de 14 questões, cujas informações obtidas podem ser visualizadas na tabela 3 , anteriormente apresentada.

\subsubsection{Breve descrição da dinâmica das sessões de grupo com os familiares}

As sessões de grupo realizadas com os familiares dos pacientes se deram a partir da formação de dois grupos, constituídos por três a cinco participantes e escolhidos aleatoriamente, de acordo com o seu interesse em participar da pesquisa. Um grupo era formado pelos familiares presentes durante os atendimentos ocorridos pela manhã e outro pelos que se encontravam no horário da tarde.

Nas sessões de grupo eram discutidos assuntos de seu interesse. As falas ocorreram espontaneamente e sem algum tipo de direcionamento por parte da pesquisadora, a não ser para obtenção de dados importantes quanto a algumas informações pessoais necessárias à caracterização destes informantes. A dinâmica própria em que os grupos se constituíam mostravam um bom relacionamento e entrosamento entre os envolvidos. Era incentivada a participação de todos que estavam ali pelos próprios membros do grupo, já que, quando um membro terminava seu relato, havia a espera e, muitas vezes, um questionamento para que um outro membro do grupo opinasse e compartilhasse a sua própria experiência.

As reuniões eram semanais, com duração aproximada de duas horas. Convém esclarecer que a formação destes grupos ocorreu a partir de uma demanda dos próprios familiares,no momento em que a pesquisa foi proposta, indicada por uma necessidade verbalizada à pesquisadora pelos mesmos. 
A partir destes encontros foi possível identificar fatores ambientais relevantes; experiências intra-familiares; percepção que os familiares possuíam sobre os entrevistados e sua lesão medular; mudanças observadas após a ocorrência do trauma e, também, após o início do tratamento com a EENM. Considerou-se igualmente, a expectativa da família em relação a pessoa com lesão medular.

\subsection{Procedimento para análise dos dados.}

Os dados obtidos tanto nas entrevistas quanto nas sessões de grupo com os familiares, foram posteriormente analisados, com base na abordagem qualitativa da análise de conteúdo, preconizada por Bardin (1977). De acordo com a referida autora, tal análise deve buscar uma interpretação controlada, baseada na dedução: a inferência. Deste modo, oscilase entre "o rigor da objetividade e a fecundidade da subjetividade" (p. 09).

A partir da análise das questões do "roteiro de entrevista para caracterização da pessoa com lesão medular", foram identificados blocos temáticos pertinentes ao problema abordado, conforme anteriormente mencionado. Cada bloco temático apresentou subtemas que se encontram apresentados através de tabelas, na secção resultados e discussão.

Cada entrevista foi transcrita na íntegra e, após várias leituras, destacaram-se os conteúdos das falas relacionados aos blocos temáticos sistematizados.

Procedeu-se à análise de conteúdo de todas as falas, procurando-se identificar os seus aspectos comuns e divergentes, passando-se a classificá-los, qualificá-los e quantificá-los nos referidos blocos. É importante ressaltar que a quantificação foi somente utilizada com o intuito de sistematizar os dados qualitativos apresentados.

Desta forma, os resultados obtidos para todos os blocos temáticos referem-se ao produto desta análise, que considerou os referidos aspectos nas respostas dos participantes. É importante ressaltar que as análises realizadas focalizaram as respostas dadas às questões 
do roteiro, considerando que um participante poderia apresentar mais de uma resposta no transcorrer de seu depoimento. Os resultados referentes às falas dos familiares, abrangem somente o que foi evidenciado durante as reuniões de grupo, ocorrendo, muitas vezes, uma maior proeminência de depoimentos de alguns familiares/informantes em específico.

\subsection{Forma de Apresentação dos Resultados.}

Os resultados serão apresentados sob a forma descritiva e por meio de tabelas, nas quais encontram-se inseridas as respostas analisadas e a quantificação da freqüência com que as mesmas aparecem (representadas pela letra "F" no cabeçalho da tabela), bem como, a identificação da pessoa a quem se referem as respostas, representadas pela letra "P". As respostas aparecem nas referidas tabelas, de acordo com a sua freqüência, por ordem decrescente. A discussão se dará paralelamente à apresentação dos resultados, de forma a facilitar a compreensão e assimilação pelo leitor. Alguns relatos são apresentados com o objetivo de exemplificar e esclarecer a discussão e encontram-se descritas como declaradas pelos participantes e informantes desta pesquisa, respeitando-se a linguagem própria de cada um. As considerações finais virão logo a seguir e terão a incumbência de finalizar e complementar os resultados obtidos. Elas também terão como objetivo, trazer novos questionamentos sobre o tema abordado e sugestões para a continuidade de estudos que se fizerem necessários.

\section{Resultados e Discussão}

\subsection{Bloco Temático 1: Percepções em relação à Lesão Medular}

A tabela 4 contempla o modo com que os entrevistados descreveram os eventos que os levaram a adquirir a lesão medular, com a finalidade de elucidar as suas principais impressões e percepções relacionadas a este fato. 
Tabela 4. Percepção sobre os eventos causadores da lesão medular.

\begin{tabular}{ccc}
\hline PERCEPÇÃ O & $\mathbf{P}$ & $\mathbf{F}$ \\
\hline \hline descreve efeitos e sensações corporais & $2,3,4,5,6,7,8,9,10,11,12$ & 11 \\
descreve reações das pessoas & $2,3,5,6,7,8,9,10,11$ & 09 \\
descreve e avalia a prestação de socorro inadequada & $2,5,7,10$ & 04 \\
descreve e avalia o atendimento hospitalar & & 03 \\
pós-lesão inadequado & $4,7,8$ & 03 \\
descreve vivência de um estado intermediário & $3,7,8$ & 02 \\
entre a vida e a morte & 3,6 & 02 \\
descreve reações em função de crenças religiosas & 5,8 & 02 \\
descreve sentimento de aflição. Ex: "é agoniante" (P5) & 7,11 & 01 \\
descreve sua primeira reação & 4 & 01 \\
descreve e avalia a prestação de socorro adequada & 6 & 01 \\
descreve a prestação de socorro (resgate) & 1 & 39 \\
apenas descreve a situação & & Total \\
\hline \hline
\end{tabular}

A presença da tragicidade encontra-se proeminente em todas as situações que levaram estas pessoas a adquirirem tal patologia. Sem dúvida, estes acontecimentos aparecem como um marco na vida destas pessoas. Os efeitos e sensações corporais são mais enfatizados pelos entrevistados ao relatarem estes eventos e são compreendidos por eles como conseqüências do advento abrupto de uma deficiência debilitante. O relato, abaixo, exemplifica esta evidência:

Pessoa 3: eu não tinha movimento nenhum do pescoço pra baixo, a única coisa que eu movimentava era male male a boca, que eu tava com a língua toda inchada do acidente, da batida que eu levei e o olho, mas o resto do corpo era praticamente morto, tava morto, $e$ eu não tinha movimentos.

A ênfase nos efeitos e sensações corporais aponta para o valor dado às modificações corporais induzidas a partir de acontecimentos como estes. Neste momento, eles vivenciam uma experiência incomum e assustadora, que se reflete em uma perda de estabilidade e reconhecimento corporal. Com as conseqüências orgânicas da deficiência já estabelecidas, o controle dos impulsos e respostas corporais (integridade psico-física) é bastante minimizado, impondo-lhes diversas limitações (SCHERB, 1998). Observou-se, também, uma evidência nas reações das pessoas que se encontravam por perto (4 relatos), como pode ser contemplado no seguinte relato: 
Pessoa 5: Aí os colegas que me atenderam disseram que eu tive parada cardíaca, me fizeram massagem cardíaca, respiração boca a boca... quando eu voltei a primeira coisa que eu falei era que era pra massagear a perna que eu não tava sentindo a perna. Aí o colega no desespero pegou minha perna e ficou encolhendo, esticando, encolhendo, esticando, igual eles fazem no campo de futebol quando você toma uma pancada

Entre tais reações, pode-se ressaltar a forma como foram socorridos logo após o ocorrido. Eles foram socorridos pela própria vizinhança, por pessoas que se encontravam por perto no momento do acidente ou por uma equipe de resgate especializada. A maneira como foram resgatados aparece como algo muito significativo, já que entendem que este fato, somado ao atendimento hospitalar pós-lesão, podem ou não ser responsáveis por um prejuízo maior em suas funções corporais. Esta questão pode ser constatada nos seguintes relatos:

Pessoa 2: Eu sofri um acidente de carro há treze anos atrás e no meu acidente o que me prejudicou foi na hora do socorro, que foram vizinhos que me socorreram de forma inadequada. Em vez de chamar o corpo de bombeiros, não, os próprios vizinhos me levaram até o hospital. Nisso minha coluna mexeu de todos os lados, de todas as formas e tive a lesão. Dai eu fiz a cirurgia, tive uma lesão total e fiquei em coma também porque eu bati a cabeça, mas foram quatro ou cinco dias de coma, passei mais vinte e um dias no hospital, quatro meses deitada.

Pessoa 7: Aí de lá me transferiram pra outro hospital, aí liberaram a visita, porque eu já ia entrar em óbito, não fizeram nada! Aí a enfermeira falou pro meu pai: Tira sua filha daqui porque ela vai morrer!

Neste relato observa-se, ainda, a vivência de um estado intermediário entre a vida e a morte. A crença religiosa é justificada pela descrição de reações que são atribuídas a uma intervenção divina e encontra-se presente no depoimento abaixo: 
Pessoa 6: Falei: Doutora, calma que eu estou bem! Doutora eu tô bem, calma que eu tô bem, Deus tá aqui, como Deus também está aqui. Pressão arterial normal, nível de consciência normal, pulsação normal, tudo normal.

A referência a uma prestação de socorro adequada ou somente a sua descrição, aparecem com menor freqüência em seus relatos. As justificativas dadas para a sua sobrevivência, para o advento da lesão medular e para a recuperação de algumas funções corporais encontram-se dispostas na tabela 5 .

Tabela 5. Justificativas dadas para a sobrevivência, para o advento da lesão e recuperação de

\begin{tabular}{|c|c|c|c|c|}
\hline \multicolumn{2}{|c|}{ JUSTIFICATIVA } & CONTEÚDO & $\mathbf{P}$ & $\mathbf{F}$ \\
\hline \multirow{8}{*}{ 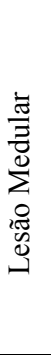 } & \multirow{4}{*}{ Fatalista } & destino (algo que tinha que ocorrer) & 6,7 & 02 \\
\hline & & castigo (precisava para aprender) & 9 & 01 \\
\hline & & vontade divina & 11 & 01 \\
\hline & & & Subtotal & 04 \\
\hline & \multirow{3}{*}{ Realística } & entende como um "fato da vida" & 3 & 01 \\
\hline & & destaca sua própria participação & 3 & 01 \\
\hline & & & Subtotal & 02 \\
\hline & & & Subtotal & 06 \\
\hline \multirow{8}{*}{ 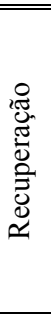 } & \multirow{4}{*}{ Realista } & sua própria vontade e atitudes & 3,8 & 02 \\
\hline & & apoio familiar & 3 & 01 \\
\hline & & sua própria crença na recuperação & 3 & 01 \\
\hline & & & Subtotal & 04 \\
\hline & \multirow{4}{*}{ Fatalista } & milagre & 9 & 01 \\
\hline & & vontade divina & 11 & 01 \\
\hline & & & Subtotal & 02 \\
\hline & & & Subtotal & 06 \\
\hline \multirow{6}{*}{ 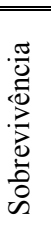 } & \multirow{3}{*}{ Fatalista } & vontade divina & 6,11 & 02 \\
\hline & & destino & 3 & 01 \\
\hline & & & Subtotal & 03 \\
\hline & \multirow{4}{*}{ Realística } & sua própria vontade de viver & 3 & 01 \\
\hline & & & Subtotal & 01 \\
\hline & & & Subtotal & 04 \\
\hline & & & Total & $\overline{16}$ \\
\hline
\end{tabular}

De acordo com a tabela 5, percebe-se maior predominância de justificativas fatalistas do que realísticas em relação ao fato de terem sobrevivido ao acidente, como, por exemplo, a vontade divina ou o destino, conforme relatado abaixo:

Pessoa 6: Eu caí e fui até Deus, fui lá no lado de Deus. Não mandei nenhum anjo meu, fui lá. Então não mandei anjo lá porque ia demorar, então eu fui falar com Deus. Eu falei: 
Deus eu quero viver. Deus teve piedade de mim. Eu senti ali que ele ia me dar essa chance. Onde hoje tô vivo, porque eu pedi pra Deus, me peguei com ele.

Em relação ao advento da lesão medular, pode-se destacar também, maior número de explicações fatalistas. Ela pode ser compreendida como relacionada ao destino (2 relatos), como um castigo (1 relato) ou reflexo da vontade divina (1 relato). Estas percepções encontram-se presentes nos seguintes depoimentos:

Pessoa 7: depois eu pensei assim, gente por mais que acontece as coisas, não tem culpa, porque o que é pra gente, é pra gente mesmo, não adianta

Pessoa 11: então eu não sei porque aconteceu isso na minha vida, mas se ele permitiu é porque deus sabe que eu tenho condições, não é porque eu quero não, mas é porque você tem que passar por isso

Com relação à recuperação que tiveram desde a época em que foram lesionados, os entrevistados consideraram a sua própria força e vontade de superar os obstáculos, bem como, a ajuda e apoio familiar recebidos. Basearam-se, principalmente, em explicações realísticas no que se refere às melhorias ocorridas após o advento da lesão. Isto pode ser exemplificado, no seguinte depoimento:

Pessoa 3: Mas enfim a minha recuperação foi muito rápida, graças a Deus a força de vontade foi muita, a fé, e meu pai e minha mãe sempre ali me ajudando, me dando força, porque o que mais ajuda uma pessoa numa situação assim é a família né? Porque se não é a família, a pessoa também não é nada.

Percebe-se que a recuperação depende da presença da família e de quão positivamente ela age em relação à pessoa com lesão medular. No entanto, nem sempre os conhecimentos acerca da lesão são esclarecidos suficientemente à família e à pessoa com lesão medular. $\mathrm{Na}$ tabela 6, são apresentados os conhecimentos que estas pessoas possuíam sobre a lesão antes de serem acometidos por esta deficiência. 
Tabela 6. Conhecimentos anteriores dos entrevistados sobre a lesão medular.

\begin{tabular}{ccc}
\hline CONHECIMENTO & P & F \\
\hline \hline não tinha alguma informação & $2,3,7,8,9,10,12$ & 07 \\
sabia apenas da imobilidade & $1,5,6$ & 03 \\
não sabia das causas & 12 & 01 \\
sabia apenas o que causava & 4 & 01 \\
\hline \hline
\end{tabular}

A falta de informação sobre todas as características desta deficiência no momento em que adquirem a lesão, é um fato citado com freqüência pelos entrevistados, como pode ser observado no seguinte relato:

Pessoa 1: Não conhecia nada. Eu tinha visto a pessoa na cadeira e só isto né? Eu sabia que atingia a coluna, a medula e acaba na cadeira e às vezes tinha a hérnia de disco e a gente via sempre uma pessoa ou outra, mas não sabia a fundo o que era né? Se alguém fosse me perguntar o que era, não tinha nem idéia.

A partir deste depoimento fica visível um conhecimento limitado sobre as conseqüências reais de uma patologia, como a lesão medular. Informações incompletas subsidiam uma compreensão incorreta sobre os efeitos da secção medular. Compreensão esta que se encontra caracterizada, principalmente, pela associação pura e simples entre lesão medular e imobilidade (cadeira de rodas). Os outros efeitos e implicações desta deficiência, como as várias funções fisiológicas e orgânicas comprometidas, ou mesmo as possibilidades existentes de tratamentos, assim como as dificuldades de recuperação, são informações que não faziam parte do conjunto de conhecimentos obtidos pela maioria desta população no momento em que adquiriram a lesão medular. Em menor número, encontra-se aquele que foi anteriormente informado somente sobre os riscos de se tornarem deficientes e aquele que não conhecia todas as causas possíveis (1 relato cada).

As declarações apontam para uma falta de conhecimento sobre a lesão medular, que está implícita em um contexto geral, já que a mesma é vista como uma incógnita para grande parte da população (SANTOS, L. 2000). A falta de conhecimentos ou as informações incorretas e obscuras sobre esta deficiência, além da crença fantasiosa de estarem imunes a 
uma situação como esta, aparecem como fatores desnorteadores para estas pessoas, como pode ser constatado em algumas de suas falas:

Pessoa 5: E também não sabia que não tinha cura, isso também não sabia. Fiquei sabendo depois que eu vim pra cadeira de rodas porque eu achava que o cara que vinha na cadeira de rodas é porque já nasceu com aquele problema. Só que não é bem assim né, todos nós estamos sujeitos a ir pra uma cadeira de rodas e até ficar na cama devido a um acidente, alguma coisa assim...

Pessoa 9: A gente é muito desinformado e a gente também é assim: quando você não tem o problema, nem tem na família, você nem se interessa né... Tipo a AIDS aí... tá tão banal você escutar aquilo na televisão, que nem choca mais. Mas quando você tem um caso perto, aquilo já te choca né... Porque você escuta mas você se acha assim inatingível. Eu nunca parei pra pensar que um dia eu fosse tá numa cadeira. Ninguém nunca para pra pensar! Ninguém nunca para pra pensar que um dia possa ser um portador da AIDS, ninguém tá imune. Ninguém pensa na morte, que um dia vai morrer. Só pensa na morte quando você tá com uma doença bem grave né? Não, eu nunca... Até tinha pessoas que iam no banco, que estavam na cadeira, mas eu nunca me interessei pra conversar, de perguntar, de curiosidade pra isso.

Pessoa 6: Bombeiro né? Já e tinha aquele pensamento: Ah, comigo não acontece. E trabalhava lá no lado. A cada minuto lá...eu trabalhava do lado do HC. No pronto socorro do HC de São Paulo. Lá você teme até pelo filho que você ainda não teve. É horrível! No corredor você só vê gente arrebentada. Nossa aqui não é nada. Eu levava as pessoas e tal, eu pegava a maca, colocava na viatura.

As Pessoas 6 e 9 comentam o fato de nunca terem pensado na hipótese de adquirir uma lesão medular, embora se deparassem com vários tipos de patologias crônicas, de forma corriqueira em seu ambiente de trabalho ou nas suas vivências diárias. Ao se encontrarem nesta situação eles percebem que a ocorrência de uma lesão medular é um evento bastante 
comum e que ninguém está imune a uma situação como esta, já que ela atinge pessoas de todas as raças, lugares, idades, ocupações, educações e renda (CORBET, 1985).

Observa-se que, embora a lesão medular se constitua como algo próximo à vida de qualquer pessoa, ela é muitas vezes negada como possibilidade e como realidade de muitos. Esta negação acontece, em diversos casos, na forma de indiferença, como algo que não pode ser visto, embora esteja presente nas ruas, no trabalho, na escola, enfim, em todos os ambientes onde as pessoas estão inseridas. Goffman (1988), relata o afastamento em relação à pessoa acometida por uma deficiência, como um comportamento social muito comum, já que a deficiência impõe a atenção sobre a pessoa e seus atributos. Desta forma, a presença de uma aparência marcada pela diferença (que foge do padrão de normalidade ou de beleza estipulado socialmente), pode causar um certo desconforto, que torna-se justificado quando se atribui a esta pessoa a condição de inadequada para o contato social (OMOTE, 2003). Para o referido autor a visibilidade da deficiência exerce uma influência significativa na percepção que se tem da mesma. Segundo suas pesquisas, quando o comprometimento não é de alta visibilidade, a alta atratividade simplesmente pode levar as pessoas a não perceberem a criança [pessoa] como sendo deficiente (p. 58). No caso da lesão medular, esta visibilidade encontra-se evidenciada, no entanto ela pode variar no que se refere ao nível e grau de comprometimento e adequação aos padrões de beleza e de um corpo perfeito, determinando a maneira em que serão percebidos e abordados. Estas diferenciações podem ser contempladas no seguinte relato:

Pessoa 2: Porque às vezes as pessoas me vêem na cadeira e não ta na cara que é uma lesão medular porque eu não mostro no meu rosto, não tem uma perna torta, ou não tem um braço né? Então eu tenho um corpo que ta normal, então as pessoas têm interesse de saber: porque você ta tão saudável e ta numa cadeira?

Pessoa 3: Agora o deficiente físico, já um tetra ou uma pessoa que sofreu um acidente e perdeu um membro, uma coisa ou outra, eu acho que estes sim se sentem um pouco denegridos. Porque eu acho que eles se sentem, vamos dizer assim, um pouco feios perante a sociedade. O formato do corpo... 
Nesta perspectiva, suas vivências anteriores, valores, identidade construída, assim como seus conhecimentos sobre esta deficiência assumem um papel bastante significativo no que se refere à forma como esta ou aquela pessoa irá se deparar com um acontecimento considerado extremamente traumático, já que pode representar uma ruptura em todos os aspectos de sua vida. As primeiras reações dos entrevistados, ao se perceberem como lesados medulares, encontram-se explícitas na tabela 7.

Tabela 7. Primeiras reações à lesão medular.

\begin{tabular}{|c|c|c|c|}
\hline & REAÇÃO & $\mathbf{P}$ & $\mathbf{F}$ \\
\hline & tristeza & $2,4,7,9$ & 04 \\
\hline & revolta & $2,7,8,10$ & 04 \\
\hline & impotência & 2,5 & 02 \\
\hline है & frustração & 2,4 & 02 \\
\hline 苛 & $\begin{array}{l}\text { não demonstrou } \\
\text { sentimentos }\end{array}$ & 9 & 01 \\
\hline & desânimo & 10 & 01 \\
\hline & preocupação & 12 & 01 \\
\hline & & Subtotal & 15 \\
\hline & $\begin{array}{c}\text { rença em uma recuperação } \\
\text { imediata }\end{array}$ & $2,3,5,7,11$ & 05 \\
\hline & & Subtotal & 05 \\
\hline & negação & $5,9,10$ & 03 \\
\hline & & Subtotal & 03 \\
\hline & choque & 1,9 & 02 \\
\hline & & Subtotal & 02 \\
\hline & descrença & 3,8 & 02 \\
\hline & & Subtotal & 02 \\
\hline & lesestruturação emocional & 11 & 01 \\
\hline & & Subtotal & 01 \\
\hline & essidade de reconhecimento & 3 & 01 \\
\hline & & Subtotal & 01 \\
\hline & desorientação & 3 & 01 \\
\hline & & Subtotal & 01 \\
\hline & questionamento & 12 & 01 \\
\hline & & Subtotal & 01 \\
\hline & & Total & 31 \\
\hline
\end{tabular}

A tabela 7 mostra que os entrevistados, ao entrarem em contato com sua deficiência, se depararam, principalmente, com sentimentos que variavam de tristeza à preocupação. Os 
sentimentos de tristeza e revolta apareceram representando os sentimentos mais comuns nesta população, em específico, e encontram-se presentes nos seguintes relatos:

Pessoa 2: Eu me senti triste, porque eu não imaginava que a minha vida ia parar. Eu tinha muitos sonhos, de ser a bailarina né, e a partir do momento que eu me vi numa cadeira de rodas eu pensei: O que eu vou fazer agora? Eu fiquei triste porque eu era uma criança, uma criança que gostava de fazer bagunça, de brincar de boneca, de andar de bicicleta, pular corda, amarelinha... e eu não podia mais.

Pessoa 10: Fiquei revoltado né, não tinha como... nossa você ter uma vida normal, tranqüilo, sem depender de ninguém pra fazer nada e depois voltar dependente, foi muito dificil!

Dewis (1989) relata o significado de ruptura trazido por uma patologia como a lesão medular, já que mudanças drásticas ocorrem inusitadamente em suas vidas, passando muitas vezes, de uma condição de independência e auto-suficiência para uma vida onde é necessário se adaptar a vários artifícios mecânicos de locomoção e de treinamentos médicos, além da vivência de inúmeras complicações orgânicas e extensas hospitalizações. Fonseca (1995), ressalta que a presença de uma deficiência por si só, torna-se um fator desestruturador, já que a mesma representa uma ameaça a "ordem" estabelecida socialmente. Muitos autores relatam, como conseqüências de uma doença crônica como a lesão medular, os distúrbios emocionais, depressão e até tentativas de suicídio (BRYAN e HERJANIC, 1980; KHAN, HERNDON e AHMADIAN, 1971).

Entretanto, o comportamento marcado pela crença em uma recuperação imediata, também é muito comum em seus depoimentos, e claramente perceptível no seguinte relato:

Pessoa 2: Antes, quando eu sofri o acidente, eu não sabia, eu sempre pensava, ah, eu vou voltar a andar, eu vou voltar a andar. E não chegava nunca o dia, então eu não ligava tanto pra minha cadeira. 
Reações como desestruturação emocional, desorientação, necessidade de reconhecimento corporal e questionamento, foram citadas apenas com uma resposta cada uma. Percebe-se entretanto, que cada participante esboça o seu mecanismo de reação e enfrentamento. As formas de enfrentamento utilizadas por estas pessoas ao se depararem com a deficiência física estão ilustradas na tabela 8.

Tabela 8. Formas de enfrentamento.

\begin{tabular}{c|ccc}
\hline \multicolumn{1}{c}{ FORMA DE ENFRENTAMENTO } & P & F \\
\hline \hline \multirow{4}{*}{ Suportes } & profissional & $1,2,4,6,7,8,11$ & 07 \\
& espiritual & $2,6,8,11$ & 04 \\
& social & $2,8,11$ & 03 \\
& familiar & $2,8,11$ & 03 \\
& & Subtotal & 17 \\
\hline \hline \multirow{2}{*}{ Investimentos } & vida pessoal & 2,5 & 02 \\
em si mesmos & vida profissional & 2 & 01 \\
& & Subtotal & 03 \\
\hline \hline apoio no exemplo de outros & $2,5,6$ & 03 \\
& & Subtotal & 03 \\
\hline \hline \multicolumn{2}{c}{ busca de informações } & $3,7,11$ & 03 \\
& & Subtotal & 03 \\
\hline \hline avaliação de suas possibilidades & 2,6 & 02 \\
& Subtotal & 02 \\
\hline \hline reconhecimento de ganhos com a lesão & 2 & 01 \\
(reformulação) & Subtotal & 01 \\
\hline \hline & avaliação passiva & Subtotal & 01 \\
\hline \hline
\end{tabular}

De acordo com a tabela 8, pode-se inferir que, apesar de todas as perdas advindas de uma deficiência como esta e de todos os sentimentos desnorteadores, parece haver uma tendência a buscar caminhos, variados, para superar, ou aprender a viver com aquela deficiência. Eles se sentem, neste momento, em condições de continuar sua vida pósdeficiência e as atividades exercidas, a partir daí, estarão em grande parte relacionadas com um investimento reabilitacional, assumindo-se, portanto, uma forma de enfrentamento marcada, principalmente, pelo suporte profissional. Este fenômeno pode ser exemplificado nos relatos seguintes: 
Pessoa 2: Então você tem que ir tentando seguir a sua vida, tentando ver o que tem de oportunidade pra você, fazer tratamento com o Dr. Cliquet, ir fazer fisioterapia, ir em busca de novas alternativas pra sua vida. Não se vê limitada.

Pessoa 4: Então, eu tô fazendo fisioterapia, eu tô fazendo esses tratamentos aqui e torcendo pra que eu volte a andar né?

Estes depoimentos revelam, ainda, investimentos em si mesmos, apoio no exemplo de outros, busca de informações tanto técnicas como as relativas às trocas de experiências com pessoas que possuem a mesma deficiência e a avaliação de suas possibilidades. $\mathrm{O}$ reconhecimento de ganhos com a lesão ou reformulação, assim como a avaliação passiva ou conformismo, aparecem com apenas uma resposta cada um. Uma avaliação positiva de sua vida é enfocada por um dos entrevistados e explicitada em seu depoimento:

Pessoa 11: mas isso eu coloco pra mim que é as coisas mínimas, porque as coisas grandes... eu tenho apoio sabe?

Como constatado a partir destes relatos, a percepção de mudanças advindas de uma lesão medular pode assumir significados diferentes para cada pessoa, de acordo com suas crenças, valores e experiências de vida. Na tabela 9, estas pessoas se referem a algumas mudanças consideradas por elas importantes, bem como, seus respectivos significados. 
Tabela 9: Significado de mudanças ocorridas a partir da lesão.

\begin{tabular}{|c|c|c|c|c|}
\hline MUDANÇA & & $\begin{array}{c}\text { SIGNIFICADO } \\
\end{array}$ & $\mathbf{P}$ & $\mathbf{F}$ \\
\hline \multirow{7}{*}{ Pessoal } & \multirow{7}{*}{\multicolumn{2}{|c|}{$\begin{array}{c}\text { possibilidade da construção de uma nova vida } \\
\text { (buscando alternativas e lutando pela superação) } \\
\text { inutilidade, impotência, dependência } \\
\text { interrupção de planos / objetivos de vida (perda de oportunidade } \\
\text { de estudo e profissional) } \\
\text { redimensionamento de valores } \\
\text { maiores conhecimentos } \\
\text { perda de conforto material }\end{array}$}} & $2,4,5,6,8,11$ & 06 \\
\hline & & & $3,8,10,12$ & 04 \\
\hline & & & $1,2,4,7$ & 04 \\
\hline & & & 7,11 & 02 \\
\hline & & & 5 & 01 \\
\hline & & & 7 & 01 \\
\hline & & & Subtotal & 18 \\
\hline \multirow{6}{*}{ Funcional } & \multirow{2}{*}{\multicolumn{2}{|c|}{ " dificuldades nas atividades diárias (reaprendizado) }} & "4,7,10,11 & 04 \\
\hline & & & Subtotal & 04 \\
\hline & \multirow{3}{*}{$\begin{array}{c}\text { Utilização } \\
\text { da cadeira } \\
\text { de rodas }\end{array}$} & $\begin{array}{c}\text { uma parte de seu corpo } \\
\text { (reestruturação da imagem corporal) } \\
\end{array}$ & 1,2 & 02 \\
\hline & & uma necessidade & 2 & 01 \\
\hline & & & Subtotal & 03 \\
\hline & & & Subtotal & 07 \\
\hline \multirow{2}{*}{ Social } & \multirow{2}{*}{\multicolumn{2}{|c|}{ reestruturação }} & 9 & 01 \\
\hline & & & Subtotal & 01 \\
\hline \multirow{5}{*}{ Física } & \multirow{2}{*}{\multicolumn{2}{|c|}{ "reestruturação da imagem corporal }} & 9 & 01 \\
\hline & & & Subtotal & 01 \\
\hline & \multirow{3}{*}{\multicolumn{2}{|c|}{ " não percebe mudanças }} & 3 & 01 \\
\hline & & & Subtotal & 01 \\
\hline & & & Total & 28 \\
\hline
\end{tabular}

Observam-se, mudanças pessoais ( 8 relatos), funcionais (7 relatos), sociais (1 relato) e físicas (1 relato), desencadeadas pelo advento da lesão medular, além de um relato evidenciando a inexistência de ocorrência de mudanças. Eles entendem que as mudanças ocorridas com o estabelecimento da lesão medular os colocam exatamente no lugar da construção de uma nova vida, embora com algumas limitações. Com o advento da deficiência, a vida pode adquirir um novo significado para estas pessoas.

É muito importante perceber a representação da vivência de uma situação traumática para este sujeito. A partir do advento da lesão, sua vida pode tomar uma nova dimensão, como é mostrado nos discursos que se seguem:

Pessoa 2: De repente eu estaria nas drogas, de repente eu já fosse mãe, mas isso não me impede de na cadeira ser, não me impede de usar drogas, mas eu não penso nisso, eu vejo a minha vida como um milagre. Se eu não morri naquele acidente é porque alguma coisa de importante, de especial Deus preparou pra mim. 
Pessoa 5: Eu encarei como um desafio, como eu encaro até hoje, como um desafio, como uma luta, minha vida sempre foi uma luta, e eu encaro assim. Encarei e encaro assim até hoje. Como um desafio e sempre esperançoso de que um dia a vitória virá... em nome de Jesus.

De acordo com os relatos dos entrevistados, o fato de se estar vivo e de poder lutar pela sua recuperação passam a ser considerados como um "trunfo", ocupando, portanto, um lugar especial e muito valorizado na vida destas pessoas.

Outros relatos também significativos, notificam as dificuldades diárias, o sentimento de inutilidade, impotência ou dependência, e até mesmo interrupção de planos e objetivos de vida. Também a imagem corporal precisa ser reestruturada, devido a todas as mudanças físicas trazidas pela lesão e pela inclusão dos utensílios de apoio em seu dia-dia, como por exemplo, a cadeira de rodas. Este instrumento passa a ter um novo significado para eles, tornando-se, de alguma forma, uma parte de seu corpo. As características desta sua nova vida são explicitadas no seguinte relato:

Pessoa 2: Isto aqui é... é falta de informação de uma pessoa que andava. É de você não aceitar essa cadeira como pernas e sim como um instrumento de ai... é necessidade né? Eu só via como necessidade. Quando eu vi que eram pernas então eu pensei: perai é uma necessidade, mas são pernas também.

Pode-se constatar, a partir destes resultados, uma necessidade de reconstrução e reelaboração de objetivos de vida, da sua imagem corporal e da percepção que possuem sobre si mesmos. Tais informações encontram-se resumidas na tabela 10 (respostas referentes aos efeitos positivos e negativos advindos da lesão medular). Os aspectos positivos e negativos de uma lesão medular podem ser caracterizados em falas dos entrevistados, a partir das mudanças que se encontram relacionadas com o advento da lesão. Pode-se dizer que grande parte destas mudanças é considerada positiva e se concentra, principalmente, no que tange a maior percepção que estas pessoas começam a ter, com maior valorização de si mesmos, da vida familiar, das pessoas, de todos os 
acontecimentos ocorridos em suas vidas, da vida como um todo, das vivências relacionadas ao seu dia-dia, do seu comportamento, da sua capacidade de superação e até mesmo do deficiente de uma forma geral. Compreende-se, portanto, que os principais efeitos advindos da lesão medular se referem a uma mudança de posicionamento perante às situações vivenciadas por estas pessoas. Com tudo isto, começa a haver um redimensionamento de valores, como pode ser apreendido em uma das falas, a saber:

Pessoa 6: Saber conversar, saber se comunicar... tudo, em geral, em tudo... a minha lesão fez isso. Eu era muito eu. Eu posso, eu falo, eu mando, eu faço, eu aconteço, eu... tudo eu. Hoje não existe eu, existe nós. Dá pra você fazer? Você pode fazer? Será que você pode fazer isso pra mim? Hoje é nós, não eu, porque se sou eu hoje, eu falo: Você pode fazer aquilo e numa estupidez você fala eu não vou. Se eu falar: Pega isso aqui pra mim, pega lá, e você diz: Não vou pegar. E aí, o que que eu faço? Vai ficar lá. Agora se eu falar: você pode fazer o favor de pegar isso pra mim? Sente a mudança? Do pega lá, tô mandando e do Você pode pegar fazendo o favor? Não há diferença? Essa é a diferença que houve na minha vida. Eu não pedia, eu mandava. Hoje eu peço. Porque se eu mandar hoje, você não vai fazer e eu fico sem. Então na minha situação, a minha lesão me trouxe assim... mudou tudo na minha vida. 
Tabela 10. Efeitos provenientes da lesão medular.

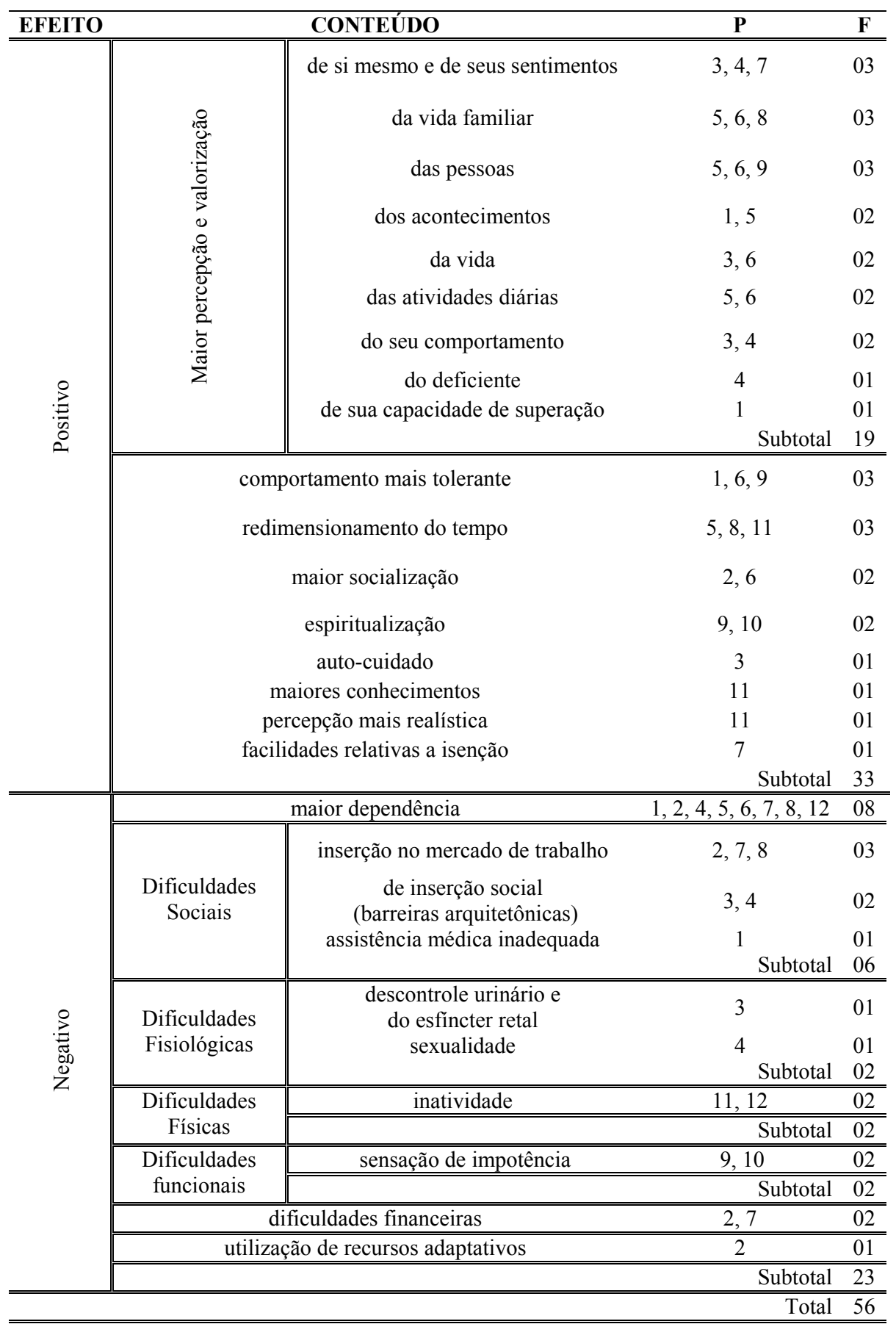

Observa-se que as mudanças de atitudes perante a vida e às pessoas, advinda deste redimensionamento de valores, também citado na tabela 9, são ressaltadas como um dos pontos positivos trazidos por uma lesão medular, além da crença de que a mesma possibilitou um novo olhar sobre a vida. A necessidade de estabelecer vínculos de ajuda 
acaba trazendo a estas pessoas uma capacidade maior de se relacionarem socialmente e, também, de procurarem serem mais atenciosos, compreensivos, amáveis e flexíveis com aqueles que estão a sua volta, já que, devido às características de sua lesão, estas pessoas passam a depender dos chamados cuidadores. O cuidar para eles assume, porém, uma nova dimensão, de forma que eles passam a dar mais importância a este aspecto do relacionamento humano, que é cuidar e ser cuidado. No entanto, o auto-cuidado é um efeito citado em apenas um dos relatos. O redimensionamento do seu tempo é também percebido como um efeito proeminente da lesão medular. Com o advento da lesão, a vida diária destas pessoas é radicalmente modificada, de maneira que, o tempo assume uma nova dimensão. Este fato, já constatado em estudos realizados por Santos, L. (2000), afirma-se na explicação de que a lesão medular possibilitou a existência de mais tempo para cuidarem de si e de suas famílias, como é observado no relato abaixo:

Pessoa 5: Antes eu não tinha tempo para poder enxergar isso, porque a minha vida era intensa no quartel, como eu falei, então eu não tinha esse tempo para a minha família. $O$ tempo que eu tinha era o fim de semana e no fim de semana você faz o que? É lazer, você quer levar sua família no parque, você quer ir na praia, você quer ir numa churrascaria, numa pizzaria, você quer passear com a sua família, que às vezes o problema em si, que as vezes tá dentro da sua casa, você não percebe, problema psicológico que existia dentro de casa, alguma coisa que acontecia, na escola, ou algum problema que a ...[esposa] pudesse resolver né, eu não tava sabendo. E agora não, com essa lesão, depois que eu fui pra cadeira de rodas eu pude participar mais, nesse aspecto, né? O ponto positivo é esse, pelo fato de eu ter mais tempo pra minha família, embora não ativamente como eu era antes, mas assim, de uma forma presente foi bom.

Com relação aos efeitos negativos provenientes da lesão medular, consideram uma maior dependência de outras pessoas (já citada na tabela 9). Tal condição é considerada difícil para esta população. É ressaltada, em suas falas, a necessidade de uma maior adaptação da sociedade para incluir o deficiente físico, tanto nos aspectos estruturais, como em transportes mais adequados, rampas que facilitem a sua locomoção, facilitação financeira para aquisição de carros adaptados, cadeiras e equipamentos imprescindíveis para o 
deficiente, assim como ambientes mais adequados para que o mesmo possa exercer uma vida social considerada normal. Isto mostra o despreparo da sociedade no sentido de exercer as políticas de apoio e de inclusão social do deficiente. Suas considerações sobre este fato, podem ser percebidas no seguinte depoimento:

Pessoa 4: No meu caso, eu, graças a Deus, eu tive condição de comprar um carro pra me locomover que a minha esposa dirige e que eu possa dirigir. Mas de repente, se eu não tivesse condição de comprar um carro, pra eu ir pra algum lugar eu não teria condição, porque os transportes estão super precários. Então tudo isso daí influencia bastante. Porque você de pé, você pode ir pra qualquer lugar, você pode fazer quase qualquer coisa. Na cadeira de roda não, você fica preso, muito preso. Pelas próprias condições né? Que a gente tem.

Conclui-se, a partir dos resultados apresentados nas tabelas 9 e 10, que a lesão medular não se tornou para estas pessoas algo essencialmente negativo. Tal constatação também pode ser observada a partir de alguns dos seus relatos:

Pessoa 3: no meu ver não existe negativismo. Só positivo.

Pessoa 6: No meu caso foi muito positivo.

A tabela 11 informa as dificuldades enfrentadas tanto pelos entrevistados, quanto pelas pessoas que se encontram na condição de lesados medulares de uma forma geral, no momento em que os mesmos se remetem à categoria ou à população acometida por uma lesão medular, conforme foram interrogados na questão que se refere às dificuldades enfrentadas pela pessoa com lesão medular, de uma forma geral. 
Tabela 11. Principais dificuldades enfrentadas pelos entrevistados e pelas pessoas com lesão medular de uma forma geral, de acordo com o depoimento dos entrevistados.

\begin{tabular}{|c|c|c|c|c|}
\hline REFERÊNCIA & \multicolumn{2}{|c|}{ DIFICULDADE } & $\mathbf{P}$ & $\mathbf{F}$ \\
\hline \multirow{15}{*}{ 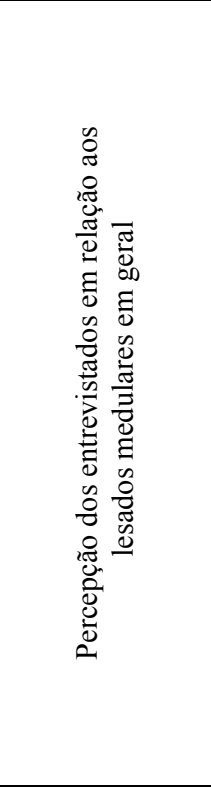 } & \multirow{3}{*}{ Social } & \multirow{3}{*}{\begin{tabular}{|c|} 
na interação social \\
preconceitos \\
inserção social (barreiras \\
arquitetônicas e transporte)
\end{tabular}} & $\begin{array}{l}4,5,9 \\
2,5,9\end{array}$ & $\begin{array}{l}03 \\
03\end{array}$ \\
\hline & & & 8,10 & 02 \\
\hline & & & Subtotal & 08 \\
\hline & \multirow{3}{*}{ Acessibilidade } & $\begin{array}{c}\text { as informações sobre a } \\
\text { lesão }\end{array}$ & $1,2,7$ & 03 \\
\hline & & $\begin{array}{l}\text { aos tratamentos } \\
\text { reabilitacionais }\end{array}$ & 1,7 & 02 \\
\hline & & & Subtotal & 05 \\
\hline & \multirow{3}{*}{ Familiar } & reações inadequadas & 4,6 & 02 \\
\hline & & ausência de apoio & 2 & 01 \\
\hline & & & Subtotal & 03 \\
\hline & Pessoal & aceitação & $\begin{array}{l}2,3,9 \\
\text { Subtotal }\end{array}$ & $\begin{array}{l}03 \\
03\end{array}$ \\
\hline & Financeira & "financeira & $\begin{array}{c}1,6 \\
\text { Subtotal }\end{array}$ & $\begin{array}{l}02 \\
02\end{array}$ \\
\hline & \multirow{3}{*}{ Física } & sexual & 11 & 01 \\
\hline & & fisiológica & 12 & 01 \\
\hline & & & Subtotal & 02 \\
\hline & & & Subtotal & 23 \\
\hline \multirow{15}{*}{ 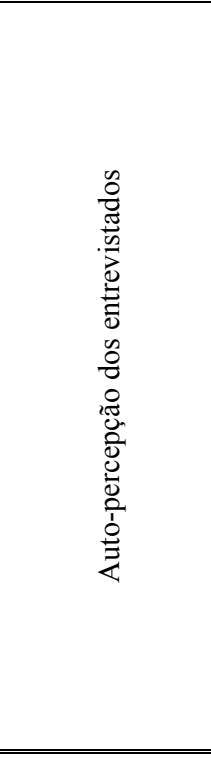 } & & $\begin{array}{l}\text { condicionamento e } \\
\text { estrutura corporal }\end{array}$ & $1,3,8$ & 03 \\
\hline & Física & de locomoção & $5,9,12$ & 03 \\
\hline & & sexual & & 01 \\
\hline & & & Subtotal & 07 \\
\hline & \multirow{2}{*}{ Social } & $\begin{array}{c}\text { inserção social } \\
\text { (barreiras arquitetônicas) }\end{array}$ & $5,4,9$ & 03 \\
\hline & & de relacionamento social & $\begin{array}{c}5 \\
\text { Subtotal } \\
\end{array}$ & $\begin{array}{l}01 \\
04\end{array}$ \\
\hline & Funcional & $\begin{array}{l}\text { atividades de vida diária } \\
\text { transferência }\end{array}$ & $\begin{array}{c}7,10 \\
8 \\
\text { Subtotal }\end{array}$ & $\begin{array}{l}02 \\
01 \\
03\end{array}$ \\
\hline & \multirow{3}{*}{ Pessoal } & emocionais & 5 & 01 \\
\hline & & conjugais & 5 & 01 \\
\hline & & & Subtotal & 02 \\
\hline & & ao mercado de trabalho & 2 & 01 \\
\hline & \multicolumn{2}{|c|}{ Acessibilidade } & Subtotal & 01 \\
\hline & \multirow{2}{*}{\multicolumn{2}{|c|}{ indica ausência de dificuldades }} & 6 & 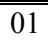 \\
\hline & & & Subtotal & 01 \\
\hline & & & Subtotal & 18 \\
\hline & & & Total & \\
\hline
\end{tabular}

Conforme ilustra a tabela 11 , os entrevistados identificaram maior número de dificuldades relativas às pessoas com lesão medular de uma forma geral, do que em relação a sua própria condição. Do ponto de vista da percepção dos entrevistados sobre os lesados medulares, em geral, identificaram-se um maior número de dificuldades relacionadas aos aspectos sociais, de acessibilidade, familiares, pessoais, financeiras e físicas. Os entrevistados enfatizaram as dificuldades enfrentadas pela pessoa com lesão medular, tais 
como, falta de acesso às informações e aos tratamentos existentes que se direcionam a esta patologia; dificuldades na aceitação da lesão medular e de suas conseqüências; ausência de apoio familiar ou assistência familiar inadequada; de interação e inserção social; o enfrentamento de preconceitos e as dificuldades financeiras comuns às pessoas que apresentam este quadro, além dos problemas físicos relacionados à sexualidade e reações fisiológicas. De acordo com eles, as maiores dificuldades da pessoa com lesão medular são de caráter social, já que, na maior parte de seus relatos, eles focalizaram as dificuldades destas pessoas no que se refere à sua interação social. A interação com o mundo e com as pessoas de uma forma geral foi considerada por eles, como algo imprescindível em suas vidas e na vida da pessoa com lesão medular como um todo. Esta percepção permitiu que eles entendessem o isolamento do deficiente e a exclusão social, como problemas que devem ser superados. Estas questões encontram-se explícitas nas seguintes falas:

Pessoa 4: Acho que a falta dele se expor. Tipo assim dá a cara pra bater: Olha, sou deficiente fisico, tenho esse problema...

Pessoa 5: Eu acho que é a convivência social. Eu não tô falando de mim, eu tô falando de uma forma geral.

A existência de preconceito é enfatizada como um fator dificultador nas relações estabelecidas pela pessoa com lesão medular. Este aspecto é identificado no relato que se segue:

Pessoa 9: Porque quando você passa por uma situação dessa as pessoas parecem que te vêem diferente. Te vêem como criança, como um débil mental, que não pode responder por si próprio, não pode fazer as coisas por si só... aí isso aí você vai ter que reconquistar o seu espaço entendeu?

Um enfrentamento deste quadro que lhe permita continuar vivendo e se realizando nos seus papéis sociais, familiares, profissionais e etc, é visto como algo muito difícil e doloroso. 
Este fato é reconhecido em suas falas como uma dificuldade comum a muitos portadores de lesão medular. Pode-se constatar esta afirmação no depoimento, a seguir:

Pessoa 2: só que tem aqueles que conseguiram e tem aqueles que desistiram e se revoltaram, ficaram tristes.

Quanto as suas próprias dificuldades, eles apontaram, principalmente, para algumas preocupações com o seu corpo ou de locomoção, outras relacionadas com as inúmeras limitações que o meio social impõe aos deficientes físicos e, também, àquelas referentes ao exercício das atividades de vida diária. Dificuldades estas, intimamente relacionadas com a sensação de dependência, citada na tabela 10, como o principal efeito negativo advindo de uma lesão medular. As que dizem respeito à sua estrutura física são dificuldades que podem prejudicá-los em seu processo reabilitacional, como por exemplo, o condicionamento físico e o peso excessivo. Elas podem ser vislumbradas nos relatos abaixo:

Pessoa 1: Hoje a minha maior dificuldade é o condicionamento físico. Eu preciso ta fazendo uma musculação na minha casa, alguma coisa pra eu ta me condicionando mais porque eu canso muito rápido. Tanto aqui, quanto lá e se trabalha muito nisso eu faço hidro, o meu condicionamento ta melhor, ta melhorando, mas ainda ta meio baixo. Eu não sei se é porque eu engordei um pouco e isso ajuda bastante, mas o meu condicionamento ainda é minha maior dificuldade.

Pessoa 3: Emagrecer. Minha maior dificuldade é essa.

As dificuldades de locomoção e as barreiras arquitetônicas também apareceram em alguns de seus discursos, como alguns dos seus maiores obstáculos:

Pessoa 5: A minha maior dificuldade é andar, poder ir aonde você quer ir sem empecilho nenhum. Que na realidade hoje não é, se você vai pra algum lugar você tem mais dificuldade que qualquer um, porque a estrutura hoje do comércio, do povo em si, não está preparada para o deficiente. Tá melhorando, mas não está preparado. Você anda pela 
cidade... não tem rampa, você vê numa repartição pública não tem rampa, você vai num restaurante não tem rampa... então tudo isso são as dificuldades. E a maior justamente é essa, de você não poder ter acesso a tudo. Porque o acesso é limitado. Hoje tá tudo limitado!

Somente P6, afirmou não possuir alguma dificuldade, como pode ser evidenciado no conteúdo do seu depoimento:

Pessoa 6: Eu não tenho [dificuldades]. Sinceramente.

Na tabela 12, encontram-se contempladas as principais necessidades da pessoa com lesão medular, de acordo com os entrevistados.

A partir das dificuldades da pessoa com lesão medular, pode-se inferir quais as suas necessidades. No entanto, analisando as falas dos entrevistados sobre as principais necessidades referentes à pessoa com lesão medular, foi constatado que as mais prementes são àquelas que se restringem ao âmbito governamental. Seriam elas: o maior acesso do deficiente ao mercado de trabalho, como também o acesso aos ambientes sociais e de trabalho (citadas como uma de suas principais dificuldades na tabela 11). Eles acreditam, ainda, que é necessária a implantação de políticas que possam proporcionar ao deficiente uma melhor qualidade de vida. Os depoimentos que se seguem ilustram algumas destas necessidades:

Pessoa 6: Por exemplo, inventaram esse negócio de isenção de carro, mas ninguém tem condição de comprar. Podia facilitar assim, da pessoa poder ter uma casa de apoio pra ela. Ter condição de ter. Vantagem né, alguma coisa assim, alguém pra cuidar dos que são sozinhos, até se acostumar, emprego...

Pessoa 12: Eu não vejo assim, por parte do sistema, nenhum tipo de ajuda mais abrangente para o deficiente. Eles não facilitam nada. 
Tabela 12. Principais necessidades da pessoa com lesão medular.

\begin{tabular}{c||ccc}
\hline \multicolumn{1}{l|}{ NECESSIDADE } & CONTEÚDO & P & F \\
\hline \multirow{4}{*}{ Apoio } & oferecer maior acesso ao mercado de trabalho & $1,4,7,12$ & 04 \\
& implantação de políticas de apoio ao deficiente & $1,7,8,12$ & 04 \\
governamental & oferecer acesso aos ambientes sociais e de trabalho & $1,3,9,10$ & 04 \\
& (adaptação arquitetônica e transporte adaptado) & $3,4,12$ & 03 \\
& oferecer maior acesso aos serviços de saúde & 4,6 & 02 \\
& oferecer maior acesso às informações científicas & 2 & 01 \\
& oferecer mais oportunidades de uma forma geral & 4 & 01 \\
& oferecer acesso à formação escolar & 3 & 01 \\
& maior apoio às pesquisas & Subtotal & 20 \\
\hline \hline \multirow{3}{*}{ Social } & & $5,8,11$ & 03 \\
& & 2,5 & 02 \\
Educacional e & oferecer apoio ao deficiente & Subtotal & 05 \\
\hline \hline \multirow{2}{*}{ Profissional } & visão mais realística da deficiência & 1,12 & 02 \\
& & 4 & 01 \\
Familiar & exercício de atividades profissionais & Subtotal & 03 \\
\hline \hline & uma melhor formação escolar & 9 & 01 \\
Pessoal & & Subtotal & 01 \\
\hline \hline
\end{tabular}

Observa-se que as necessidades não se restringem àquelas que devem ser direcionadas diretamente ao deficiente, mas também as relativas a todos os trabalhos que contemplem o deficiente e suas dificuldades.

As necessidades diretamente relacionadas com o deficiente, associadas à remuneração, sua percepção e comportamento perante a sua lesão, apoio familiar, tratamentos mais adequados, aparecem com menor freqüência, assim como as relativas a sua formação escolar. Este conjunto de informações remete à caracterização da situação atual em que se encontram os entrevistados, como mostra a tabela 13. 
Tabela 13. Situação de vida atual dos entrevistados.

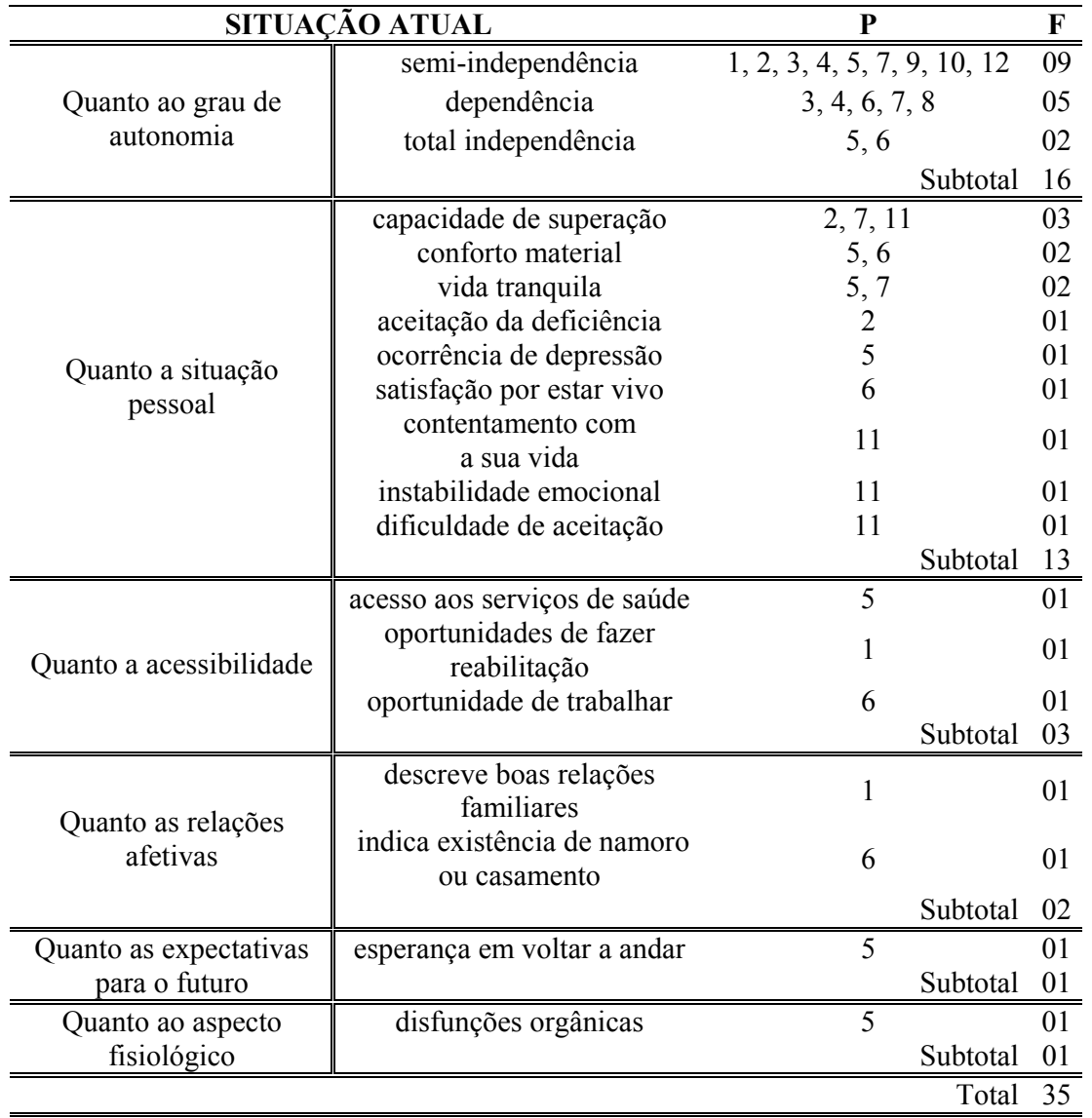

A compreensão de como os entrevistados percebem a sua vida hoje é um aspecto que deve ser analisado, com o objetivo de se obter um maior entendimento de como estas pessoas se sentem na situação de deficientes físicos e lesados medulares, com todas as especificidades desta patologia. Observa-se na tabela 13, que estas percepções oscilam, podendo se referir, em alguns momentos, a uma vida caracterizada por dificuldades e sintomas patológicos, como é depreendido de algumas de suas falas. Estas indicam a predominância de dependência (5 relatos), depressão (1 relato), disfunções orgânicas (1 relato), instabilidade emocional (1 relato), dificuldade de aceitação (1 relato), totalizando oito respostas. Entretanto, na sua maior parte, observa-se uma vida considerada estável, baseada no seu poder de superação (3 relatos), em um conforto material (2 relatos), na tranquilidade alcançada (2 relatos), nas oportunidades reabilitacionais e de trabalho (2 relatos), nas conquistas afetivas (namoro e casamentos) e boas relações familiares (2 relatos), na 
satisfação por estar vivo (1 relato), na confiança em alcançar a recuperação da locomoção (1 relato), na aceitação da deficiência (1 relato), no acesso aos serviços de saúde (1 relato) e no contentamento com a sua vida de uma forma geral (1 relato), totalizando 16 relatos.

Segundo Greve et. al (2001), somente através de uma reflexão profunda sobre as conseqüências desta patologia em sua vida e sobre o que ainda possui de possibilidades, a pessoa com lesão medular se sentirá em condições de alcançar um melhor ajustamento a sua deficiência, de maneira a se restabelecer em todas as suas atividades normais. Ela indica a ocorrência de mudanças drásticas e, muitas vezes, até irreversíveis em suas vidas, mas possíveis de serem enfrentadas, como é exemplificado no seguinte depoimento:

Pessoa 2: Eu procuro olhar e aceitar do jeito que ta, eu acho que pra qualquer pessoa você tem que aceitar a sua condição. Andando ou não, escutando ou não, é o que você é. Se isso ta na sua vida é porque você tem capacidade pra enfrentar. Então seguir em frente. Vai ter obstáculos? É claro que vai. Tem um monte de lombada aí e todos os carros passam.

Entretanto, embora o reconhecimento de que a lesão permitiu que pudessem perceber a vida de forma diferenciada, coisa que consideraram um grande benefício, ela também representa a perda de uma vida que propiciava uma maior independência e autonomia. A perda da independência é uma questão importante, já ressaltada anteriormente, e que pode se tornar complicadora na vida destas pessoas. Os participantes desta pesquisa não se consideram completamente dependentes, conforme indica a tabela 13, mas admitem possuírem dificuldades estabelecidas a partir da necessidade de ajuda para realizar algumas atividades. Esta semi-independência pode ser exemplificada no seguinte depoimento:

Pessoa 6: Eu sei o que é acordar, não poder levantar, você precisar de alguém pra tomar banho, auxiliar certas coisas, você precisar de alguém pra catar as coisas dentro de um guarda-roupa, ter que pedir... você sabe que tanta coisa tem que precisar de alguém pra tá junto. Porque quem tá de fora, quem tá junto, tem uma certa, pequenina noção do que é 
isso aqui. Uma certa e pequenina noção. Quem vive só sabe. Sou bonitão, brincalhão, não sei o que... tá, mas vem viver isso aqui, pra você ver... é difícil!

De acordo com suas falas, a dependência não chega a impedí-los de realizarem muitas atividades comuns ao dia-dia. Relatam que esta semi-dependência não os impossibilita de continuarem realizando tudo que fazia parte de suas vidas antes de se tornarem deficientes, embora com maiores dificuldades e necessitando de algum auxílio.Neste caso, algumas atividades trazem uma certa dificuldade para serem realizadas sem a ajuda de terceiros, como por exemplo, andar sem o auxílio de qualquer equipamento ou utensílio. Esta consciência pode ser visualizada nas seguintes declarações:

Pessoa 3: Só tem umas coisinhas assim, mas o restante eu não me vejo assim e não me sinto assim. Faço tudo que eu quero, só não faço mais, às vezes é porque eu não quero e às vezes é porque não tem mesmo mais o que fazer sozinho.

Em dois relatos, foi identificada uma percepção de si mesmos, como pessoas completamente independentes (tabela 13). O depoimento abaixo ilustra este ponto de vista:

Pessoa 6: Completamente independente. 99.98 vírgula trinta. Esse restante aí é o caminhar, só. Eu me considero uma pessoa independente. Não diga o que eu não sou capaz, apenas mande fazer, porque eu nunca vou, ah, pedir pro cara fazer aquilo, porque tem aquilo, tem cadeira assim, tem degrau, tem... não quero saber! Sou completamente independente. E eu busco isso.

Percebe-se, a partir de seus depoimentos, que o conceito de dependência e independência assume variações de pessoa para pessoa, e até mesmo de acordo com o momento em que uma mesma pessoa se encontra. Gignac e Cott (1998), a partir de um estudo sobre os conceitos de dependência e independência, realizado com pessoas acometidas por doenças físicas crônicas e deficiências, constataram que estes construtos possuem determinações múltiplas, de forma que alguém pode se considerar independente e ao mesmo tempo se sentir dependente no que se refere a algumas implicações sociais. A consideração de uma 
semi-independência coloca em evidência a possibilidade de uma dependência exclusivamente voltada para algumas atividades físicas. Já em relação às conceptualizações relativas à independência, ocorre uma ênfase na capacidade de realizar escolhas, além da existência de um controle e direcionamento sobre suas próprias vidas. Este conceito de independência não exclui, necessariamente, a possibilidade desta pessoa necessitar da ajuda e auxílio de outras pessoas ou de mecanismos de assistência (VASH, 1988). Brow (1996), quando se refere ao trabalho de alguns Centros de Saúde voltados para a reabilitação de pessoas com lesão medular, chama a atenção para a obtenção de uma independência para que se estenda não só aos aspectos físicos, mas também emocionais, de modo que elas possam interagir em seu meio ambiente, mantendo suas habilidades sociais $\mathrm{e}$ relacionamentos pessoais de maneira saudável. Esta capacidade é considerada por esta autora como uma condição importante para a conquista de uma vida independente. Para De Jong (1979), quatro componentes são necessários para uma maior independência entre pessoas com uma patologia incapacitante. Seriam eles: a percepção de controle sobre suas próprias vidas; a habilitação para superar suas dificuldades físicas, considerando suas capacidades ainda existentes; a auto-confiança em relação a estas capacidades e, finalmente, a adaptação na acessibilidade e acolhimento dos deficientes nos ambientes externos no que se refere aos aspectos físicos e sociais.

Nos relatos analisados, observa-se a valorização de um comportamento no qual prevalece o poder da vontade, da iniciativa e da crença na possibilidade de superar os obstáculos, já que percebem as melhorias alcançadas como provenientes, principalmente, de suas atitudes e esforços, visando alguma recuperação, como foi mostrado anteriormente nos dados da tabela 5. Pode-se inferir, entretanto, a inexistência de uma percepção de controle total sobre suas próprias vidas, já que enfatizaram a dependência como um dos piores problemas enfrentados por eles, como vista na tabela 10. Estas pessoas se consideram semiindependentes e não completamente independentes, exceto no caso de dois dos relatos, o que reafirma a necessidade de uma maior autonomia por parte dos entrevistados.

Embora estas pessoas apresentem, como algumas de suas principais dificuldades, o condicionamento e estrutura física, foi constatado, em seus relatos, uma habilitação para 
superar tais dificuldades no momento em que eles apontaram para buscas de alternativas e de reestruturação de seus estilos de vida. Quanto as formas de enfrentamento, também, foi constatado um comportamento marcado pela busca de superação de suas dificuldades físicas, por meio da utilização de um suporte profissional, já que apontaram um investimento significativo em seu processo reabilitacional (tabela 8). $\mathrm{O}$ acolhimento do deficiente nos ambientes sociais, de uma forma geral, é um aspecto considerado pelos entrevistados como algo que ainda necessita ser conquistado, já que é apontado como uma das principais necessidades desta parcela da população, conforme explicitado na tabela 12 . A vida social e profissional dos entrevistados são abordadas no próximo bloco temático.

\subsection{Bloco Temático 2: Quanto a vida social, estudos e trabalho}

A forma como os participantes desta pesquisa entendem sua vida social é ilustrada na tabela 14.

Tabela 14. Considerações sobre sua vida social.

\begin{tabular}{|c|c|c|c|}
\hline & VIDA SOCIAL & $\mathbf{P}$ & $\mathbf{F}$ \\
\hline \multirow{4}{*}{ 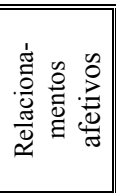 } & $\begin{array}{c}\text { relacionamentos sociais e } \\
\text { amizades }\end{array}$ & $1,2,4,5,6,9,10,11$ & 08 \\
\hline & vida em família & 2,3 & 02 \\
\hline & namoros e casamentos & 2 & 01 \\
\hline & & Subtotal & 11 \\
\hline \multirow{3}{*}{\multicolumn{2}{|c|}{ atividades de lazer }} & $1,2,9,11,12$ & 05 \\
\hline & & Subtotal & 05 \\
\hline & & Total & 16 \\
\hline
\end{tabular}

Quando questionados sobre sua vida social, os entrevistados se referem primeiramente aos relacionamentos afetivos, que se constituem de relações sociais e de amizade (5 relatos); seguido por vida em família (2 relatos), e, com apenas um relato, namoros e casamentos. Também se referem às atividades de lazer ( 5 relatos), como fazendo parte de suas vidas sociais. A maneira como avaliam sua vida social encontra-se explícita na tabela 15 .

\begin{tabular}{|c|c|c|}
\hline AVALIAÇÃO & $\mathbf{P}$ & $\mathbf{F}$ \\
\hline normal & $2,7,9,12$ & 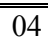 \\
\hline boa & $1,2,4$ & 03 \\
\hline muito boa & 3 & 01 \\
\hline ótima & 2 & 01 \\
\hline muito prazerosa & 3 & 01 \\
\hline ativa & 1 & 01 \\
\hline \multirow[t]{2}{*}{ inexistente } & 6 & 01 \\
\hline & Total & 12 \\
\hline
\end{tabular}


A tabela 15 revela a avaliação que os entrevistados realizaram sobre sua vida social. Na sua maior parte ela é concebida como normal e boa. No relato abaixo, pode-se constatar tal avaliação:

Pessoa 2: Normalmente. Eu saio, me divirto, conheço outras pessoas, namoro, fico... normal

Um dos relatos, entretanto, revela a inexistência de uma vida social. Ele pode ser contemplado a seguir:

Pessoa 6: não digo amigos, amigos não existem! Amigo é teu esposo, teu pai, tua mãe...são teus amigos. $O$ resto é detalhe.

Esta avaliação, presente no relato acima, pode estar associada às mudanças sociais observadas na vida desta pessoa ao se tornar portadora de uma deficiência física, como pode ser observado no seguinte relato:

Pessoa 6: Os meus amigos, pelo menos dois que estavam comigo, não foram nem na minha casa meu. Nem ligaram! Os outros, me encontram de vez em quando, e falam: Ah, tudo bom, não sei o que e acabou. Lá no prédio sim. A gente tem uma turma, vai lá, conversa, vida normal!

Nota-se que, mesmo não admitindo totalmente, as mudanças ocorrem alterando, drasticamente, o cotidiano, como pode-se notar na tabela 16. A partir dos resultados explicitados na referida tabela, pode-se inferir que as amizades constituem-se em um tema bastante significativo para estas pessoas quando são impelidas a falar sobre sua vida social. Eles destacam as mudanças ocorridas nas relações de amizade, a partir do advento da lesão medular, caracterizadas por uma descontinuidade. De forma que é possível distinguir uma cisão ocorrida em seus vínculos de amizade, com a ocorrência da lesão. Há uma diferença nítida nos relacionamentos configurados antes da lesão e após a mesma. 
Tabela 16. Mudanças sociais motivadas pela lesão medular.

\begin{tabular}{|c|c|c|c|c|}
\hline \multicolumn{2}{|c|}{ MUDANÇA } & $\begin{array}{c}\text { DESCRIÇÃO } \\
\end{array}$ & $\mathbf{P}$ & $\mathbf{F}$ \\
\hline \multirow{6}{*}{ 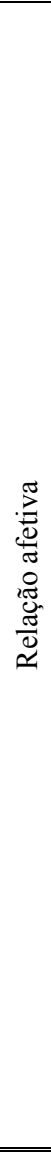 } & 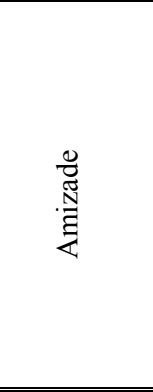 & $\begin{array}{c}\text { afastamento de alguns amigos } \\
\text { maior seletividade quanto aos amigos } \\
\text { maior proximidade e interesse de alguns amigos } \\
\text { formação de novos amigos } \\
\text { indiferença dos amigos } \\
\text { afastamento dos amigos somente no início } \\
\text { formação de amizades mais duradouras } \\
\text { relacionamentos mais superficiais } \\
\text { maior proximidade somente no início } \\
\text { não houve mudanças }\end{array}$ & $\begin{array}{c}1,2,3,4,5,8 \\
1,5,8 \\
1,4 \\
4,8 \\
6 \\
4 \\
1 \\
9 \\
1 \\
5 \\
\text { Subtotal } \\
\end{array}$ & $\begin{array}{l}06 \\
03 \\
02 \\
02 \\
01 \\
01 \\
01 \\
01 \\
01 \\
01 \\
19 \\
\end{array}$ \\
\hline & \multirow{3}{*}{ 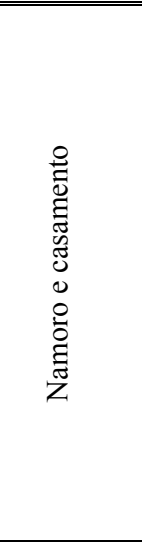 } & $\begin{array}{l}\text { maior dificuldade de estabelecer vínculos } \\
\text { dificuldade de manter vínculos } \\
\text { estranhamento do parceiro (a) nos primeiros anos } \\
\text { maior seletividade quanto aos parceiros (as) } \\
\text { maior dependência do parceiro (a) } \\
\text { problemas conjugais (conflitos) }\end{array}$ & $\begin{array}{c}3,7,9 \\
10,11 \\
4 \\
6 \\
8 \\
8 \\
\text { Subtotal } \\
\end{array}$ & $\begin{array}{l}03 \\
02 \\
01 \\
01 \\
01 \\
01 \\
09\end{array}$ \\
\hline & & \begin{tabular}{|} 
diminuição na auto-estima \\
problemas conjugais \\
estímulo ao exercício da sexualidade \\
dificuldade em estabelecer vínculo \\
instabilidade emocional \\
inexistência de mudanças relacionais
\end{tabular} & $\begin{array}{c}3,11 \\
11,12 \\
3 \\
12 \\
11 \\
3 \\
\text { Subtotal } \\
\end{array}$ & $\begin{array}{l}02 \\
02 \\
01 \\
01 \\
01 \\
01 \\
08 \\
\end{array}$ \\
\hline & & & Subtotal & 17 \\
\hline & $\begin{array}{l}\text { Relação } \\
\text { familiar }\end{array}$ & $\begin{array}{c}\text { maior dedicação e carinho por parte da família } \\
\text { maior dedicação a família } \\
\text { não houve mudanças } \\
\text { maior estabilidade familiar }\end{array}$ & $\begin{array}{l}3,7 \\
8,11 \\
3 \\
8 \\
\text { Subtotal } \\
\end{array}$ & $\begin{array}{l}02 \\
02 \\
01 \\
01 \\
06\end{array}$ \\
\hline & & & Subtotal & 42 \\
\hline \multicolumn{2}{|c|}{$\begin{array}{l}\text { Vida social como } \\
\text { um todo }\end{array}$} & $\begin{array}{c}\text { mudanças em seus hábitos sociais } \\
\text { dificuldade em ter vida social } \\
\text { não houve mudança }\end{array}$ & $\begin{array}{c}6,7,8,9,11 \\
10,11,12 \\
1,4,9 \\
\text { Subtotal } \\
\end{array}$ & $\begin{array}{l}05 \\
03 \\
03 \\
11\end{array}$ \\
\hline \multicolumn{2}{|c|}{$\begin{array}{l}\text { Comportamento } \\
\text { social }\end{array}$} & $\begin{array}{l}\text { uma maior "carência" social e afetiva } \\
\text { maior apego as pessoas } \\
\text { necessidade de se impor socialmente } \\
\text { (maior socialização) } \\
\text { dificuldade de interação }\end{array}$ & $\begin{array}{c}3,5 \\
5 \\
2 \\
10 \\
\text { Subtotal } \\
\end{array}$ & $\begin{array}{l}01 \\
01 \\
05\end{array}$ \\
\hline \multicolumn{2}{|c|}{$\begin{array}{l}\text { Atividade de lazer } \\
\text { e inserção social }\end{array}$} & $\begin{array}{c}\text { maior dependência de terceiros } \\
\text { não houve mudanças }\end{array}$ & $\begin{array}{l}3,5 \\
2 \\
\text { Subtotal }\end{array}$ & $\begin{array}{l}02 \\
01 \\
03\end{array}$ \\
\hline
\end{tabular}

Na maior parte dos relatos, eles descrevem o afastamento definitivo dos amigos, como pode ser confirmado nos depoimentos abaixo: 
Pessoa 5: Então, os amigos, entre aspas lá, quando souberam que eu estava numa cadeira de rodas, que eu não podia participar das atividades deles lá, tomar cerveja, pagodar, aquele negócio todo lá, então eles se afastaram.

Pessoa 4: Porque quando você é uma pessoa normal você tem um convívio normal com as pessoas, e de repente, esse é o meu caso, eu sofri o acidente, eu tive vários amigos que se afastaram por não saber lidar com a situação.

A lesão medular é, muitas vezes, considerada o motivo para o distanciamento das pessoas com que eles conviviam anteriormente, como pode ser percebido em seus relatos:

Pessoa 1: Eu tenho um colega que ele não foi me ver né? Ele foi lá na fisioterapia me pedir desculpa, me desculpa, mas eu não tenho coragem de ir te ver sentado nesta cadeira, eu sempre vi você pra cima e pra baixo, brincando... Ai eu falei: Olha brincando eu estou... mas ele falou: É eu, não achei legal. Aí eu falei: Tudo bem é uma opinião sua eu respeito né, quando quiser ir lá em casa pode ir, não tem problema né? Mas ele tá sempre perguntando por mim e tudo.

Pessoa 4: Às vezes as pessoas ficam... não é a pessoa que fica chateada, elas acham que eu tô chateado porque tem que dois garçons pegar na cadeira, ajudar pra subir. Não, eu levo numa boa, as pessoas que ficam observando né? Mais por curiosidade porque é difícil você vê um deficiente físico na rua... senão as pessoas não olhariam assim com tanta dificuldade... eu acho que se os deficientes saissem mais, até os lugares seriam mais adaptados

Nos relatos acima, são retratadas as dificuldades das pessoas de lidar com a deficiência caracterizada pela lesão medular. Os limites neste caso se colocam, não pela deficiência, mas, sim, pela visão social de que não é possível ao deficiente físico ter uma vida social e pessoal feliz. Franco (2002) constatou em seus estudos sobre a cegueira adquirida, o quanto a pessoa acometida por uma deficiência pode estar sujeita a concepções como as de incapacidade, dependência e inutilidade. A afirmação apresentada no relato de P4, denota 
que tais dificuldades de se lidar com a deficiência, assim como as concepções estigmatizantes associadas à mesma ocorrem por esta deficiência ser considerada ainda uma incógnita, algo não tão comum ao dia-dia dessas pessoas e, por isso, o desconhecimento e mesmo a falta de estrutura arquitetônica para atender às necessidades desta parcela da população. Ainda analisando este contexto, fica claro, em sua fala, o ponto de vista de que o próprio deficiente tem um papel fundamental para uma maior conscientização e esclarecimento da população, de uma forma geral. Ele deve estar presente nos ambientes sociais, de maneira que o mesmo possa assegurar o seu lugar na sociedade. Em outros relatos, o afastamento dos amigos é visto como algo normal, devido aos compromissos de uma vida comum:

Pessoa 3: Naquela época que eu precisava de um carinho, de um apoio, de uma pala amiga, dos meus amigos que sempre tavam comigo na hora boa...e eu tive tudo isso naquela época. Só que depois cada um tem a sua vida. Eles não podiam deixar da vida deles pra poder ficar comigo. Então não tinha como falar: não, você não vai trabalhar porque você vai ficar aqui comigo na minha casa, conversando. Como é que eles iam sobreviver, se sustentar? Não tinha como. Então eu comecei a me sentir isolado. Então eu comecei devagarzinho a ficar na frente da minha casa. Não abria o portão, ficava ali no portão olhando a rua, ai de repente passou um amigo, cumprimentou, passou outro...

Isto mostra uma consciência de que as mudanças ocorrem na vida do deficiente e não daqueles que estão ao seu redor. Esta forma de pensar reafirma a necessidade destas pessoas de estarem buscando sua socialização, como é destacado no seguinte depoimento:

Pessoa 2: porque você não pode se limitar, ficar em casa com medo de encarar os outros. Eu costumo dizer assim: é encarar os olhares curiosos, sair e mostrar seu rostinho pra sociedade. É aquela história, se a pessoa que não tem conhecimento sobre alguém com deficiência, se todo dia ela vê aquela pessoa naquele local ela não vai mais perceber, porque vai virar uma coisa tão cotidiana que ela vai deixar... então as pessoas tem que pegar e sair, mostrar que você, fazer parte da sociedade. E tem muitos deficientes ainda que eles ficam com medo de sair e encarar o mundo, encarar as pessoas, encarar a sua 
realidade. A partir do momento que você vê que essa realidade, que você não é a primeira e nem será a ultima, você consegue viver e fazer amizades.

Os relacionamentos de namoro e casamento também são bastante comuns nos relatos dos entrevistados (8 relatos) e se encontram relacionados com o comportamento das pessoas que se propõem a estar com eles ou com o seu próprio comportamento. As modificações ocorridas na sexualidade e nos vínculos amorosos, a partir da lesão medular, são muito comuns nestes casos. Anderson e Kitchen (2000) alertam para o fato de que somente muito recentemente tem havido iniciativas no sentido de oferecimento, pelos estabelecimentos de saúde e educacionais, de um suporte e orientação sexual às pessoas com alguma deficiência manifesta, seja ela orgânica, física, mental, sensorial ou perceptiva. Além disto, eles também ressaltam o caráter médico dessas práticas, levando em consideração o que é interessante para aqueles que o estão oferecendo e não para os usuários deste serviço. Observa-se que as disfunções sexuais são citadas por essa população como algo que afeta tanto o deficiente na sua auto-estima e situação emocional, como também os seus cônjuges, como pode ser visto em algumas de suas falas:

Pessoa 3: A relação entre homem e mulher, tanto amorosa quanto física, depois do acidente muda bastante, pelo lado, no caso, da mulher. E também pelo lado do homem, porque o homem às vezes se sente inferior e por não conseguir atingir aquela virilidade com a mulher, aquela coisa toda e acaba ele próprio se chateando, ele próprio se denegrindo pelo fato daquela coisa machista.

Entretanto, os entrevistados enfatizam que estas interferências são provenientes de uma concepção cultural onde a sexualidade do homem encontra-se interligada a uma complexidade de comportamentos e reações pré-estabelecidas e estipuladas socialmente. Os entrevistados revelam, ainda, que as modificações físicas decorrentes da lesão medular não impedem que continuem tendo os sentimentos de desejo e atração física, no entanto, faz-se necessária a utilização de recursos para a execução do ato sexual, mostrando-se nem sempre eficazes, que podem comprometer o exercício de um relacionamento estável com seus parceiros (as), como é declarado nos depoimentos que se seguem: 
Pessoa 3: Em outros termos eu não posso dizer que mudou, em termos de homem e mulher, relacionamento não mudou. Graças a Deus continua sendo do mesmo jeito, tenho as minhas necessidades, tenho os meus desejos e ela também tem e a gente se completa... Então não muda nada. Não muda numa relação, na atração física mesmo. Isso não muda, pelo menos no meu caso.

Pessoa 12: Na vida afetiva eu percebi mudanças porque com essa lesão pra mim ter uma relação sexual eu preciso de medicamentos né. Então uma relação normal, já dificulta a relação. Você fica com receio de se envolver com alguém porque tem uma série de dificuldades. Aí interfere né.

A ajuda e compreensão da parceira ou parceiro são fatores considerados essenciais para que o deficiente possa atingir uma realização sexual e amorosa. A experiência de um relacionamento amoroso, após a ocorrência da lesão, é apontada por esta população como algo muito importante em todos os aspectos de suas vidas, como se pode perceber nos relatos abaixo:

Pessoa 3: Ela vai em todo lugar comigo, então ela ta sempre do meu lado, sempre me ajudando... Porque a mulher, nesse caso, quando ela gosta mesmo do homem, mesmo ele sendo deficiente, ela vai ajudar, ela não vai atrapalhar.

Pessoa 6: Quando nós saímos, começamos a namorar no mesmo dia. Então, isso, precisava disso? Lógico! Deus fez o homem e a mulher. Entendeu? Foi muito bom, fez muito bem pra minha vida isso. Nossa! Porque o amor assim, não é sexo, é amor. A companhia, dar um beijo, dar um abraço... Isso é um complemento. Troca de carinho sabe, troca de abraços, troca de conversa, idéias... planos... isso é o amor!

Pode-se denotar, a partir destes depoimentos, um significado dado a seus relacionamentos amorosos que extrapola o simples prazer sexual. Eles indicam outros benefícios relacionados ao prazer de estar junto, de compartilhar idéias, planos e carinhos, que se 
tornam importantes neste tipo de relacionamento e que devem ser considerados como fatores essenciais na manutenção dos mesmos.

A discussão sobre a sexualidade, trazida por estas pessoas, não parece estar vinculada somente às relações sexuais em si, mas sim, envolve toda a complexidade que circunda este conceito. Embora considerando-se toda a importância dos aspectos psicossocias envolvidos na sexualidade destas pessoas, vários autores, ao investigar a incidência de publicações científicas abrangendo a sexualidade de pessoas com lesão medular entre os anos setenta e noventa, constataram uma ênfase nos aspectos fisiológicos desta questão, detendo-se nas características físicas e orgânicas da lesão medular, focalizando somente a extensão destes comprometimentos e não seus reflexos emocionais na vida sexual destas pessoas (BOLLER e FRANK, 1982; PAULA, 1993;). Denari (1997), enfatiza que estas pessoas, acometidas por uma deficiência física como a lesão medular, vem manifestando suas necessidades em relação a sexualidade de forma enfática, seja através de organizações ou associações voltadas para a conquista dos direitos dos deficientes, seja por meio de suas próprias reinvidicações e de suas famílias, junto aos espaços em que são atendidos (reabilitacionais, educacionais e etc), contribuindo assim, para um maior esclarecimento e desmistificação das idéias e concepções existentes que são, em grande parte das vezes, baseadas em falsos pressupostos. As mudanças observadas nos hábitos sociais, de uma forma geral, também são bastante enfatizadas em seus relatos, caracterizando-se como uma reestruturação de suas vidas no que se refere às atividades sociais. Tais mudanças podem ser percebidas no seguinte depoimento:

Pessoa 8: Alguma coisa mudou sim. Antes a minha vida era só trabalhar. Pra sair era a coisa mais dificil... ir em festa... sair pra passear, chegar final de ano, arrumar as coisas pra viajar, então, isso aí, minha vida era corrida,eu não tinha tempo pra essas coisas... então era mais trabalho.Hoje não, hoje eu não sei se é porque eu fico mais tempo dentro de casa, a gente sai, vai na casa de amigos nossos, é... viaja, final de ano a gente viajou, então muda um pouco, você tem tempo pra fazer essas coisas, coisa que a gente não tinha né. Não tinha tempo. Agora tem tempo, pra gente sair... 
A forma como estas pessoas compreendem o preconceito e os estigmas relacionados à lesão medular estão explicitados na tabela 17.

A tabela 17 mostra que os entrevistados, na sua maior parte, acreditam na existência de preconceito direcionado ao portador de lesão medular. Ela também aponta para o entendimento de que este preconceito tem origem, principalmente, no meio social e ocorre, na maioria das vezes, devido à dificuldade das pessoas de lidar com a deficiência. Reações sociais como o estranhamento e a indiferença em relação ao deficiente são citadas com freqüência em seus depoimentos ( 3 respostas cada uma) e podem ser observadas nos relatos que se seguem:

Pessoa 11: O pessoal vê, não conhece e acha aquilo estranho... então fica olhando, olhares curiosos...

Pessoa 9: É como muita gente receia né. Quando eu tô com a minha mãe, as pessoas não vem perguntar pra mim. É como se eu fosse débil mental... Pergunta pra minha mãe.

Embora o preconceito seja percebido como um fator complicador para sua vida social, as vivências sociais trazem um benefício e um aprendizado que se tornam muito importantes em suas vidas. É essencial para esta população, que o deficiente seja visto e reconhecido pela sociedade como um ser humano qualquer, com sentimentos comuns a todas as pessoas. Por este motivo, nada justifica que sejam tratados, percebidos de maneira diferenciada ou mesmo ignorados. No relato abaixo, este posicionamento é apresentado:

Pessoa 2: Não é porque você não anda que as pessoas vão te tratar sempre bem. Não, as vezes vai ter algum amigo que vai te falar um palavrão e você vai ter que responder, você vai ter que discutir... e isso eu acho maravilhoso, porque a pessoa não vai viver como uma... que não pode escutar as coisas e sempre vai ter que aceitar aquilo? Eu acho melhor assim. Não que eu goste de ouvir palavrão, mas assim de você tratar a pessoa como qualquer um. 
Tabela 17. Como percebem o preconceito/estigmas ligados à lesão medular.

\begin{tabular}{|c|c|c|c|c|c|}
\hline PERCEPÇÃO & FONTE & CAUSA & FORMA & $\mathbf{P}$ & $\mathbf{F}$ \\
\hline \multirow{31}{*}{ 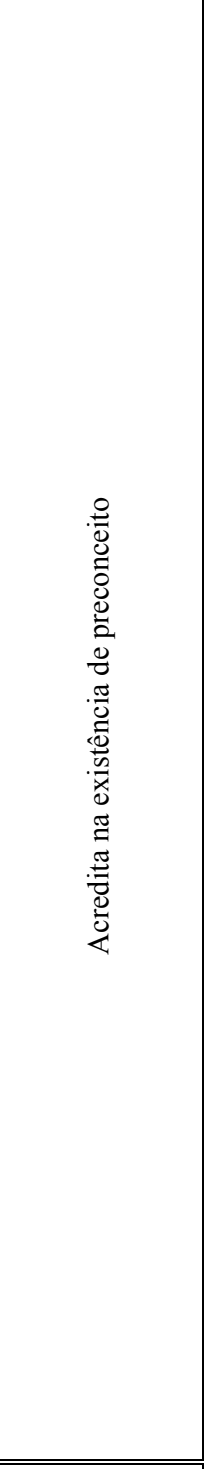 } & \multirow{13}{*}{$\begin{array}{l}\frac{\pi}{0} \\
0 \\
\mathscr{n}\end{array}$} & \multirow{6}{*}{$\begin{array}{l}\text { Dificuldade em } \\
\text { lidar com a } \\
\text { deficiência }\end{array}$} & estranhamento & $4,7,11$ & 03 \\
\hline & & & indiferença & $9,10,11$ & 03 \\
\hline & & & curiosidade & 11 & 01 \\
\hline & & & comentário pejorativo & 9 & 01 \\
\hline & & & cobrança (recuperação) & 8 & 01 \\
\hline & & & & Subtotal & 09 \\
\hline & & \multirow{5}{*}{$\begin{array}{l}\text { Reflexo de uma } \\
\text { sociedade } \\
\text { estigmatizadora }\end{array}$} & olhar de piedade & 8,12 & 02 \\
\hline & & & percepção distorcida do deficiente & 9 & 01 \\
\hline & & & olhar de desdém & 5 & 01 \\
\hline & & & \multirow[t]{2}{*}{ comentário pejorativo } & 9 & 01 \\
\hline & & & & Subtotal & 05 \\
\hline & & $\begin{array}{c}\text { Padrões sociais } \\
\text { de beleza e } \\
\text { perfeição } \\
\text { corporal } \\
\end{array}$ & \multirow[t]{2}{*}{ curiosidade } & $\begin{array}{c}3 \\
\text { Subtotal }\end{array}$ & 01 \\
\hline & & & & Subtotal & 15 \\
\hline & \multirow{10}{*}{ 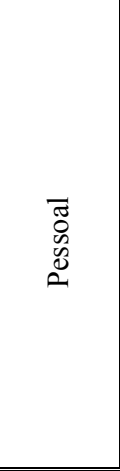 } & \multirow{4}{*}{$\begin{array}{l}\text { Não aceitação de } \\
\text { sua condição }\end{array}$} & auto-piedade & 3 & 01 \\
\hline & & & receio de não ser aceito & 3 & 01 \\
\hline & & & inferiorização & 3 & 01 \\
\hline & & & isolamento & 3 & 01 \\
\hline & & & & Subtotal & 04 \\
\hline & & \multirow{3}{*}{$\begin{array}{l}\text { Estigma vindo da } \\
\text { família }\end{array}$} & \multirow{3}{*}{$\begin{array}{c}\text { isolamento } \\
\text { dificuldade em se relacionar }\end{array}$} & 4 & 01 \\
\hline & & & & 4 & 01 \\
\hline & & & & Subtotal & \\
\hline & & Estigmas vindos & \multirow[t]{2}{*}{ sentimento de inferioridade } & 3 & 03 \\
\hline & & da sociedade & & Subtotal & 09 \\
\hline & \multirow{7}{*}{ 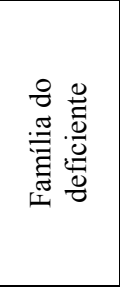 } & \multirow{6}{*}{ 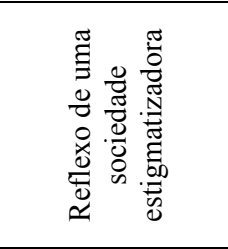 } & \multirow{6}{*}{$\begin{array}{c}\text { super-proteção. Ex: "sufoca" (P10) } \\
\text { isolamento do familiar deficiente. Ex: "esconde" } \\
\text { (P4) } \\
\text { comentário pejorativo } \\
\text { percepção distorcida do deficiente } \\
\text { indiferença }\end{array}$} & 4,9 & 02 \\
\hline & & & & 4 & 01 \\
\hline & & & & 9 & 01 \\
\hline & & & & 7 & 01 \\
\hline & & & & 11 & 01 \\
\hline & & & & Subtotal & 06 \\
\hline & & & & Subtotal & 06 \\
\hline & & & & Subtotal & 28 \\
\hline \multirow{10}{*}{ 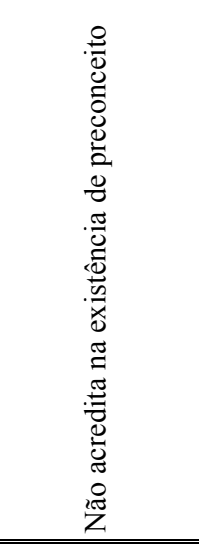 } & \multirow{10}{*}{$\begin{array}{l}\frac{\pi}{\pi} \\
\frac{\pi}{0} \\
\frac{\mathscr{J}}{0} \\
0 \\
\infty \\
\ll\end{array}$} & \multirow{4}{*}{$\begin{array}{l}\text { Falta de } \\
\text { informação }\end{array}$} & curiosidade & $2,3,4$ & 03 \\
\hline & & & receio (reações defensivas) & 4 & 01 \\
\hline & & & cobrança & 9 & 01 \\
\hline & & & não descreve & $\begin{array}{c}1 \\
\text { Subtotal }\end{array}$ & $\begin{array}{l}01 \\
06\end{array}$ \\
\hline & & \multirow{3}{*}{$\begin{array}{l}\text { Falta de } \\
\text { consciência } \\
\text { sobre a } \\
\text { capacidade real } \\
\text { do portador de } \\
\text { deficiência }\end{array}$} & \multirow{3}{*}{$\begin{array}{l}\text { percepção distorcida do deficiente } \\
\text { ausência de oportunidades de trabalho }\end{array}$} & 4 & 01 \\
\hline & & & & 2 & 01 \\
\hline & & & & Subtotal & 02 \\
\hline & & \multirow{2}{*}{$\begin{array}{l}\text { Dificuldade em } \\
\text { lidar com a } \\
\text { deficiência }\end{array}$} & \multirow[t]{2}{*}{ afastamento } & 4 & 01 \\
\hline & & & & Subtotal & 01 \\
\hline & & & & Subtotal & 09 \\
\hline & & & & Total & 37 \\
\hline
\end{tabular}


Pessoa 9: Porque muita gente cobra muito de quem tá na cadeira de rodas. Quem tá na cadeira de rodas tem que namorar... e você sabe que a situação em relação a namoro tá muito difícil. Quem tá na cadeira de rodas tem que trabalhar e o desemprego tá ai pra todo mundo. Quem tá na cadeira de rodas tem que andar rindo pra mostrar que tá bem, que não sente nada, mas não é por aí... Então a cobrança é, que você não pode rir, você não pode ficar séria! Falaram pra mim: você tem que rir mais, se soltar mais... e eu perguntei: porque? Não tô ouvindo nada engraçado, pra eu sorrir... e nem tô fazendo propaganda de creme dental... vou rir pra que? Então fica dificil, porque você não pode ficar rindo, você não pode ficar séria, você tem que trabalhar, você tem isso, você tem aquilo... mas não é por aí... você tem que fazer aquilo que você tá a fim e acabou e é isso que vale.

Nestes relatos observa-se que as expectativas que a sociedade possui em relação ao comportamento do deficiente também é uma questão importante, já que existe uma pré concepção de como a pessoa com uma determinada deficiência deverá agir perante o meio social. As exigências de passividade frente às outras pessoas baseiam-se na idéia de que os comportamentos de recusa ou indignação frente a qualquer situação, não remete a uma reação previsível a um ser humano comum mas, sim, deve sinalizar uma revolta vinculada a situação de patologia. Goffman (1988) chama a atenção para este fato, quando se refere às cobranças sociais vinculadas à condição de estigmatizado em que se encontram estas pessoas. O estigma, para este autor, carrega consigo uma série de comportamentos que são automaticamente esperados na pessoa a qual ele se refere, de forma que tais comportamentos tendem a ser encarados não como uma manifestação normal a sua condição de ser humano, mas sim, como uma expressão direta e necessariamente vinculada à deficiência. Portanto, quando suas reações são encaradas de forma natural, estas pessoas se sentem respeitadas. Outra tendência bastante comum nestes casos é considerar que o deficiente não é mais responsável pelos seus atos, como se a deficiência os tivesse debilitado mentalmente, como relatado por P9. A infantilização do deficiente físico é observada quando há uma negação da sua capacidade de se expressar e tomar decisões sobre sua própria vida. Em alguns casos, o direcionamento nas ações do deficiente também pode caracterizar o que Santos, L (2000) denomina "ajuda dominadora". Para esta autora, 
os cuidadores lançam mão do poder inserido no cuidar, e podem, desta forma, utilizar-se do mesmo para que a pessoa que está sendo cuidada torne-se prisioneira das vontades destes ajudantes, abdicando assim de suas próprias vontades e ou opiniões. Nos relatos seguintes é, também, claramente apontada a consciência dos entrevistados sobre a importância de uma maior autonomia, não somente nas suas ações, mas também nos seus desejos:

Pessoa 2: Então muitas pessoas podem chegar e falar pra você: olha, ande por ali, mas você que ta na cadeira de rodas é que vai saber se ali é o melhor lugar pra se passar e não a pessoa que ta andando

Pessoa 2: Quando eu sofri meu acidente, eu era criança e tudo, e as pessoas sempre perguntavam pra minha mãe: Qual é o problema dela? O que ela teve? Então chegou uma época que eu pensei: Puxa porque perguntam pra minha mãe? Se eu tenho voz eu posso falar. Dai que eu comecei a falar não, eu sofri um acidente e tal... ai eu comecei a contar a minha vida e as pessoas começaram a olhar pra mim e não pras pessoas que estavam do meu lado

Neste caso está claramente explícita a tentativa de P2 de reverter esta posição de passividade e de impossibilidade e de "ter voz", onde o deficiente é muitas vezes colocado no decorrer dos seus relacionamentos sociais, denunciando comportamentos estigmatizadores. (GOFFMANN, 1988).

Observa-se, com menor freqüência, a negação da existência do preconceito, associada com a afirmação da existência de comportamentos advindos do meio social, considerados por eles inadequados. Para estas pessoas, os comportamentos sociais frente a uma deficiência, podem estar relacionados a motivos diversos, como por exemplo, a falta de informação da sociedade sobre a deficiência e suas características, a curiosidade ou não compreensão e mesmo a não aceitação da ocorrência da deficiência, como pode ser visto nas seguintes falas:

Pessoa 1: Eu não diria preconceito, mas falta de informação bastante 
Pessoa 3: Existe sim aquela curiosidade da pessoa passar, ficar olhando, nossa... o que será que aconteceu com aquela pessoa? Então existe aquela curiosidade do pessoal olhar e falar: Pôxa, o que será que aconteceu com ele, um rapaz jovem, na cadeira de rodas... Então existe aquela curiosidade né? O que você ta fazendo aí? O que aconteceu com você?

Queiroz (1995) lembra que a própria palavra pré-conceito remete a um desconhecimento sobre a questão a que se refere. Trata-se de um juízo preestabelecido e baseado em opiniões, sem o devido aprofundamento em relação à realidade sobre a qual elas se manifestam.

É possível, entretanto, depreender de grande parte de seus relatos, a não alusão à discriminação (na sua concepção mais negativa), como um acontecimento de fato e direto, onde poderia haver a identificação de culpados e vítimas, mas sim, como um sentimento, que poderia estar relacionado com a própria deficiência e o que ela representa. Há uma sensação de desvantagem em relação às outras pessoas não deficientes, vivenciada concreta e afetivamente por esta população, que se torna, muitas vezes, um empecilho para que se efetivem como seres sociais. Os depoimentos, abaixo, apontam para estas questões:

Pessoa 5: Não assim diretamente, eu me senti, pelos olhares né, não que eu tenha me aproximado de alguém que tenha feito isso comigo, mas eu senti pelos olhares, né?

Pessoa 2: Não sei se é discriminada, mas eu quero trabalhar e não tô tendo oportunidade. Não vejo como uma discriminação. Nunca fui barrada em qualquer local que eu fui, em alguma danceteria, nunca fui barrada... pelo contrário, me deram até a oportunidade deu chegar a ter a um acesso melhor do que as outras pessoas.Não sei se fui discriminada, eu acho que a falta da oportunidade em relação ao emprego que até agora não apareceu. Acho que o resto não, que eu lembre não.

Os modos como estas pessoas reagem ao se depararem com concepções preconceituosas ou estigmatizantes sobre a pessoa com lesão medular, estão identificadas na tabela 18 . 
Tabela 18. Reações dos entrevistados ao preconceito social.

\begin{tabular}{|c|c|c|}
\hline REAÇÃO & $\mathbf{P}$ & $\mathbf{F}$ \\
\hline $\begin{array}{l}\text { ignora as reações preconceituosas e continua } \\
\text { a vida }\end{array}$ & $2,5,6,8,9,10$ & 06 \\
\hline assume o papel de conscientizador & $2,6,9,11$ & 04 \\
\hline rejeita estigmas (atitude defensiva) & $4,6,7,12$ & 04 \\
\hline não se sente incomodado & $5,6,8,9$ & 04 \\
\hline impõe seus direitos & $2,5,9$ & 03 \\
\hline $\begin{array}{c}\text { torna-se agente motivador para outros } \\
\text { deficientes }\end{array}$ & 2,6 & 02 \\
\hline reage ironicamente & 10 & 01 \\
\hline \multirow[t]{2}{*}{ fica atônito, perplexo } & 9 & 01 \\
\hline & Total & 25 \\
\hline
\end{tabular}

A tabela 18 mostra que os estigmas relacionados à deficiência que se manifestam claramente no convívio social destas pessoas, podem tê-los atingido em algum momento, entretanto, não os atingem mais, como é visivelmente declarado nos relatos seguintes:

Pessoa 6: Mas eu vou ficar na minha casa lá reclamando da vida? Com esse mundo aí fora? Eu vou viver a vida! Tô vivendo a vida. Eu não aceito eu como deficiente. Isso aqui não é uma deficiência. Pra mim não, se pro mundo aí é, o mundo não paga as minhas contas.

Pessoa 2: Você pegar peraí: Eu vou ao shopping e todo mundo vai olhar, todo mundo olha. Mas você vai abaixar a cabeça? Não! Sorri e segue em frente. Todo mundo vai olhar mesmo, então... seja o centro das atenções né, seja a pop star né?

As diferentes formas de exclusão encontradas no momento em que um deficiente não consegue um espaço no mercado de trabalho, não consegue se locomover com sua cadeira pela precariedade das ruas e avenidas e etc, são fatores complicadores para uma participação e interação maior do deficiente na sociedade. Um ponto de vista destacado pelos entrevistados é de que a ocorrência de discriminação encontra-se diretamente relacionada com a postura assumida pela pessoa com lesão medular perante a sua própria patologia e perante as reações discriminatórias observadas em seu meio social. Este fato encontra-se presente em grande parte de seus discursos, como foi devidamente explicitado na tabela 17. 
Em menor número, estão aqueles relatos que mostram uma perplexidade diante das reações preconceituosas ou uma reação de descontração e ironia perante os comportamentos preconceituosos, como pode ser denotado no relato abaixo:

Pessoa 10: As vezes eu brinco... As vezes ficam olhando assim aí eu pergunto se ele quer um autógrafo.

Em contrapartida, eles afirmam que, apesar do preconceito com o deficiente ainda existir, está ocorrendo por parte da população, de uma forma geral, uma mudança na maneira de perceber e encarar o deficiente físico. Este ponto de vista é explicitado no seguinte depoimento:

Pessoa 5: Agora tá mudando... O preconceito, não vou te dizer que no ponto geral, cem por cento, mas na minha opinião, tá na faixa ai de uns cinqüenta por cento da população são preconceituosos e outras não. Então tem gente, os amigos que convivem comigo, que conhecem já a minha situação, não me encaram como deficiente físico. Me encaram como uma pessoa normal e até fazem brincadeira, me sacaneiam pra caramba, e eu levo numa boa, beleza, é isso aí.

Observa-se, neste depoimento, que a mudança na forma de perceber e até tratar o deficiente físico com lesão medular, ocorrerá a partir de uma convivência maior com as pessoas portadoras desta patologia. Por meio deste conhecimento e desta convivência, a deficiência deixa de ser o foco de atenção principal para dar lugar à pessoa, o indivíduo na sua essência. Segundo Queiroz (1995), a existência do preconceito está necessariamente relacionada com uma concepção pré-determinada e só relativizada, e posta à prova, a partir de um maior conhecimento. Tal conhecimento é absorvido durante a vivência real e concreta com o objeto a que se destina o preconceito.

Com o objetivo de compreender melhor como os participantes desta pesquisa percebiam a atuação de programas, associações e grupos de apoio ou representativos desta parcela da população (deficientes), e que se formam com o intuito de buscar melhores condições 
sociais para o deficiente físico e portador de lesão medular, foi analisada a participação destas pessoas nestes programas, bem como, a opinião que possuem em relação aos mesmos. Observou-se a existência, nesta população, de pessoas que não participam deste tipo de associação, que participam como usuários dos serviços que estes programas oferecem e, também, os que já participaram como atuantes na formação e funcionamento de tais associações, mas que se encontram impedidos no momento de continuarem participando. Em alguns casos, por não concordar com a filosofia imposta nestes grupos, por achá-los improdutivos e, em outros casos, pela impossibilidade de exercer uma participação ativa nestes estabelecimentos, ou ainda por achar desnecessária tal participação, como pode ser percebido no depoimento abaixo:

Pessoa 12: Eu acho que tem pessoas que precisam participar disso, eu acho que eu não preciso. Eu sei o que eu tenho, eu sei como eu tenho que me colocar, que me comportar..o que eu preciso são informações, porque eu adquiri uma condição melhor de vida, mas não que eu precise participar pra saber...eu sei das minhas limitações. Eu sei trabalhar com elas.

Ainda existem os que participam contribuindo financeiramente e sendo também usuários destes serviços. Os que são usuários de associações como essas se beneficiam de programas que se restringem às necessidades do deficiente (e não da sociedade como um todo), sempre voltados para suprir aquilo que não lhe é comumente oferecido na comunidade da qual faz parte. Pode-se citar, como exemplo, os programas de fisioterapia, de informação sobre sua patologia, grupos de dança, atendimento psicológico, tratamento odontológico, assistência jurídica e outros.

Percebe-se que os participantes desta pesquisa reconhecem o valor dessas associações, já que as mesmas oferecem a eles a oportunidade de conhecer melhor a sua deficiência e suas conseqüências, além de proporcionar uma maior interação social, como relatado por P11:

Pessoa 11: Eu acho muito importante viu...porque você pode passar alguma coisa sua pro seu próximo e pode adquirir também do seu próximo. Porque você pode ser o que você 
quiser, mas tem certas coisas que o seu próximo tem que você não tem. Então eu acho que não custa nada você tá em contato ali, fazendo parte ali, porque você tá vendo alguma coisa, você passa alguma coisa e você recebe também.

Outro aspecto ressaltado como importante, diz respeito ao apoio psicológico e orientação recebida nestes estabelecimentos:

Pessoa 9: Eu acho uma boa, acho que deve ajudar muita gente,porque orienta, porque quando você parte pra uma vida nova é tudo muito dificil né e uma associação dessas orienta..e você acaba conquistando o seu espaço.

Pessoa 2: Isso é bem legal pras pessoas que tem interesse em saber, porque as vezes você não tem uma informação, você nem sabe a altura que foi a sua lesão. Então lá eles mostram, eles procuram orientar a pessoa sobre qual é a sua lesão, tem a parte de psicólogo também que é muito importante. Às vezes as pessoas ficam muito deprimidas, revoltadas, então eles ajudam nisso também.

Pessoa 1: Eu digo na parte psicológica, como a ADD [Associação de Deficientes de São Paulo] de São Paulo, eu tenho uma colega que vai e ela mudou bastante do jeito que ela era, ela ficou melhor. Ela só passa lá por terapia. Tem uma terapia em grupo, ela falou pra mim de uma terapia em grupo...

Os entrevistados ressaltam ainda que a assistência prestada por estas associações deveria englobar não somente o deficiente físico, mas também, as pessoas que convivem com esta população. Outra necessidade citada diz respeito a um trabalho de conscientização e preparo da sociedade, por meio dessas associações, para atender as necessidades das pessoas com lesão medular. Estas perspectivas em relação aos programas de assistência ao deficiente físico podem ser exemplificadas no seguinte relato:

Pessoa 2: Eu acho muito interessante, muito importante, mas eu acho que deve ter a interação de outras pessoas, família, porque por mais que a família esteja presente com 
você ela não está na sua pele.. Então tem que ter uma interação entre estas pessoas porque dai é uma questão de trocas de informações. Eu acho bem legal, bem importante.

A preparação do deficiente para o mercado de trabalho, através da implantação de cursos profissionalizantes, também é citada como um dos objetivos que este tipo de associação deve ter, como é relatado neste depoimento:

Pessoa 4: Eu acho que uma boa associação, ela deveria dar cursos né? Cursos profissionalizantes, algumas outras coisas, ajudar o deficiente a chegar nesses cursos, pra que ele possa se manter sozinho.

Uma das preocupações observadas em suas falas, diz respeito ao preparo do deficiente para alcançar uma maior autonomia. Outro aspecto citado se refere à preocupação com a seriedade do trabalho desenvolvido nestas associações, assim como também com a filosofia implícita nestes programas. De acordo com os entrevistados, as associações devem ajudar o deficiente a se reintegrar socialmente e não a se fecharem dentro de um grupo, em que se sintam seguros e protegidos. Esta visão é marcada pela idéia de que o deficiente deve procurar conquistar o seu espaço na sociedade de maneira igualitária em relação aos nãodeficientes sendo, porém, respeitados nas suas necessidades. Pode-se compreender este ponto de vista através do seguinte relato:

Pessoa 4: Reintegrar o deficiente a sociedade né? Agora, se for aquela associação paternalista, que tá ali somente para esconder, eu acho que isso dai é péssimo pro deficiente. Eu acho que o deficiente deve se expor um pouco mais. Aparecer mais pra resolver alguns problemas dentro da sociedade.

Ações que não contemplam as necessidades da pessoa com deficiência são relatadas no depoimento que se segue: 
Pessoa 7: Eu achava bom, mas pra quem queria assim, não sei te explicar o caso mas pra quem só vive dentro daquilo, em função da deficiência, não tem muita opção, não tem o que fazer né...

O trabalho constitui-se em espaço privilegiado na formação e na manutenção de uma identidade social. Por meio do trabalho, a pessoa com lesão medular poderá estar definindo qual o seu papel social e reformulando, desta forma, a sua identidade como um todo. Por este motivo, a compreensão da repercussão de uma deficiência nas relações e realizações profissionais é fundamental para a análise dos participantes desta pesquisa. Entretanto, para uma compreensão mais ampla do deficiente físico e suas implicações no trabalho, é necessário considerar suas realidades psicossociais e as interações estabelecidas entre eles e o trabalho.

A partir de tal análise foi possível perceber como os participantes desta pesquisa vivenciavam as questões pertinentes aos aspectos profissionais, assim como, suas interações dentro deste contexto, levando em consideração a forma como definem o lugar por eles ocupado em uma sociedade onde o trabalho, a eficiência e as exigências de um padrão de produtividade aparecem corriqueiramente em suas vidas (ROCHA,1999). Os depoimentos que serão analisados, a seguir, mostram como estas pessoas lidam com estes pressupostos, o significado que o trabalho possui em suas vidas e como, de acordo com as suas concepções ou visões individuais, o deficiente é percebido dentro do ambiente de trabalho.

Conforme explicitado anteriormente, os aspectos relacionados à vida profissional e ocupacional dos participantes desta pesquisa, são apresentados nas próximas tabelas. A tabela 19 mostra o contexto em que os participantes desta pesquisa se inserem, no que diz respeito a sua formação escolar e atividades profissionais ou ocupacionais. 
Tabela 19. Situação de vida: nos estudos, vida profissional e ocupacional.

\begin{tabular}{|c|c|c|c|}
\hline SITUAÇÃO & CONTEÙDO & $\mathbf{P}$ & $\mathbf{F}$ \\
\hline \multirow{8}{*}{ 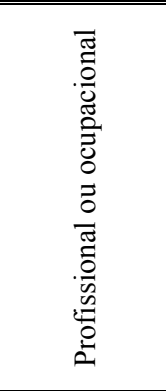 } & \multirow{8}{*}{\begin{tabular}{|c} 
parou de trabalhar \\
exerce atividade \\
profissional \\
exerce atividades \\
esporádicas \\
militar reformado \\
aposentado \\
desempregado \\
trabalhador \\
liberal
\end{tabular}} & $\bar{~} 1,9,10,11$ & 04 \\
\hline & & 3,4 & 02 \\
\hline & & 1,6 & 02 \\
\hline & & 5,6 & 02 \\
\hline & & 1,7 & 02 \\
\hline & & 2 & 01 \\
\hline & & 12 & 01 \\
\hline & & Subtotal & 14 \\
\hline \multirow{5}{*}{$\begin{array}{l}\text { Formação } \\
\text { escolar }\end{array}$} & \multirow{6}{*}{$\begin{array}{l}\text { parou de estudar } \\
\text { terminou os } \\
\text { estudos } \\
\text { continua } \\
\text { estudando } \\
\text { voltou a estudar }\end{array}$} & $\overline{11,5,6,7,9,11}$ & 06 \\
\hline & & $2,4,12$ & 03 \\
\hline & & 3 & 01 \\
\hline & & 10 & 01 \\
\hline & & Subtotal & 11 \\
\hline & & Total & 25 \\
\hline
\end{tabular}

A partir das informações contidas na tabela 19, percebe-se uma ocorrência maior de relatos que indicam a ausência de atividades profissionais ou ocupacionais. O exercício de atividades esporádicas aparece em dois dos relatos e refere-se às atividades que não se enquadram em um exercício profissional sistematizado, ao contrário das atividades profissionais, que aparecem com a mesma freqüência. Não obstante, estas atividades esporádicas, como por exemplo, a realização de palestras em instituições ou a atuação como auxiliar de escritório, podem ser consideradas como um trabalho muito importante e significativo no seu contexto de vida. O relato seguinte ilustra este fato:

Pessoa 6: É o meu trabalho. O meu trabalho o que é... Eu vou em todas as universidades de São Paulo, faculdade, universidades... o que você imaginar, parque da Polícia Militar, escolas, colégio militar... onde você imaginar que tem gente, muita gente, eu vou pra poder contar minha história. Que é um alerta pra muita gente e uma lição. Primeiramente um alerta e depois uma lição.

A situação de militar reformado aparece em dois dos relatos citados. Nestes casos, observase a cristalização de uma identidade profissional que os colocam na situação de militares, mesmo que não estejam exercendo as suas funções ocupacionais referentes a este cargo. O depoimento, abaixo, ilustra tal percepção: 
Pessoa 5: Eu tô vinculado no exército até hoje, eu não tô na ativa, eu tô na reserva, eu tô reformado devido ao acidente, mas estou ligado a ele, continuo na mesma patente que tinha antes, e a minha vida militar continua a mesma assim, burocraticamente eu continuo sendo militar.

Com um número menor de relatos, encontram-se referências à formação escolar, com três dos entrevistados com ensino superior completo, dois dando continuidade aos estudos e, com seis desistências, constituindo-se portanto da maioria.

Em praticamente todos os depoimentos apontados, é perceptível a importância para estas pessoas de estar exercendo alguma atividade, se não profissional, uma que se aproxime de uma possível realização profissional. Quando os que não se encontram exercendo alguma atividade profissional/ocupacional ou escolar foram questionados sobre os motivos de não estarem trabalhando ou estudando no momento, as respostas se diversificaram, de acordo com a história pessoal de cada um. Os motivos citados abordam um espectro onde a situação da pessoa com lesão medular frente às oportunidades de trabalho e estudos mostram-se bastante restritas. As justificativas que se referem ao advento da lesão medular e as mudanças trazidas por ela englobam os aspectos fisiológicos (limitações físicas, de locomoção, complicações hospitalares e tempo gasto com reabilitação), estruturais (limitações físico-geográficas), sociais (mudanças no status e no papel social exercido no trabalho) e materiais (dificuldades financeiras). A dificuldade financeira é um dos aspectos que dificultam o acesso do deficiente às faculdades ou instituições de ensino, conforme foi apontado em dois dos relatos, como um dos efeitos negativos provenientes da lesão medular (tabela 10) e como uma das dificuldades encontradas pela pessoa acometida pela lesão medular, na tabela 11. Esta consideração pode ser observada na fala, a seguir:

Pessoa 1: Primeiro porque ta um pouco cara a faculdade. Eu até pensei, mas eu fui ver os preços e por enquanto não tá dando não. Era faculdade particular e começou a ficar bem apertado e pra tudo é muito gasto. Qualquer coisinha que você vai procurar ou vai ver é muito gasto. 
As mudanças nas condições financeiras de pessoas portadoras de patologias crônicas, como a lesão medular, foram observadas em vários estudos realizados com esta população (LOUREIRO, FARO e CHAVES, 1997; MARTINS, FRANÇA e KIMURA,1996). Isto se deve aos inúmeros gastos com tratamento, dispositivos de auxílio e etc, que estas pessoas passam a ter em decorrência desta patologia (SANTOS, L. 2000).

Um outro aspecto relacionado diretamente à lesão medular e que impossibilita estas pessoas de exercerem uma atividade profissional, diz respeito às próprias limitações físicas impostas pela lesão. Para estas pessoas, algumas atividades profissionais e de formação passam a ser impossibilitadas, reduzindo desta forma, o leque de suas escolhas ou opções profissionais. Este fato pode ser observado nos seguintes relatos:

Pessoa 11: Eu só não estou estudando no momento por causa das condições das mãos. Que não tem como pegar em uma caneta. Não estou estudando por causa disso. Na minha situação é muito difícil. A não ser que tenha os acessos adequados né...no meu caso.

Pessoa 1: Parei porque o serviço que eu fazia lá, o que eu faço hoje quando eu apareço lá é outra coisa né? O serviço que eu fazia não dá pra fazer mais porque era mecânico diesel né? Mexia com caminhão, esse negócio não dá pra fazer mais. Por causa da lesão. Antes da lesão eu trabalhava durante o dia e estudava a noite.

Pessoa 3: Eu acho que se não tivesse a lesão, se eu não tivesse nessas condições, eu não teria esse trabalho. Eu continuaria como mecânico com o meu pai. Eu não teria outro estudo que senão o segundo grau completo. Seria não por aquele motivo assim: porque o pai quer, mas porque eu gosto mesmo. Eu gosto da mecânica. Eu tenho muita vontade de trabalhar com a mecânica. Eu acho muito gostoso.

Observa-se, nos depoimentos acima relatados, a importância que a ocorrência de uma patologia como a lesão medular pode ter na identidade profissional de uma pessoa. A partir do advento de uma lesão medular, suas escolhas profissionais passam a se restringir àquelas 
que lhe são possíveis. Planos devem ser reconsiderados e uma nova realidade passa a se sobrepor àquela vivida até então.

Aspectos fisiológicos relacionados com as repercussões físicas de uma lesão medular também foram citados como justificativa para as dificuldades no âmbito profissional. Isto pode ser visto em algumas de suas falas:

Pessoa 1: Eu parei no meio do curso. Por causa do acidente, foi durante o meu curso que eu sofri o acidente, aí eu tranquei matrícula e aí eu não voltei mais. Eu fiquei quarenta e seis dias internado. Hoje eu acho que não pode voltar mais. E também parei porque eu estou me dedicando a reabilitação.

Neste caso, o tempo gasto com reabilitação é um fator preponderante na sua vida profissional. A reabilitação passa a ter um espaço importante em suas vidas, tanto quanto ou, em alguns casos, mais importante que o trabalho em si. Isto revela um paradoxo, já que a reabilitação, neste caso, não exerce a função de reabilitar esta pessoa, também, no que diz respeito à sua atuação e identidade profissional.

Outra questão trazida em suas falas, como dificultadora para uma realização profissional, está relacionada com o despreparo das instituições de trabalho para receber e inserir o deficiente físico na sua estrutura espacial. A estrutura físico-espacial das instituições de ensino e as dificuldades de locomoção encontradas por estas pessoas, também são destacadas em seus depoimentos, nos quais são citadas as vantagens das adaptações arquitetônicas, dentro e fora dos ambientes educacionais e profissionais:

Pessoa 11: E também devido a minha situação, que no meu caso a minha esposa não dirige, tá tirando carta agora, então o acesso fica meio complicado.

Pessoa 2: Tenho amigos, mas quando se fala das firmas deles eles dizem: Ah o refeitório é alto lá, o restaurante é tudo alto! Não dá pra me servir sozinha, mas pode ter outra pessoa que possa fazer isso, mas as portas são de estrutura pesada que não dá pra uma cadeira, 
alguém com uma cadeira de rodas conseguir abrir, ou alguma coisa assim. Então tem que mudar toda a estrutura para que eu possa me sentir bem né? Conseguir ir e vir onde eu estiver trabalhando. Isso é o que eu tenho passado, o que eu tenho vivido, o que eu tenho como experiência.

Outra complicação ocorre na estrutura administrativa de funcionamento e de divisão de serviços das instituições de trabalho. Este fato é bastante visível no seguinte depoimento:

Pessoa 2: Bom, até agora só sai concurso pra ser professora, pra policial e tal, mas eu to analisando, procurando, lendo bastante jornal pra vê se encontro até pra prestar um concurso né?. É bem difícil né? Imagina, pros andantes é difícil pros cadeirantes mais ainda. Por mais que as pessoas falem que existe uma porcentagem, que qualquer empresa deve ceder, só que não é só deficiente físico, existe o visual, o auditivo...então eles preferem pegar pessoas com estes tipos de deficiências do que o fisico que tem que adaptar tudo. Banheiro, rampa, refeitório, restaurante...É triste isso porque é o valor que se dá. Não é a empresa pegar, não, tem que ver a pessoa como profissional. O que eu posso oferecer aquela empresa e não pela empresa se sentir obrigada a ta comigo. Não só pra mim, eu to colocando isso também para os outros deficientes, só que na minha condição eu to vendo isso como uma dificuldade. Porque hoje em dia quem eu conheço consegue emprego por indicação e infelizmente eu não tenho indicação.

No depoimento acima, são relatadas as dificuldades de conseguir se estabelecer profissionalmente, inerentes ao tipo de deficiência, no caso, à deficiência física, e à insegurança provinda do medo de conseguir uma colocação, somente para que a empresa esteja satisfazendo uma lei ${ }^{7}$ e não pela sua própria capacidade de trabalho. A repercussão da deficiência atuando com modificações no papel profissional e, na sua conseqüente representação social, aparece em outros depoimentos, onde as questões relativas ao status social e a representatividade pessoal de uma profissão ou de uma atividade profissional exercida anteriormente ao advento da lesão são fatores conclusivos na decisão de continuar ou não trabalhando, como pode ser percebido neste relato:

\footnotetext{
${ }^{7}$ Lei de Cotas $n^{\circ} 8213 / 91$ - Portaria MPAS n ${ }^{\circ} 4677 / 98$ que obriga empresas com mais de 100 (cem) funcionários a manterem de 2 a $5 \%$ de portadores de deficiência em seu quadro de funcionários.
} 
Pessoa 5: mas eu acho que não faria bem psicologicamente para a pessoa. Já pensou, de repente você é uma pessoa ativa e de repente tá numa cadeira de rodas, numa mesinha, batendo máquina e a rapaziada lá fazendo as atividades que você fazia antes, eu acho que em vez de fazer um bem pra você te faria mal, embora você tá no seu convívio lá, mas... faria mal porque psicologicamente, você seria afetado. Eu particularmente penso assim.

O receio de ser percebido de forma diferenciada é um outro aspecto citado em um de seus relatos a seguir:

Pessoa 11: E no meu caso, eu me misturar com as pessoas que são normais...as vezes no meu caso, alguém vai fazer uma brincadeirinha que vai te ofender né...

Observa-se, em algumas falas, a existência de planos profissionais que tiveram que ser abruptamente alterados devido à ocorrência da lesão medular, já destacados na tabela 9 . Neste depoimento, estes planos são relatados:

Pessoa 3: Porque antes do meu acidente eu tinha um projeto de vida, eu gostaria de ser piloto de caça aérea, aí como o acidente interrompeu justamente uma faixa etária que daria pra mim se inscrever, aí tive que optar por uma segunda opção que era a informática.

O significado do trabalho para estas pessoas irá apresentar variações, de acordo com a história e a vivência de cada uma e, também, das reações observadas frente a todas as limitações impostas pela deficiência, citadas anteriormente. No caso dos entrevistados, verificou-se que o trabalho encontra-se relacionado, na sua maior parte, ao aspecto pessoal.

Nestes casos, o trabalho pode despertar sentimentos como de orgulho e até mesmo de tristeza profunda, por não estar mais exercendo as atividades profissionais realizadas anteriormente ao advento da lesão. Entretanto, ele pode estar associado também, a uma realização profissional. Os relatos abaixo exemplificam alguns destes significados dados ao trabalho: 
Pessoa 10: Eu me sinto orgulhoso. É bom né...

Pessoa 3: É um dos serviços que na minha opinião, embora eu trabalhar com computador, pegar uma máquina que nem essa [apontou pro computador], desmontar, fazer ela funcionar é muito gratificante. Porque é sinal que você entendo o que você ta fazendo e é sinal que você não jogou o dinheiro fora fazendo o curso.

O trabalho também possui, em dos relatos, um significado social. Neste caso ele pode significar uma forma de interagir com as pessoas, assumir um caráter de status que proporciona a estas pessoas uma identidade profissional e uma qualificação perante à sociedade ou se apresentando como uma forma de exercer seu papel e sua responsabilidade social. No relato da Pessoa 3, observa-se que as responsabilidades assumidas com o trabalho em si ocupam um espaço importante na sua vida. Isto é mostrado claramente no seu depoimento:

Pessoa 3: Pra mim a minha preocupação é o povo. Desde uma vez que me puseram num cargo elevado que é pra tomar conta disso daí, eu vou até o fim. Todas as conseqüências... Eu cobrava direto, às vezes eu chegava dias de não subir diretamente pra comunidade e ficava na prefeitura no setor de compras, ali forçando até sair alguma coisa. Ligava pro fornecedor por conta, falava: ó não traz aqui que o prefeito liberou. Independente dele liberar. Levava xingo depois tá certo, mas eu não deixava a unidade... sempre mantinha mais ou menos a unidade equilibrada. Porque é um compromisso muito sério.

Concluindo, pode-se afirmar, a partir de seus depoimentos, que o trabalho ocupa um espaço muito importante na vida pessoal e profissional destas pessoas, estejam elas trabalhando no momento ou não. Faz-se também perceptível, em um dos relatos daqueles que não se encontram exercendo as funções profissionais que lhe cabiam anteriormente à lesão, a esperança de retornar, em algum momento, a exercer estas funções. 
Os obstáculos encontrados pelos entrevistados que se encontravam trabalhando e/ou estudando, ou os que já trabalharam e/ou estudaram na condição de deficientes, no seu ambiente de trabalho, estão contemplados na tabela 20.

Tabela 20. Obstáculos encontrados no trabalho.

\begin{tabular}{|c|c|c|c|c|}
\hline OBSTÁCULO & & CONTEÚDO & $\mathbf{P}$ & $\mathbf{F}$ \\
\hline \multirow{7}{*}{ 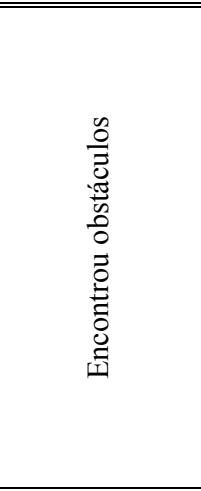 } & Físico/fisiológico & $\begin{array}{c}\text { locomoção } \\
\text { controle urinário e do esfíncter retal }\end{array}$ & $\begin{array}{c}3,4,12 \\
3 \\
\text { Subtotal }\end{array}$ & $\begin{array}{l}03 \\
01 \\
04\end{array}$ \\
\hline & Social & preconceito/estigma & $\begin{array}{l}2,4,6,10 \\
\text { Subtotal } \\
\end{array}$ & $\begin{array}{l}04 \\
04 \\
\end{array}$ \\
\hline & \multirow{2}{*}{ Pessoal } & $\begin{array}{l}\text { psicológicos: ansiedade, tensão, } \\
\text { preocupação }\end{array}$ & 3 & 01 \\
\hline & & de relacionamento & $\begin{array}{c}3 \\
\text { Subtotal } \\
\end{array}$ & $\begin{array}{l}01 \\
02 \\
\end{array}$ \\
\hline & \multirow[t]{2}{*}{ Ambiental } & $\begin{array}{l}\text { acessibilidade e adaptações } \\
\text { arquitetônicas } \\
\end{array}$ & 10 & 01 \\
\hline & & & Subtotal & 01 \\
\hline & & & Subtotal & 11 \\
\hline \multirow{5}{*}{ 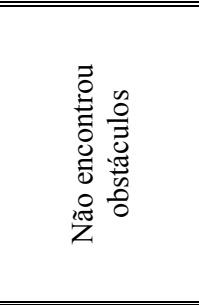 } & \multicolumn{2}{|r|}{ nenhum tipo } & $\begin{array}{l}1,3,4,6 \\
\text { Subtotal }\end{array}$ & $\begin{array}{l}04 \\
04\end{array}$ \\
\hline & \multirow[t]{2}{*}{ Ambiental } & \multirow[t]{2}{*}{$\begin{array}{l}\text { acessibilidade e adaptações } \\
\text { arquitetônicas }\end{array}$} & $2,4,6,7$ & 04 \\
\hline & & & Subtotal & 04 \\
\hline & Social & preconceito/estigma & $\begin{array}{c}10 \\
\text { Subtotal } \\
\end{array}$ & $\begin{array}{l}01 \\
01 \\
\end{array}$ \\
\hline & & & Subtotal & 09 \\
\hline & & & Total & 20 \\
\hline
\end{tabular}

Quando os que se encontram trabalhando no momento foram questionados sobre o fato de terem encontrado ou de encontrarem algum obstáculo para conseguirem estar estudando ou trabalhando, foram encontradas dificuldades em onze dos seus relatos. Estas dificuldades se referem, na sua maior parte, aos aspectos fisiológicos e sociais. As que abordam o aspecto fisiológico está exemplificada por meio do seguinte relato:

Pessoa 3: A dificuldade foi mais assim... o medo!. O medo de... como eu posso dizer...o receio quanto a necessidade fisiológica. Quanto a urinar, quanto a defecar...Isso foi um pouco, no começo, foi um pouco assim meio constrangedor pra mim. Eu ficava meio inseguro, meio com medo de repente tá dentro do serviço e ter algum problema, uma disfunção intestinal e acontecer um imprevisto e tá ali no meio dos amigos e aquela coisa toda... 
Outros aspectos que também aparecem com maior freqüência em seus relatos, diz respeito ao preconceito e à falta de informação sobre a lesão medular e suas conseqüências. Estes obstáculos vem ao encontro dos dados obtidos em relação à sua vida social, dos quais o preconceito e a falta de informação da população são aspectos bastante significativos (tabela 17). Estas reações sociais podem ou não ser compreendidas pelos entrevistados como um empecilho para suas realizações profissionais.

Os obstáculos pessoais que não se encontram necessariamente associados a uma deficiência, mas fazem parte do cotidiano de pessoas que estão inseridas em um ambiente profissional, estão citados como dificuldades de relacionamento, ansiedades, tensão e preocupação, aparecendo com menor incidência em seus depoimentos, assim como os problemas relacionados à acessibilidade (adaptações arquitetônicas). Uma grande parte dos entrevistados (4 respostas), no entanto, revelaram não ter enfrentado algum tipo de obstáculo. Já em outras quatro respostas, foi evidenciada a inexistência de obstáculos referentes à acessibilidade e adaptações arquitetônicas. E em apenas um dos relatos, não foi evidenciado os obstáculos referentes ao preconceito e estigmas.

Na tabela 21 são elucidadas as formas como os entrevistados reagem aos obstáculos encontrados no trabalho.

Tabela 21. Reações aos obstáculos encontrados no ambiente de trabalho.

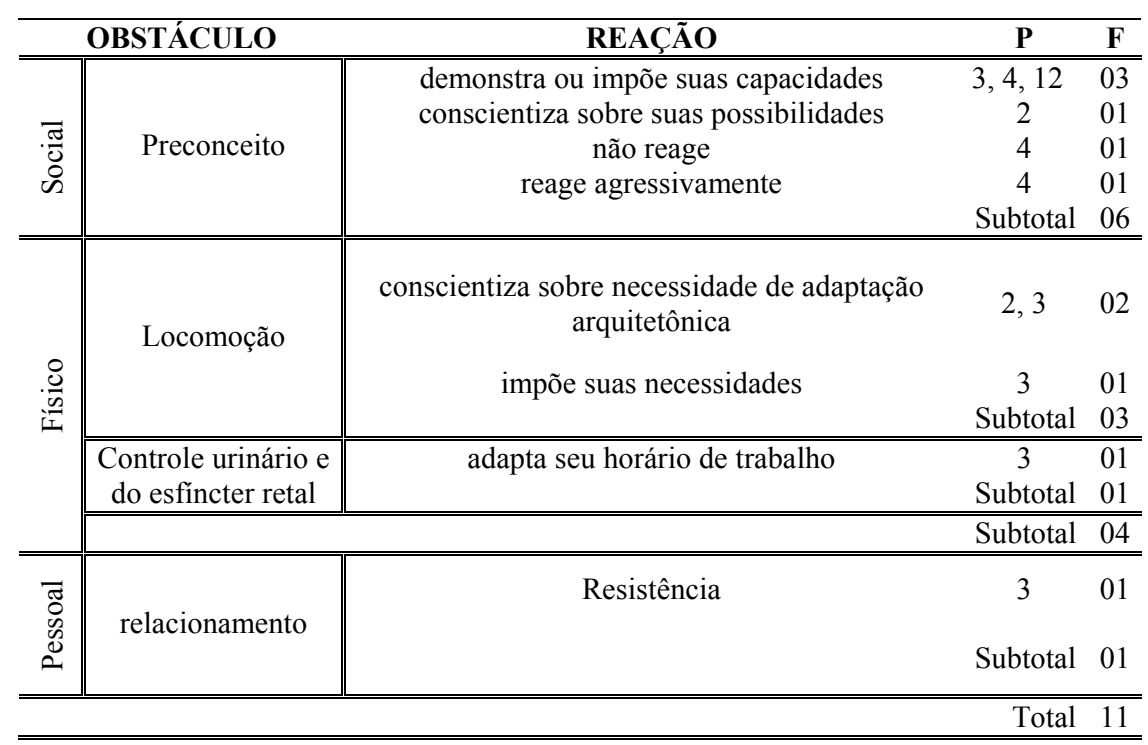


Conforme os dados apresentados na tabela 21, fica proeminente que as reações apontadas por estas pessoas se direcionam, principalmente, aos obstáculos sociais caracterizados pelos comportamentos estigmatizadores daqueles com quem elas convivem em seu ambiente de trabalho. Na maioria das vezes, elas reagem mostrando suas capacidades e não negando as suas limitações, mas enfatizando as possibilidades de superá-las e viver normalmente. Lutam para serem vistas como pessoas e não como deficientes ou incapazes. A percepção de sua capacidade de superar as dificuldades e aprender a lidar com elas adequadamente é muito importante para estas pessoas, pois isto trará novos estímulos para conseguir adequar suas necessidades físicas às necessidades exigidas por seu trabalho e estudos. As reações apontadas na tabela 21 coincidem, com algumas das suas reações ao preconceito social, apresentadas na tabela 18. Alguns de seus relatos podem exemplificar estas reações:

Pessoa 3: Tive muitas vezes, teve já de casos, eu entrei batendo de contra com uma pessoa que queria me tirar, já no primeiro mês, logo no primeiro mês eu tive uma pessoa que queria puxar meu tapete mas eu fui mais forte do que ele, não dei moleza pro cara, bati de contra com ele, mostrei a prova de a mais b de que não era eu que tava sendo errado, era ele, até que passei pelo teste.

Pessoa 2: Eu procuro passar pras pessoas que isso é pé. Minha cadeira de rodas são pernas rodas, porque com elas eu posso ir aonde eu quero em qualquer lugar, se tiver escada alguém me pega, se não tiver rampa... então é pra sair de casa. Isto é o que eu procuro passar. Obviamente que você sempre encontra nas estradas da vida pessoas que não tem informação, que não sabem porque a gente ta lá então vê a gente como coitado, mas isso é só você mexendo com a cabeça né?

Estão inseridas em suas falas, as percepções, por parte dos entrevistados, que a forma como eles são vistos socialmente não indicam, de maneira alguma, o que são ou o que podem realizar, já que a deficiência física não os impede de realizar muitas atividades essenciais em suas vidas, como por exemplo, o trabalho. As percepções que possuem sobre as influências de sua patologia nos ambientes de trabalho, são vislumbradas na tabela 22. 
Tabela 22. Influência da lesão medular no ambiente de trabalho, segundo a percepção dos entrevistados.

\begin{tabular}{|c|c|c|c|}
\hline INFLUENCIA & CONTEÚDO & $\mathbf{P}$ & $\mathbf{F}$ \\
\hline Não influencia & $\begin{array}{c}\text { na execução do trabalho } \\
\text { (é possível adaptar o trabalho ao deficiente) } \\
\text { no resultado do trabalho }\end{array}$ & $\begin{array}{c}1,2,4,7,8,10,11 \\
4,11,12 \\
\text { Subtotal }\end{array}$ & $\begin{array}{l}07 \\
03 \\
10\end{array}$ \\
\hline Positiva & $\begin{array}{c}\text { na execução do trabalho } \\
\text { no resultado do trabalho } \\
\text { para o deficiente: sente-se mais seguro }\end{array}$ & $\begin{array}{l}2,3,11 \\
3,11 \\
3 \text { Subtotal }\end{array}$ & $\begin{array}{l}03 \\
02 \\
01 \\
06\end{array}$ \\
\hline Negativa & $\begin{array}{c}\text { na execução do trabalho } \\
\text { na acessibilidade }\end{array}$ & $\begin{array}{l}1,4,12 \\
10,12 \\
\text { Subtotal }\end{array}$ & $\begin{array}{l}03 \\
02 \\
05\end{array}$ \\
\hline & & Total & 21 \\
\hline
\end{tabular}

De acordo com grande parte dos relatos (10), a deficiência física marcada pela lesão medular não interfere na vida profissional de uma pessoa, já que suas limitações, de acordo com esta amostra, não os impedem de trabalhar ou de exercer uma profissão de forma eficiente e bem feita, desde que esteja utilizando-se de recursos adaptativos, como é contemplado na fala abaixo:

Pessoa 1: Agora a pessoa pode partir para um outro campo que não vai interferir em nada. Pode ser até que ganhe mais, tenha uma renda muito maior em outro campo. Você tem outros caminhos que pode tá partindo. Hoje eu teria que fazer alguma coisa relacionada a projetos que eu pudesse não tá mais mexendo, mais estar desenvolvendo. Tem serviços que a pessoa vai ta executando igual a qualquer profissional. Outro dia eu tava vendo uma reportagem onde médicos cadeirantes estavam operando... ele adaptou, fez uma rampinha lateral pra ficar na altura do paciente e resolveu.

Pode-se perceber, também, que a capacidade de trabalho de um deficiente físico não é só aceita como real, como pode ser ressaltada. Nestes casos (6 relatos), a deficiência física é vista, por estas pessoas, como um fator positivo e não negativo para o empregador. A deficiência pode ser percebida, também, como algo positivo para o próprio empregado, que se sente mais seguro, pois entende que há uma maior sustentação, não só pela sua capacidade de trabalho, dedicação, concentração e responsabilidade mas, também, por ter uma garantia legislativa que não permite que seja mandado embora. Todos estes fatores são lembrados no relato abaixo: 
Pessoa 3: Eu era o único que trabalhou ali dentro, que aprendeu todos os programas ali dentro e tinha que passar pra todos os departamentos, então eles não iam me mandar embora porque precisavam de mim. Eu acho que a única influência que possa ter é por você ser visto como intocável no serviço. É você ser visto, como impossível de ser mandado embora. Principalmente com as leis que regem, que são fortes no sentido do deficiente né? Então o artigo diz que a empresa tem que ter no mínimo dez por cento de funcionários com alguma deficiência, tanto física, como outros tipos de deficiências... Porque às vezes, a chefia, ela vai se sentir um pouco queimada, a imagem, se caso mandar um deficiente embora. Principalmente se não for ele que tiver dado o cargo pra pessoa.

A forma como a pessoa com lesão medular é percebida dentro do ambiente de trabalho em relação às suas capacidades e habilidades profissionais, também foi uma questão considerada importante, neste contexto, e é apresentada na tabela 23. As implicações que esta deficiência traz para esta pessoa no seu ambiente de trabalho, assim como as repercussões sociais proeminentes e a forma como ela percebe o olhar daqueles que fazem parte do seu dia-dia ocupacional são aspectos levantados nesta análise.

Tabela 23. A percepção social da pessoa com lesão medular em seu ambiente de trabalho, segundo os entrevistados

\begin{tabular}{|c|c|c|}
\hline PERCEPÇÃO & $\mathbf{P}$ & $\mathbf{F}$ \\
\hline naturalmente & $1,3,7,11$ & 04 \\
\hline $\begin{array}{l}\text { com curiosidade ou estranhamento } \\
\text { (devido a falta de informação) }\end{array}$ & $2,3,7,10$ & 04 \\
\hline visão estigmatizante & $6,9,12$ & 03 \\
\hline com irritação & 9 & 01 \\
\hline \multirow[t]{2}{*}{ com admiração } & 11 & 01 \\
\hline & Total & 13 \\
\hline
\end{tabular}

Os entrevistados, neste caso, referem-se a cinco formas distintas em que o deficiente é visto no ambiente de trabalho. Há aqueles que afirmam que são percebidos de forma natural, sem distinções ou qualquer tipo de discriminação ou diferenciação por parte dos colegas de trabalho (4 relatos), há os que acreditam que o deficiente é sempre motivo de uma maior curiosidade, chamando a atenção aos olhares de quem está por perto (4 relatos), há a afirmação de uma visão estigmatizante onde o deficiente é visto como um incapacitado ou impossibilitado de exercer as atividades imprescindíveis ao seu dia-dia (3 relatos), uma 
percepção na qual o deficiente torna-se um empecilho e, portanto, motivo de irritação para seus colegas de trabalho (1 relato) e, por fim, pode ocorrer um sentimento de admiração (1 relato). Vale ressaltar que a visão estigmatizada do deficiente, em seu ambiente de trabalho, foi também destacada na tabela 20 , como um dos principais obstáculos encontrados. É importante, ainda, que uma visão não deve necessariamente excluir a outra, de forma que esta pessoa acometida por uma lesão medular, possa realmente ser percebida em seu ambiente de trabalho de todas estas maneiras, concomitantemente. As falas dos entrevistados mostraram, de forma clara, que a maneira como cada um deles percebe o olhar do outro, está intimamente relacionada com as suas vivências pessoais e profissionais. Algumas de suas percepções podem ser vislumbradas no relato abaixo:

Pessoa 3: No serviço também aconteceu várias vezes até todo mundo, até eu passar o relatório pra todo mundo de como eu tava, todos me perguntavam a mesma coisa, se eu não tinha ficado com nenhuma atrofia, porque que eu tava na cadeira de rodas se minhas pernas não são atrofiadas, então não tava faltando nada, era só levantar e andar. Mas não é só isso, não é uma atrofia na perna que deixa a pessoa na cadeira de rodas, tem muita, uma série de coisas...

A falta de conhecimento sobre as características desta deficiência parece ser um fator significativo na compreensão das reações empreendidas pelos colegas de trabalho, dirigentes ou colegas de estudo, como citada no relato acima. Em outros relatos, a iniciativa indicada por estas pessoas de querer auxiliar de alguma forma, pode ser entendida pelo deficiente físico como algo natural ou como uma manifestação desnecessária, podendo denotar a esta pessoa a idéia de incapacidade. Os relatos seguintes revelam essas visões diferenciadas:

Pessoa 1: Eu acho que é visto como uma pessoa normal, não tem discriminação. Tem lugares que tem ajuda, eles ajudam... mas eu acho que é visto como uma pessoa normal. Ele vai tá reabilitando ali, devem estar no máximo ajudando a pessoa, mas eu acho que ela é vista como uma pessoa normal. 
Pessoa 6: No meu caso, eu digo pra você que, como mesmo as coisas não me faltavam... eu chego no quartel as pessoas querem ajudar, querem ajudar, querem levar a cadeira..eu digo: Só assiste cara... Não quero que ninguém me ajude. Porque eu tenho que partir diretamente de mim, ter a minha liberdade e sabe, nunca, ficar assim: Pô, me ajuda aqui, $R$., pega aquilo pra mim... pega isso pra mim... minha independência, é isso.

Em outros casos, a pessoa com lesão medular pode sentir em seus relacionamentos de trabalho uma segurança que lhe permite estar à vontade para se expor, não exercendo somente um papel profissional, mas também se relacionando socialmente nos momentos de lazer e descontração, como pode ser percebido na fala que se segue:

Pessoa 3: É assim, a nossa equipe de trabalho, tanto dentro como fora do trabalho, continua sendo o mesmo nível de amizade. Então, como sexta-feira passada mesmo, eu fui embora pra casa uma hora da manhã. Nós fomos num churrasco na casa de uma amiga nossa que trabalha com a gente. No outro final de semana retrasado, eu também fui embora pra casa quase uma hora da manhã porque tava na casa do chefe com outros amigos de trabalho também num jantar, então, a gente se reúne e basicamente de quinze em quinze dias a gente ta se reunindo num lugar. Ou na minha casa, ou na casa da minha colega, ou na casa da outra chefe que trabalha com a gente, ou na casa do chefe maior.

É importante perceber, em seus relatos, que estas pessoas não se encontram passivas nesta relação, mas se percebem como seres ativos e responsáveis pela forma como suas vidas se configuram e pelos vínculos profissionais por eles formados. Os relacionamentos desprovidos de estigmas incapacitantes, formados no ambiente profissional, são fundamentais para que ela possa estabelecer uma boa relação com o trabalho exercido. Desta forma, ela pode se sentir estimulada a realizar as suas funções de maneira produtiva. $\mathrm{O}$ aspecto familiar será enfatizado no próximo bloco temático. 


\subsection{Bloco Temático 3: Quanto ao aspecto familiar}

A família representa o primeiro contato social de um indivíduo e o mesmo estende-se ao longo de sua vida, com repercussões mais ou menos visíveis nos seus relacionamentos posteriores (NOVAK, 1996). Pode-se afirmar, então, a importância da família na construção de uma identidade e na forma como os indivíduos se enxergam e se expressam socialmente. No que diz respeito ao deficiente físico e, mais particularmente à pessoa com lesão medular, observa-se que as características das famílias e experiências vivenciadas dentro do contexto familiar são de primordial importância para o seu restabelecimento e reestruturação física, psíquica e social. Pesquisas como as de Araújo (2001) atestam uma visão de família cada vez mais freqüente em nossa realidade, onde os pais e familiares participam ativamente de intervenções reabilitacionais do deficiente, ocupando o papel de colaboradores, ampliando desta forma as possibilidades de atuação e melhores resultados. A percepção que a pessoa com lesão medular possui sobre as suas relações familiares, as repercussões desta lesão na dinâmica familiar, assim como a maneira com que esta família encara a deficiência e o impacto da mesma no contexto familiar, é um dos tópicos abordados junto aos participantes desta pesquisa. A participação familiar na reabilitação destas pessoas e, também, os efeitos e a importância da presença destes familiares em todo o processo reabilitacional empreendido pelos portadores de lesão medular, são outras questões abordadas. A diferença na forma como cada familiar lida com a deficiência e até como uma mesma família encara a deficiência, em épocas diversas, pode estabelecer reações que vão desde a sua ruptura e desorganização até uma maior união e fortalecimento das interações entre seus membros (KOVACS, M. 1997). O fato desta pesquisa estar tratando de uma lesão medular, torna este acontecimento algo singular, já que ele nunca é esperado. Neste sentido, torna-se importante ouvir as pessoas com lesão medular e seus familiares.

As tabelas 24 e 25 ilustram as reações iniciais apresentadas por estas famílias ao se depararem com o advento de uma lesão medular, na concepção dos entrevistados (tabela 24) e de seus familiares (tabela 25). 
Tabela 24. Reações iniciais da família diante da deficiência, de acordo com os entrevistados.

\begin{tabular}{c|ccc}
\hline \multicolumn{2}{c}{ PRIMEIRA REAÇÃO FAMILIAR } & $\mathbf{P}$ & $\mathbf{F}$ \\
\hline \hline & tristeza & $1,2,4,12$ & 04 \\
& mágoa & 4,2 & 02 \\
& comoção & 5,8 & 02 \\
& culpa & 2 & 01 \\
& medo & 6 & 01 \\
& preocupação & 12 & 01 \\
& não demonstrou & 9 & 01 \\
& choque & Subtotal & 12 \\
\hline \hline & & $1,4,5,6,11$ & 05 \\
& Comportamento de compensação - & Subtotal & 05 \\
\hline \hline & busca de apoio entre si (união) & 1,7 & 02 \\
& descrença & Subtotal & 02 \\
\hline \hline & indiferença & 11 & 01 \\
& & Subtotal & 01 \\
\hline \hline
\end{tabular}

Tabela 25. Reações iniciais da família diante da deficiência, de acordo com os familiares.

\begin{tabular}{|c|c|c|c|}
\hline \multicolumn{2}{|c|}{$\begin{array}{c}\text { PRIMEIRA REAÇÃO } \\
\text { FAMILIAR }\end{array}$} & \multirow{2}{*}{$\begin{array}{c}\text { FAMILIAR } \\
1,2,3\end{array}$} & \multirow{2}{*}{$\begin{array}{c}\mathbf{F} \\
03\end{array}$} \\
\hline 象 & comoção & & \\
\hline 羔 & tristeza & 3 & 01 \\
\hline & & Subtotal & 04 \\
\hline \multirow{2}{*}{\multicolumn{2}{|c|}{ desestruturação emocional }} & 3,7 & 02 \\
\hline & & Subtotal & 02 \\
\hline \multirow{2}{*}{\multicolumn{2}{|c|}{ choque }} & 3 & 01 \\
\hline & & Subtotal & 01 \\
\hline \multirow{2}{*}{ 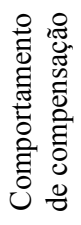 } & \multirow[t]{2}{*}{ compulsão alimentar } & 5 & 01 \\
\hline & & Subtotal & 01 \\
\hline & & Total & 08 \\
\hline
\end{tabular}

De acordo com suas falas, a lesão medular é repercutida na família como algo inesperado, gerando uma complexidade de sentimentos marcados pela dor de saberem que este familiar, acometido pela lesão, não será mais como antes. Sentimentos como de tristeza e comoção, respectivamente, além do choque inicial, parecem estar presentes com maior freqüência neste primeiro momento. Tanto os entrevistados, quanto seus familiares, ressaltam a 
existência destes sentimentos como reações imediatas destas famílias ao perceberem que um de seus membros se encontra na condição de lesado medular ou mesmo pela fatalidade que o levou a isto, como pode ser observado nos depoimentos seguintes:

Pessoa 5: E de repente ela vê um pai, que tava sempre disputando tudo, que ela ia lá ver jogar bola, que ela ia ver disputando campeonato e ver ele numa cadeira de rodas, ela sentiu um baque muito grande.

Familiar 2: porque quando ela [Pessoa 2] sofreu o acidente ela era uma criança, ela tinha nove anos, ela era uma criança. Então pra mim foi muito dificil, pro meu marido é difícil até hoje, vou falar pra você.

Na percepção dos entrevistados, há a presença de um comportamento de "compensação", expresso pela busca de apoio entre si e uma maior união familiar. Do ponto de vista da família, houve uma resposta indicando a "compulsão alimentar", como uma forma de compensação. Com um e dois relatos respectivamente, observou-se a desestruturação familiar. A percepção que estas pessoas possuem sobre seus familiares, assim como a percepção que os próprios familiares possuem sobre seus comportamentos, sentimentos e expectativas encontram-se apresentadas, respectivamente, nas tabelas 26 e 27 , nas quais os entrevistados e seus familiares, revelam alguns comportamentos, sentimentos e expectativas como famílias de pessoas com lesão medular e informantes desta pesquisa. 
Tabela 26. Percepção dos entrevistados sobre os comportamentos, sentimentos e expectativas de seus familiares.

\begin{tabular}{|c|c|c|c|c|}
\hline \multicolumn{2}{|c|}{ PERCEPÇÃO } & CONTEÚUD & $\mathbf{P}$ & $\mathbf{F}$ \\
\hline \multirow{15}{*}{ 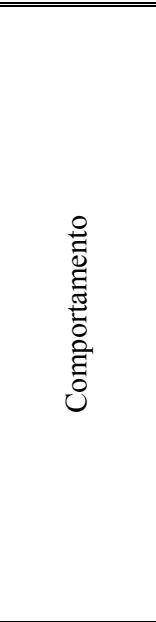 } & \multirow{9}{*}{ 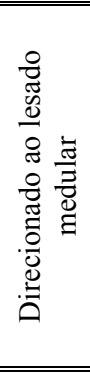 } & incentivam uma maior autonomia e independência & $2,3,6,9$ & 04 \\
\hline & & ajudam como podem & $4,7,8$ & 03 \\
\hline & & estão sempre apoiando & $7,9,11$ & 03 \\
\hline & & adaptam os espaços físicos (adaptação arquitetônica) & 2,3 & 02 \\
\hline & & não compreendem suas necessidades & 8,9 & 02 \\
\hline & & estão sempre auxiliando e protegendo & 3 & 01 \\
\hline & & tentam controlar e dominar & 7 & 01 \\
\hline & & não se relaciona & 10 & 01 \\
\hline & & & Subtotal & 17 \\
\hline & \multirow{5}{*}{ 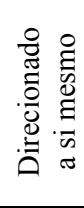 } & procuram se adaptar à situação & $1,3,4,5,6$ & 05 \\
\hline & & compartilham os objetivos do deficiente & 6 & 01 \\
\hline & & compartilham as realizações do deficiente & 4 & 01 \\
\hline & & assumem todas as funções familiares & 5 & 01 \\
\hline & & & Subtotal & 08 \\
\hline & & & Subtotal & 25 \\
\hline \multirow{7}{*}{ 异 } & & frustração & 4 & 01 \\
\hline & & não há sofrimento & 6 & 01 \\
\hline & & não demonstra sentimento & 5 & 01 \\
\hline & & tristeza & 12 & 01 \\
\hline & & admiração ao deficiente & 11 & 01 \\
\hline & & entusiasmo com melhorias alcançadas & 9 & 01 \\
\hline & & & Subtotal & 06 \\
\hline \multirow{3}{*}{ Expectativa } & & recuperação da locomoção do familiar deficiente & 1,9 & 02 \\
\hline & & não apresenta expectativa de melhorias & 9 & 01 \\
\hline & & & Subtotal & 03 \\
\hline & & & Total & 34 \\
\hline
\end{tabular}

Os comportamentos ora se direcionam a si mesmos, ora aos familiares com lesão medular. $\mathrm{Na}$ tabela 26, os entrevistados apontam, principalmente, para o incentivo dado pelas suas famílias, com o intuito de que estas pessoas adquiram uma maior autonomia e independência, além de uma tentativa, por parte de seus familiares, em adaptar-se à situação em que estão se deparando no momento. Com relação à tabela 27 , observou-se, ainda, formas de enfrentamento baseadas no suporte social, na aceitação passiva da condição vivida pelo deficiente e no suporte espiritual. No comportamento direcionado à pessoa com lesão medular, foi possível observar não somente o incentivo à independência, mas também o incentivo à realização de tratamentos reabilitacionais, convivendo com o estabelecimento de uma relação de interdependência. 
Tabela 27. Percepção de familiares sobre seus comportamentos, sentimentos e expectativas no que concerne à pessoa com lesão medular.

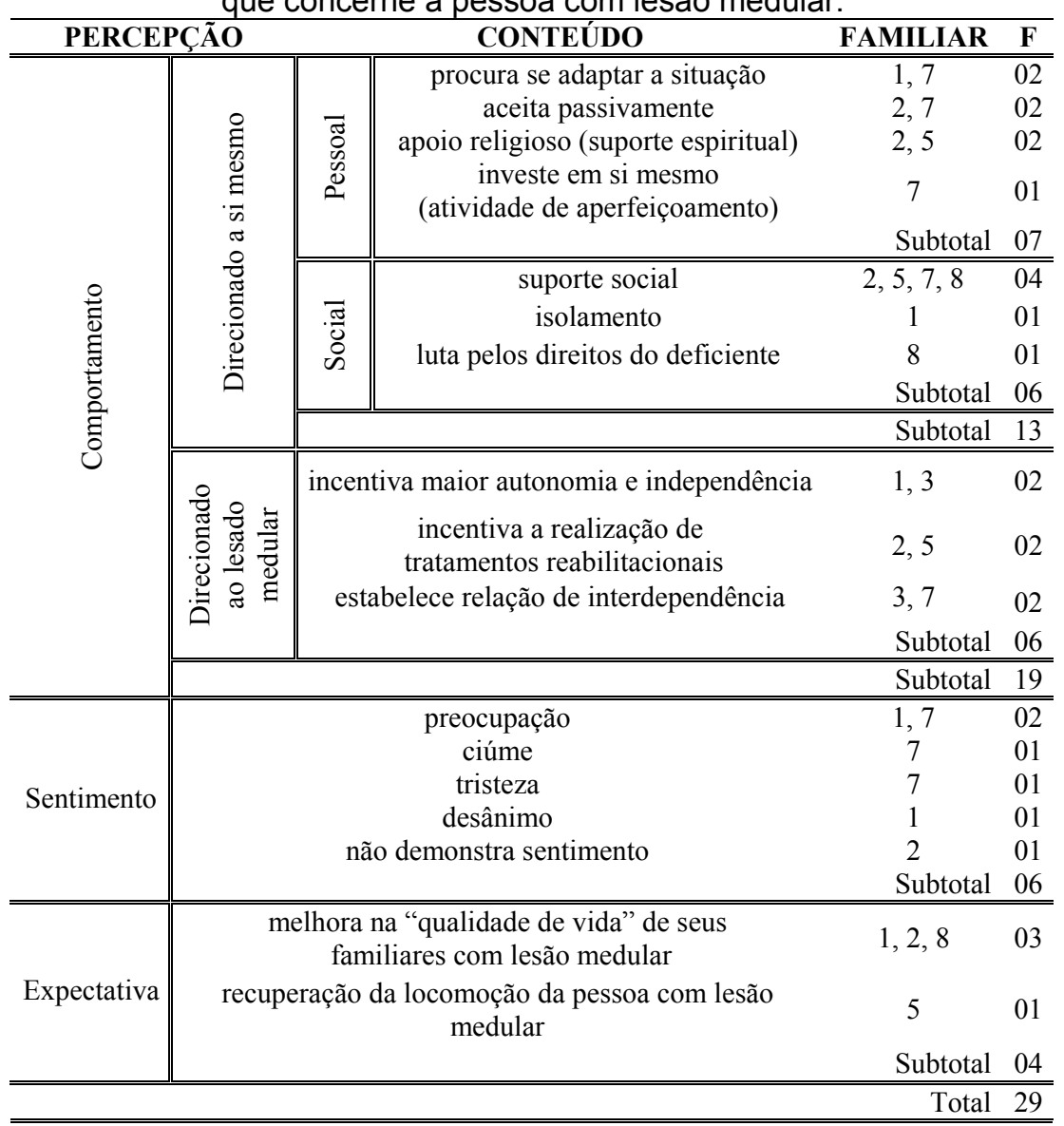

Em dois dos relatos, os entrevistados discorrem sobre a expectativa de seus familiares na recuperação de suas funções motoras responsáveis pela locomoção, enquanto que seus familiares relatam com maior freqüência, uma expectativa baseada em melhorias na "qualidade de vida" de seus parentes portadores de lesão medular. Tais expectativas podem ser evidenciadas nos seguintes depoimentos:

Pessoa 6: Eles acreditam também que eu vou andar. Isso é fé.

Familiar 1: Eu falo pra ele: filho nada se acabou, se adiou apenas. Não é verdade? Apenas se adiou os seus projetos de vida. 
Em relação ao comportamento direcionado à pessoa com lesão medular, pode-se constatar que a independência destas pessoas é considerada algo importante para estas famílias, embora admitam, muitas vezes, as dificuldades para que a mesma seja atingida. Em alguns de seus relatos, é ressaltado o valor dado pelos familiares a um comportamento mais independente por parte das pessoas com lesão medular:

Familiar 1: Olha não deve ser assim! Agora eu estou tirando o costume do... [Pessoa 1] de: mãe põe a meia, por causa daquela meiona, ai mãe eu tô com uma dor nas costas... não posso. Ai eu vou lá e ponho. Mas é se eu preciso me internar, como é que ele vai se virar? Os sapatos, o terapeuta dele: você põe os sapatos. Ele põe, faz até isso aqui. Amarra. Ele faz a transferência dele, ele toma banho, faz a barba, tudo sozinho.

Considerando o contexto apresentado, Faro (2001) identifica a relação do cuidador e do deficiente indo desde aquele que possui comportamentos completamente passivos, caracterizados por prover o deficiente de todas as suas necessidades sem questionar sobre quais seriam suas condições reais de dependência, até àquele cuidador que observa atentamente se o mesmo tem possibilidades de exercer ou não sozinho uma certa atividade, como é apontado no depoimento anterior (F1).

A reabilitação possui uma representatividade para estes familiares que está relacionada com o esforço das pessoas acometidas pela lesão para se cuidarem e se recuperarem no sentido global de sua patologia. Por este motivo, estes familiares acabam por incentivar a pessoa com lesão medular em todo o seu processo reabilitacional. Este comportamento encontra-se explicitado no relato abaixo:

Familiar 2: Eu tento enfiar na cabeça dela e falar pra ela, porque ela pensa e eu penso assim muito no lado do dia de amanhã porque a medicina tá trabalhando, eles tão pesquisando, uma hora de chegar um resultado pra não tá atrofiada, então eu falei pra ela: mesmo que não tá fazendo a fisioterapia aqui, mas tá estimulando o nervo, de alguma forma, você não tá sentindo, não tá sentindo, mas... tá fazendo alguma coisa, tá ajudando 
né? Então não tá aquela coisa morta, parada né? O resto da vida. Então ela vem justamente por causa disso aí, pra pensar na melhoria do dia de amanhã.

É importante perceber que a ocorrência de uma lesão medular, pode adquirir significados diferenciados para cada família e para cada familiar. Em alguns casos, ela pode representar uma mudança importante tanto para a família, como para a própria pessoa com lesão medular. A Pessoa 6 indica, em seu depoimento, sua percepção de como seus familiares entendem a sua patologia:

Pessoa 6: Porque aconteceu isso, meus pais também são evangélicos, eles sabem que aconteceu isso aqui pra haver mudanças. Mas a certeza que eu tenho e que eles com certeza tem também é que precisou, Deus parar eu aqui.

Muitas vezes, ao passar por situações inesperadas, eles chegam a se surpreender com sua força e capacidade de superação. Os familiares percebem que conseguiram sobreviver e reagir de alguma forma aos períodos mais complicados e passam a acreditar na sua capacidade de superar seus problemas, como é revelado na fala abaixo:

Familiar 5: Era super ativo. De repente eu vi meu marido em cima duma cama, eu não sei onde eu consegui tanta força pra tá refletindo pra ele.

Faro (1999), acredita que haja um melhor ajustamento familiar no que se refere às dificuldades existentes nos aspectos físicos e/ou fisiológicos, já que o aprendizado dos cuidados físicos ocorrem mais rapidamente do que os ajustamentos emocionais e financeiros. Mendes (1998), por sua vez, enfatiza que a familiaridade com os aspectos relacionados a uma deficiência debilitante dar-se-á a partir de um processo de elaboração e ressignificação, tanto por parte da pessoa com lesão medular, como também no que diz respeito a sua família.

A caracterização dos relacionamentos familiares realizadas pelos entrevistados, encontra-se evidenciada na tabela 28 . 
Tabela 28. Caracterização do relacionamento dos entrevistados com seus familiares.

\begin{tabular}{|c|c|c|c|}
\hline RELACIONAMENTO & CONTEÚDO & $\mathbf{P}$ & $\mathbf{F}$ \\
\hline \multirow{5}{*}{ Como se relaciona } & $\begin{array}{l}\text { descreve importância de sua participação no } \\
\text { contexto familiar }\end{array}$ & $5,7,11$ & 03 \\
\hline & “vive bem" (P8) & $8,9,11$ & 03 \\
\hline & normalmente (com altos e baixos) & 4,12 & 02 \\
\hline & não há relacionamento & 10 & 01 \\
\hline & & Subtotal & 09 \\
\hline \multirow{4}{*}{ Com quem se relaciona } & $\begin{array}{l}\text { descreve presença de familiares mais distantes ou } \\
\text { separados (família estendida) }\end{array}$ & 1,11 & 02 \\
\hline & família nuclear & 2,9 & 02 \\
\hline & família extensa ou psicológica & 7 & 01 \\
\hline & & Subtotal & 05 \\
\hline & & Total & 14 \\
\hline
\end{tabular}

Como pode ser percebido na tabela 28 , os entrevistados ao serem questionados sobre suas relações familiares, denunciaram dois aspectos diversificados de tais relacionamentos, caracterizados pela forma como suas famílias são constituídas e pela forma como eles se relacionam com estas famílias. Dois relatos se referem ao primeiro aspecto e dois se reportam ao segundo. Abrangeram, no primeiro aspecto, duas famílias estendidas, duas famílias nucleares e uma família extensa ou psicológica. Quando relataram a maneira como se relacionam, eles chamam a atenção para a importância de sua própria participação e consideram possuir um relacionamento estável, com ajuda mútua, como nos depoimentos que se seguem:

Pessoa 1: De bom pra ótimo né? Não tenho pra te falar alguém que eu tenha alguma queixa, não tenho. Eu tenho uma tia que é separada e ele continua meu tio. Ele podia nem aparecer na minha casa, mas vira e mexe ele ta passando lá em casa.

Pessoa 11: Porque ela [esposa] conhece quando eu tô de baixo astral assim, ela sabe. Então ela começa a falar: não a gente vai vencer, você tem que perseverar, tem que lutar, sem deixar isso acontecer. Só que da mesma forma acontece com ela, tem dia que ela tá derrubada aí, que eu tô lá em cima também.

Pessoa 5: eu tenho certeza que eu ajudei bastante, ajudo bastante as minhas filhas, a minha esposa. 
Apenas um dos entrevistados apontou a inexistência de relacionamento familiar, como pode ser destacado em seu depoimento:

Pessoa 10: Com a minha irmã eu não converso, eu moro com ela mas não converso, e os outros não é capaz de ligar pra mim aí eu também não ligo.

As mudanças nestas relações, a partir do advento da lesão medular, também, são aspectos considerados em suas falas, como é perceptível nos seguintes relatos:

Pessoa 3: Eu acho que se mudou com a deficiência foi um por cento. Mas eu não consigo ver esse um por cento onde mudou, porque eu sempre fui muito bem quisto. A única coisa que eu tenho um privileginho a mais é na casa da minha tia em São Bernardo quando eu vou, pelas condições, isso é pelas condições...então eles me dão o melhor lugar pra dormir. Não tem aquela coisa deles falarem: Ah, coitadinho dele, a gente maltratou ele no começo, então vamos começar a tratar bem agora porque ele sofreu um acidente. Isso não tem. De forma alguma!

Pessoa 6: Perfeitamente. Melhorou o relacionamento. Hoje eu sei quem é meu pai e minha mãe. Minha familia! Valorizo!

A percepção dos entrevistados sobre a participação de seus familiares na sua reabilitação é apresentada na tabela 29.

Tabela 29. Percepção dos entrevistados sobre a participação dos familiares no seu processo reabilitacional.

\begin{tabular}{|c|c|c|}
\hline PARTICIPAÇÃO & $\mathbf{P}$ & $\mathbf{F}$ \\
\hline acompanham no tratamento & $1,2,3,4,5,7,11$ & 07 \\
\hline interesse pelos resultados obtidos & $3,4,6,7$ & 04 \\
\hline ajudam nas atividades diárias & 6,8 & 02 \\
\hline $\begin{array}{c}\text { buscam tratamentos alternativos } \\
\text { e soluções adaptativas }\end{array}$ & 2,6 & 02 \\
\hline demonstram companheirismo/preocupação & 6 & 01 \\
\hline se disponibilizam para transportá-lo & 10 & 01 \\
\hline ajudam no tratamento domiciliar & 8 & 01 \\
\hline \multirow[t]{2}{*}{ não participam } & 12 & 01 \\
\hline & Total & 17 \\
\hline
\end{tabular}


Como pode ser percebido na tabela 29 , as famílias dos entrevistados participam ativamente no seu processo reabilitacional, seja levando-os e acompanhando-os durante os tratamentos (7 relatos), mostrando interesse pelos resultados obtidos (4 relatos), ajudando nas atividades diárias ( 2 relatos) procurando alternativas, tratamentos novos e etc (2 relatos) e auxiliando no tratamento domiciliar (1 relato), ou mesmo pelo simples fato de "estar junto", demonstrar preocupação (1 relato). Nos depoimentos abaixo, os entrevistados relatam algumas destas maneiras de participação familiar, ressaltando-se as que foram mais enfocadas em suas falas:

Pessoa 2: Eu tinha uma tia, tirando o meu pai e minha mãe, eu tinha uma tia que me levava pra fisioterapia, teve alguns tios meus que falavam: Ah, ela tem que fazer massagem e ficavam inventando coisa pra que talvez eu pudesse ter alguma melhora.

Pessoa 4: Participam. Eu falo né, o que tá acontecendo, o que tá deixando de acontecer... Seriam meus pais, a minha esposa, os irmãos, os irmãos dela também. Mais a minha esposa né? Tem o meu sogro que ele me ajuda, ele me leva pra fisioterapia e aqui pra Unicamp.

Pessoa 3: Só a minha mãe e o meu pai mesmo. Eu acho que eles fazem tudo que eles podem e o que não podem também. Vou dizer que eles dão cento e dez por cento deles. Não teria como falar, não o meu pai não me ajuda, não. Ele tem o serviço dele obviamente, ele tem os afazeres dele, minha mãe também, mas o que for preciso, que nem hoje era um dia que meu pai podia ter arranjado uma outra pessoa pra me trazer aqui, mas ele deixa o serviço dele pra vir me trazer aqui. Mesmo pra ta acompanhando, pra ta vendo, pra ta olhando pra ver como é que ta a progressão, aquela coisa toda. Então eu acho que eles dão cento e dez por cento deles.

No relato acima, é possível constatar a dedicação apresentada por algumas famílias em relação à pessoa com lesão medular, chegando a abdicar, muitas vezes, dos seus afazeres diários para atender as necessidades do seu familiar deficiente. A participação destas famílias, acompanhando a pessoa com lesão medular em todo o seu processo reabilitacional 
(tabela 29), reafirma tal constatação. Estudos realizados por Matsukura (2001), mostraram que mães de pessoas com deficiências, possuem pouco tempo para se dedicarem as suas relações e atividades sociais, por estarem envolvidas com os problemas de seus filhos. Portanto, esta situação dificulta a formação de uma rede de suporte social. Outros estudos, como o de Vital (1996) reafirmam a dificuldade entre mães e pais de crianças deficientes, para cuidarem de si mesmos e de suas vidas pessoais, devido ao tempo dedicado aos filhos deficientes.

Vale ressaltar que em apenas um dos relatos a família não participa do processo reabilitacional da pessoa com lesão medular.

A tabela 30, refere-se à percepção dos entrevistados sobre a contribuição de seus familiares para uma melhor reabilitação.

Tabela 30. Percepção dos entrevistados sobre a contribuição dos familiares na sua reabilitação.

\begin{tabular}{c||ccc}
\hline CONTRIBUIÇÃO & CONTEÚDO & P & F \\
\hline \hline \multirow{4}{*}{ Pessoal } & $\begin{array}{c}\text { suporte afetivo (apoio) } \\
\text { não influenciam } \\
\text { (não atrapalham) } \\
\text { incentivo à } \\
\text { independência }\end{array}$ & $2,4,5,7,9,11$ & 06 \\
Física & $\begin{array}{c}\text { prevenção de } \\
\text { complicações }\end{array}$ & 2 & 01 \\
& $\begin{array}{c}\text { manutenção de estrutura } \\
\text { corporal }\end{array}$ & 4 & 01 \\
\hline \hline \multirow{2}{*}{ De uma forma geral } & Subtotal & 08 \\
\hline \hline
\end{tabular}

A ajuda familiar em relação à reabilitação é um ponto comum entre os entrevistados. Eles acreditam, de uma forma geral, que a família possui um papel essencial no seu processo reabilitacional contribuindo, principalmente, no que condiz ao aspecto pessoal. As contribuições afetivas são bastante significativas para estas pessoas e podem ser ilustradas nos seguintes relatos:

Pessoa 4: Eu acho legal. Eu acho que todo deficiente físico tem que ter um apoio. Porque se ele não tiver um apoio dentro de casa ele vai parar, ele não vai continuar. 
Pessoa 5: Eu digo que não tem nota. Não tem como você fazer uma avaliação. Eu acho que ela é tudo, se ela não tivesse aqui eu não teria força pra continuar aqui, fazendo o tratamento, tentando pelo menos né. E ela é o esteio né. Quando ela fica ausente por algumas horas a gente já sente falta né, então é difícil... e ela é tudo! A contribuição dela é total, ela faz parte de tudo. Sem ela não teria essa força toda pra tá aqui não.

Uma outra contribuição importante da família, embora aparecendo com menor freqüência, diz respeito ao aspecto físico, ou seja, aos cuidados exercidos por estes familiares para evitar o aparecimento de complicações que poderiam trazer dificuldades em uma possível reabilitação. Estas complicações se referem às condições físicas das pessoas com lesão medular e são caracterizadas no depoimento que se segue:

Pessoa 4: Sim. Tem contribuido, eu graças a Deus, em relação a outros deficientes eu não perdi massa muscular, tô bem. Não tive nenhum problema sério como outros deficientes tem, não tive escara...

O sentimento de gratidão pelas famílias que possuem, é muito eminente nos depoimentos dos entrevistados. A família, para eles, tem um valor inestimável e ainda de acordo com seus relatos, deve ser recompensada de alguma forma, devido a todo o seu esforço e sacrifício. $\mathrm{O}$ valor afetivo dos cuidados familiares também é reconhecido e reafirmado em seus relatos, como se pode perceber através das seguintes falas:

Pessoa 2: Em relação aos meus pais eu me sinto premiada. Deus me deu a oportunidade de ter uma família tão abençoada. O que eles fazem eu nem sei como vou um dia agradecer tudo que eles fizeram por mim. Isso é muito importante, eu amo eles!

Pessoa 3: É por eles que eu estou aqui, é por eles que eu estou batalhando e é por eles que eu quero vencer também. Então eu não sei quanto tempo mais vai levar, se eu vou conseguir esse ano, se vai ter mais um ano pela frente... não importa o tempo que demore 
pra eu me reabilitar e comece a dar os meus passos sozinho, mas o importante é que eu consiga é é por eles que eu estou fazendo.

A análise do relato de alguns familiares dos entrevistados desta pesquisa é de suma importância para o entendimento do contexto familiar em que estas pessoas se inserem. Os depoimentos coletados a partir destes familiares trazem, para a análise, questões, tais como, os seus conhecimentos sobre a lesão, anteriores ao advento desta patologia em um de seus membros, a forma como percebem a deficiência de seu membro familiar (aspectos relacionados à lesão medular citados por estes familiares) e, principalmente, a visão que os mesmos possuem deste indivíduo. Como esta família compreende as formas de enfrentamento utilizadas por estas pessoas, de uma forma geral, é apontada nas falas destes familiares, de maneira a se tornar visível não somente o que a pessoa com lesão medular traz como sua verdade, mas também, o que tem sido relevante e diferenciador nas vidas destes familiares junto à pessoa com lesão medular. A tabela 31, diz respeito às informações adquiridas pelas famílias anteriormente à ocorrência da lesão medular em um de seus familiares.

Tabela 31.Conhecimentos anteriores dos familiares sobre a lesão medular.

\begin{tabular}{ccc}
\hline CONHECIMENTO & FAMILIAR & F \\
\hline \hline não sabia dos efeitos & 2,5 & 02 \\
não sabia o que causava & 5 & 01 \\
desconhecimento sobre as providências que deveriam & 2 & 02 \\
ser tomadas & Total & 05 \\
\hline \hline
\end{tabular}

Como pode ser observado na tabela 31 , a mesma falta de conhecimento inicial, sobre os efeitos advindos da lesão medular constatada nos relatos dos portadores de lesão medular, encontra-se presente, também, nos relatos de seus familiares.

Nestes casos, a falta de informação sobre as conseqüências de uma lesão como esta é um aspecto desnorteador, já que muitas pessoas não têm acesso e, muitas vezes, nunca tinham ouvido falar sobre os efeitos de uma lesão medular, muito menos sobre as providências que a família deveria tomar nestes casos. Tomás e Llaras (1997) afirmam que o desconhecimento sobre os cuidados necessários e a falta de um suporte profissional 
consistente são causadores de angústia para estes familiares ao se depararem com situações inesperadas. Gonzalez (2000), em estudos realizados sobre a alta hospitalar do paciente com lesão medular, constatou a ausência do acompanhamento, informação e treinamento da família na situação de pós-alta, ressaltando a importância deste aspecto, visto a complexidade que envolve o quadro clínico estabelecido por uma lesão medular. Os relatos que se seguem confirmam estes fatos:

Familiar 5: e eu, e ela também por mais que o filho dela mais velho, ela pensou nossa o que tá acontecendo? O que tá acontecendo. Não pensou que fosse uma coisa tão grave assim, no início eu não pensei nisso.

Familiar 2: Aí quando ela sofreu o acidente foi... quando a médica me chamou e disse pra nós, chegou aos nossos ouvidos que ela não ia mais fazer xixi, que ela não ia andar mais, eu nem sabia, imagina! E pra dar alta pra ela precisava encontrar um hospital, UNICAMP... Eu não sabia.

Faro (1999), em sua pesquisa sobre a família e o cuidador da pessoa com lesão medular, constatou que estas famílias, ao se depararem com o advento de uma lesão medular por um familiar, acabam encontrando informações difusas e desencontradas entre os profissionais da área sobre o quadro instalado, assim como, em relação às situações que terão que enfrentar. Ghirardi (1999) entende que, em muitos casos, profissionais da área de saúde podem transmitir informações diagnósticas e prognósticas que se encontrem pautadas em suas próprias concepções e estereótipos relacionados com esta ou aquela deficiência em particular. Estes familiares atentam para situações em que os profissionais da área da saúde acabam passando uma visão de descrédito em relação a alguma recuperação, de maneira a incentivar estas famílias a exercer um estilo de enfrentamento baseado na passividade e no conformismo:

Familiar 2: O pessoal daqui... quando eu cheguei no médico e contei tudo isso ele falou... você vai se acostumando. 
A tabela 32 enfoca os efeitos relacionados à lesão medular que foram citados pelos familiares informantes desta pesquisa.

Tabela 32. Efeitos relacionados à lesão medular mencionados pelos familiares.

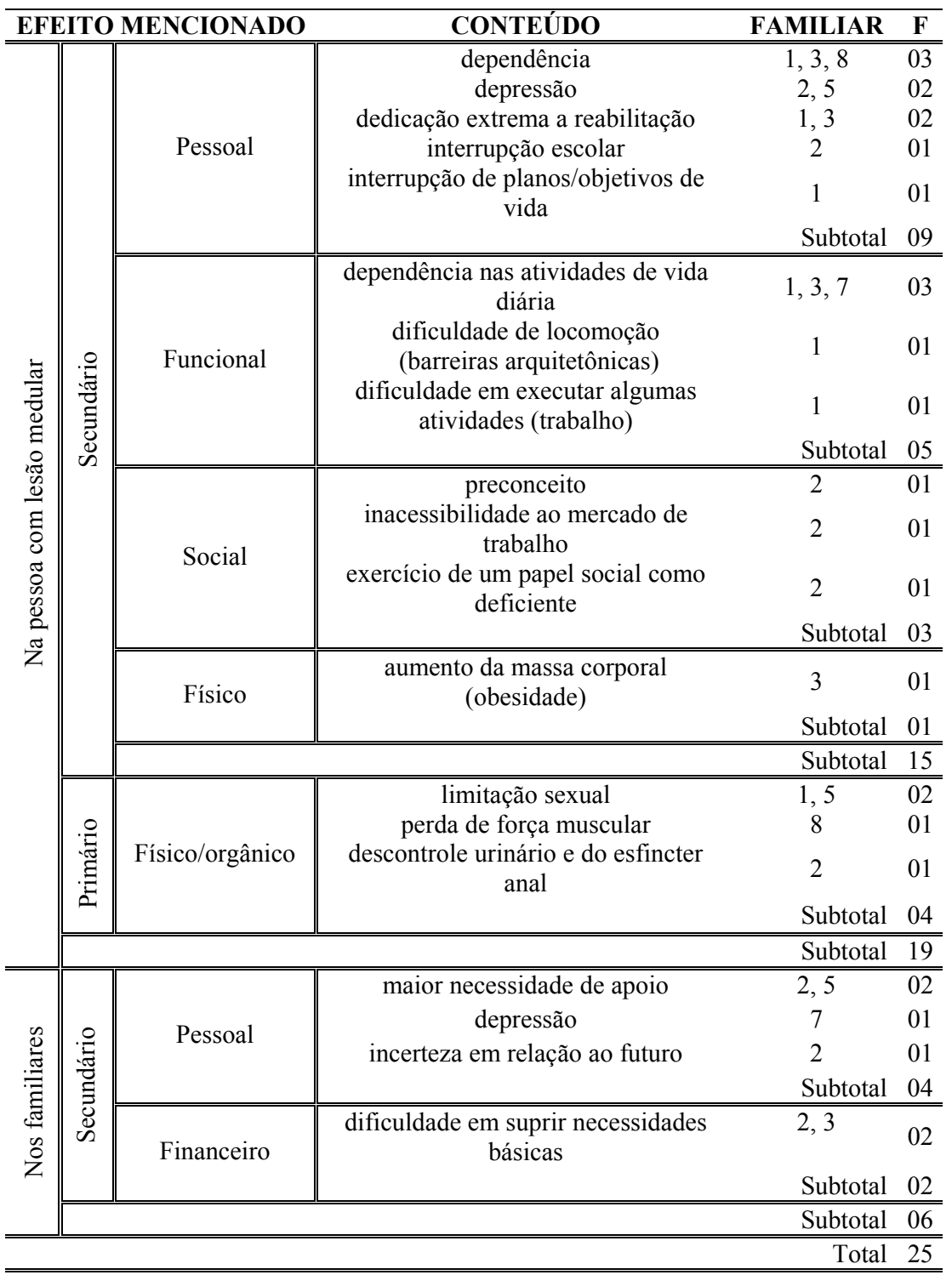

A partir dos relatos dos familiares, contemplados na tabela 32, faz-se importante destacar que a lesão medular trouxe para estas pessoas e suas famílias inúmeras mudanças, que, de acordo com seus familiares, interferiram em sua rotina de vida de formas diferenciadas. Estas mudanças encontram-se relacionadas, principalmente, com os efeitos secundários da lesão e, especificamente, no que se refere à vida pessoal das pessoas acometidas por esta 
patologia. Os familiares ressaltaram que as maiores complicações referentes à lesão medular vão além da dificuldade de se locomover, de se movimentar ou, ainda, de exercer suas funções fisiológicas, como as relacionadas à sexualidade e eliminação de urina e fezes. Existe uma preocupação destes familiares em relação à independência do portador de lesão medular, mais especificamente, no que diz respeito ao desenvolvimento de uma vida social, pessoal e profissional por esta pessoa. Observou-se que a ocorrência de uma maior dependência, foi um dos principais aspectos apontados pelas pessoas com lesão medular, quando questionadas sobre os efeitos desta deficiência em suas vidas (tabela 10). Nos relatos abaixo, pode-se percebê-la com maior nitidez:

Familiar 1: Eu acho que nossos filhos têm que viver a vida deles. Eu já dei o que tinha que dar nessa vida viu? Eu não tenho que dar mais nada não.

Familiar 3 [pai]: O meu intento era viver minha vida eu falei pra ele, agora que ele viva dele, o que eu já tive que fazer eu já fiz.

A dependência na execução das atividades de vida diária, também é apontada por estas famílias e aparece em algumas de suas falas, como no depoimento abaixo:

Familiar 7: Ela fica: mãe pega aquilo, mãe pega aquilo outro, tem hora que ela fica assim, aí a minha cabeça roda.

A necessidade de apoio encontra-se eminente em suas falas e pode ser averiguada no seguinte relato:

Familiar 5: Porque se não tiver uma pessoa de pensamento positivo do seu lado, que possa te dar uma força...

Os familiares entendem a importância do processo reabilitacional e percebem o tempo gasto pelas pessoas com lesão medular, em seu tratamento, como uma forma de enfrentar a sua realidade. Acreditam que o mesmo se constitui em um investimento deste sujeito em si 
mesmo. Em alguns casos, entretanto, as famílias acabam por revelar a preocupação que possuem, de que seus membros familiares com lesão medular estejam abdicando de suas vidas profissionais, sociais, e etc, para estarem se dedicando à reabilitação. Esta preocupação pode ser observada no seguinte relato:

Familiar 1: Mas é que nem diz o médico: a sua vida não é em torno disso só. Mas ele faz. Ele não quer ir pra oficina.

Os familiares também apontam para a ocorrência de depressão entre as pessoas com lesão medular. No entanto, eles percebem a sua função de suporte junto aos seus membros com lesão medular e entendem a importância de estarem compreendendo suas reações em relação à lesão, assim como os seus comportamentos de uma forma geral. Fica visível, em seus relatos, a preocupação destes familiares em incentivar e apoiar, sempre que necessário. Tudo isto pode ser claramente notado no seguinte depoimento:

Familiar 5: Eu coloquei na minha cabeça o seguinte: Eu não vou brigar, com o meu marido, porque às vezes ele anda em depressão e ele acha que realmente não vai andar mais. ...eu não acredito nisso... no pouco que eu leio, eu to me agarrando também. E a gente não pode passar pra eles que a ciência tem limite...

$\mathrm{Na}$ tabela 33, são apresentadas as formas de enfrentamento utilizadas pelas pessoas com lesão medular, de acordo com a percepção de seus familiares.

Tabela 33. Percepção dos familiares sobre as formas de enfrentamento utilizadas pelos entrevistados.

\begin{tabular}{|c|c|c|c|}
\hline FORMA DE & RENTAMENTO & FAMILIAR & $\mathbf{F}$ \\
\hline & social & $1,2,3,7$ & 04 \\
\hline Sunorte & profissional & 2,5 & 02 \\
\hline suporit & familiar & 2,3 & 02 \\
\hline & & Subtotal & 08 \\
\hline avali & passiva & 1,5 & 02 \\
\hline & & Subtotal & 02 \\
\hline & ulação & 2 & 01 \\
\hline & & Subtotal & 01 \\
\hline investimento & vida profissional & 2 & 01 \\
\hline em si mesmo & & Subtotal & 01 \\
\hline
\end{tabular}


A forma como as pessoas com lesão medular lidam com a sua lesão é um dos aspectos citados nos relatos de seus familiares. É visível em suas falas a existência de uma tendência, na maior parte dos depoimentos, a reagir de forma positiva. Pode-se demarcar um estilo de enfrentamento caracterizado pela utilização de suportes sociais (4 relatos), profissionais (2 relatos) e familiares (2 relatos), por uma reformulação de conceitos e valores (1 relato), investimento em si mesmo ( 1 relato), totalizando 10 respostas. $\mathrm{O}$ enfrentamento baseado na avaliação passiva aparece em dois dos depoimentos. Relacionando tais resultados com as falas apresentadas pelos entrevistados, observou-se algumas divergências quanto as formas de enfrentamento utilizadas por estas pessoas, já que as mesmas se referem na sua maior parte, ao suporte profissional, vindo logo em seguida o espiritual e, só depois elas apontam para a utilização de um suporte social e familiar, além dos investimentos em si mesmos, apoio no exemplo de outros e busca de informações (tabela 8). Na tabela 8, a avaliação passiva encontra-se presente em apenas um dos relatos, o que mostra uma percepção diferenciada no que concerne as pessoas com lesão medular sobre si mesmas e de seus familiares. Vale ressaltar entretanto a inclusão, nas duas tabelas, dos suportes profissionais, sociais e familiares, com uma representatividade significativa.

A utilização de um suporte social e também profissional, ou seja, a crença na possibilidade de uma recuperação baseada em tratamentos reabilitacionais, pôde ser observada por suas famílias e encontra-se exemplificado nos depoimentos abaixo:

Familiar 7: E ela [P7] que fica pra baixo e pra cima, com esse carro... ela não para em casa não! Ela tá sentada aí.. ha, vou sair... Ela fala assim..a mãe, vou ficar lá... na amiga dela que tem a loja...

Familiar 2: Ela não é uma pessoa assim. Ela fala assim, se amanhã houver algum tratamento, lógico, se ela vier andar assim...

Um aspecto importante sobre a pessoa com lesão medular diz respeito à esperança de voltar a andar. Muitas vezes é utilizada a palavra "cura" para definir o "voltar a andar". 
Entretanto, ela também pode ser compreendida como algo que ultrapassa o "voltar a andar", como é indicado na fala abaixo:

Familiar 2: Aí ela fala pras pessoas: eu posso imaginar que ser curada não é só andar, porque às vezes as pessoas, a cabeça deles, a gente tem duas pernas e de cabeça não tem a menor. Não é verdade? O que adianta ter duas pernas, andar assim e...

$\mathrm{Na}$ avaliação passiva da deficiência, a pessoa com lesão medular, devido a todas as mudanças e limitações impostas pela lesão, tende a se perceber como incapacitado. Esta forma de enfrentamento pode ser observada no relato abaixo:

Familiar 1: Mas eles se sentem incapazes não é? Eles se sentem, porque quem viu meu filho, a vida que meu filho tinha, meu filho chegava a sexta-feira a noite, pegava o carro ó, viajava. Era a vida deles... Era a vida deles... Mas nem ligava pra mim, mãe eu tô bem! Não, era a vida deles!

A forma como o próprio membro deficiente lida com suas limitações pode ter uma grande influência na maneira do familiar encarar e enfrentar a deficiência deste membro. Tal constatação pode ser exemplificada no relato abaixo:

Familiar 2: agorinha mesmo ela [a esposa de um paciente] tava falando que ele entrou em depressão, porque tem gente que às vezes consegue controlar, e tem gente que já não consegue controlar né? Então falar assim... adianta eu me espernear né, e ficar aí, pra baixo? Tenho mais é que dar apoio, e ela me passa essa grande vontade, ela mesma acaba passando pra mim.

A seguir serão apresentados os resultados obtidos referentes ao Bloco Temático 4: Quanto a Reabilitação. 


\subsection{Bloco Temático 4: Quanto a reabilitação}

A reabilitação pode assumir significados diferenciados entre as pessoas acometidas por uma lesão medular. A maneira como entendem um processo de reabilitação, seus objetivos, métodos e efeitos encontra-se diretamente relacionada com as suas vivências, expectativas e conceitos formados durante o todo o seu percurso como lesado medular. Através da tabela 34, é possível visualizar como os entrevistados compreendem o significado do conceito reabilitação.

Tabela 34. Concepções sobre reabilitação.

\begin{tabular}{|c|c|c|c|}
\hline CONCEPÇÃO & CONTEÚDO & $\mathbf{P}$ & $\mathbf{F}$ \\
\hline \multirow{5}{*}{ Reabilitação Física } & $\begin{array}{l}\text { restabelecimento de funções corporais } \\
\text { (voltar a andar) }\end{array}$ & $2,3,4,6,9$ & 05 \\
\hline & fortalecimento corporal & 1,2 & 02 \\
\hline & manutenção corporal & 1,2 & 02 \\
\hline & melhorias de uma forma geral & 8 & 08 \\
\hline & & Subtotal & 17 \\
\hline \multirow{2}{*}{ Reabilitação Funcional } & maior independência como cadeirante & $3,5,7,9,10,11$ & 06 \\
\hline & & Subtotal & 06 \\
\hline \multirow{5}{*}{ Reabilitação Biopsicossocial } & acompanhamento clínico e psicossocial & 4,6 & 02 \\
\hline & aceitação de sua deficiência & 4 & 01 \\
\hline & prática de exercícios fisioterápicos & 4 & 01 \\
\hline & prática de atividade vocacional/profissional & 12 & 01 \\
\hline & & Subtotal & 05 \\
\hline \multirow{2}{*}{ Reabilitação Social } & \multirow[t]{2}{*}{ socialização } & 2 & 01 \\
\hline & & Subtotal & 01 \\
\hline & & Total & 28 \\
\hline
\end{tabular}

Como pode ser percebido na tabela 34, a reabilitação encontra-se relacionada, na sua maior parte, a uma conotação física (17 relatos). Nesta tabela, observam-se conceitos para "reabilitar" que variam entre tornar o indivíduo apto fisicamente ou mesmo ajudá-lo diretamente a adquirir as suas funções anteriores ao advento da lesão, no qual aparece com uma freqüência significativa em seus depoimentos (5 relatos). Logo em seguida, está a reabilitação funcional, ou seja, a possibilidade de uma maior independência no exercício de seus papéis sociais, profissionais e etc, na condição de deficiente físico e "cadeirante" (6 relatos). A reabilitação percebida no seu aspecto integral, considerando o indivíduo na sua totalidade biopsicossocial, aparece claramente destacada em cinco de seus relatos. Estas conceptualizações podem aparecer de forma concomitante, sem que uma delas, necessariamente, venha excluir a outra. Entretanto, a concepção de uma reabilitação quase 
que exclusivamente física e voltada para o restabelecimento das suas funções corporais, é predominante em seus depoimentos e pode ser exemplificada através dos seguintes relatos:

Pessoa 6: Voltar às minhas funções normais como era antes.

Pessoa 3: Então eu acho que a reabilitação envolve tudo, é muito boa. E a maior parte dela é realmente tentar restaurar o corpo. Ela não vai fazer milagre. Não dois, três, quatro anos, e vai sai andando, correndo e vai jogar futebol. Mas ela busca isso. É uma tentativa de buscar a reabilitação total da pessoa.

A consciência de que a reabilitação envolve o indivíduo como um todo, em toda a sua complexidade, é denotada com uma certa freqüência em seus relatos. Neste entendimento do que seja reabilitação, os aspectos físicos e psicossociais deveriam ser englobados através do trabalho de profissionais de diversas áreas de conhecimento. Entretanto, o uso exclusivo de exercícios fisioterápicos é também considerado por estas pessoas como sendo um tipo de reabilitação. Isto faz com que o conceito de reabilitação aborde uma grande amplitude de ações, das quais possuam propósitos que se aproximam entre si, mas não necessariamente englobando todas as metas que deveriam ser alcançadas no contexto reabilitacional, em seu conceito mais amplo. Nos casos em que a reabilitação encontra-se restrita à fisioterapia, estas pessoas podem se responsabilizar pelo seu próprio tratamento, utilizando-se de seu domicílio e de seus conhecimentos, como é afirmado no depoimento da Pessoa 2:

Pessoa 2: Então eu preferi assim, como eu já sei como cuidar do meu organismo, fazer os alongamentos eu não tenho a necessidade de pagar pra fazer fisioterapia num local. Porque eu sei o que eu faço com o meu organismo porque eu já aprendi. Então lá na fisioterapia eles davam os pesinhos pra exercitar meus braços e é treino. Eu fazia treino lá, eu treinava em casa...

Embora este tipo de intervenção possa ocorrer, o entrevistado acima acredita que o tratamento domiciliar não proporciona, ao indivíduo acometido por uma lesão medular os 
benefícios psicossociais obtidos através de um tratamento reabilitacional e institucional, como pode ser depreendido em seus depoimentos:

Pessoa 2: Você fazendo em casa você não vê outras pessoas. A partir do momento que você vai em algum local e vê alguém de cadeira, você pensa: Puxa, não sou só eu. Isso ajuda muito a parte psicológica da pessoa.

Com o propósito de contextualizar a vivência dos participantes desta pesquisa, a tabela 35 aborda o histórico reabilitacional dos entrevistados.

Tabela 35. Instituições reabilitacionais freqüentadas pelos entrevistados.

\begin{tabular}{|c|c|c|}
\hline PESSOA & INSTITUIÇÃO FREQUENTADA & $\begin{array}{c}\text { REABILITAÇÃO UTILIZADA } \\
\text { ATUALMENTE }\end{array}$ \\
\hline 1 & EENM - Casa Esperança - AACD & Fisioterapia em casa e hidroterapia - EENM \\
\hline 2 & Fisioterapia pela Unimed - Sarah Kubitscheck & Fisioterapia pelo SUS e EENM \\
\hline 3 & Fisioterapia em clínica-fisioterapia em casa & EENM \\
\hline 4 & AACD - físioterapia em clínica e acupuntura & Fisioterapia em clínica e EENM \\
\hline 5 & $\begin{array}{l}\text { Sarah Kubtscheck - fisioterapia no SESC - } \\
\text { fisioterapia em clínica-fisioterapia em casa }\end{array}$ & EENM \\
\hline 6 & $\begin{array}{l}\text { Fisioterapia em clínica - AACD } \\
\text { (para controle da espasticidade) }\end{array}$ & $\begin{array}{l}\text { Fisioterapia, hidroterapia e ecoterapia na Escola de } \\
\text { Educação Física da Polícia Militar - EENM }\end{array}$ \\
\hline 7 & $\begin{array}{c}\text { Divisão de Reabilitação do Hospital das Clínicas } \\
\text { (SP) - Centro de Reabilitação (SP) - Fundação } \\
\text { Celma - natação no CAIC - fisioterapia no SESI - } \\
\text { fisioterapia em casa }\end{array}$ & Fisioterapia em casa e EENM \\
\hline 8 & Fisioterapia na UNICAMP e fisioterapia na PUC & $\begin{array}{c}\text { Terapia ocupacional na PUC - fisioterapia na } \\
\text { UNICAMP e EENM }\end{array}$ \\
\hline 9 & $\begin{array}{c}\text { ABDR - fisioterapia em clínica - fisioterapia em } \\
\text { casa }\end{array}$ & EENM \\
\hline 10 & Nenhuma instituição freqüentada anteriormente & Fisioterapia na UNICAMP e EENM \\
\hline 11 & Hidroterapia - fisioterapia na UNICAMP & Hidroterapia - fisioterapia na UNICAMP - EENM \\
\hline 12 & $\begin{array}{c}\text { Fisioterapia em casa (atendimento clínico } \\
\text { domiciliar) }\end{array}$ & $\begin{array}{c}\text { Fisioterapia em casa (atendimento clínico } \\
\text { domiciliar) e EENM }\end{array}$ \\
\hline
\end{tabular}

Como pode ser avaliado por meio da tabela 35, a maior parte dos entrevistados já passou por algum processo reabilitacional antes de iniciar o tratamento no programa de EENM. Alguns fizeram somente a fisioterapia, outros participaram de um processo reabilitacional mais amplo em instituições, tais como, o Hospital Sarah Kubitscheck ou a AACD e, no caso da Pessoa 1, pode-se assinalar a utilização de EENM, embora por um período curto de tempo.Vale também ressaltar que grande parte destas pessoas continua realizando 
tratamentos que não se encontram vinculados ao programa de EENM e que possuem como meta algum tipo de reabilitação. Pode-se perceber, a partir de seus relatos, a ocorrência de experiências bastante diversificadas em relação às instituições de reabilitação como um todo. A partir de tais experiências, podem-se extrair avaliações destas instituições e seus procedimentos reabilitacionais, que variam entre uma maior ou menor aprovação destes participantes. Na tabela 36, pode-se apreender a avaliação dos entrevistados sobre as instituições reabilitacionais por eles freqüentadas.

Tabela 36. Avaliação dos entrevistados sobre as instituições reabilitacionais freqüentadas anteriormente.

\begin{tabular}{|c|c|c|c|c|c|}
\hline \multicolumn{4}{|c|}{ AVALIAÇÃO } & $\mathbf{P}$ & $\mathbf{F}$ \\
\hline \multirow{20}{*}{$\begin{array}{l}0 \\
0 \\
: \\
: \\
0 \\
0 \\
0 \\
0 \\
0 \\
0 \\
0 \\
0 \\
0 \\
0\end{array}$} & \multirow{17}{*}{ 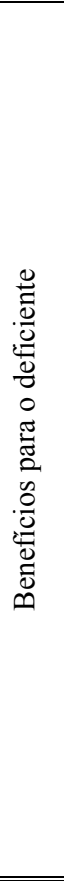 } & \multirow{9}{*}{ Físico } & fortalecimento muscular & 9,11 & 02 \\
\hline & & & manutenção da estrutura corporal & 7,12 & 02 \\
\hline & & & $\begin{array}{c}\text { realização de exames e avaliação } \\
\text { clínica }\end{array}$ & 2 & 01 \\
\hline & & & controle da espasticidade & 4 & 01 \\
\hline & & & $\begin{array}{c}\text { controle do esfíncter retal e tracto } \\
\text { urinário }\end{array}$ & 11 & 01 \\
\hline & & & aumento da sensibilidade & 11 & 01 \\
\hline & & & $\begin{array}{l}\text { maior capacidade de } \\
\text { movimentação }\end{array}$ & 11 & 01 \\
\hline & & & equilíbrio de tronco & 11 & 01 \\
\hline & & & & Subtotal & 10 \\
\hline & & \multirow{4}{*}{ Pessoal } & $\begin{array}{l}\text { maiores conhecimentos sobre a } \\
\text { lesão medular }\end{array}$ & 2 & 01 \\
\hline & & & incentivo a continuar a reabilitação & 5 & 01 \\
\hline & & & maior autoconfiança & 7 & 01 \\
\hline & & & & Subtotal & 03 \\
\hline & & Social & convivência com outros deficientes & $\begin{array}{c}5,7 \\
\text { Subtotal }\end{array}$ & $\begin{array}{l}02 \\
02\end{array}$ \\
\hline & & \multirow{2}{*}{ Funcional } & aprendizado de auto-cuidados & 7 & 01 \\
\hline & & & & Subtotal & 01 \\
\hline & & & & Subtotal & 16 \\
\hline & \multirow{2}{*}{\multicolumn{2}{|c|}{ Concepção }} & " abordagem integral do deficiente & 4 & 01 \\
\hline & & & & Subtotal & 01 \\
\hline & & & & Subtotal & 17 \\
\hline \multirow{5}{*}{ 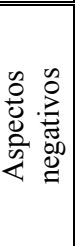 } & \multirow{2}{*}{\multicolumn{2}{|c|}{ Concepção }} & $\begin{array}{l}\text { falta de perspectiva } \\
\text { (concepção fatalista) }\end{array}$ & $4,7,9$ & 03 \\
\hline & & & & Subtotal & 03 \\
\hline & \multirow{2}{*}{\multicolumn{2}{|c|}{ Funcionamento }} & não tinha aparelhos adequados. & 1 & 01 \\
\hline & & & & Subtotal & 01 \\
\hline & & Subtotal & 04 \\
\hline \multirow{2}{*}{\multicolumn{4}{|c|}{ Apenas descreve as instituições frequentadas }} & $\begin{array}{c}3,5,6 \\
\text { Subtotal }\end{array}$ & $\begin{array}{l}03 \\
03\end{array}$ \\
\hline & & & & Total & 24 \\
\hline
\end{tabular}


Ao avaliarem as instituições reabilitacionais freqüentadas, os participantes desta pesquisa, ressaltam os aspectos positivos destas práticas (17 relatos), principalmente, no que condiz aos benefícios proporcionados ao deficiente.

Os benefícios físicos e pessoais aparecem na maior parte de suas declarações e podem ser exemplificados no depoimento abaixo:

Pessoa 2: Lá em Brasília o que foi mais útil pra mim foi esse conhecimento que eu não tinha. Qual era a altura da minha lesão... Foi lá no Sarah Kubitscheck. Foi lá, eu tive oportunidade de fazer vários exames, eu tirei vários raios $X$, eles viram como estava meu organismo.

Embora haja uma afirmação dos benefícios obtidos e da importância destas instituições reabilitacionais, em quatro dos relatos foram apontados os aspectos negativos referentes ao funcionamento destas instituições (falta de aparelhagem adequada) e, principalmente, no que se refere à filosofia ou concepção subjacente às ações reabilitacionais desenvolvidas. Neste sentido, pode-se apontar para a falta de perspectiva de uma possível recuperação, como é relatada na seguinte fala:

Pessoa 4: a única coisa que eu acho que falha na AACD é que eles não te dão uma perspectiva se você vai voltar ou não a andar. Pra eles todo mundo vai ficar numa cadeira de rodas e acabou. Isso dai eu acho que é uma falha. Porque mesmo que seja dificil, eu acho que a pessoa tem que ter uma esperança porque isso dai ajuda a pessoa a continuar lutando.

No relato acima, o entrevistado entende que este tipo de reabilitação está direcionado para aquelas pessoas que realmente aceitaram a sua deficiência como uma verdade inabalável, como um quadro que nunca será revertido. A inexistência de um real incentivo para que estas pessoas possam se locomover independentemente da cadeira de rodas, é uma das questões levantadas pelos entrevistados. De acordo com os seus relatos, a reabilitação exercida nestas instituições focaliza a independência da pessoa com lesão medular na sua 
condição de cadeirante. Ghirard (1999) afirma que as práticas reabilitacionais observadas nas instituições encontram-se estruturadas a partir de uma filosofia da eficiência. Elas baseiam-se na idéia de que o reabilitando precisa se tornar apto, o quanto antes, para que possa exercer atividades reconhecidamente produtivas. $\mathrm{O}$ objetivo da reabilitação, nestes casos, seria obter uma maior independência, a partir da aceitação por parte da pessoa com lesão medular de sua situação como algo irreversível, mas adaptável. No depoimento que se segue, a Pessoa 1 aborda estas questões:

Pessoa 1: Ah, no primeiro foi pouco, então eu tava ainda meio desnorteado do que era a lesão... mas a AACD eu digo que a reabilitação deles é muito boa, pra quem quer ficar na cadeira! Eles ensinam a sair da cadeira, entrar na cadeira, se vestir, se trocar, te deixam você legal, mas te dar um incentivo com aparelho pra vocêficar em pé não.

A negação da possibilidade de "ficar em pé" é vista pelos entrevistados como uma negação dos avanços científicos e é compreendida, portanto, como um comportamento ultrapassado, como é observado no seguinte relato:

Pessoa 1: Eu não sei se é porque é muita gente, a fila é grande, então, eles acabam... e tem um médico lá que tem uma idéia muito ultrapassada. Eu não vou dizer, não você vai sair correndo, não é isso... mas também vamos com calma né?

Diante dos resultados da tabela 36, nota-se a existência de benefícios adquiridos por estas pessoas por meio da reabilitação. Os principais benefícios relatados por eles, encontram-se caracterizados na tabela 37 .

Quanto aos benefícios adquiridos por meio de seu processo reabilitacional, pode-se constatar a alusão de inúmeros ganhos obtidos com as intervenções reabilitacionais, em todas as formas em que elas ocorreram. Tais ganhos abrangem os aspectos físicos/orgânicos, pessoais, funcionais e sociais. Alguns destes benefícios apareceram por ocasião da avaliação dos entrevistados sobre as instituições freqüentadas anteriormente (tabela 36). Os benefícios que abrangem os aspectos físicos aparecem com maior 
freqüência e se referem à manutenção de estabilidade orgânica (4 relatos), ao ganho de equilíbrio corporal, de força muscular, de movimentação e manutenção de massa corporal (todos com 2 relatos). Os benefícios que se referem à manutenção de uma estabilidade orgânica, constatada predominantemente em seus relatos, podem ser evidenciados no depoimento abaixo:

Pessoa 4: A manutenção do meu estado físico né? Que é bom, eu não tenho nenhum problema grave, só uma infecção de urina de vez em quando porque eu passo a sonda de alívio, então isso dai acontece...

Tabela 37. Principais benefícios adquiridos em seu processo reabilitacional.

\begin{tabular}{c||ccc}
\hline \multicolumn{1}{l|}{ BENEFÍCIO } & CONTEÚDO & P & F \\
\hline \hline \multirow{4}{*}{ Físico/ } & manutenção de estabilidade orgânica & $1,2,6,8$ & 04 \\
Orgânico & força muscular & 2,3 & 02 \\
& equilíbrio corporal & 3,6 & 02 \\
& manutenção de massa corporal & 1,8 & 02 \\
& maior movimentação & 1,2 & 02 \\
& maior sensibilidade & 5 & 01 \\
& melhoria física de uma forma geral & 8 & 01 \\
& & Subtotal & 14 \\
\hline \hline \multirow{4}{*}{ Pessoal } & mercepção mais realística e ampla das instituições & 2,4 & 02 \\
& reabilitacionais & 1,3 & 02 \\
& equilíbrio emocional & 4,6 & 02 \\
& melhor qualidade de vida & 4 & 01 \\
& esperança na recuperação de suas funções & 1 & 01 \\
& maior aceitação (defesa amadurecida) & 7 & 01 \\
& maiores conhecimentos sobre a lesão & 7 & 01 \\
& maior autoconfiança & 7 & 01 \\
& & Subtotal & 11 \\
\hline \hline \multirow{2}{*}{ Funcional } & maior independência nas atividades de vida diária & $5,8,9$ & 03 \\
& possibilidade de fazer transferências & 2,6 & 02 \\
& & Subtotal & 05 \\
\hline \hline \multirow{2}{*}{ Social } & convívio social mais adequado & 5 & 01 \\
& & Subtotal & 01 \\
\hline \hline
\end{tabular}

* método utilizado pelas pessoas com lesão medular para se transportarem de suas cadeiras de rodas para outros lugares, e vice-versa (como por exemplo, para a cama, vaso sanitário, outra cadeira e etc).

A independência nas atividades de vida diária é constatada em um número significativo de seus depoimentos e pode ser averiguada na fala que se segue:

Pessoa 5: Eles te ensinam o exercício de manipulação passiva, que é uma forma de você estimular a musculatura e adaptar o seguimento da corrente sanguínea, fazendo com que o 
sangue irrigue suas pernas pra não atrofiar, eles te ensinam a você sentar numa cadeira de rodas e sair, que é pra você ir num vaso sanitário, tomar banho, ir pra cama... sem que precise de alguém pra ajudar. Eles te ensinam a você transitar na rua. Então todo o processo, eu acho que ele é válido no ponto geral. Porquê ali tá a base de tudo, você aprende os exercícios, você aprende a lidar com a cadeira de rodas e você adquire a sua independência.

Os ganhos sociais foram destacados em apenas um dos relatos como benefícios adquiridos com o tratamento reabilitacional, possibilitando um convívio social mais amplo e não apenas entre as pessoas com deficiência, e pode ser observado a seguir:

Pessoa 5: É mais o convívio né, você aprende a conviver né?

Os tipos de benefícios (físicos, sociais e psicológicos) adquiridos com a reabilitação podem assumir valores diferenciados para cada pessoa. Os participantes desta pesquisa acreditavam que os benefícios pessoais encontram-se entre os ganhos mais importantes adquiridos durante o seu processo reabilitacional. O maior conhecimento sobre os procedimentos reabilitacionais e sobre as questões relacionadas com a lesão medular, foram aspectos considerados por eles como essenciais no tratamento reabilitacional. No relato que se segue, pode-se perceber esta relevância:

Pessoa 2: Lá em Brasília o que foi mais útil pra mim foi esse conhecimento que eu não tinha. Qual era a altura da minha lesão... Foi lá no Sarah. Foi lá, eu tive oportunidade de fazer vários exames, eu tirei vários raios $X$, eles viram como estava meu organismo, aprendi a fazer o cateterismo que foi algo muito importante porque hoje em dia eu me sinto muito bem fazendo ele porque eu não perco xixi e tenho controle da minha bexiga. E lá, assim a parte de fisioterapia eles falaram, colocaram a informação de que eu teria que continuar fazendo os exercícios pra manter as minhas pernas boas. 
A importância dos benefícios de convívio social, psicológicos e a percepção de um conjunto de aquisições importantes, onde todos os benefícios passam a adquirir o mesmo valor, também aparecem em suas falas, como pode ser observado no relato abaixo:

Pessoa 8: [O mais importante é...] o trabalho como um todo, o conjunto.

A maneira como esta reabilitação é conduzida é outra questão focalizada em alguns de seus relatos. De acordo com estas pessoas, a forma como o deficiente é acolhido, atendido, tratado, enfim, como ele é percebido dentro do ambiente reabilitacional, torna-se fator preponderante para o alcance dos objetivos de um programa de reabilitação. O próprio ambiente reabilitacional e suas condições são outros aspectos considerados importantes. Estes fatores podem ser destacados nas seguintes falas:

Pessoa 3: O mais importante é o tratamento do profissional.Principalmente o método que a gente é tratado aqui. E com educação, principalmente, que é o que mais ajuda também.

Pessoa 10: Eu acho que teria que ter clínica, um espaço.

A reabilitação, para estas pessoas, não se encontra somente restrita ao trabalho dos profissionais envolvidos, mas, ao contrário, trata-se de um trabalho onde o reabilitando possui um papel ativo em todo este processo. Os entrevistados acreditam que a crença deste reabilitando quanto a sua recuperação e suas ações para adquirir melhorias, são fatores imprescindíveis para que a reabilitação alcance seu êxito, como é destacado no relato que se segue:

Pessoa 6: Estar reabilitado seria a pessoa que sofreu o trauma, insistir na reabilitação. Ela querer. Eu quero fazer, eu quero andar, eu vou andar É diferente de você chegar e falar; Vou voltar a andar. E o outro responder: Ah, mas o médico já falou que não dá né, o outro médico já falou, sei lá quem sabe... O outro lá... me quebra, quebra! 
Neste depoimento é ressaltada a importância da contribuição daqueles que convivem com o deficiente para o seu sucesso reabilitacional, o que coincide com os resultados apresentados nas tabelas 29 e 30 . As expectativas de reabilitação, sejam elas quais forem, de acordo com suas falas, são compartilhadas com as pessoas mais próximas. Observa-se com isto a busca de um apoio e incentivo para continuarem lutando pela sua reabilitação total ou parcial.

No que diz respeito ao apoio encontrado fora do seu ambiente familiar e relacional, foram analisados nesta pesquisa, de forma particular, os serviços de assistência à saúde e a acessibilidade encontrada pelo deficiente físico na condição de prováveis usuários destes serviços. Observou-se que grande parte dos entrevistados não se defrontou com alguma dificuldade de acesso a esses serviços, como pode ser observado no seguinte depoimento:

Pessoa 4: Eu vou no oncologista direto. Se eu tenho uma infecção urinária eu sei. Vou no cardiologista direto ver como é que tá as funções. Então isso eu tenho acesso, graças a Deus.

Faz-se importante destacar que, em alguns casos específicos, tais dificuldades não ocorreram porque estas pessoas não chegaram a tentar utilizar esses recursos, como pode ser visualizado no seguinte relato:

Pessoa 2: Ah, eu tenho a Unimed, né? E graças a Deus tenho oportunidade de fazer os meus exames e tenho um convênio médico. Quanto a isso eu não tive dificuldades não. Assim, pros exames de urina e fezes eu faço pela Unimed. Não fisioterapia porque eles cortaram. Então mesmo que eu vá procurar fazer eu só vou fazer trinta dias, somente em um ano.

Os impedimentos para se utilizar uma assistência pública direcionada aos problemas de saúde, foram abordados em três dos relatos, como pode ser exemplificado no seguinte depoimento: 
Pessoa 3: Já. Quando eu precisei tirar as tomografias e fazer uma ressonância. Foi muito complicado.

De acordo com Gonzales (2000), a eficácia do processo reabilitacional encontra-se diretamente relacionada com a efetiva realização de uma rede de suporte social, conforme já mencionado, formada por organizações públicas de saúde, onde o deficiente possa contar com um atendimento que seja adequado às suas necessidades. No entanto, pode ser observada, em alguns depoimentos, a percepção da importância de uma participação ativa destas pessoas, também para conseguir apoio. Sua relevância é confirmada a partir do seguinte relato:

Pessoa 6: É porque eu não desisto. Eu vou atrás. Eu vou no coronel, eu vou no comandante geral, já fui até no governador. O máximo que ele vai falar é não. Então eu vou no presidente. Aí você pergunta: Será que ele chega no presidente? Eu chego no presidente. Quando eu fui me atenderam no mesmo dia, na mesma hora, nem marquei consulta.

A partir de todas estas considerações trazidas pelos entrevistados sobre a reabilitação, de uma forma geral, pode-se denotar uma aproximação entre alguns comportamentos e reações junto ao processo reabilitacional, já detectados em estudos que tiveram como foco a pessoa com lesão medular. Dewis (1989), ao analisar grupos de jovens com lesão medular, percebeu a existência de uma necessidade por parte destas pessoas em buscar, de alguma forma, uma vida que possa estar bem próxima do que eles entendem como normal. A autora constatou que esforços em direção a esta normalidade e conseqüente aceitação social, encontram-se ligados a algumas estratégias deliberadamente voltadas para o alcance de melhorias em três áreas principais, a saber, aparência física e funcionamento; independência emocional e física; habilidades sociais e/ou relacionamentos interpessoais. Percebe-se, portanto, no estudo aqui apresentado, a ocorrência destes esforços não somente com o intuito de uma maior aceitação e reconhecimento social, mas também como uma forma de estar saudável e com possibilidades de ter um número maior de experiências que, 
devido à lesão, tornaram-se um tanto quanto inacessíveis, se não, muito difíceis de serem vivenciadas.

A seguir, são apresentados os resultados obtidos no Bloco Temático 5: Concepções e expectativas em relação a EENM.

\subsection{Bloco Temático 5: Concepções e expectativas em relação à EENM}

No Brasil, a EENM vem sendo utilizada ainda na condição de pesquisa, para reabilitação de pessoas com uma lesão medular, caracterizada por uma tetraplegia ou paraplegia, contemplando um pequeno número de pacientes que se propõe a participar deste tratamento. Por este motivo, esta pesquisa tem como propósito compreender como estas pessoas tiveram acesso a este programa, assim como, o motivo que as levaram a buscar este tipo de tratamento e também o que as fizeram continuar. Outros aspectos abordados se referem ao conhecimento e informações que estas pessoas possuem sobre o tratamento através da EENM e as mudanças ocorridas em suas vidas, por meio deste tipo de intervenção reabilitacional. As expectativas em relação ao tratamento com a EENM também foram enfocadas, ressaltando-se, porém, que as mesmas puderam sofrer modificações ao longo de todo o período reabilitacional. Este fator foi considerado neste estudo, já que os entrevistados foram questionados sobre quais seriam suas expectativas antes de iniciar o tratamento, se as mesmas sofreram alguma alteração no decorrer do mesmo e quais seriam suas expectativas atuais. A ultima questão analisada se refere ao programa propriamente dito e teve como perspectiva compreender qual a percepção que estas pessoas possuíam do mesmo. Trata-se, como visto anteriormente, de um tratamento através da EENM, com freqüência semanal e finalidades científicas. Iniciou-se no ano de 1989 e é composto por uma equipe multidisclipinar, como visto anteriormente, sendo, na sua maior parte, pesquisadores coordenados pelo Prof. Dr. Alberto Cliquet Júnior. Uma de suas características é a sua larga rotatividade, já que estes profissionais e pesquisadores possuem apenas um interesse e comprometimento científico com este tratamento. 
Os entrevistados realizaram uma avaliação do funcionamento do programa supracitado, da sua equipe profissional e da importância da inserção do profissional psicólogo nesta equipe. Ainda sobre a inclusão da psicologia como área de atuação possível e necessária, os entrevistados responderam sobre como entendem que a psicologia deve ser exercida neste contexto, levando-se em consideração a população contemplada e o tipo de tratamento reabilitacional proposto.

A maneira como os entrevistados entraram em contato com este tipo de reabilitação é apresentada na tabela 38 .

Tabela 38. Como tiveram acesso à EENM.

\begin{tabular}{ccc||ccc}
\hline GRUPO 1 & \multicolumn{5}{c}{ GRUPO 2 } \\
\hline \hline ACESSO & P & F & ACESSO & P & F \\
\hline \hline divulgação na mídia (revista e TV) & $2,4,6$ & 03 & divulgação na mídia (revista e TV) & $7,9,12$ & 03 \\
pesquisas na internet & 1,5 & 02 & encaminhamento médico & $8,11,12$ & 03 \\
indicação de conhecidos & 1 & 01 & indicação da equipe hospitalar & 10 & 01 \\
encaminhamento médico & 6 & 01 & & & \\
\hline \hline
\end{tabular}

Grande parte das pessoas que procura o tratamento através da EENM acaba tomando conhecimento sobre sua existência de maneira bem diversificada, predominando nos dois grupos analisados, o acesso através de divulgação na mídia (6 relatos). $\mathrm{O}$ encaminhamento médico aparece com um relato no grupo 1 e três relatos no grupo 2, o que evidencia um crescente aumento de interesse no meio médico, por este tipo de reabilitação. A existência da indicação da equipe hospitalar somente no grupo 2 contribui para a confirmação de tal evidência. Observou-se, ainda, que o grupo 2, parece não possuir, ou mesmo não usufruir do acesso a outros meios de comunicação, como por exemplo, a internet. Este fato pode estar sinalizando uma maior abrangência de usuários em relação a este programa, já que o mesmo passou a incluir pessoas com níveis sócio-econômico diferenciados.

Os motivos apresentados para estarem realizando tal tratamento podem ser contempladas na tabela 39. 
Tabela 39. Motivos apresentados para participarem do Programa de EENM.

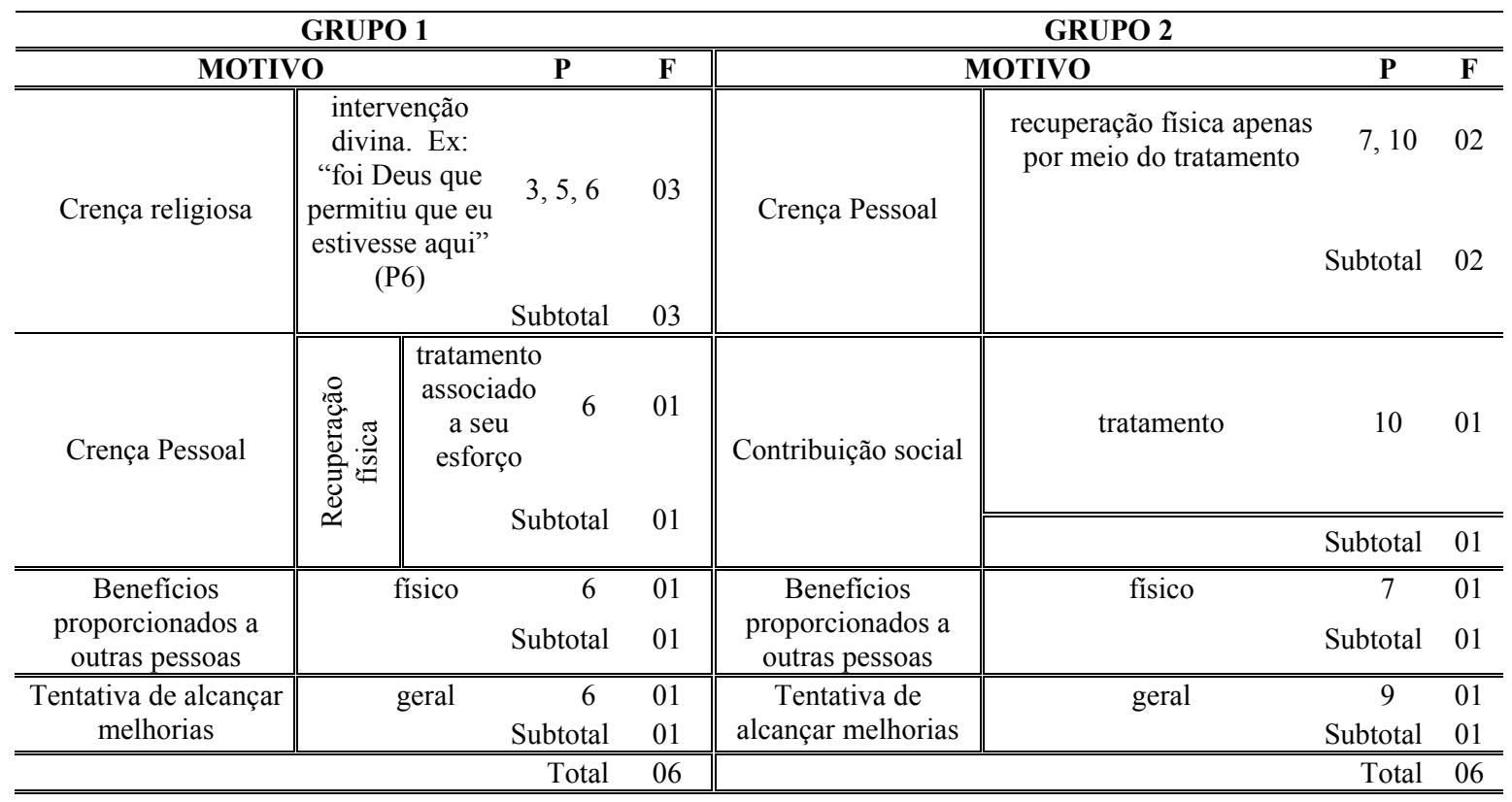

De acordo com a tabela 39, para os integrantes do grupo 1, há uma predominância de respostas referentes à crença religiosa, enquanto que para o grupo 2, prevalecem as crenças pessoais. Nos resultados referentes ao grupo 1, a crença na recuperação, ou simplesmente na possibilidade de estar buscando esta recuperação, ou o referido programa, não se encontra apenas focalizada nos avanços da medicina, mas mostra-se estar sustentada pela fé em um poder divino, como pode ser percebido no seguinte depoimento:

Pessoa 6: É porque Deus prepara isso, Deus é pai. Faço meus tratamentos... tudo que eu tenho feito... intermédio, primeiramente Deus, depois ele coloca as pessoas certas pra me auxiliar, coloca um pra me auxiliar ali, outro pra me auxiliar lá, secretário de segurança me auxiliar ali... são pessoas assim... autoridades mesmo... não é... não dizendo que as autoridades são melhores, não é isso. Mas são as autoridades mesmo que tem me auxiliado. São pessoas que Deus preparou pra isso. Até mesmo a viatura! Sem contar que eu não venho nas coisas por acaso. Ah, aquilo ali é por acaso... não! É sorte... não! É Deus! Porque Deus que me deu essa porta aqui. Foi Deus que permitiu que eu estivesse 
aqui. Então se eu não fizesse aqui, se eu estivesse na minha casa, por exemplo, agora, aí lá em cima né, Deus questionava né: Pô, eu abro a porta pro cara e o cara não quer.

Já em relação às pessoas que faziam parte do grupo 2, a crença em sua recuperação, devido à confiança neste tipo de tratamento, torna-se o motivo principal para sua participação, o que aponta para uma valorização cada vez maior do reconhecimento científico do tratamento ao qual estas pessoas se direcionam. É importante ressaltar a diferença de percepção entre estes dois grupos quanto aos fatores que irão contribuir para o êxito deste tipo de reabilitação, já que somente no grupo 1, um dos entrevistados se refere à importância de sua participação no alcance dos objetivos reabilitacionais. Esta percepção parece mostrar que o tempo de tratamento pode exercer uma maior consciência destas pessoas quanto ao seu papel como "ser ativo", dentro do contexto de reabilitação em que se encontram. É importante lembrar que, na tabela 5, os entrevistados apontam para uma concepção na qual qualquer tipo de recuperação obtida encontra-se relacionada, principalmente, ao apoio familiar, ao seu próprio esforço e/ou crença pessoal.

A contribuição social exercida por essas pessoas no momento em que se tornam usuários deste tipo de tecnologia, somente é relatada por um entrevistado, pertencente ao grupo 2 , revelando, embora muito timidamente, o aparecimento de motivos que vão além dos seus interesses pessoais, com um caráter de participação social, como pode ser evidenciado em seu relato:

Pessoa 10: Ou uma pesquisa, não pra mim voltar a andar, mas tem muita criança que não conhece o que é andar. Se for uma pesquisa, eu me colocaria pra fazer uma pesquisa que não dê acesso pra mim andar, mas pra outros andarem. Isso é importante!

Os motivos relatados com menor freqüência, nos dois grupos, para estarem freqüentando a EENM, são aqueles relacionados com os benefícios alcançados por outras pessoas com a utilização deste tratamento e a tentativa de alcançar melhorias. Tais motivos são observados nos seguintes discursos: 
Pessoa 5: E aí teve um relato lá que um rapaz voltou a andar com esse estímulo. Inclusive ele era de Paulínia. Não cheguei a conhecê-lo, mas ele era de Paulínia. E como minha lesão é incompleta, então eu pensei: Se esse cara andou eu vou lá e vou tentar, de repente eu consigo andar também.

Pessoa 6: Isso aqui é um estudo, é um estudo, tudo bem, mas e ai pode dar certo? Pode, como também não pode. Prejudicar vai? Não. Não pode prejudicar. Se começar a me prejudicar eu paro. É a lógica. Piorar eu não vou. Eu tô melhorando... se eu não voltar a andar, pelo menos eu tô melhorando. Piorar eu não vou.

A situação em que os entrevistados se encontravam no Programa de EENM, quando foi realizada esta pesquisa, é contemplada na tabela 40.

Tabela 40. Situação no Programa de EENM.

\begin{tabular}{cc||cc}
\hline \multicolumn{2}{c}{ GRUPO 1 } & \multicolumn{2}{c}{ GRUPO 2 } \\
\hline \hline FICA DE PÉ E & FAZ SOMENTE & FICA DE PÉ E & FAZ SOMENTE \\
REALIZA A MARCHA & EXERCÍCIO & REALIZA A MARCHA & EXERCÍCIO \\
\hline Pessoa 1 & & & Pessoa 8 \\
Pessoa 2 & Pessoa 5 & Pessoa 7 & Pessoa 10 \\
Pessoa 3 & Pessoa 9 & Pessoa 11 \\
Pessoa 4 & & & Pessoa 12 \\
Pessoa 6 & & Subtotal: 02 & Subtotal: 04 \\
Subtotal: 05 & Subtotal: 01 & & Total: 06 \\
\hline \hline
\end{tabular}

Observa-se, por meio da tabela 40, que, no caso do grupo 1, quase todos os entrevistados, exceto a Pessoa 5, estavam sendo contemplados com um dos objetivos da tecnologia oferecida pelo uso da EENM, que se constitui em fazer a pessoa caminhar artificialmente através de eletrodos e aparelhos como estimuladores desenvolvidos pelo grupo de pesquisas do LABCIBER - Laboratório de Biocibernética e Engenharia de Reabilitação - da Escola de Engenharia de São Carlos - USP. Já no que se refere à situação dos integrantes do grupo 2, este quadro de inverte. Somente as Pessoas 7 e 9 encontravam-se em condições de ficar de pé e exercer a marcha. Isto ocorre devido à diferença de tempo em que estas pessoas encontram-se no tratamento. Outro motivo, também bastante relevante, diz respeito ao nível de lesão, já que se observa a predominância no grupo 2, de pessoas acometidas por uma 
tetraplegia, o que dificulta de forma preponderante o exercício da marcha, considerando que, nestes casos, os membros superiores também foram afetados pela lesão.

Os conhecimentos adquiridos por estas pessoas sobre a EENM e seu procedimento reabilitacional foram, também, focalizados nesta pesquisa. Elas foram questionadas sobre a existência ou não de acesso relativo às informações sobre a EENM, neste programa, e suas respostas foram diversificadas. Tais respostas encontram-se representadas na tabela 41 .

Tabela 41. Acesso aos conhecimentos referentes à EENM, obtidos no Programa de EENM.

\begin{tabular}{|c|c|c|c|c|}
\hline \multicolumn{5}{|c|}{ GRUPO 1} \\
\hline ACESSIBILIDADE & \multicolumn{2}{|c|}{ FORMA DE OBTENÇÃO } & $\mathbf{P}$ & $\mathbf{F}$ \\
\hline \multirow{4}{*}{$\begin{array}{l}\text { A informações } \\
\text { incompletas }\end{array}$} & \multirow{4}{*}{$\begin{array}{l}\text { Busca de } \\
\text { informações }\end{array}$} & $\begin{array}{c}\text { consulta aos } \\
\text { profissionais }\end{array}$ & 2,4 & 02 \\
\hline & & artigos de revistas & 2 & 01 \\
\hline & & buscas na internet & & 01 \\
\hline & & & Subtotal & 04 \\
\hline \multirow{4}{*}{$\begin{array}{l}\text { A todas as } \\
\text { informações } \\
\text { necessárias }\end{array}$} & \multirow{4}{*}{\multicolumn{2}{|c|}{$\begin{array}{c}\text { orientação - entrevista inicial } \\
\text { palestras inseridas no programa } \\
\text { experiência obtida com o } \\
\text { tratamento }\end{array}$}} & 5 & 01 \\
\hline & & & 3 & 01 \\
\hline & & & 1 & 01 \\
\hline & & & Subtotal & 03 \\
\hline & & & Total & 07 \\
\hline \multicolumn{5}{|c|}{ GRUPO 2} \\
\hline ACESSIBILIDADE & \multicolumn{2}{|c|}{ FORMA DE OBTENÇÃO } & $\mathbf{P}$ & $\mathbf{F}$ \\
\hline \multirow{4}{*}{$\begin{array}{l}\text { A informações } \\
\text { incompletas }\end{array}$} & \multirow{4}{*}{$\begin{array}{l}\text { Busca de } \\
\text { informações }\end{array}$} & $\begin{array}{c}\text { consulta aos } \\
\text { profissionais }\end{array}$ & 8,11 & 02 \\
\hline & & observação & 8,11 & 02 \\
\hline & & artigos de revistas & 12 & 01 \\
\hline & & & Subtotal & 05 \\
\hline \multirow{2}{*}{\multicolumn{3}{|c|}{ Não obteve informações }} & 9,10 & 02 \\
\hline & & & Subtotal & 02 \\
\hline \multirow{3}{*}{$\begin{array}{l}\text { A todas as } \\
\text { informações } \\
\text { necessárias }\end{array}$} & \multirow{2}{*}{\multicolumn{2}{|c|}{ palestras inseridas no programa }} & 7 & 01 \\
\hline & & & Subtotal & 01 \\
\hline & & & Total & 08 \\
\hline
\end{tabular}

$\mathrm{Na}$ maior parte dos casos, tanto no que se refere ao grupo 1, quanto ao grupo 2, fica notória uma dificuldade na obtenção e compreensão destas informações, ressaltando-se que o grupo 2, encontrou maior número de dificuldades em adquirir ou compreender tais informações. É importante, também, chamar a atenção para um dos relatos de dois dos entrevistados, integrantes do grupo 2, que afirmaram não terem tido acesso a algum tipo de informação sobre a tecnologia implantada através da EENM: 
Pessoa 9: Nenhuma. Ninguém nunca conversou comigo sobre isso

Os dois grupos revelaram, através destes depoimentos, a necessidade de estarem indagando ou explorando melhor as questões relativas à EENM, de outras formas, como por exemplo, através de perguntas diretas, por meio de contatos com pessoas que dominam o assunto e profissionais da área (4 relatos) ou valendo-se da observação durante o próprio tratamento (aparecendo apenas no grupo 2, com 2 relatos). A consulta a artigos de revistas é comum nos dois grupos (1 relato em cada) e as buscas na internet foram exclusivas ao grupo 1, conforme indicado na tabela 38. O esclarecimento através de consultas (freqüente nos dois grupos), e as dificuldades em obter informações ficam claramente configurados nas falas destas pessoas:

Pessoa 2: Eu acho assim, isso aí quando eu tenho alguma dúvida eu pergunto. Tem algumas coisas que às vezes eles falam que eu ainda não sei o que significa direito. Até o Dr. Cliquet já fez palestras mostrando pessoas que já tiveram grandes benefícios, então eu to aí né? É uma vez por semana, a gente vem e conversa com as pessoas que estão aqui. Tem algumas reportagens que saíram em revistas, mas eu acho que eles deviam colocar um painel, mostrando assim: saiu na revista tal. Porque as vezes fala boca a boca e você acaba esquecendo da revista pra anotar... Porque as vezes sai em alguma reportagem e saiu em tal revista, você pega compra, torna isso mais próximo de você, do seu dia dia, porque se no dia de amanhã você encontra uma pessoa de cadeira que não tenha oportunidade de vir aqui porque não tem conhecimento, você fala: Olha, essa revista aqui tem essa reportagem. Então você já vai passando essa informação pra outras pessoas.

Como se pode inferir no relato de P2 e P9, os recursos para se obter as informações sobre a EENM nem sempre se encontram disponibilizados. O interesse em ter uma maior acessibilidade às informações existentes sobre a EENM aparece em algumas de suas falas, tornando-se um dado importante para que o programa de EENM possa alcançar maior êxito no atendimento desta população, visto que o conhecimento destas pessoas sobre este tratamento é um fator fundamental na aceitação e compreensão das reações induzidas pelo mesmo. Ainda analisando o relato anterior, percebe-se uma preocupação por parte destas 
pessoas em estar disponibilizando este tipo de conhecimento para àqueles que não possuem algum tipo de contato com as informações existentes sobre os tratamentos mais recentes que se encontram direcionados às pessoas acometidas por uma lesão medular. Em uma situação oposta, observa-se a afirmação de uma preocupação por parte do referido programa em estar fornecendo informações sobre os efeitos já obtidos com este tratamento, indicando, portanto, uma falha em conscientizar estas pessoas sobre o que é EENM, e para quê ela existe. Este fato pode ser depreendido do relato que se segue:

Pessoa 6: Não. Isso é o básico meu. Que deu certo eu já vi. O professor já comprovou que deu certo em alguns pacientes. Você vê pela [paciente], que não mexia nada e mexeu o pezinho lá. Tá comprovado, tô certo?

Embora eles entendam e acreditem na eficácia deste programa, um aspecto essencial a ser debatido, com vistas a uma melhor orientação a estas pessoas, diz respeito ao caráter científico deste programa. $\mathrm{O}$ fato de terem sido devidamente esclarecidos sobre este aspecto e, portanto, de que entendiam que se tratava de uma pesquisa, sem garantias de uma recuperação total ou de um tempo determinado para que ela ocorresse, foi ressaltado no depoimento que se segue:

Pessoa 1: Sim. Não é milagroso, não é nada disso...é uma pesquisa que já teve resultados e ta trabalhando em cima disso

Em um menor número de relatos (1 resposta cada), eles afirmaram terem adquirido todas as informações necessárias por meio de palestras inseridas no próprio programa (presentes no grupo 1 e 2), orientação recebida ao iniciar o tratamento ou através da própria experiência com este tipo de tratamento. Estas duas últimas somente apresentadas pelas pessoas do grupo 1.

A concepção dos entrevistados sobre a EENM pode ser compreendida a partir dos relatos que se encontram evidenciados na tabela 42. 
Tabela 42. Concepções sobre a EENM.

\begin{tabular}{|c|c|c|c|c|c|}
\hline \multicolumn{6}{|c|}{ GRUPO 1} \\
\hline CONCEPÇÃO & $\begin{array}{c}\text { LOCAL } \\
\text { ESTIMULADO }\end{array}$ & & EFEITO & $\mathbf{P}$ & $\mathbf{F}$ \\
\hline \multirow{17}{*}{ 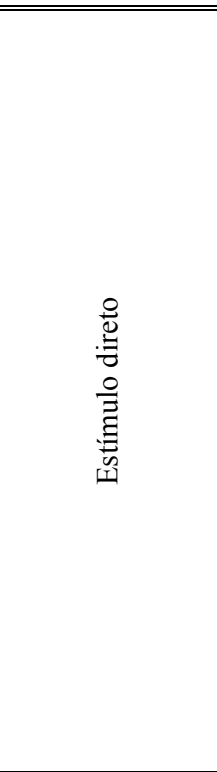 } & \multirow{8}{*}{ músculo } & \multirow{5}{*}{ secundário } & $\begin{array}{l}\text { reforça a musculatura } \\
\text { aumento do tônus muscular }\end{array}$ & $\begin{array}{l}1,4,5 \\
4,5\end{array}$ & $\begin{array}{l}03 \\
02\end{array}$ \\
\hline & & & prevenção de osteoporose & 5 & 01 \\
\hline & & & $\begin{array}{l}\text { manutenção de massa muscular } \\
\text { (prevenção de atrofia) }\end{array}$ & 5 & 01 \\
\hline & & & $\begin{array}{l}\text { manutenção da circulação } \\
\text { (irrigação sanguínea) }\end{array}$ & 5 & 01 \\
\hline & & & & Subtotal & 08 \\
\hline & & \multirow{2}{*}{ primário } & \multirow[t]{2}{*}{ contração muscular } & 1 & 01 \\
\hline & & & & Subtotal & 01 \\
\hline & & & & Subtotal & 09 \\
\hline & \multirow{5}{*}{ medula } & \multirow[t]{2}{*}{ primário } & \multirow[t]{2}{*}{ contração muscular } & 3 & 01 \\
\hline & & & & Subtotal & 01 \\
\hline & & \multirow{2}{*}{ secundário } & \multirow[t]{2}{*}{ criação de uma nova passagem nervosa } & 2 & 01 \\
\hline & & & & Subtotal & 01 \\
\hline & & & & Subtotal & 02 \\
\hline & \multirow{3}{*}{ cérebro } & \multirow{2}{*}{ primário } & \multirow[t]{2}{*}{ contração muscular } & 6 & 01 \\
\hline & & & & Subtotal & 01 \\
\hline & & & & Subtotal & 01 \\
\hline & & & & Subtotal & 12 \\
\hline \multirow{6}{*}{ 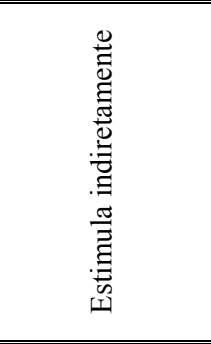 } & \multirow{3}{*}{ medula } & \multicolumn{2}{|c|}{$\begin{array}{c}\text { criação de um "campo secundário" } \\
\text { (um novo caminho para a passagem de células nervosas) }\end{array}$} & 5,2 & 02 \\
\hline & & \multirow{2}{*}{\multicolumn{2}{|c|}{$\begin{array}{l}\text { restituição de suas funções motoras. } \\
\text { Ex: "reaprender os movimentos" (P4) }\end{array}$}} & 3,4 & 02 \\
\hline & & & & Subtotal & 04 \\
\hline & \multirow{2}{*}{ cérebro } & \multirow{2}{*}{\multicolumn{2}{|c|}{$\begin{array}{l}\text { restituição das células nervosas atingidas pela lesão } \\
\text { "reaprendizagem" das funções motoras }\end{array}$}} & 3 & 01 \\
\hline & & & & Subtotal & 01 \\
\hline & & & & Subtotal & 05 \\
\hline & & & & Total & 17 \\
\hline \multicolumn{6}{|c|}{ GRUPO 2} \\
\hline CONCEPÇÃO & $\begin{array}{c}\text { LOCAL } \\
\text { ESTIMULADO }\end{array}$ & & EFEITO & $\mathbf{P}$ & $\mathbf{F}$ \\
\hline \multirow{6}{*}{ Estímulo direto } & \multirow{5}{*}{ músculo } & \multirow{2}{*}{ primário } & \multirow[t]{2}{*}{ contração muscular } & 9,11 & 02 \\
\hline & & & & Subtotal & 02 \\
\hline & & \multirow{2}{*}{ secundário } & reforça a musculatura & 12 & 01 \\
\hline & & & & Subtotal & 01 \\
\hline & & & & Subtotal & 03 \\
\hline & & & & Subtotal & 03 \\
\hline & medula & $\begin{array}{r}\mathrm{Cr} \\
\text { (um novo ca }\end{array}$ & $\begin{array}{l}\text { ç̃o de um "campo secundário" } \\
\text { nho para a passagem de células nervosas) }\end{array}$ & 11 & 01 \\
\hline $\begin{array}{l}\text { Estimula } \\
\text { indiretamente }\end{array}$ & meaura & & tuição de suas funções motoras & 7 & 01 \\
\hline & & & & Subtotal & 02 \\
\hline & & & & Subtotal & 02 \\
\hline & & Não poss & & 8,10 & 02 \\
\hline & & & & Subtotal & 02 \\
\hline & & & & Total & 07 \\
\hline
\end{tabular}


A tabela 42 revela várias maneiras de entender o que é EENM, incluindo uma gama de teorias. Observou-se que, embora houvesse uma concordância de que a EENM é realizada através de um estímulo elétrico, tornou-se perceptível duas maneiras de compreender a atuação destes estímulos que se caracterizaram como direta ou indireta. Esta ultima sendo conseqüência da insistência na aplicação dos estímulos diretos. Seus relatos também se diversificaram quanto ao local onde este estímulo atuava. Para grande parte dos entrevistados, incluindo os do grupo 1 e 2, o estímulo elétrico atinge diretamente o músculo, produzindo efeitos primários (contração muscular) mais evidentes para o grupo 2 , e, secundários, com maior ênfase no grupo 1. Neste grupo, os efeitos secundários são citados na maior parte dos relatos (8 relatos) e se referem ao reforço da musculatura (3 relatos), aumento do tônus muscular (2 relatos), prevenção da osteoporose (1 relato), manutenção da massa muscular, evitando atrofias (1 relato) e manutenção da irrigação sanguínea (1 relato). Observa-se, no entanto, que o tempo em que estas pessoas se utilizam da EENM é um fator preponderante quando relacionado com os resultados secundários observados, o que pode denotar uma concepção da EENM marcada pela ocorrência destes efeitos, como pode ser percebido no seguinte relato:

Pessoa 5: É um estímulo direto no músculo, no qual ele reforça a musculatura, ele te dá mais tônus muscular e conseqüentemente ele te ajuda na... Não deixa que você tenha uma osteoporose, não deixa que a sua perna fique atrofiada, mantém a irrigação sanguínea...

No grupo 2, apenas uma resposta se refere a um efeito secundário no que diz respeito a uma maior força muscular.

De acordo com seus relatos, entende-se que além de estimular o músculo com o objetivo de exercer o movimento, este estímulo pode também assumir uma outra função ainda mais complexa, que se constituiria em auxiliar o organismo, possibilitando o alcance de uma nova maneira para que o estímulo nervoso volte a executar o seu percurso natural, podendo ter sua origem no cérebro (uma resposta no grupo 1) ou, de acordo com seis das respostas, incluindo o grupo 1 e 2, na medula, e se direcionando aos músculos periféricos ou viceversa. A EENM pode ser compreendida como um tipo de estímulo que proporciona as 
condições para que o organismo encontre uma outra maneira de alcançar o movimento dos membros superiores e inferiores. Esta crença na formação de um "novo caminho" para que os estímulos possam percorrer, pode ser exemplificada no depoimento que se segue:

Pessoa 5: e eu acredito que o estímulo neuromuscular, ele, devido à insistência do estímulo a medula, de tanto insistir, a medula tem um campo secundário, isso eu li num livro de um fisioterapeuta, que ela tem um campo secundário e ela passa a fazer o trabalho através desse campo, então você volta a ter movimento de perna, sensibilidade e tal. Mas isso com a insistência do estímulo. Por isso é que eu vim, e eu acredito que as pessoas que estão tendo recuperação, que são tetras e que já estão tendo movimento de braço, a senhora que tava ali, ela tem movimento de pé, tudo devido ao estímulo, porque a medula ela vai criando esse campo. E eu acredito muito que esse tratamento que o Cliquet tá aplicando aqui é um dos tratamentos mais eficazes que tem para a lesão medular no momento.

Ainda analisando tais concepções referentes à EENM, o estímulo pode funcionar com o intuito de fazer com que o binômio cérebro/medula retorne às suas funções normais, como era anteriormente ao advento da lesão (restituição das células nervosas atingidas pela lesão), com uma resposta e somente no grupo 1 . Ou, então, que a medula volte de forma independente, através dos estímulos, exercendo as funções que lhe foram subtraídas (2 respostas no grupo 1 e uma resposta no grupo 2). De acordo com esta lógica, explícita nos depoimentos abaixo, supõe-se que, em algum momento, as funções motoras, perdidas com a lesão medular, possam retornar apenas com o exercício constante dos estímulos elétricos neuromusculares:

Pessoa 4: Bom, é o que vocês me falam né? É pra ativar a musculatura, pra manter a musculatura forte e fazer a medula, na parte de baixo da lesão, reaprender os movimentos. Isso dai mais pra frente, volta a funcionar sozinho. Não que você controle, mas eu acho que a medula é que vai voltar a fazer a função dela.

Todas estas afirmações referem-se, de alguma maneira, a uma reorganização do organismo no sentido de recuperar as funções lhe foram subtraídas com a lesão medular, como 
apontado por Cliquet (2003), ao relatar a neuroplasticidade como um dos efeitos provenientes do tratamento com a EENM. Em uma outra visão (aparecendo em três dos relatos do grupo 1 e não estando presente no grupo 2), mais distante dos efeitos concretos e reais da EENM, há a afirmação de que o estímulo elétrico neuromuscular ativado e direcionado ao músculo, poderia estimular diretamente, não somente o músculo e os nervos, como também, a medula e o cérebro. O depoimento, abaixo, ilustra este quadro:

Pessoa 6: Deduzo que quando você leva um choque na perna, o choque automaticamente, acho que é mais rápido que a luz. Ele vem no cérebro. O cérebro capta esse choque e manda pra medula. Aí faz aquela troca, faz aquele giro. Perna cabeça, cabeça-medula, medula o membro. E a minha medula, tem que receber a informação, assim: Levanta a perna aí. Levanta outra perna agora. Agora chuta... Eu pensei nisso.

Embora no grupo 2 as concepções acima não estejam presentes, observou-se a ocorrência de dois depoimentos apontando para um total desconhecimento sobre esta tecnologia. Estas pessoas, ao serem questionadas em relação ao que entendiam por EENM, não responderam esta questão com a justificativa de que nada sabiam sobre esse assunto, confirmando portanto, os dados apresentados na tabela 41, relativas ao acesso aos conhecimentos referentes a EENM (informações incompletas e ausência de informações). De acordo com alguns autores como Bradley (1994); Triolo, Kobetic e Betz (1996), o desconhecimento sobre a EENM pode se refletir em reações marcadas por uma inconstância quanto a aceitação, reconhecimento e assiduidade ao tratamento, dificultando, portanto, a obtenção de resultados satisfatórios. O relato abaixo ilustra esta carência de informações:

Pessoa 10: Nada. Não entendo muito não. Uns falam uma coisa, outros falam outra.

A concepção de que a EENM pode também proporcionar as condições corporais para que eles possam ficar em pé e andar, está presente no seguinte relato:

Pessoa 2: mas eu acho que tem ajudado muitas pessoas né, está ajudando, está tendo progressos, então acredito que vindo aqui, fazendo estimulação logo o meu organismo vai 
se acostumar. Coisa que eles falaram. O meu nervo vai se acostumando a este estímulo que vai facilitar pra você ter uma coordenação motora na hora que você ficar de pé e andar. Eu acho que é mais ou menos isso.

As mudanças ocorridas em suas vidas, devido ao tratamento com a EENM, estão apresentadas na tabela 43.

Tabela 43. Mudanças provenientes do tratamento com a EENM.

\begin{tabular}{|c|c|c|c|}
\hline \multicolumn{4}{|c|}{ GRUPO 1} \\
\hline MUDANÇA & CONTEÚDO & $\mathbf{P}$ & $\mathbf{F}$ \\
\hline \multirow{10}{*}{ 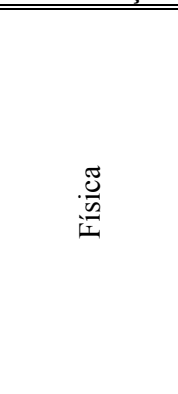 } & fortalecimento muscular & $1,2,5$ & 03 \\
\hline & aumento da sensibilidade & 1,3 & 02 \\
\hline & $\begin{array}{l}\text { manutenção da massa corporal } \\
\text { (melhora na estrutura física) }\end{array}$ & 4 & 01 \\
\hline & aparecimento de movimentos involuntários & 6 & 01 \\
\hline & aumento da irrigação sanguínea & 2 & 01 \\
\hline & diminuição da espasticidade & 6 & 01 \\
\hline & prevenção de osteoporose & 4 & 01 \\
\hline & ganho de equilíbrio corporal & 6 & 01 \\
\hline & inexistência de efeitos físicos & 5 & 01 \\
\hline & & Subtotal & 12 \\
\hline \multirow{6}{*}{ 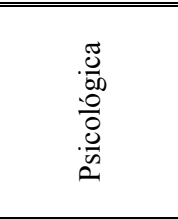 } & aumento da auto-estima & $1,5,6$ & 03 \\
\hline & aumento da auto-confiança & 1,3 & 02 \\
\hline & esperança na recuperação da marcha & 3,4 & 02 \\
\hline & perspectiva mais otimista para o futuro & 2 & 01 \\
\hline & maiores conhecimentos & 5 & 01 \\
\hline & & Subtotal & 09 \\
\hline \multirow{2}{*}{ Social } & socialização (troca de experiências) & $2,3,4,6$ & 04 \\
\hline & & Subtotal & 04 \\
\hline \multicolumn{4}{|c|}{ Total } \\
\hline \multicolumn{4}{|c|}{ GRUPO 2} \\
\hline MUDANÇA & CONTEÚDO & $\mathbf{P}$ & $\mathbf{F}$ \\
\hline \multirow{9}{*}{$\frac{\tilde{U}}{\frac{0}{n}}$} & " aumento da sensibilidade & $7,9,10,12$ & 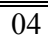 \\
\hline & fortalecimento muscular & 8,9 & 02 \\
\hline & aparecimento de movimentos involuntários & 8,10 & 02 \\
\hline & $\begin{array}{c}\text { manutenção da massa corporal } \\
\text { (melhora na estrutura física) }\end{array}$ & 8 & 01 \\
\hline & aumento da irrigação sanguínea & 12 & 01 \\
\hline & diminuição da espasticidade & 11 & 01 \\
\hline & melhorias na função sexual & 12 & 01 \\
\hline & aparecimento de movimentos voluntários & 9 & 01 \\
\hline & & Subtotal & 13 \\
\hline \multirow{3}{*}{ Psicológica } & perspectiva mais otimista para o futuro & 6,8 & 02 \\
\hline & aumento da auto-estima & 11 & 01 \\
\hline & & Subtotal & 03 \\
\hline \multirow{2}{*}{ Social } & "ambiente social mais restrito (mudança de cidade) & 9 & 01 \\
\hline & & Subtotal & 01 \\
\hline & & Total & 17 \\
\hline
\end{tabular}


Observando a tabela 43 , pode-se constatar algumas mudanças bastante significativas nos aspectos físicos, psicológicos e sociais, tanto no que se refere ao grupo 1 quanto ao grupo 2 . Predominam nos dois grupos, embora com um relato a mais no grupo 2, as modificações no aspecto físico, como àquelas que se referem ao fortalecimento muscular, aumento da sensibilidade, aparecimento de movimentos involuntários, manutenção da massa corporal, alterações na circulação sanguínea, diminuição da espasticidade, prevenção de osteoporose e ganho de equilíbrio corporal. As duas últimas apenas presentes no grupo 1. Em contrapartida, o aparecimento de movimentos voluntários é um efeito citado apenas no grupo 2, por um dos entrevistados, o que revela ser um efeito previsível, porém, não tão comum a pessoas acometidas por uma lesão medular que se submetem a EENM. Todos os efeitos citados no entanto, foram também observados por Cliquet $(1988,2003)$. Outro aspecto que chama a atenção e podendo ser observado somente no grupo 2 é o referente as melhorias na função sexual, citada por um dos entrevistados.

Observou-se, ainda, que o fortalecimento dos músculos localizados nas extremidades superiores e inferiores (pernas e braços) é relatado com mais freqüência no grupo 1, enquanto que no grupo 2, a mudança citada com maior freqüência diz respeito ao aumento da sensibilidade, o que vem mostrar que esta última ocorre anteriormente à primeira. Elas podem ser exemplificadas no seguinte depoimento:

Pessoa 1: Vai deixando você mais ágil. A sensação é que você tem mais força na perna, você ta fazendo uma transferência, alguma coisa, você não precisa ficar pensando na perna, ela vai ajudando, parece que você vai sentindo mais a perna.

A estimulação, como no depoimento de P1, é responsável por facilitar o exercício de alguns movimentos que, a partir de então, são realizados de maneira mais natural. Pode-se dizer, portanto, que este fator aponta para uma maior autonomia nas atividades de vida diária. As facilidades na realização do movimento, entretanto, não se constituem como uma ocorrência comum entre todos os entrevistados, a partir do uso de EENM, como pode ser ilustrado no seguinte depoimento: 
Pessoa 5: Mas em termo de ganho físico, de movimento de perna nada. Continua da mesma forma.

No relato de P5, observa-se a inexistência de mudanças físicas com a utilização de EENM. Faz-se importante destacar, entretanto, que este indivíduo encontra-se em uma condição física diferenciada em relação aos outros entrevistados, no que diz respeito ao nível de lesão. Ele possui uma lesão na região lombar, o que caracteriza seu quadro específico como menos promissor para uma possível reabilitação por meio da EENM. Isto ocorre devido à possibilidade de suas inervações periféricas estarem prejudicadas ou terem sofrido algum dano a sua integridade, ocasionado pela lesão medular.

Vale ressaltar que a prevenção de osteoporose, citada apenas no relato de um entrevistado do grupo 1, constitui-se em uma informação que lhes foi passada por algum profissional da saúde.

No aspecto psicológico, a EENM é percebida como responsável por mudanças que se refletem, na sua maioria, em pessoas do grupo 1, do qual possui um maior tempo de reabilitação através da EENM. No grupo 2, estas mudanças aparecem em menor número de relatos e abrangendo, principalmente, uma perspectiva mais otimista para o futuro. $\mathrm{O}$ aumento da auto-estima pode ser identificado em três dos relatos do grupo 1 e em um dos relatos do grupo 2, enquanto que o grupo 1 apresenta, também, outras mudanças no aspecto psicológico, como por exemplo o aumento da auto-confiança, esperança na recuperação da marcha e maiores conhecimentos sobre si e sobre seu corpo. Brow (1996), também detectou a presença de uma maior expectativa de recuperação, melhoras na auto-confiança e auto-estima, em pessoas que se utilizavam deste tratamento. Um fator que pode ter exercido uma grande influência nas diferenças de resultados entre os dois grupos, além do tempo de tratamento, diz respeito à situação na qual estas pessoas (participantes do grupo 2), encontravam-se neste programa (tabela 40), já que a sua maior parte, não realizava a marcha. 
Convém esclarecer, neste contexto, que a possibilidade de "ficar em pé" e o "andar" são bastante citados em seus relatos como algo estimulante e motivador, responsáveis por sentimentos que, embora sejam variados de acordo com cada pessoa, são considerados pelos que a realizam, como algo muito positivo e benéfico para suas vidas, de uma forma geral. Este fato pode ser exemplificado no relato abaixo:

Pessoa 6: Quem faz, sabe, a diferença. Faz um ano e meio que eu venho aqui, mais ou menos. Um ano e pouquinho... Um ano, que seja. O que já mudou, um ano em minha vida? Eu sei o quanto mudou. Talvez você não veja, mas eu sei. O equilíbrio muda, muda o modo de andar, muda o meu caminhar lá, porque é gostoso, é ótimo caminhar, muda, me dá uma forcinha a mais... Até na forma de eu me perceber... tô mudando a minha vida meu.

A possibilidade proporcionada pelo Programa de EENM de um maior contato social com outras pessoas acometidas por uma lesão medular é uma das questões ressaltadas nos relatos do grupo 1. Este contato é considerado, por estes entrevistados, como um fator muito importante tanto para suas vidas de uma forma geral, para o estabelecimento de trocas de experiências, como para o alcance de sua reabilitação como um todo. Tudo isto pode ser percebido em algumas de suas falas:

Pessoa 6: eu pude estar em contato com pessoas que estão com o mesmo detalhe, com a mesma deficiência... isso é bom porque eu sei que eu posso trazer algo pra alguém que precisa ouvir. Tem o mesmo problema, tem condições de vida diferentes, com o mesmo problema.

Pessoa 2: e também a parte de amizades que você faz aqui com as pessoas, então você se sente motivada em vir, fica contente em rever àquela pessoa, você acaba sendo amigo dela naquele momento, passa algum conflito, alguma informação e isso ajuda.

Os contatos sociais proporcionados pela EENM podem ser considerados terapêuticos, a partir do momento que funcionam como incentivadores na continuação e assiduidade ao tratamento, como facilitadores na troca de informações entre os próprios pacientes, como 
auxílio para a superação de conflitos e como estímulo para um enfrentamento adequado das suas dificuldades. Não obstante, foi mencionado por apenas um entrevistado do grupo 2 e encontrando-se vinculada, neste caso, a mudança de ambiente social empreendida por esta pessoa, no momento em que teve que mudar de cidade com o intuito de realizar o tratamento por meio da EENM. Tal mudança social reflete uma conotação negativa, assumindo um caráter restritivo e não ampliador. Seu relato pode ser visualizado, a seguir:

Pessoa 9: Mudança da minha cidade pra cá, da minha vida, porque eu fico engaiolada aqui, mas eu acho que se eu tenho um objetivo eu tenho que aprender a superar tudo. Porque a minha vida aqui é diferente da minha vida de lá. Aqui eu me sinto assim, muito presa, e lá não, lá eu vivia na rua com a minha mãe, lá eu tinha liberdade, a casa é grande entendeu? Eu tenho mais convívio com pessoas, aqui não. É uma vida bem prisioneira.

A partir da identificação de todas essas modificações advindas do tratamento com a EENM, torna-se muito importante compreender se todas estas alterações encontram-se relacionadas com as expectativas que estas pessoas possuem em relação a este tipo de tratamento. Entende-se que as expectativas existentes sobre qualquer tipo de intervenção reabilitacional podem se tornar muito relevantes na compreensão que a pessoa com lesão medular possui de seus resultados. O que elas buscavam ao iniciar o tratamento reabilitacional com a EENM e o quanto estas expectativas foram se modificando com o decorrer do tempo a que estavam submetidas a esta intervenção, também foram discutidos no contexto desta pesquisa. As mudanças nas expectativas em relação ao tratamento podem ocorrer com maior ou menor freqüência e podem ser justificadas como advindas de uma percepção mais realística sobre este tipo de reabilitação ou podem estar relacionadas com a observação de seus efeitos como valorativamente positivos ou negativos.

Por todos estes motivos, as expectativas iniciais e atuais dos entrevistados quanto a EENM, encontram-se destacadas na tabela 44. 
Tabela 44. Expectativas iniciais e atuais dos entrevistados quanto a reabilitação por meio da EENM

\begin{tabular}{|c|c|c|c|c|c|c|}
\hline \multicolumn{7}{|c|}{ GRUPO 1} \\
\hline 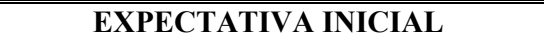 & $\bar{P}$ & $\overline{\mathbf{F}}$ & \multicolumn{2}{|c|}{ EXPECTATIVA ATUAL } & $\overline{\mathbf{P}}$ & $\bar{F}$ \\
\hline \multirow[t]{2}{*}{$\begin{array}{c}\text { restabelecimento total dos movimentos } \\
\text { (sem a utilização de aparelhos) Ex: "sair } \\
\text { andando" (P4, P2) }\end{array}$} & \multirow[t]{2}{*}{$2,4,5,6$} & \multirow[t]{2}{*}{04} & \multicolumn{2}{|c|}{$\begin{array}{c}\text { restabelecimento total dos } \\
\text { movimentos (sem a utilização de } \\
\text { aparelhos) }\end{array}$} & $1,2,3,4,5,6$ & 06 \\
\hline & & & & & & \\
\hline \multirow[t]{3}{*}{ não havia alguma expectativa } & \multirow[t]{2}{*}{1,3} & \multirow[t]{2}{*}{02} & \multirow{3}{*}{ melhorias físicas } & sensibilidade & 1,2 & 02 \\
\hline & & & & circulação & 1 & 01 \\
\hline & 5 & 01 & & & Subtotal & 03 \\
\hline & \multirow{3}{*}{\multicolumn{2}{|c|}{ Total }} & \multirow{3}{*}{\multicolumn{2}{|c|}{ recuperação funcional }} & 1,2 & 02 \\
\hline & & & & & Subtotal & 02 \\
\hline & & & & & Total & 111 \\
\hline \multicolumn{7}{|c|}{ GRUPO 2} \\
\hline EXPECTATIVA INICIAL & $\mathbf{P}$ & $\overline{\mathbf{F}}$ & \multicolumn{2}{|c|}{ EXPECTATIVA ATUAL } & $\mathbf{P}$ & $\mathbf{F}$ \\
\hline não havia alguma expectativa & $8,9,10$ & 03 & \multicolumn{2}{|c|}{$\begin{array}{l}\text { restabelecimento parcial dos } \\
\text { movimentos }\end{array}$} & $7,8,11$ & 03 \\
\hline $\begin{array}{l}\text { Restabelecimento dos movimentos (com } \\
\text { ou sem a ajuda de equipamentos de auxílio } \\
\text { ou aparelhos) }\end{array}$ & 7,11 & 02 & \multirow{2}{*}{\multicolumn{2}{|c|}{$\begin{array}{c}\text { restabelecimento total dos } \\
\text { movimentos (sem a utilização de } \\
\text { aparelhos) } \\
\text { melhorias na sua qualidade de } \\
\text { vida }\end{array}$}} & 10,12 & 02 \\
\hline $\begin{array}{l}\text { melhorias de uma forma geral (qualidade } \\
\text { de vida) }\end{array}$ & 12 & 01 & & & 10,12 & 02 \\
\hline & \multirow{2}{*}{ Total } & \multirow{2}{*}{06} & \multirow{2}{*}{\multicolumn{2}{|c|}{ não possui expectativas }} & 9 & 01 \\
\hline & & & & & Total & 08 \\
\hline
\end{tabular}

Com base nos depoimentos dos entrevistados apresentados na tabela 44, pode-se constatar que a maior parte dos integrantes do grupo 1 iniciou o tratamento com a esperança de que a EENM iria restabelecer todos os seus movimentos, inclusive o "andar" sem a ajuda de aparelhos ou utensílios ortopédicos. Já em relação ao grupo 2, observou-se, para a maior parte dos entrevistados, a inexistência de expectativas no primeiro momento. É importante notar neste contexto, que a inexistência de expectativas iniciais presentes nos relatos de P8, P9 e P10, coincidem com a falta de conhecimentos/concepções relativas à EENM apontada por estas pessoas, conforme indicam as tabelas 41 e 42 . Estas expectativas iniciais dos grupos 1 e 2, podem ser contempladas nos seguintes depoimentos:

Pessoa 2: Ah, sair andando. Todo mundo pensa nisso né? Essa é a expectativa. Em qualquer tratamento que você fica sabendo, seja até uma cirurgia ou até uma cirurgia espírita... Você fala: ah, eu vou lá, vou fazer e vou sair andando. Até a fisioterapia né? Então você fica naquela expectativa.

Pessoa 8: Eu não esperava nada porque eu não sabia o que acontecia, o que ia fazer a gente melhorar... 
Os depoimentos de P2 e P8 mostram a total falta de conhecimentos sobre este e outros tratamentos, no momento em que estas pessoas iniciam o seu processo reabilitacional, seja por meio da EENM ou mesmo, como citado por P2, o tratamento físioterápico.

Foi observada a ocorrência de alterações ou de uma total modificação das expectativas iniciais com o decorrer do tratamento. Destaca-se um aumento destas expectativas, de uma forma geral, tanto no grupo 1, quanto no grupo 2, particularmente, no caso daqueles que não esperavam alcançar resultados com este tipo de tratamento.Estas modificações podem ser contempladas nos seguintes relatos:

Pessoa 1: Ah sim, cada dia você vai tendo mais expectativas, vai conhecendo pessoas que estão melhores que você, vai vendo que você é capaz de ta chegando também.E, além disso, ta ganhando outras coisas também. Não coisas grandes, coisas pequenas, mas tá ganhando. Sensibilidade, circulação... já ta melhorando bastante.

Pessoa 3: Com o tempo ela mudou. Mudou a medida que eu... a primeira palestra que eu vim, que o professor Cliquet tava explicando, mostrando o caso que já teve antes que a pessoa, mesmo sem saber como, que ela passou a andar normalmente de novo... não criou aquela expectativa: não eu vou fazer igual a ele... daqui a pouco já vou ta andando, mas criou uma expectativa de que num futuro próximo posso não necessitar mais dessa estimulação e começar a andar mesmo a partir de mim. Porque na realidade o que ela faz é ensinar a você como você anda.

Observa-se que estas mudanças de expectativas encontram-se relacionadas, ora com a percepção de melhorias em si e em outros usuários do programa de EENM, ora como reflexo de uma compreensão referente à EENM, de que a mesma possibilitará a estas pessoas estar novamente em condições de exercer os movimentos que lhes foram subtraídos, devido à ocorrência da lesão medular, seja totalmente (grupo 1) ou parcialmente (grupo 2). É importante considerar, a partir da análise do relato da Pessoa 3, que esta mudança em suas expectativas encontra-se intimamente relacionada com a interpretação de 
informações adquiridas ao entrar e, também, durante a sua participação no programa de EENM.

Observou-se, também, que o aumento das expectativas apareceu na sua maior parte, relacionadas com as pessoas do grupo 1. Para estas pessoas, o tratamento através da EENM, será capaz de restabelecer totalmente os seus movimentos, sem a ajuda de aparelhos ou equipamentos de auxílio. No entanto, suas expectativas tornaram-se mais realísticas, já que marcadas pela percepção de que este tipo de reabilitação está baseado em uma suposição ou mesmo em resultados visíveis, entretanto, eles não podem ser garantidos ou alcançados de forma imediata. Tal modificação, na percepção dos efeitos da EENM, não traz entretanto, uma mudança quanto as expectativas de restabelecimento total dos movimentos. Considerando tratar-se de uma pesquisa, na qual não se pode afirmar com total clareza quais benefícios serão adquiridos por esta ou aquela pessoa, esta concepção realística do tratamento torna-se um fator imprescindível para que estas pessoas possam alcançar uma maior estabilidade emocional que, por sua vez, estará contribuindo significativamente para o êxito de seu processo reabilitacional (BRADLEY, 1994).Os relatos abaixo ilustram esta percepção mais realística sobre os efeitos da EENM:

Pessoa 5: Sair da cadeira de rodas, eu sei que hoje é uma coisa muito mais demorada e de repente, dependendo da tecnologia, do avanço da medicina e com o avanço exato a gente deixa a cadeira de rodas.

Pessoa 4: mas depois com conversa, das pessoas que participam, você passa esse primeiro impacto e vê que não vai sair andando assim de cara. E aí você vai aprendendo a conviver também, ajuda a conviver com o seu problema.

Esta nova forma de compreender a EENM traz a possibilidade de estar percebendo outros efeitos possíveis de serem obtidos com esta intervenção, que não o "andar" que, por sua vez, mostraram-se ter, também, um valor significativo tanto para as pessoas do grupo 1, quanto para as do grupo 2. Embora o grupo 2, não se refira diretamente às melhorias físicas e funcionais (já destacadas em relatos anteriores, nas tabelas 42 e 43), eles chamam a 
atenção para as melhorias gerais, refletidas de alguma forma em sua qualidade de vida, como pode ser destacado no seguinte relato:

Pessoa 10: Eu espero melhorar né. Sei lá, voltar a ter tranquilidade...

O enfoque dado à persistência do tratamento reflete a percepção de que o mesmo pode ser eficaz, desde que seja realizado com uma certa freqüência e disciplina. Esta concepção está baseada na compreensão de que o êxito com o tratamento através da EENM se estabelece a partir de um processo gradual e contínuo, além de estar determinado, em grande parte, pelo esforço empreendido pelas pessoas que se utilizam do mesmo. Esta percepção é visível nos depoimentos abaixo:

Pessoa 4: Mas agora eu compreendo que vai demorar, que por enquanto é uma pesquisa, eu sei disso e que eu também preciso me ajudar né? Que não é só aqui, que você pode tá trabalhando, fazendo outras coisas, como eu tô fazendo né? Eu tô fazendo tratamento com o Dr. T. ${ }^{8}$, que de repente tá me ajudando também a superar esse momento demorado que é cansativo.

Cabe destacar, neste relato, a percepção de que sua reabilitação não se encontra restrita ao tratamento com a EENM mas, ao contrário, torna-se importante que esteja sempre buscando novos tratamentos e, também, suas realizações pessoais, de uma forma geral.

As expectativas atuais encontradas nesta pesquisa, embora de formas diferenciadas, parecem se direcionar, de uma forma geral, para a recuperação total ou parcial dos movimentos e, mais especificamente, para o retorno da possibilidade de "ficar em pé" e “andar". Tal possibilidade já pode ser realizada com a ajuda dos aparelhos e a esperança quanto a alcançar a capacidade de andar sem aparelhos se constitui como uma expectativa importante para esta população.

\footnotetext{
${ }^{8}$ Pesquisa realizada na Faculdade de Medicina da USP, visando a recuperação de pacientes lesados medulares através da implantação de células-tronco na medula de pessoas lesionadas.
} 
Em apenas um dos relatos, relativo a uma pessoa do grupo 2 (P9), revelou-se a inexistência de expectativas atuais quanto a reabilitação por meio da EENM. Este relato baseia-se na idéia de que (para esta pessoa), a existência de qualquer expectativa poderia estar prejudicando a sua reabilitação, devido à ansiedade trazida pela mesma. Seu depoimento é evidenciado, a seguir:

Pessoa 9: Mas eu sou assim, eu vou fazendo e vou observando, mas sem criar expectativa pra uma decepção futura entendeu? Eu continuo pensando assim.

A maneira como estas pessoas avaliam este programa de EENM é uma análise bastante pertinente a esta pesquisa, no sentido de identificar as repercussões deste programa, na sua forma de funcionamento e o que, na concepção de seus usuários, deveria estar sendo modificado ou mantido. A opinião destas pessoas possui um valor inestimável, já que a partir destes depoimentos é possível obter informações que funcionem como base para a realização de um tratamento mais eficaz. Com base neste ponto de vista, os entrevistados foram questionados sobre as mudanças que, de acordo com eles, seriam necessárias para o aperfeiçoamento do programa. Suas respostas estão explicitadas na tabela 45 .

Os depoimentos sobre os problemas inerentes a este programa se dividem em dificuldades relacionadas com o funcionamento (13 relatos) e abrangência do programa (10 relatos). Observou-se que tais problemas apareceram com maior freqüência no grupo 1. Para este grupo, o funcionamento do programa é enfatizado e a organização dos atendimentos faziase prioritária, entre as mudanças necessárias. Nos depoimentos abaixo, esta percepção pode ser visualizada:

Pessoa 4: Organização. No começo era meio difícil, era muito mal organizado, você chegava aqui oito horas, sete e meia, você saia meio dia, uma hora. Agora melhorou bastante né? Cada um tem o seu horário, mas ainda tá pecando um pouco na organização.

Pessoa 6: Talvez esse negócio de horário, mas esse negócio de horário não vai dar certo. Não, porque eu venho de Campinas, o outro vem lá de Florianópolis, outro lá de São 
Paulo, outro mora aqui do lado, outro mora lá... não dá! Então não dá esse negócio de horário. Mas fora isso...

Tabela 45. Mudanças necessárias para o aperfeiçoamento do Programa de EENM, na opinião dos entrevistados.

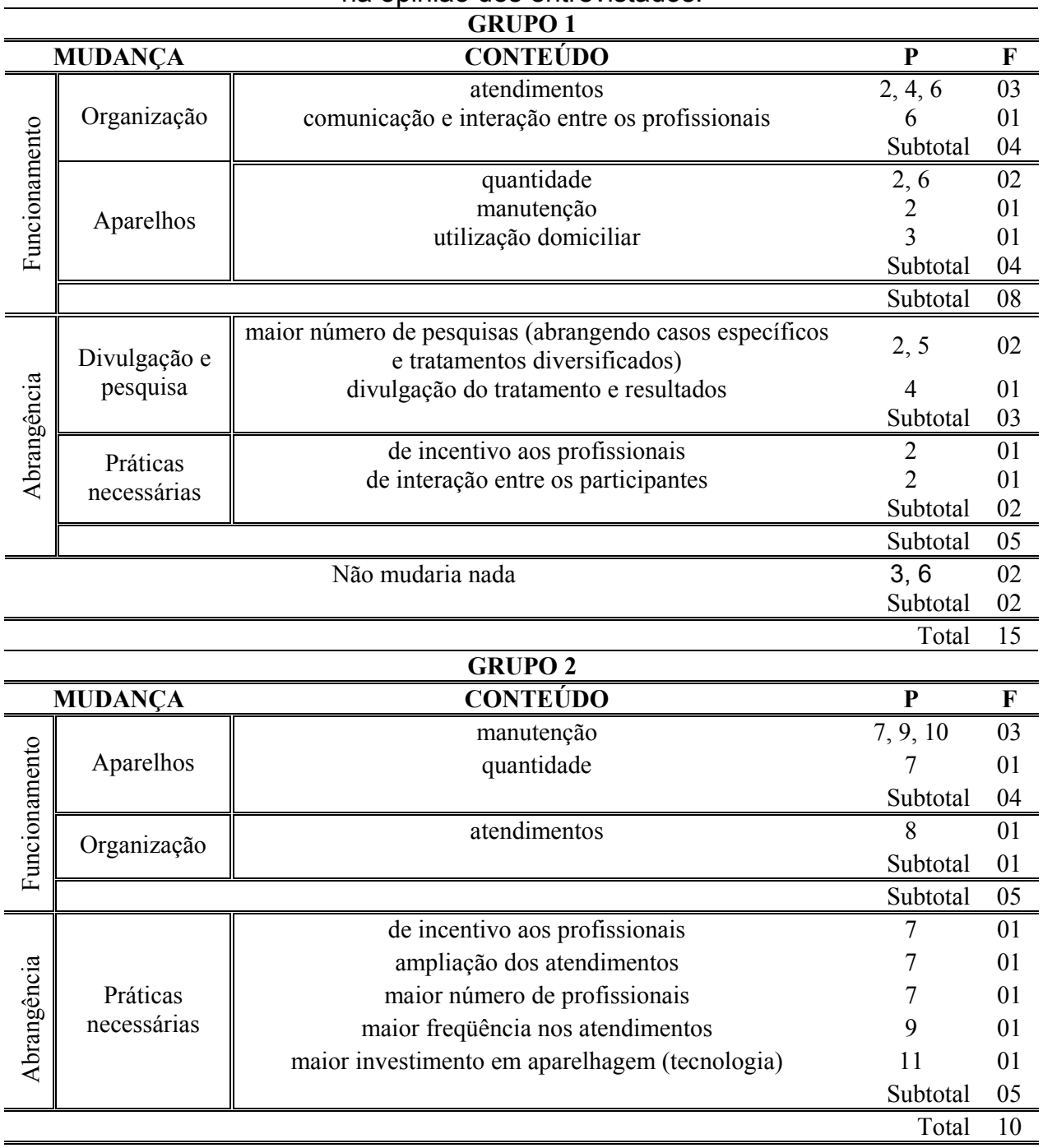

Levando-se em consideração o depoimento acima, faz-se necessária uma melhor organização dos horários de atendimento, embora seja perceptível para esta pessoa todas as dificuldades envolvidas neste procedimento. Outras dificuldades citadas com uma certa freqüência pelo grupo 1, e com mais evidência no grupo 2, em relação ao funcionamento, apontam para as condições dos aparelhos de estimulação. Mudanças na quantidade e manutenção dos aparelhos, de acordo com esta população, facilitariam o tratamento e o tornaria mais prático e viável para seus participantes. Em alguns casos, estas problemáticas 
encontram-se interligadas, de modo que as dificuldades observadas na organização dos atendimentos podem ser compreendidas como uma decorrência da grande e diversificada demanda encontrada para este tipo de tratamento e, também, devido à precariedade dos aparelhos que não conseguem suprir esta contingência. Tais afirmações relativas aos reparos que esta população acredita serem necessários ao funcionamento do programa de EENM, estão devidamente contempladas nos relatos abaixo:

Pessoa 6: Precisa só, detalhe. Ou aumentar os aparelhos. Não sei se tem aparelho suficiente, ou comprar mais baterias, não sei se não tem poder aquisitivo, ou se não tem as baterias... porque quando a gente chega não tem bateria, ou queima a bateria e não dá pra estimular. Então tá difícil! Se pudesse mudar a gente agradeceria. Você chega tem dez aparelhos, mas tem cinco funcionando... porque não tem bateria, o outro não tem não sei o $q u \hat{e} .$.

Pessoa 2: Eu ainda acho que é bem demorado o atendimento. Mas isso é devido a ter muitas pessoas, o aparelho às vezes quebra, não tem bateria...

No que se refere a abrangência, pode-se destacar, nos depoimentos do grupo 1, a solicitação de pesquisas referentes à casos mais específicos, como também, a implantação de outras formas de tratamento que ainda encontram-se em fase de pesquisa (2 relatos), além de maior divulgação do tratamento (1 relato). Os relatos seguintes ilustram estas necessidades:

Pessoa 5: Eu não sou apto a dizer pra mudar, mas eu gostaria, no meu caso por exemplo, que a minha perna não distende, mas ela encolhe, eu gostaria que eles tivessem uma pesquisa referente a isso. Porque que a minha perna encolhe e não distende, já que tá sendo estimulado o quadríceps? Então oque que eles podem fazer diferente pra poder minha perna distender? Com o estímulo elétrico? Então isso é o que eu gostaria que eles pudessem fazer!

Pessoa 2: A única coisa que falta é divulgar mais, colocar tipo cartazes mostrando, olha aconteceu isso... 
A necessidade de implantação de práticas de intervenção é destacada, principalmente, pelas pessoas do grupo 2 e se referem a um maior incentivo dos profissionais envolvidos no programa, ampliação dos atendimentos, maior número de profissionais, maior freqüência nos atendimentos e maior investimento em aparelhagem (tecnologia), ocorrendo um relato para cada uma destas respostas.

Vale ressaltar ainda, a ocorrência de 2 respostas, referentes aos participantes do grupo 1, relatando não serem necessárias mudanças no referido programa.

Os pontos positivos do programa também foram ressaltados, pelos entrevistados, e encontram-se contemplados na tabela 46.

Tabela 46. Aspectos positivos do Programa de EENM, na opinião dos entrevistados.

\begin{tabular}{|c|c|c|c|c|}
\hline \multicolumn{5}{|c|}{ GRUPO 1} \\
\hline \multicolumn{3}{|c|}{ ASPECTOS POSITIVOS } & $\overline{\mathbf{P}}$ & $\mathbf{F}$ \\
\hline \multirow{8}{*}{ 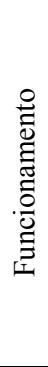 } & \multirow{2}{*}{ Atendimento } & "interesse, dedicação e atuação dos & $3,5,6$ & 03 \\
\hline & & & Subtotal & 03 \\
\hline & \multirow{2}{*}{ Localização } & espaço adequado & $1,2,5$ & 03 \\
\hline & & & Subtotal & 03 \\
\hline & \multirow{3}{*}{ Organização } & interação entre os profissionais & 4 & 01 \\
\hline & & dos atendimentos & 1 & 01 \\
\hline & & & Subtotal & 02 \\
\hline & & & Subtotal & 08 \\
\hline \multirow{5}{*}{ 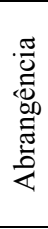 } & \multirow{2}{*}{ Pesquisa } & investimento em maiores & 2 & 01 \\
\hline & & & Subtotal & 01 \\
\hline & \multirow{2}{*}{\begin{tabular}{|c|} 
Aparelhagem \\
(tecnologia)
\end{tabular}} & aparelhos de auxílio implantados & 5 & 01 \\
\hline & & & Subtotal & 01 \\
\hline & & & Subtotal & 02 \\
\hline & & & Total & 10 \\
\hline \multicolumn{5}{|c|}{ GRUPO 2} \\
\hline \multicolumn{3}{|c|}{ ASPECTOS POSITIVOS } & 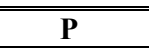 & $\overline{\mathbf{F}}$ \\
\hline \multirow{2}{*}{\multicolumn{2}{|c|}{$\begin{array}{c}\text { Funcionamento - } \\
\text { Atendimento }\end{array}$}} & Interesse, dedicação e atuação dos & $10,11,12$ & 03 \\
\hline & & & Subtotal & 03 \\
\hline \multirow{2}{*}{\multicolumn{2}{|c|}{ Abrangência }} & tecnologia (tratamento) & 7 & 01 \\
\hline & & & Subtotal & 01 \\
\hline & & & Total & 04 \\
\hline
\end{tabular}

De acordo com a tabela 46, os aspectos positivos do Programa de EENM encontram-se concentrados em seu funcionamento, tanto no grupo1 quanto no grupo 2. Principalmente, 
no que diz respeito ao atendimento prestado pelos profissionais envolvidos neste programa. O espaço em que o mesmo é realizado, também, é avaliado de forma positiva pelos participantes do grupo 1 .

Embora os resultados apresentados na tabela 45, quanto as mudanças necessárias neste programa, também estejam se referindo ao seu funcionamento, observou-se um enfoque maior na manutenção dos aparelhos e na organização dos atendimentos. Esta última é considerada positiva em apenas um dos relatos, como pode ser contemplado na tabela 46.

O trabalho exercido pelos profissionais participantes do Programa de EENM é considerado pelos entrevistados como o seu principal aspecto positivo. Eles enfatizam esta questão nos relatos seguintes:

Pessoa 3: Eu não mudaria os profissionais. Eu sinto assim que eles têm muita vontade de ta acompanhando o paciente, de ta ajudando o paciente e ao mesmo tempo eles transmitem calma para os pacientes. Não é aquela coisa: não, vamos lá, você tem que fazer, você tem que ir, você tem... ta preparado? Vamos mais uma vez? Então eu acho que o essencial é os profissionais. Eu já fui em outros lugares, já vi tratamento, até na televisão, mesmo aonde eu trabalho, não há tantas pessoas com força de vontade como eu vejo aqui.

Pessoa 5: Eu acho que o tratamento das pessoas. A forma que eles tratam a gente aqui não deveria ser mudada. Acho que eles tratam a gente com muita humanidade, com muita sinceridade. Você não vê as pessoas te tratarem com má vontade. Elas sempre vêm te atender naquele intuito de querer te ajudar o máximo que puder. Ninguém faz corpo mole aqui. Acho que todo mundo trabalha em prol da melhora... além do trabalho deles, do desenvolvimento do trabalho deles, mas na intenção que o deficiente fisico realmente fique curado daquilo ali. Então isso aí eu acho que eu não mudaria não. Eu acho que tá legal assim, porque as pessoas têm um coração muito grande, eu acho legal. 
Eles também percebem um interesse advindo desta equipe em estar sempre procurando renovar os seus conhecimentos e habilidades profissionais, como pode ser percebido no seguinte relato:

Pessoa 2: Eu acho que estão crescendo né? Estão aprendendo junto com a gente, porque a medula também é uma coisa que não se tem muito conhecimento de como ela vai te responder. Então eles tão seguindo o caminho certo e a cada dia eles vão aperfeiçoando isso. Se tratando de UNICAMP é um dos hospitais mais importantes que se tem, que todo mundo conhece, é uma coisa revolucionária...

A partir do depoimento de $\mathrm{P} 2$, percebe-se uma consciência de que a reabilitação com a EENM é uma intervenção baseada nos últimos avanços tecnológicos existentes sendo, portanto, considerado um tratamento de ultima geração. Por todos estes motivos, a EENM começou a ser realizada no Brasil com o objetivo de atender pessoas com lesão medular, recentemente. No que diz respeito ao espaço destinado ao tratamento através da EENM, faz-se importante assinalar que, somente há muito pouco tempo, esta intervenção começou a ser realizada em um espaço considerado adequado para atender aos portadores de lesão medular. A conquista deste espaço e sua adequação também são discutidas em seus relatos, como algo que trouxe grandes benefícios para este programa, em específico. Pode-se constatar esta consideração na fala que se segue:

Pessoa 2: mas eu acho que com esse local aqui já teve um grande progresso, é um local gostoso, tem bastante espaço, então eu acho que eles tão indo pro caminho certo, né?

A existência de aparelhos que proporcionem novas formas de intervenção e os investimentos em pesquisas (grupo 1), além do enfoque à própria tecnologia (grupo 2), também aparecem em seus relatos, com uma resposta cada um. Ressaltando-se, neste contexto, a predominância de respostas encontradas no grupo 1, em relação aos aspectos positivos do programa de EENM. 
Os entrevistados também foram questionados no que se refere a sua percepção sobre a equipe multidisciplinar constituída para realizar este tratamento. Suas respostas podem ser visualizadas na tabela 47.

Tabela 47. Percepção dos entrevistados sobre a constituição da equipe multidisciplinar do Programa de EENM.

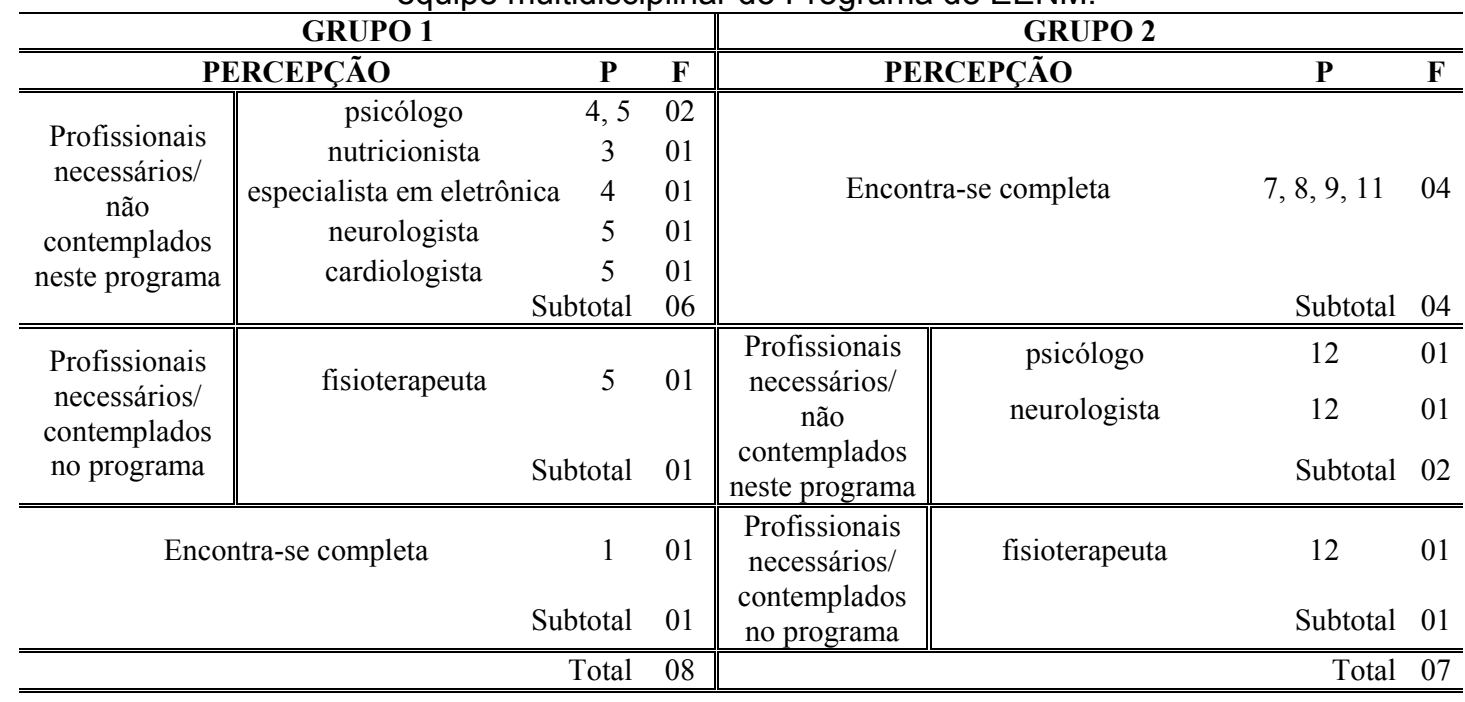

Como pode ser percebido na tabela 47, embora a EENM se constitua em um tratamento complexo e com repercussão em todos os âmbitos da vida destas pessoas, necessitando, portanto, de uma equipe multidisciplinar que envolva profissionais de áreas de conhecimento diversificadas, ainda são observadas algumas lacunas, no que diz respeito à constituição de sua equipe. Os entrevistados, especialmente os do grupo 1, citaram alguns profissionais que não fazem parte desta equipe e que percebem como essenciais para a obtenção de melhores resultados em seu processo reabilitacional, através da EENM. Para os dois grupos estes profissionais seriam, principalmente, psicólogos (3 relatos) e neurologistas (2 relatos). Outros profissionais citados somente pelo grupo 1, incluem nutricionistas (1 relato), especialistas em eletrônica e computação (1 relato) e cardiologistas (1 relato). A percepção da necessidade do profissional psicólogo encontra-se presente no depoimento abaixo:

Pessoa 5: a psicóloga também é fundamental né... tem sempre um problema emotivo na qual a pessoa pode ajudar. 
Em um outro relato, observa-se a existência de uma certa insegurança para apontar quais seriam os profissionais mais adequados a este tipo de tratamento, justificada por um desconhecimento sobre estes profissionais e sua importância neste contexto, como pode ser observado na fala da Pessoa 2:

Pessoa 2: Quanto a isso eu não sei, eu não tenho muitos conhecimentos de outros profissionais. Cada um ta na sua área né? Em relação a médicos eu não sei o que mudar... Antes não tinha psicólogo, agora tem, se você quer conversar...

É possível inferir, a partir deste depoimento (P2), a existência de uma reação positiva à inserção do psicólogo na equipe multidisciplinar do programa de EENM. Houve, igualmente, a afirmação da existência deste profissional na referida equipe (que seria a realizadora desta pesquisa), embora os entrevistados tenham sido informados sobre a sua inserção no programa como pesquisadora e, por um tempo determinado, que consistiria no tempo previsto para a realização e finalização desta pesquisa.

A consideração sobre a necessidade de fisioterapeutas pode ser explicada por um desconhecimento sobre a formação dos profissionais que constituem esta equipe, ou mesmo, baseada na percepção do trabalho exercido por esse profissional no tratamento com a EENM. Tal percepção aponta para uma vivência bem específica do trabalho realizado por este profissional que, por sua vez, não condiz com a prática deste especialista dentro do Programa de EENM.

De acordo com os relatos do grupo 2, em particular, a equipe de profissionais encontra-se completa, sem se que seja necessária a atuação de outros profissionais, que não os que já fazem parte desta equipe, como mencionado na fala abaixo:

Pessoa 13: Eu acho que já tá certo, completo.

As concepções dos entrevistados sobre a inserção do psicólogo na equipe multidisciplinar encontram-se apresentadas na tabela 48. 
Tabela 48. Concepções sobre a inserção do psicólogo no Programa de EENM.

\begin{tabular}{|c|c|c|c|c|}
\hline \multicolumn{5}{|c|}{ GRUPO 1} \\
\hline \multicolumn{2}{|c|}{ CONCEPÇÃO } & CONTEÚDO & $\mathbf{P}$ & $\mathbf{F}$ \\
\hline \multirow{7}{*}{ 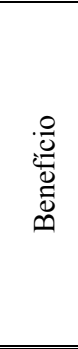 } & \multirow{3}{*}{ 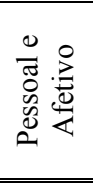 } & $\begin{array}{c}\text { acolhimento/possibilidade de uma escuta profissional } \\
\text { orientação em relação às suas expectativas, } \\
\text { sentimentos e atitudes }\end{array}$ & $\begin{array}{c}2,3,4,6 \\
1,3,4\end{array}$ & 04 \\
\hline & & auto-conhecimento & 1 & 01 \\
\hline & & & Subtotal & 08 \\
\hline & \multirow{3}{*}{$\begin{array}{l}\bar{\pi} \\
0 \\
0 \\
0\end{array}$} & \multirow{3}{*}{$\begin{array}{l}\text { maior interação social } \\
\text { melhorias nos relacionamentos sociais }\end{array}$} & 2 & 01 \\
\hline & & & 4 & 01 \\
\hline & & & Subtotal & 02 \\
\hline & & & Subtotal & 10 \\
\hline & & & Total & 10 \\
\hline \multicolumn{5}{|c|}{ GRUPO 2} \\
\hline \multicolumn{2}{|c|}{ CONCEPÇÃO } & CONTEÚDO & $\mathbf{P}$ & $\mathbf{F}$ \\
\hline \multirow{4}{*}{ 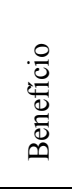 } & \multirow{4}{*}{ 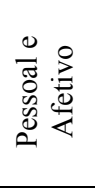 } & acolhimento/possibilidade de uma escuta profissional & $7,9,10$ & 03 \\
\hline & & $\begin{array}{c}\text { orientação em relação as suas expectativas, } \\
\text { sentimentos e atitudes }\end{array}$ & $1,3,4$ & 03 \\
\hline & & suporte afetivo & 8,12 & 02 \\
\hline & & & Subtotal & 08 \\
\hline & & & Total & 08 \\
\hline
\end{tabular}

Como pode ser vislumbrado na tabela 48 , as concepções relativas ao trabalho do psicólogo dentro do espaço de reabilitação por meio da EENM referem-se, exclusivamente, aos benefícios que podem ser trazidos pelo mesmo. Eles relatam, com maior ênfase (grupo $1 \mathrm{e}$ 2), os benefícios pessoais e afetivos, como a possibilidade de uma escuta profissional (7 relatos), uma maior orientação em relação às suas expectativas e administração de seus sentimentos, assim como de suas atitudes (6 relatos). No que tange ao grupo 1, os benefícios englobariam os aspectos pessoais/afetivos e sociais. Já para o grupo 2, tais benefícios estariam somente relacionados aos aspectos pessoais e afetivos.Observou-se a existência, no que se refere ao benefício pessoal e afetivo, de alguns ganhos com esta atuação, que diferenciam as falas das pessoas referentes ao grupo 1 e 2. Seriam elas: o auto-conhecimento, citado apenas por um entrevistado do grupo 1 e o suporte afetivo, relatado por duas pessoas pertencentes ao grupo 2 .

A possibilidade de estarem se beneficiando com uma escuta especializada pode ser, portanto, observada como uma concepção do papel do profissional psicólogo. Tal concepção é destacada no seguinte depoimento: 
Pessoa 4: E às vezes o paciente ele precisa ter uma pessoa pra conversar, pra extravasa algumas angustias que ele extravasa com seus familiares de forma diferente. Através de uma agressão... e de repente ele conversando com o psicólogo, o psicólogo vai tá orientando de forma diferente, a pessoa acaba se abrindo e essas angustias vão passar. E as pessoas vão entendendo que tem que viver um dia de cada vez, dar um passo de cada vez e não adianta você tentar sair correndo que você não vai conseguir.

O benefício social advindo da atuação do psicólogo, caracterizado pela realização de uma maior interação social e pelas melhorias nos relacionamentos sociais, é relatado apenas no grupo 1 e evidenciado em menor número de respostas (uma resposta cada).

O tipo de atuação que este profissional deve exercer, na opinião dos entrevistados, encontra-se explicitada na tabela 49.

Tabela 49. Tipo de atuação que o psicólogo deve exercer, na opinião dos entrevistados.

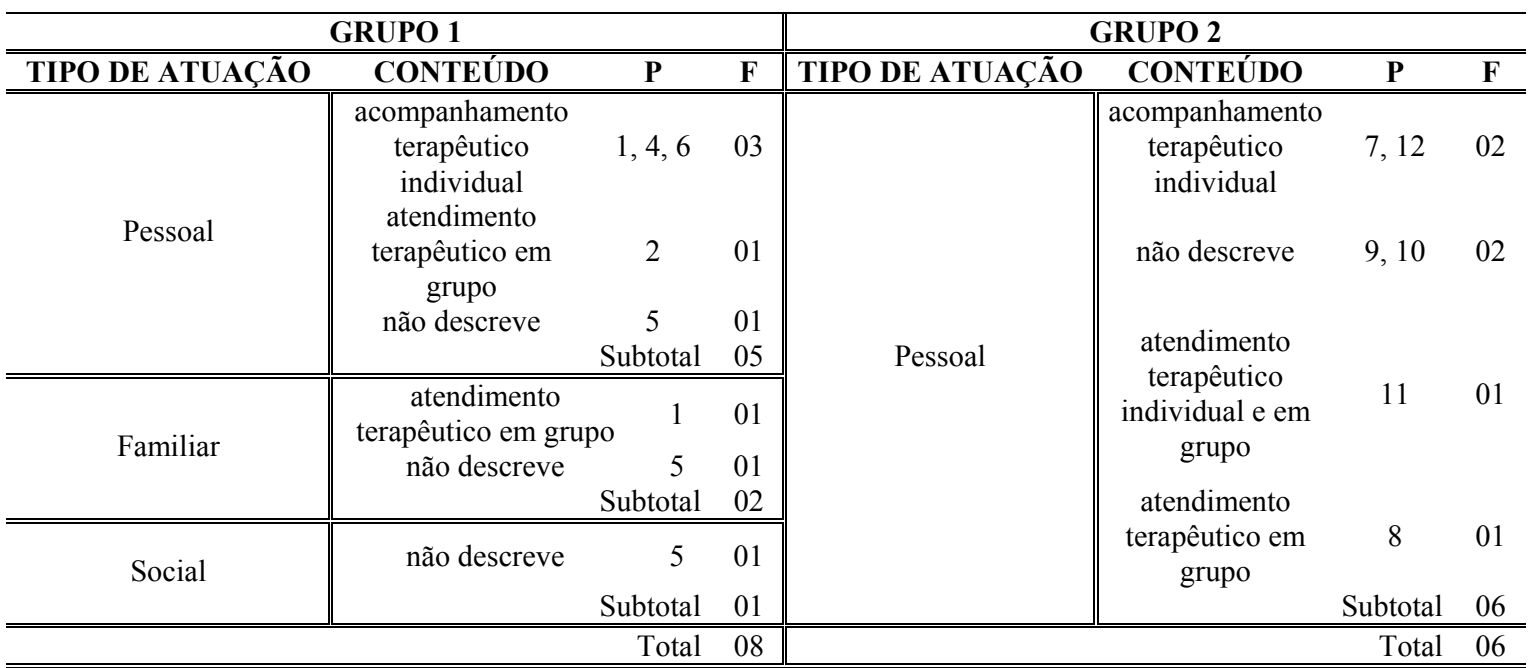

De acordo com seus relatos, já mencionados na tabela 48 e confirmados na tabela 49 , o psicólogo deve assumir função de suporte e de apoio emocional, provido de uma escuta analítica muito particular a este profissional, com maior ênfase a uma atuação que priorize um atendimento pessoal, focalizado portanto, na pessoa com lesão medular. No entanto, embora com menor freqüência, são citadas, no grupo 1, as atuações familiares e sociais, enquanto que no grupo 2, a atuação do psicólogo deve se restringir ao atendimento da 
pessoa com lesão medular (pessoal), com ênfase no atendimento individual. $\mathrm{O}$ atendimento em grupo destas pessoas é também focalizado pelo grupo 1 e 2 , podendo ocorrer de forma exclusiva ou paralela ao atendimento individual. A intervenção do psicólogo, assume portanto, uma gama enorme de procedimentos que podem ser considerados adequados a esta população. O discurso, abaixo, ilustra uma percepção destas questões:

Pessoa 1: Acho que seu trabalho deveria estar acompanhando, ver o que era antes e o que é agora, dificuldades, família que influencia muito, ta achando aquele ponto que ta fazendo mal, vamos dizer, que não ta deixando a pessoa progredir. Primeiro ao paciente, aí depois se você perceber que existe mais coisa atrás disso...se você vê que o negócio não é só com ele e que alguém não está agindo certo, alguma coisa desse tipo e ir buscar... o trabalho em grupo sim, é legal o trabalho em grupo com as familias. Acho que com o paciente seria mais individual.

O trabalho do psicólogo, direcionado à sociedade, de uma forma geral, foi citado em um dos relatos, entretanto, sem uma descrição que aponte para como tal atuação poderia estar sendo desenvolvida.

Os entrevistados relataram suas expectativas para o futuro. Elas encontram-se contempladas na tabela 50 .

Como pode ser observado na tabela 50, as expectativas dos entrevistados em relação ao futuro se diferenciam de acordo com o grupo a que se refere. As expectativas do grupo 1 se baseiam, principalmente, nos ganhos corporais, com uma predominância para a recuperação total de suas funções motoras, em especial, na possibilidade de "voltar a andar" sem a ajuda de aparelhos ou de equipamentos de auxílio, como muletas e órteses, coincidindo com as expectativas atuais em relação à reabilitação com a EENM (tabela 44). O relato, abaixo, confirma tal expectativa:

Pessoa 1: É voltar... se surgir a cura... é voltar a andar. É à medida que ta surgindo a cura é você ta legal, com nada que te impeça, fazendo fisioterapia você vai ta cada vez melhor e 
se o caminho é eletroterapia, puxa legal! Eu to nesse caminho e eu to melhorando. E se surgir alguma outra coisa também eu esteja pronto pra fazer.

Tabela 50. Expectativas para o futuro.

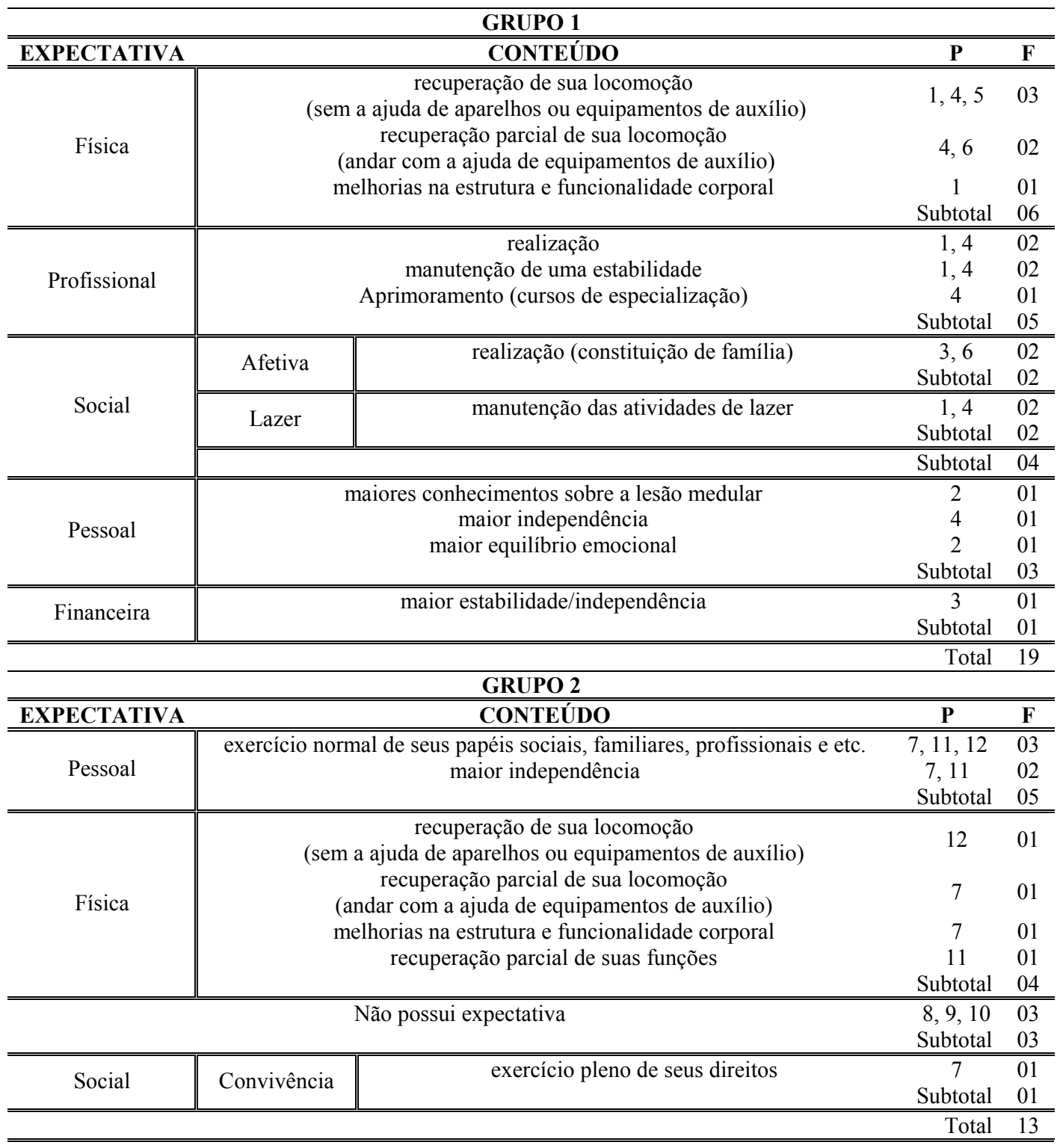

A tabela 50 aponta para um maior número de expectativas no que se refere às pessoas do grupo1. As que se mostraram comuns aos dois grupos são as de natureza pessoal, física e social, sendo que as expectativas relacionadas com o aspecto físico, apareceram com maior número de relatos no grupo 1 . Por sua vez, as expectativas do grupo 2 estão voltadas, na sua maior parte, para uma realização pessoal, pautadas principalmente, no exercício normal 
de seus papéis sociais, familiares, profissionais e etc..., além de uma maior independência de uma forma geral, podendo obter com isso, uma melhor qualidade de vida. Os participantes do grupo 1, também se referem ao aspecto profissional, como algo importante em suas expectativas para o futuro (5 relatos). $\mathrm{O}$ aspecto social é mais enfatizado pelas pessoas do grupo 1, se detendo nas realizações afetivas e manutenção das atividades de lazer (4 relatos). No grupo 2, o aspecto social aparece em um dos relatos com uma dimensão mais ampla, incluindo a conquista de seus direitos como cidadãos. A inexistência de expectativas em relação ao futuro aparece em três dos relatos apontados apenas pelo grupo 2. Ela encontra-se baseada na preocupação em viver plenamente cada instante de sua vida. O futuro, neste caso, irá aparecer como uma suposição, já que não existe uma certeza ou uma promessa concreta de um futuro determinado.Tal constatação é evidenciada no depoimento abaixo:

Pessoa 9: Eu não sou muito de planos. Depois desse acidente...eu tinha tantos planos... eu não sou muito de fazer planos, deixa acontecer...eu não faço plano nenhum. Vou vivendo de acordo com o dia dia...

Werner (1994) relata as incertezas quanto ao futuro trazidas por uma lesão medular. No entanto, os participantes desta pesquisa entendem que poderão continuar fazendo o que fazem normalmente e, ainda, alcançar algumas metas que hoje são desejos, como por exemplo, a recuperação dos movimentos que lhes foram subtraídos ou mesmo a melhora em sua qualidade de vida, de uma forma geral.

Presume-se que este futuro, inconstante e incerto, não os impede de continuarem lutando pelos seus objetivos. Por outro lado, observa-se que a vida no presente também é muito importante para estas pessoas, de forma que suas esperanças no futuro não as impedem de continuarem vivendo o seu presente, seja nos aspectos sociais, profissionais e afetivos. Outro aspecto bastante visível em relação às suas expectativas para o futuro, diz respeito à maneira otimista em que projetam o seu futuro. Este otimismo é claramente apontado no seguinte relato: 
Pessoa 6: Nossa! Meu futuro é brilhante! Minha vida, meu trabalho... Eu espero a minha felicidade. Eu avisto a minha felicidade meu, no amanhã. Minha felicidade é Deus que é o pai primeiramente, minha família e a minha esposa. Acabou! E o meu tratamento... Essa é a minha felicidade. Deus em cima, que ele tem o controle, à frente a minha família, aqui a minha esposa e aqui é o meu tratamento. E atrás o meu trabalho. Minha felicidade não está vinculada ao andar. De jeito nenhum. O meu andar é um detalhe! Um detalhe tão pequeno, mas tão pequeno, tão pequeno... Você quer andar? Quero, no entanto que eu torço por isso. Eu vivo a minha vida. Eu vivo cada segundo dela, cada segundo, cada detalhe, cada coisinha.

Deve-se chamar a atenção para o fato de que este otimismo em relação ao futuro, não se encontra, necessariamente, vinculado à recuperação dos seus movimentos ou da possibilidade de voltar a andar, como pode ser explicitado nos depoimentos que se seguem:

Pessoa 4: Muito deficiente físico acha que não vai voltar a andar. Então, eles são totalmente sem esperança. Não, não tem jeito, acabou. E acabam se tornando pessoas depressivas né, você vai conversar com a pessoa, a pessoa tá super pra baixo. Eu já encaro de forma diferente, eu não sei se eu tive acesso a algumas coisas a mais, né? Eu faço fisioterapia tá?Eu venho fazer eletro estimulação e to fazendo também um processo novo, um trabalho novo, que é as células tronco. Eu não sei se é porque eu tive acesso a isso daí... então eu acho que há uma possibilidade de voltar a andar. Mas também não descarto a possibilidade de ficar paraplégico e tento lidar com essa possibilidade também da melhor maneira possivel.

Pessoa 2: Hoje em dia eu tenho aquela esperança, mas eu não vou deixar àquela esperança e esquecer das coisas que eu posso fazer sentada. Se eu chegar nos setenta anos e voltar a andar, dai a gente pensa no que pode ser feito, senão eu vou olhar pra trás e falar: Olha, eu fui até o barzinho, até a lanchonete e chupei a sorvete na cadeirinha.

Subentende-se que os entrevistados possuam uma expectativa positiva em relação ao seu futuro, podendo significar otimismo ou aceitação realista - e não passiva - de sua nova 
condição. Também apresentam uma percepção do momento presente que se baseia em realizações pessoais, vocacionais, sociais e etc.

Este estudo possibilitou revelar, através dos relatos dos entrevistados e de seus familiares, aspectos de suas vivências, expectativas e percepções sobre si, além de apreender a forma como percebem e se relacionam no seu contexto familiar, reabilitacional, de trabalho e social. As considerações finais abordam aspectos significativos e relativos aos resultados apresentados, encontrando-se contempladas a seguir:

\section{Considerações Finais}

Buscando compreender como as pessoas com lesão medular submetidas a um programa de EENM e suas famílias, viveram todas as mudanças advindas da lesão medular e como se inserem profissional, social, afetiva e reabilitacionalmente, esta análise proporcionou uma ampla visão de como pensam e como vivem os participantes desta pesquisa, considerando as questões que os tornam um grupo relativamente diferenciado.

A começar pelas condições clínicas e fisiológicas dos entrevistados, vale destacar que sua maior parte (9) sofreu uma paraplegia, ocorrida devido a um traumatismo medular que afetou, em oito deles, a região torácica (Pessoas 1, 2, 3, 4, 6,7, 9 e 10) e, em um deles, a região lombar (Pessoa 5). Nestes casos, suas capacidades de movimentação e sensibilidade se encontram restritas à porção superior do corpo (cabeça, tórax, abdome e membros superiores) podendo obter mais ou menos flexibilidade nas suas condições físicas e fisiológicas, de acordo com o nível e grau de sua lesão. As lesões atingindo a região torácica abrangeram uma amplitude que variava entre a vértebra torácica de número quatro até a de número doze, alcançando, portanto, variadas manifestações clínicas. Estas manifestações, por sua vez, vão se estabelecer de acordo com a vértebra atingida, ou seja, quanto mais alta a lesão, menor a flexibilidade e movimentação. Na pessoa em que a lesão alcançou a vértebra torácica de número doze e primeira lombar (Pessoa 5), observa-se um quadro clínico mais favorável quanto a sua locomoção, entretanto, deduz-se a ocorrência de 
dificuldades em relação ao tratamento com a EENM, já que pode ocorrer um prejuízo de alguns nervos periféricos e que são necessários para que a estimulação elétrica possa alcançar uma contração muscular (BENTON et al., 1979). Os três entrevistados acometidos por uma lesão cervical, caracterizando portanto uma tetraplegia, possuem limitações para a movimentação e sensibilidade nas partes superiores e inferiores do corpo. Trata-se de lesões consideradas altas, atingindo as vértebras cervicais de números cinco, seis e sete.

A condição de gênero destas pessoas revelou que esta população é composta de nove homens (Pessoas 1, 3, 4, 5, 6, 8, 10, 11 e 12) e de três mulheres (Pessoas 2, 7 e 9), o que caracteriza este grupo como predominantemente masculino. No que diz respeito à idade, foi constatada a inclusão de idades que alcançavam vinte e dois a quarenta e quatro anos, o que indica tratar-se de uma população jovem, porém, dentro de uma faixa etária na qual nossa cultura exige uma estabilidade maior em relação aos aspectos profissionais, sociais, familiares ou afetivos.

Exceto as Pessoas 5, 6, 10 e 11 que se intitularam como evangélicas, a Pessoa 9 como espírita e a 12, que afirmou não seguir uma religião, todos os outros entrevistados tem como religião e prática religiosa o catolicismo, embora a Pessoa 1 não se considere praticante.

A crença religiosa encontra-se presente em seus depoimentos, parecendo atingir um maior fortalecimento quando é considerada responsável pela sobrevivência destas pessoas aos acidentes causadores da lesão medular, adquirindo menor valor quando relacionada com o fato de se tornarem deficientes, já que atribuído ao destino (concepção também fatalista), e sem alguma manifestação, quando se referem à ocorrência de melhorias funcionais. A contribuição de seus próprios esforços e de suas famílias é um aspecto ressaltado neste caso (concepção realista).

Outra questão proeminente se refere ao nível de escolaridade destas pessoas, podendo ser caracterizado entre médio e alto, a partir da consideração de que três deles possuem o 
ensino médio completo (Pessoas 3, 5 e 6), três tem o superior completo (Pessoas 2, 4 e 12) e dois deles não concluíram o ensino superior (Pessoas 1 e 9). Os outros quatro encontravam-se com o ensino médio incompleto (Pessoas 7 e 8 ) e ensino fundamental completo (Pessoa 11) ou incompleto (Pessoa 10).

Uma diferenciação bastante nítida entre esta população está na idade em que ocorreu a lesão. Para a Pessoa 2, a lesão medular significou uma ruptura estabelecida quando ainda era criança (aos nove anos de idade). No caso da Pessoa 3, a lesão medular instalou-se durante a sua adolescência, visto que se tornou deficiente físico aos quatorze anos. Já em relação às dez pessoas restantes, que equivalem à maioria, a lesão medular foi um acontecimento ocorrido durante a sua vida adulta, atingindo uma fase da vida considerada como período produtivo (entre 24 e 38 anos), o que confirma os dados apontados pela literatura.

Quanto ao tempo em que estas pessoas se encontram na condição de lesados medulares, é possível dividí-los em dois grupos distintos, a saber: os que se encontram lesionados entre 1 e 5 anos (Pessoas 1, 4, 6, 8, 10, 11 e 12), consistindo na sua maioria e, finalmente, aqueles que convivem com a lesão medular entre 10 e 16 anos (Pessoas 2, 3, 5, 7 e 9).

A instalação da lesão medular ocorreu em decorrência de situações diversificadas, que se caracterizaram, principalmente, como acidentes automobilísticos (Pessoas 2, 3, 4, 5, 7, 8 e 9), na sua grande maioria e, logo depois, acidentes com arma de fogo (Pessoa 1 e 6).

Quanto as percepções relacionadas à lesão medular, os entrevistados enfocam com maior freqüência, as modificações corporais. De acordo com Vash (1988), tal percepção associase a um enfoque culturalmente estabelecido, onde o aspecto físico é super valorizado. Sem dúvida, estas pessoas necessitam, a partir do momento em que se tornam deficientes físicos, estabelecer toda uma reestruturação em sua imagem e identidade corporal. As reações de tristeza, revolta, negação e crença em uma recuperação imediata de suas funções físicas, após a ocorrência da deficiência, mostra os efeitos emocionais provenientes de uma deficiência física como a lesão medular. 
Os entrevistados e suas famílias não possuíam conhecimentos anteriores sobre todas as conseqüências advindas de uma lesão medular. Tal desconhecimento é percebido em alguns momentos, como reflexo de um comportamento social marcado pela indiferença em relação às pessoas que possuem alguma deficiência. Estes fatos apontam para a necessidade de conscientização da população em relação a esta patologia, suas causas, efeitos e importância destas pessoas como "sujeitos sociais".

Os entrevistados buscavam lidar com as mudanças proporcionadas pela lesão medular, através de formas de enfrentamento caracterizadas pelo suporte profissional, com grande ênfase na busca de uma reabilitação física. No entanto, o suporte espiritual aparece com uma freqüência significativa em suas falas ressaltando-se, também, a grande representatividade do suporte social nos depoimentos de seus familiares.

Apesar de todas as dificuldades físicas, psíquicas e sociais advindas de uma lesão medular, seus relatos revelaram a predominância de uma percepção positiva de sua deficiência e um afastamento de um auto-conceito marcado pela vitimização. Há, ao contrário, uma aproximação das características apontadas por Vaillant (2000), no seu conceito de "defesas amadurecidas", conforme anteriormente mencionado. Em suas falas, parece haver a consciência de que, embora tenha trazido muitas perdas, a lesão medular possibilitou a estas pessoas uma nova perspectiva de vida. Perspectiva esta que parece possuir uma conotação mais positiva do que negativa.

Observa-se que estas pessoas não se referem a uma aceitação da deficiência em si, já que acreditam e buscam a sua recuperação, mas sim da sua condição atual enquanto deficiente físico acometido por uma lesão medular. Pode-se afirmar, baseado nestes pressupostos, a existência de uma aceitação, como a que é defendida por Vash (1988), na qual estas pessoas assumem a sua identidade como deficiente. Observa-se, ainda, o predomínio da transcendência, como relatada por essa mesma autora. 
É importante ressaltar que compreendem a dependência proveniente do advento de sua deficiência como o principal efeito negativo advindo da lesão medular, já que se consideram pessoas semi-independentes. Esta semi-independência, porém, encontra-se relacionada, predominantemente, ao aspecto físico, ou seja, as dificuldades e facilidades em estar se locomovendo de um lugar para o outro e em estar realizando algumas atividades de vida diária.

Este fato, somado à ênfase dada às suas dificuldades no condicionamento e estruturação corporal e na sua locomoção, podem justificar os esforços e dedicação empreendidos por estas pessoas, no seu restabelecimento físico (suporte profissional). Convém esclarecer, neste contexto, que estas mesmas pessoas, concebem o termo "reabilitação" como sendo, principalmente, as ações voltadas para o restabelecimento das funções corporais que lhes foram subtraídas, para a recuperação de sua locomoção (voltar a andar) ou para uma habilitação funcional, que lhes propiciem uma maior independência na condição de cadeirantes. Caracterizando a interiorização e cristalização de uma percepção, na qual a reabilitação busca alcançar uma condição para o deficiente que esteja mais próxima do padrão de normalidade e baseada na lógica cientificista, detiveram-se, exclusivamente, na adaptação do deficiente à sociedade e não o contrário (ROCHA, 1999). No entanto, embora tenham reconhecido a obtenção de inúmeros benefícios físicos obtidos em seu processo reabilitacional, até o presente momento, observou-se uma maior valorização dos benefícios pessoais que lhes foram proporcionados com os mesmos. Estas afirmações refletem a impossibilidade de uma real separação entre mente e corpo, em um indivíduo que se coloca o tempo inteiro, inclusive no espaço destinado a sua reabilitação, como um ser biopsicossocial (VASH, 1988), com todas as questões e necessidades inerentes a esta condição.

A percepção de uma reabilitação direcionada especificamente para a possibilidade de atingir melhorias físicas e funcionais, contrapõe-se, de uma certa maneira, às necessidades apontadas por estas pessoas de uma atuação que promova o atendimento de suas dificuldades de inserção social devido às barreiras arquitetônicas, além das necessidades de acesso ao mercado de trabalho e políticas de apoio ao deficiente. A necessidade da pessoa 
com lesão medular, de acesso aos serviços de saúde, de uma forma geral, é ressaltada e, novamente, traduz a preocupação dos entrevistados com suas condições físicas e fisiológicas. Todas estas necessidades vem ao encontro do que De Jong (1979) destaca como as condições necessárias para uma maior autonomia do deficiente físico.

O acesso aos avanços científicos na saúde e aos conhecimentos mais recentes provenientes de resultados de pesquisas sobre esta população é apontado, pelos entrevistados, como uma das necessidades da pessoa com lesão medular. Fato este que evidencia um posicionamento baseado na valorização de explicações validadas e reconhecidas pela comunidade científica.

Constatou-se que os usuários que se encontravam realizando o tratamento com a EENM, por um tempo maior que um ano, constituem-se de um grupo de pessoas que se beneficiam de um largo acesso às informações que circulam via revistas, internet e televisão, além de revelarem um grande interesse por tratamentos que possam beneficiá-los de alguma forma. Em relação aos que estão no programa a menos de um ano, o acesso a EENM ocorreu também, em grande proporção, por meio de encaminhamentos médicos, o que revela um aumento na abrangência deste mesmo programa. A maior parte dos entrevistados teve acesso ao Programa de EENM, através de divulgação na mídia, entretanto, as pessoas do grupo 1, acreditam estar realizando este tratamento devido a uma intervenção divina. Podese afirmar, neste caso, a sobreposição do suporte espiritual, sobre o profissional. Suas esperanças e expectativas passam a estar em função deste "poder superior" e não, ao saber científico. O contrário foi mostrado nos depoimentos das pessoas que participam deste tratamento há um tempo mais restrito. No entanto, os que possuem um tempo maior de tratamento, embora acreditem na sua relevância científica, e mostrem, como citado acima, uma crença maior em um suporte espiritual, são capazes de compreender a importância de sua própria contribuição para o êxito de sua reabilitação.

Pôde-se perceber, ainda, através dos resultados obtidos, que os entrevistados acreditam que os relacionamentos sociais devem assumir um lugar importante na vida de uma pessoa acometida por uma deficiência física e devem estar relacionados com um aperfeiçoamento 
de suas habilidades sociais, como também, com o exercício de um papel de conscientização social sobre a lesão medular, suas conseqüências e suas reais limitações. Eles ressaltaram que os problemas relacionados com a interação social e o preconceito são as principais dificuldades apresentadas pelo portador de lesão medular.

A maior parte dos entrevistados acreditava na existência de preconceito, ou em uma percepção irreal da sociedade quanto ao deficiente físico. Eles compreendem que esta percepção é originaria do meio social, quando o mesmo revela uma dificuldade ou limitação em lidar com a deficiência, resultando em estranhamento e indiferença, já que as pessoas acometidas por alguma deficiência, não se encontram enquadradas no conceito de "normalidade", instituído socialmente.

De acordo com os entrevistados, este preconceito pode ser internalizado pela pessoa com lesão medular (ROCHA, 1990) e tem que necessariamente ser revisto e repensado, para que possam assumir perante à sociedade a sua verdadeira condição. Este processo de reflexão interiorizada irá permitir que a pessoa com lesão medular se perceba como um ser capaz e não como um "deficiente". Ela passa a enxergar não somente as suas limitações, mas também, as suas possibilidades. Com esta consciência, ela torna-se apta para expressar-se e impor-se perante a sociedade.É perceptível, portanto, uma modificação importante no que diz respeito a sua identidade social. Eles acreditam que, através do exercício de suas atividades sociais e profissionais, podem estar mostrando suas capacidades e desmistificando idéias pré-concebidas e estigmatizantes, estabelecendo-se, portanto, como sujeitos ativos e participativos dentro do seu contexto social.

Eles ressaltam que a mudança na forma de perceber e até tratar o deficiente físico com lesão medular, irá ocorrer a partir de uma convivência maior com as pessoas portadoras desta patologia. Por meio deste conhecimento e desta convivência, a deficiência deixa de ser o foco de atenção principal para dar lugar à pessoa, ao indivíduo na sua totalidade. Em seus relacionamentos sociais e profissionais, buscavam um maior reconhecimento de suas capacidades, sentimentos, vontades, além de uma maior autonomia, no intuito de serem percebidos na sua totalidade. De acordo com Amaral (1996), o deficiente não é 
contemplado em toda a sua unicidade psicossocial mas, sim, com uma ênfase na sua patologia, passando a ser visto de maneira equivocada e estigmatizada.

No entanto, embora afirmem a ocorrência de mudanças em suas vidas sociais, devido a concepções estigmatizantes e excludentes ocorridas em seus relacionamentos sociais, atestam não possuírem, atualmente, dificuldade de interação social, já que avaliam sua vida social nas categorias de "normal" a "boa". Esta encontra-se relacionada, principalmente, aos relacionamentos afetivos, como as relações de amizades e na vida familiar, o que enfatiza a importância atribuída aos relacionamentos interpessoais.

Os entrevistados mostraram, na sua maioria, uma interrupção na execução de suas atividades profissionais e ocupacionais devido à ocorrência da lesão medular, com alguns relatos evidenciando o exercício de atividades ocupacionais esporádicas, atividades profissionais sistematizadas ou a situação de aposentados e reformados pelo exército. Cabe ressaltar que a maior parte destas pessoas, não completou a sua formação escolar.

O trabalho, para estes entrevistados, pode significar, tanto a possibilidade de estar se realizando profissionalmente e estar gerando sentimentos de orgulho pelo que faz e de utilidade, quanto pode estar relacionado a perdas, promovendo uma reação de tristeza.

Além das dificuldades relativas à imagem social de sua patologia e os estigmas que a ela se relacionam, o trabalho apresenta dificuldades ocasionadas pela inexistência de adaptações arquitetônicas, embora um número significativo destas pessoas argumentaram não terem enfrentado dificuldades em relação a este aspecto (acessibilidade e adaptações arquitetônicas). Os entrevistados acreditavam que a lesão medular não apresenta influência significativa na execução de um trabalho, desde que haja possibilidades de adaptar os espaços e equipamentos utilizados. Todas estas informações mostram a situação de "desvantagem" em que estas pessoas se encontram junto à sociedade da qual fazem parte.

Os comportamentos das famílias, percebidos pelos entrevistados e pelos próprios familiares, apontam para uma forma de enfrentamento marcada pela tentativa de adaptação 
à situação enfrentada, assumindo, após a ocorrência da lesão medular, uma nova forma de vida, quer pela busca de um suporte social, espiritual ou mesmo pela aceitação passiva. No caso dos familiares, não se encontra presente o suporte profissional, como é evidente nos dados relativos aos entrevistados, embora esteja destacado o incentivo dado por estas famílias para que a pessoa com lesão medular possa alcançar uma maior autonomia e independência, podendo se caracterizar, em alguns casos, como um esforço para que seus membros deficientes possam realizar tratamentos reabilitacionais, visto compreenderem a existência de dependência, como um dos principais efeitos provenientes da lesão medular. Entretanto, faz-se necessário ressaltar que tais comportamentos e compreensão, não impedem a ocorrência de relacionamentos de interdependência entre as pessoas com lesão medular e seus familiares, de acordo com os relatos de seus familiares.

É importante notar a existência de formas de enfrentamento diferentes em relação às apresentadas pelos entrevistados e seus familiares. Observou-se, nestas famílias, uma reestruturação significativa de suas vidas, com o intuito de se adaptarem à deficiência de seus familiares, o que revela o impacto da lesão medular no contexto familiar. No caso das pessoas com lesão medular, tal reestruturação também está presente, porém, estabelecendose, principalmente, como uma modificação em seus objetivos de vida, que, a partir do advento da lesão, passam a ser o restabelecimento físico e funcional (reabilitação física e funcional).

O relacionamento familiar, de acordo com os entrevistados, pode se constituir, na sua maior parte, em uma relação familiar estendida, marcada pela lealdade intergeracional, preconizada por Scabini (1992), ou pela constituição da família nuclear. Eles também apontam para um relacionamento estável, onde a sua participação e contribuição neste contexto são preponderantes.

As famílias participam, de forma ativa, na reabilitação de seus familiares com lesão medular. No entanto, a forma de participação mais destacada, consiste no acompanhamento de todo o seu processo reabilitacional e sua maior contribuição consiste no suporte afetivo (apoio). Este “apoio" é afirmado por Vash (1988) como fundamental para a pessoa 
acometida por uma deficiência, ajudando-a e estimulando-a a continuar acreditando em uma vida promissora, apesar de todas as perdas sofridas com a sua patologia. Confirma-se, a partir destes resultados, a necessidade de uma prática reabilitacional que possa estar contemplando também esta família (MINUCHIN e FISHMAN, 1990), oferecendo-lhes uma rede de suporte social (MATSUKURA, 2001).

Estes familiares mencionam, com maior ênfase, os efeitos da deficiência, no portador de lesão medular. Eles ressaltam os efeitos secundários e pessoais, destacando-se a dependência, ocorrência de depressão e dedicação extrema à reabilitação. A dedicação excessiva ao processo reabilitacional, apontada pelos familiares como uma característica dos entrevistados, contradiz, de uma certa maneira, as falas trazidas pelos entrevistados e pelos próprios familiares, nas quais, ressaltam a importância atribuída a reabilitação para suas vidas, mas apontam para a busca de uma realização, também, nos aspectos pessoais, sociais, espirituais e familiares.

Ainda de acordo com estes resultados, observa-se que o destaque para a dependência, dedicação a reabilitação e para a utilização de um suporte profissional como forma de enfrentamento, reafirmam os resultados obtidos na análise dos relatos dos entrevistados. No entanto, não foi observada em tais relatos, a ocorrência de depressão, mas, ao contrário, houve um predomínio de uma avaliação positiva dos efeitos advindos da lesão, embora se sobreponha a esta avaliação uma percepção de si mesmos marcada pela semiindependência.

Green, Pratt e Grigsby (1984) observaram que o aumento da capacidade de se tornar mais independente funcionalmente, produz influências benéficas para o auto-conceito destas pessoas. Partindo destes princípios, fatores como o alcance de uma maior funcionalidade observada através de tratamentos reabilitacionais como a EENM, poderiam estar ou não relacionados a um auto-conceito adequado e satisfatório. Entretanto, seriam necessárias novas pesquisas contemplando os resultados obtidos com a reabilitação e auto-conceito das pessoas envolvidas. 
Os entrevistados apontam diversas mudanças positivas em suas vidas resultantes da aplicação de EENM, atingindo os âmbitos físicos, pessoais (psicológicos) e sociais. O aspecto físico é o mais beneficiado, com ênfase no fortalecimento muscular e aumento da sensibilidade, com uma alusão ao aparecimento de movimentos voluntários em um dos relatos do grupo 2. Com o fortalecimento físico proporcionado por este tratamento, estas pessoas se sentiam mais seguras para estarem buscando a superação de suas limitações. É importante destacar o aumento da auto-estima, já que a EENM proporciona algumas mudanças na maneira dessas pessoas se perceberem e de se colocarem perante a sociedade. Observa-se, a partir da utilização da EENM, e devido à possibilidade de "ficar de pé" e realizar a marcha, a ocorrência de um aumento na sua auto-estima, na autoconfiança, na sua motivação e melhorias em relação a sua auto-imagem e auto-conceito, já que estes efeitos podem ser percebidos com maior intensidade, nos indivíduos que se encontram realizando o tratamento a um tempo mais prolongado e, conseqüentemente, sendo na sua maior parte, contemplados com o objetivo deste tipo de tratamento que se constitui na realização artificial da marcha. As pessoas que se encontram neste tratamento há menos tempo, embora não relatem um aumento na auto-estima proveniente do mesmo, apontam para uma perspectiva para o futuro mais otimista como resultado da aplicação de EENM. Esta reação, juntamente com a percepção positiva destas pessoas em relação a sua deficiência, comprovam a hipótese levantada nesta pesquisa, quanto aos efeitos benéficos deste tipo de intervenção reabilitacional sobre as pessoas com lesão medular. A promoção de uma maior socialização com pessoas acometidas pela mesma patologia, possibilitando a troca de experiências e conhecimentos, é um efeito relatado apenas pelos participantes do grupo 1.

A interação e o aprendizado social provenientes da convivência com pessoas que apresentam a mesma patologia e conseqüentes limitações, como também, o convívio social de uma forma geral, podem se constituir nos fatores promotores das melhorias observadas no seu autoconceito e na percepção mais positiva de sua própria deficiência, já que proporcionam, ao mesmo tempo, um maior aprendizado sobre as suas possibilidades e confiança em suas capacidades. No entanto, seria necessária a realização de estudos que possam estar aprofundando estes aspectos, conforme anteriormente mencionado. 
Observou-se, em relação à expectativa quanto a este tratamento, uma diferenciação entre as pessoas que faziam parte do grupo $1 \mathrm{e}$ as do grupo 2. Nas pessoas do grupo 1, suas expectativas encontravam-se direcionadas, principalmente, para o restabelecimento de sua locomoção (voltar a andar), enquanto que para as do grupo 2, estas expectativas apontaram principalmente, para o restabelecimento parcial de seus movimentos, fazendo-se saber que, neste grupo em específico, ao contrário do anterior, as expectativas iniciais eram, na sua maioria, inexistentes. Pode-se perceber, entretanto, mudanças ocorridas na expectativa inicial para a expectativa atual dos entrevistados. Houve, em relação aos dois grupos supracitados, um aumento das esperanças na recuperação da locomoção (total ou parcial) e uma maior expectativa quanto ao alcance de melhorias físicas e recuperação funcional, no caso do grupo 1. Para o grupo 2 , foi observada, também, uma expectativa que se estendia a melhorias em sua qualidade de vida, o que revela uma percepção mais ampla dos efeitos proporcionados por este tratamento. A existência destas expectativas corroboram para uma percepção mais otimista quanto a seu futuro, que, de acordo com Carter (2001), estaria promovendo a estas pessoas, um comportamento mais saudável e adequado para o alcance de sua reabilitação. Observou-se, ainda, que as expectativas do grupo 1, tornaram-se mais realísticas e menos imediatistas, embora ainda permanecessem acreditando na recuperação dos movimentos através da associação entre EENM e seus próprios esforços para se recuperarem, enquanto que o grupo 2 , adquiriu alguma expectativa positiva durante o tempo em que esteve realizando o tratamento.

Os conhecimentos adquiridos sobre a intervenção através da EENM também contribuem, tanto no que diz respeito às concepções sobre este tratamento, quanto nas expectativas relatadas por estas pessoas. Os entrevistados afirmaram possuírem um conhecimento incompleto sobre este tipo de tratamento e, na sua maior parte, buscavam obter mais informações através de consultas aos profissionais que faziam parte deste programa ou através da observação durante a realização do tratamento. A diferenciação entre o grupo 1 e o grupo 2, foi novamente observada quanto à dificuldade de acesso às informações, podendo-se denotar a existência, no grupo 2 , de um total desconhecimento sobre do que se tratava o tratamento através da EENM, o que aponta para a necessidade de um maior 
esclarecimento a estas pessoas, já que se constatou anteriormente, uma participação passiva das mesmas, se comparadas às pessoas pertencentes ao grupo1, em relação ao modo como entraram em contato com este programa (encaminhamento médico).

Algumas questões, no entanto, relativas a este programa, denotam estar nitidamente compreendidas por estes dois grupos. Seriam elas às que se referem aos resultados já observados por meio deste tipo de tratamento e o seu caráter científico, constituindo-se, portanto, em uma tentativa de recuperação e não em uma garantia, ou mesmo, em uma promessa, esteja ela relacionada a qualquer tipo de melhoria baseada em um tempo mais ou menos determinado.

$\mathrm{Na}$ sua maioria, concebem o tratamento com a EENM como um estímulo diretamente aplicado no músculo, ocasionando a contração muscular (efeito primário) e diversos efeitos físicos secundários, ressaltando-se para o grupo 1, o fortalecimento muscular.

As expectativas relacionadas com o tratamento realizada por meio da EENM vão ao encontro dos resultados observados quanto as suas expectativas para o futuro, já que os participantes do grupo 1 enfatizam a reabilitação de suas funções físicas de uma forma geral, quando se referem às suas expectativas para o futuro, enquanto que os participantes do grupo 2 esperam se realizar plenamente em seus papéis sociais, familiares e profissionais, obtendo, portanto, uma melhor "qualidade de vida".

Os entrevistados parecem estar sempre preocupados em se preparar para alcançar a recuperação de sua locomoção, o que não revela uma espera passiva mas, ao contrário, indica atividades em busca de um aperfeiçoamento físico e psicossocial. Pode-se dizer que a esperança em "voltar a andar", pode se apresentar como uma motivação, para que continuem as suas vidas, podendo exercer seus papéis sociais, profissionais e relacionais, de uma forma geral, embora esta não seja uma condição imperativa para o exercício destes papéis. 
Não obstante, também, constatou-se que a própria lesão medular tornou-se responsável por uma maior valorização de suas vidas e relações psicossociais. Vash (1988) ressalta que a própria deficiência pode se constituir como um estímulo para o desenvolvimento de uma filosofia de vida voltada para a busca de uma maximização de seus recursos internos, aumentando, assim, suas habilidades de relacionamentos intra e interpessoais.

Para inferir, com maior precisão, os efeitos da aplicação da EENM no auto-conceito destas pessoas e, também, nas suas relações sociais e expectativas para o futuro, seria necessária a realização de novos estudos que comparem as características de dois grupos com o mesmo perfil sócio-econômico. Um sendo constituído por usuários de EENM, e outro por não usuários desta mesma tecnologia.

A avaliação do Programa de EENM pelos entrevistados, permitiu um maior esclarecimento sobre as necessidades de modificações no seu funcionamento e chamam a atenção para a organização dos atendimentos e, também, no que diz respeito à manutenção e quantidade de aparelhos de estimulação. No entanto, observa-se uma valorização em relação à forma com que são atendidos neste programa, no que se refere ao interesse, dedicação e atuação dos profissionais que dele fazem parte. $\mathrm{O}$ espaço em que o mesmo vem sendo realizado ultimamente, também, foi enfocado como um aspecto positivo, devido a sua amplitude e estrutura arquitetônica.

Quanto a equipe de profissionais, foi enfatizada no grupo 1, a necessidade de alguns profissionais, tais como, nutricionistas, cardiologistas, neurologistas, especialistas em eletrônica e, especialmente, do profissional psicólogo. Para o grupo 2, entretanto, não haveria necessidade de qualquer inclusão na equipe reabilitacional. Neste caso, é necessário enfatizar a influência do tempo de tratamento nesta avaliação. São ressaltados os benefícios pessoais e afetivos que devem ser adquiridos com uma atuação terapêutica do profissional psicólogo junto à pessoa com lesão medular.

Todas as suas percepções relativas ao meio social e profissional enfocam a necessidade de uma reestruturação nos valores sociais e adaptações arquitetônicas ou ambientais, 
possibilitando o exercício pleno de seus papéis sociais e profissionais, o que evidencia um enfoque nas problemáticas referentes à sociedade como um todo e não apenas ao deficiente. Confrontando estes dados com a percepção que possuem da atuação do psicólogo, observase que, com em alguns poucos relatos, é apontada a importância de um enfoque de intervenção familiar e social. A imagem tradicional do psicólogo com intervenção exclusivamente clínica e focalizada no cliente (no caso a pessoa com lesão medular), parece predominar na concepção que estas pessoas possuem sobre a atuação deste profissional.

Embora tenha sido observada a necessidade de mudanças sociais e de uma intervenção mais ampla, englobando não somente a pessoa acometida pela deficiência, mas toda a sociedade, necessariamente envolvida no seu processo de segregação, tal necessidade não é abordada com clareza por esta população, como uma possibilidade de atuação focalizada. A necessidade de uma sociedade que busque alternativas para a inserção da pessoa com lesão medular (na sua condição de deficiente físico e cadeirante), de maneira a assumir o compromisso de incluí-las socialmente, assegurando o seu direito de participação social (SANTOS, 1995) é levantada em vários de seus depoimentos, porém, sem que a mesma esteja associada às concepções e atuações relativas às práticas reabilitacionais.

Entretanto, a importância atribuída pelos participantes, as práticas reabilitacionais e o empenho empreendido para sua reabilitação, confirmam a hipótese levantada pela pesquisadora, de que os participantes desta pesquisa constituem-se em um grupo engajado, de forma especial, em sua reabilitação.

Esta pesquisa vem reafirmar a importância e necessidade de mais pesquisas que busquem o aprofundamento de todas estas questões, com o intuito de um maior esclarecimento, sobre a possibilidade de um enfoque reabilitacional, que possa estar contemplando o individuo no que concerne às suas dificuldades e necessidades físicas, pessoais, sociais e familiares, conjugadamente.

Para isto, seriam necessários estudos que objetivem conhecer as variáveis que interferem sobre o ambiente familiar e profissional das pessoas com lesão medular e como elas afetam 
o curso de desenvolvimento das mesmas, além de conhecimentos mais precisos das variáveis que interferem sobre os vários tipos de tratamentos e como estes afetam a evolução destes pacientes e usuários.

A partir de todas as informações obtidas com esta pesquisa, fez-se possível uma melhor compreensão de pessoas com lesão medular e submetidos ao tratamento com a EENM, de maneira a possibilitar uma prática reabilitacional que esteja voltada para a realidade e necessidades destas pessoas, abordando seu quadro clínico, familiar, profissional, social e afetivo, tendo atingido, desta forma, os objetivos inicialmente definidos. A sua realidade reabilitacional foi também destacada nesta pesquisa com o intuito de compreendê-la e buscar melhorá-la. Espera-se que estas conclusões possam contribuir na tentativa de implantar uma reabilitação que atenda a estas pessoas de forma totalitária, e não somente à deficiência e seus efeitos físicos, resultantes de um diagnóstico pré-concebido. Destaca-se a importância da realização de pesquisas, enfocando as necessidades da pessoa que está sendo reabilitada, nas quais a mesma, possa estar participando, sendo a fonte de informações sobre as suas necessidades, para que estas possam se constituir como objetivos de tais práticas.

Para a realização de uma intervenção baseada em tais pressupostos, pode-se sugerir a implementação de um trabalho sistemático com as pessoas com lesão medular e seus "outros significativos", a saber: pais, irmãos, amigos e outros. De acordo com Araújo (2001), tal trabalho estaria caracterizado pela organização de reuniões periódicas; discussão passo a passo das dificuldades apresentadas pelas pessoas com lesão medular; desenvolvimento de observações e de outros instrumentos de coleta de informações; implementação de registros sistemáticos referentes às informações obtidas; encaminhamento de decisões conjuntas sobre os modos de intervir em relação às necessidades e dificuldades detectadas; acompanhamento dos modos de intervir e fornecimento de "feedback" constante sobre os mesmos, enfatizando aspectos positivos e os aspectos que ainda deverão ser melhorados e, finalmente, a avaliação do processo por todos os envolvidos.

\footnotetext{
${ }^{9}$ Manteve-se a expressão indicada por Amaral (1996)
} 
Visto os resultados obtidos neste estudo, ressalta-se a importância da intervenção terapêutica individual, como um recurso que poderá ser eventualmente utilizado, caso se mostre necessário.

Conclui-se, a partir dos resultados obtidos com esta amostra, que a reabilitação deve estar englobando, não somente a pessoa acometida por uma deficiência no seu contexto biopsicossocial, mas também, as pessoas que com ela convivem, incluindo os profissionais de saúde, familiares, seus pares entre outros, buscando uma maior adequação da sociedade às necessidades gerais da referida população. Compreendendo-se a reabilitação deste modo, todas as pessoas envolvidas são beneficiadas, além de favorecer à pessoa com lesão medular, o exercício pleno de seu papel de cidadão e valorizando sua participação como membro integrante e importante dentro da comunidade em que vive. 


\section{Referências Bibliográficas}

ALMEIDA, M.C. (1993). A Pessoa Portadora de Deficiência Física em seu Cotidiano: Reflexos e Reflexões sobre a Reabilitação. São Paulo: Universidade de São Paulo.

AMARAL, L.A. (1996). Deficiência: questões conceituais e alguns de seus desdobramentos. Cadernos de Psicologia, vol.1, p.3-12.

ANDERSON , P.; KITCHIN, R. (2000). Disability, space and sexuality: access to family planning services. Social Science \& Medicine, vol. 51, p. 1163-1173

ANDREWS, B; BAXENDALE, R. (1988). A hibryd orthosis incorporating artificial reflexes for spinal cord damaged patients. J. Physiol, p. 198-380.

ANDREWS, B. J. et. al. (1986). Restoration of locomotion in spinal cord injured subjects using surface FES. IEE Procedings - Control Theory and Applications. London, G. B, UK: vol. Digest, n. 6, p. $1-7$.

ARAÚJO, E.A.C. (2001). Programa de Orientação de Mães para Integração Social de Adultos Portadores de Deficiência Mental. Tese (Doutorado) - Programa de Educação Especial, Universidade Federal de São Carlos, São Paulo, 2001.

BAJD, T. et. al. (1983). The use of a four-channel electrical stimulator as an ambulatory aid for paraplegic patients. Phys Ther, vol. 63, p. 11-16.

BAJD, T; KRALJ, A; TURK, R. (1982). Standing-up of a healthy subject and a paraplegic patient. J. Biomech, vol. 15 , n.1, p. $1-10$.

BARDIN, L. (1977). Análise de Conteúdo. Lisboa: Edições 70.

BARR, F.M.D. (1996).Functional electrical stimulation: another perspective. In: SCIENTIFIC PROGRAMM AND ABSTRACTS OF THE 35 ANNUAL SCIENTIFIC MEETING OF IMSOP, 1996, Royal National Orthopedic Hospital Trust, Stanmore, UK.

BENTON et. al. (1979). Functional Electrical Stimulation - A Practical Clinical Guide the Professional Staff Association of Rancho Los Amigos Hospital, 2a ed.

BERGER, P.L.; LUCKMANN, T. (1983). A construção social da realidade. Petrópolis:Vozes.

BERNHADT, J. (1983). Química e biologia no séc. XIX. In: CHÂTELET, F. História da filosofia -idéias. Doutrinas. A filosofia do mundo científico e industrial (1860-1940). vol. 6, Rio de Janeiro: Zahar.

BIASÓLI - ALVES, Z. M. M. (1996). A família como ambiente de socialização de todas as gerações. Texto digitado não publicado, Universidade de São Paulo, São Paulo. 
BOGOSSIAN, L. (1981). Traumatismo em geral: estudo etiopatológico dos traumas mecânicos. J. Bras. Med, v.41, p.61-70.

BOLLER, F.; FRANK, E. (1982). Sexual Dysfunction in Neurological Disordees: Diagnosis, Manegement and Rehabilitation. New York: Raven Press.

BRADLEY, M.B. (1994). The effect of participating in a functional electrical stimulation exercise program on affect in people with spinal cord injuries. Arch. Phys. Med. Rehabil, v.75, p.676-679.

BRASIL (1989). Lei $\mathrm{n}^{0} 7.853$, de 24 de outubro de 1989. Os direitos das pessoas portadoras de deficiência. Coordenadoria Nacional para integração da pessoa portadora de deficiência - CORDE, Poder Legislativo, Brasília, DF.

BRASIL (1994) Política Nacional de Educação Especial. Brasília: MEC/SEESP.

BRAY, G. P. (1978). Rehabilitation of spinal cord injured: family approach. J. Appl. Rehabl. Counseling, v. 9, p. $70-78$.

BRIAN, C.G.; PRATT, C.C.; GRIGSBY, T.E. (1984). Self - Concept among persons with long-term spinal cord injury. Phys Med Rehabil. vol. 65, p. 751-754.

BROW, D.L. (1996). Personal Implications of Functional Electrical Stimulation Standing for Older Adolescents with Spinal Cord Injuries. Technology and Disability. v. 5, p. 295311.

BRYAN D.P.; HERJANIC B. (1980). Depression and suicide among adolescents and young adults with selective handicapping conditions. Except Ed Q. p.57-65.

CARTER, J. (entre 1999 e 2001). The Aplication of specific techniques of cognitive therapy and Rational Emotive Therapy in Adjustment and Acceptance of Spinal Cord Injury, Disponível em: <http://www.users.sgi.net/ ozzy/sci-docs.htm>. Acesso em: 25 setembro 2002.

CARVALHO, S.A.D et. al. (1998). Spinal Cord Injury and Psychological Response. General Hospital Psychiatry, v. 20, p. 353-359.

CASTRO, M.C.F.; CLIQUET Jr.A. (1997). A Low - Cost Instrumented Glove for Monitoring Forces During Object Manipulation. IEEE Trans. Rehab.Eng, vol. 5, n. 2, p.140-147.

CASTRO, M.C.F.; CLIQUET, Jr. A. (1996). Uma Luva Instrumentalizada para Tetraplégicos. Rev. Bras. Eng. Biomed, v. 12 , n.1, p.41-56.

CHAUÍ, M. (1984). Repressão sexual: Essa nossa (des) conhecida. São Paulo: Brasiliense. 
CHERNOVIZ, P.L.N. (1890). Diccionario de Medicina Popular e das Sciencias Accesarios. Pariz.

CLIQUET, JR.A. (1988). Paraplegic Locomotion with Neuromuscular Electrical Stimulation Based Systems - A Feasibility Study. Tese (Livre-docência) - University of Stratchclyde, Glasgow, UK, 1988.

CLIQUET, JR. A. (1989). Paraplegic Locomotion and its metabolic energy expenditure. In: $-146$. . Comprehensive Neurologic Rehabilitation. New York: Demos Pub, vol. 3, p. 139

CLIQUET, JR. A. (1993). Rehabilitation Engineering at the State University of Campinas. IEE Engineering in Medicine and Biology Magazine. Estados Unidos, vol. 1, n.2, p. 8 - 11.

CLIQUET, JR.A. (2003). A Comprehensive Sensorymotor Rehabilitation Programme for Spinal Cord Injured Patients Using Neuromuscular Electrical Stimulation. In: WORLD CONGRESS ON MEDICAL PHYSICS AND BIOMEDICAL ENGINEERING, Sidney, august 24-29, 2003.

CORBET, B. (1985). National Resourche Directory, Massachusetts: National Spinal Cord Association.

DEJONG, G. (1979). Independent living: from social movement to analytic paradigm. Arch. Phys. Med. Rehabil, v. 60, p. 435 - 446.

DENARI, F.E. (1997). O adolescente especial e a sexualidade: nem anjo, nem fera. Tese (Doutorado) - Programa de Pós-Graduação em Educação, Centro de Educação e Ciências Humanas, Universidade Federal de São Carlos, São Carlos, 1997.

DEWIS, M.E. (1989). Spinal cord injured adolescents and young adults: the meaning of body changes. J. Advan. Nursing, v. 14, p. 389-398.

DIEHL, S.F.; MOFFITT, K.A.; WADE, S.M. (1991). Focus group interview with parents of children with medically complex needs: An intimate look at their perceptions and feelings. Children 's Health Care, v. 20, n. 3, p.170-178.

ENGENHARIA DE REABILITAÇÃO (2004). PED - CEB . Produzido por Centro de Engenharia Biomédica - CEB. Disponível em: <www.unicamp.br/ceb/ped/reabil.html $>$. Acesso em: 27 abril 2004.

EVANS, P.J et. al.(2001). Evaluation of medical rehabilitation in community based rehabilitation. Social Science \& Medicine, v. 53, p.333-348.

FARO, A.C.M. (1991). Estudo das alterações da função sexual em homens paraplégicos. Dissertação (Mestrado) - Escola de Enfermagem da Universidade de São Paulo, Universidade de São Paulo, São Paulo, 1991. 
FARO, A.C.M. (1995). Do diagnóstico à conduta de enfermagem: a trajetória do cuidar na reabilitação do lesado medular. 207p. Tese (Doutorado) - Escola de Enfermagem, Universidade de São Paulo, São Paulo, 1995.

FARO, A.C.M. (1999).Uma proposta de levantamento de dados para a assistência à família e ao cuidador de lesados medulares. Rev. Esc. Enf. USP, v.33, n.4, p. 334-341.

FARO, A.C.M. (2001). Atividades realizadas no domicílio pelo cuidador familiar da pessoa com lesão medular. Rev. Paul. Enf, v. 20, n.2, p.33-43.

FAZENDA, I.C.A. (1979) A Integração e Interdisciplinaridade no Ensino Brasileiro. São Paulo, S.P: Loyola.

FERRARETO, I., (Julho de 2000). Dores nas Costas - Home Page. Disponível em: $<$ http://www.doresnascostas.com.br/coluna.html>. Acesso em: 24 setembro 2001.

FERREIRA, B. de H. A. (1986). Novo Dicionário da Língua Portuguesa. Rio de Janeiro: Editora Nova Fronteira.

FINOCCHIARO, D.N.; HERZFELD S. T. (1990).Understanding Autonomic Dysreflexia. American Journal of Nursing, v.90, p.56-59.

FOUCAULT, M. (1985). Microfísica do poder. Rio de Janeiro: Graal.

FRANCO, J.R. (2002). O significado da cegueira para pessoas que perderam a visão na idade adulta. 109 p. Dissertação (Mestrado) - Programa de Pós-Graduação em Educação Especial, Centro de Educação e Ciências Humanas, Universidade Federal de São Carlos, São Carlos, 2002.

FUKUI, L. (1992) A família no século XXI. Apresentado na $49^{\circ}$ Reunião da Sociedade Brasileira para o Progresso da Ciência, São Paulo, 1992.

GHIRARDI, M.I.G. (1999). Representações da deficiência e práticas de reabilitação: uma análise do discurso técnico. 150p. Tese (Doutorado) - Instituto de Psicologia da Universidade de São Paulo, Universidade de São Paulo, São Paulo, 1999.

GIGNAC, M.A.M.; COTT, C. (1998). A conceptual model of independence and dependance for adults with chronic physical illness and disability. Social Science \& Medicine, v. 41, p. 739-754.

GOFFMAN, E. (1974). Manicômios, prisões e conventos. [ASILUMS - Essays on the social situation of mental patients and other inmates] Trad. Dante Moreira Leite. São Paulo: Perspectiva.

GOFFMAN, E. (1975).A Representação do Eu na Vida Cotidiana. Petrópolis: Vozes. 
GOFFMAN, E. (1988). Estigma: Notas sobre a Manipulação da Identidade Deteriorada. RJ: Editora Guanabara.

GONZALEZ, R.I.C. (2000).O Processo da Alta Hospitalar do Paciente com Lesão Medular: gerenciamento de caso como estratégia de organização do cuidado. Dissertação (Mestrado) - Escola de Enfermagem de Ribeirão Preto, Universidade de São Paulo, Ribeirão Preto, 2000.

GRAUPE, D. (1989). EMG pattern analysis for patient-responsive control of FES in paraplegics for walker-supported walking. IEE Trans Biomed Eng, vol. 36, p. 711-719.

GREEN, B.C.; PRATT, C.C.; GRIGSBY, T.E. (1984). Self-concept among persons with long-term spinal cord injury. Arch. Phys. Med. Rehabil, v. 65, p. 751-754.

GREGG, C.H.; ROBERTUS, J.L.; STONE, J.B. (1989). The psychological aspects of chronic illness. Springfield: Charles C. Thomas.

GREVE et. al. (2001). Diagnóstico e tratamento da lesão da medula espinal. São Paulo: Roca.

GUEST, R.S.; KLOSC, K. J.; GREEN, B.A. (1996). Psychological effects of an electrical stimulation walking program for persons with paraplegia. Journal of spinal cord Medicine, v. $19 ; 2$ (151).

HARRY, B. (1992). Making sense of disability: Low - income, Puerto Rican parents theories of the problem. Exceptional Children, vol. 59, n. 1, p. $27-40$.

HANAK, M.; SCOTT, A. (1983). Spinal Cord Injury. New York: Springer Publishing Company.

HANDA, Y. (1997). Current Topics in Clinical Functional Electrical Stimulation in Japan. J. Electromyogr. Kenesiol., vol. 7, n.4, p. 269-274.

HANSON; BUCKELEW; HEWETT. (1993). The Relationship Between Coping and Adjustment After Spinal Cord Injury: A 5-Year Follow-Up Study. Rehabilitation Psychology, v. 38, p. 41-50.

HELGE, D. (1991). Rural, excepcional, at risk. Reston, VA: Council for Exceptional Children.

HOCKENBERRY, J. (2001). O HomemBiônico. Revista Amanhã - Wired - Ed.170, Disponível em: <http://amanha.terra.com.br/edicoes/170/wired01.asp>. Acesso em: 27 setembro 2001.

IDE, C.A.C.; CHAVES, E.C. (1992). A intervenção do enfermeiro na assistência ao diabético. Rev. Esc. Enfermagem USP, São Paulo, v. 26, n.2, p.187-204. 
INSTITUTO BRASILEIRO DE GEOGRAFIA E ESTATÍSTICA (2000). Censo Demográfico 2000 - Sistema do IBGE de Recuperação Automática - SIDRA. Disponível em: <http:/www.sidra.ibge.gov.br/bda/pesquisas/ctdtabav>. Acesso em: 27 maio.2004.

JAEGER, R; YARKONY, G; SMITH, R. (1989). Standing the spinal cord injured patient by electrical stimulation: Refinement of a protocol for clinical use. IEE Trans Biomed Eng, vol. 36, p. $720-728$.

JONES, D.E. et. al. (1995). Educational placements for children who are ventilator assisted. Lawrence: University of Kansas, Beach Center on Families and Disability.

KALYANPUR, M.; RAO, S.S. (1991). Empowering low - income black families of handicapped children. American Journal of Orthopsychiatry, vol. 61, n. 4, p. 523 - 532.

KHAN A.U.; HERNDON C.H.; AHMADIAN S.Y. (1971). Social and emotional adaptations of children with transplanted kidneys and chronic hemodialyses. Am J. Psychiatry, v.127, p.1194-1198.

KOVACS, M.J. (1997) Deficiência adquirida e qualidade de vida- possibilidades de intervenção psicológica. In: MASINI, E.A.F.S. et al. Deficiência: alternativas de intervenção. São Paulo:Casa do Psicólogo.

KOVÀCS, Z.L. (1997). O Cérebro e Sua Mente: Uma Introdução a Neurociência Computacional. São Paulo:edição acadêmica.

KRALJ, A. et. al. (1983). Gait restoration in paraplegic patients: A feasibility demonstration using multichannel surface electrode FES. J. Rehabil. Res. Dev, vol. 20, p.3 -20 .

LARRY, B.S.A. (1988). Criança Incompreendida. Um guia para os pais de crianças com distúrbios de aprendizagem. Rio de Janeiro: Jorge Zahar Editor.

LAVINE, M.; ROBERTS, L.; SMITH, O. (2002). Bodybuilding: The Bionic Human. Science, v. 295.

LEPRINCE, B. (1981). Le paraplégique. Rev. Infirm., v.12, p. 6-8.

LEVIN, E. (2001). A infância em cena: constituição do sujeito e desenvolvimento psicomotor. Petrópolis, R. J: Vozes.

LEVINE, M.; LEVINE, A. (1970). A social history of the helping services: Clinic, court, school, and community. New York: Appleron-Century-Crofts.

LIANZA, S.; CASALIS, M.E.P.; GREVE, J. M.D. (1985). A lesão medular. In: LIANZA, S. e outros. Medicina de Reabilitação, Rio de Janeiro: Guanabara Koogan.

LIPPINCOTT. (1988). Rehabilitation Medicine: principles and practice. Philadelphia. 
LOUREIRO, S.C.C. ; FARO, A.C.M.; CHAVES, E.C. (1997). Qualidade de Vida sob a Ótica de Pessoas que Apresentam Lesão Medular. Rev.Esc. Enf. USP. v. 31, n.3, p. 347367.

LUBKIN, I.M. (1990). Chronic illness: impact and interventions. Boston: Jones and Bartlett.

LUETKE-STAHLMAN,B. (1991). Moving with a deaf child in the family. Perspectives, v. 9 ,n.5, p. 8-10.

LUZ, M.T. (1988). Natural Racional Social - Razão Médica e Racionalidade Científica Moderna. Rio de Janeiro: Campus.

MANNUCI, E.; RICCA. V.; BARCIULLI, E. (1999). Quality of life and the overweight; the obesity related well-being (Orwell 97) Questionnaire. Addict Behav, v.24, p.345.

MARSOLAIS, E.B., KOBETIC, R. (1987), Functional Electrical Stimulation for walking in paraplegia. J Bone Joint Surg Am; vol.69 A, p. 728-733.

MARTINS, L.M; FRANÇA, A.P.D; KIMURA, M. (1996). Qualidade de Vida de pessoas com doença crônica. Rev. Latino-am. Enfermagem, Ribeirão Preto, v.4, n.3, p.5-18.

MATSUKURA, T. S. (2001). Mães de crianças com necessidades especiais: stress e percepção de suporte social. Tese (Doutorado) - Universidade de São Paulo, Ribeirão Preto, USP, 2001.

MATTHEWS, G. G. (2000). Neurobiology: Molecules, Cells and Systems. Disponível em: $<$ http://www.s2smed.com/matthews/index.html>. Acesso em 24 set.2001.

MAZAS, M.; MATAMORO, V. (1991). Servicios de rehabilitación. s.1., s. ed.

MAZZOTTA, M. J. S. (1996). Educação Especial no Brasil. História e políticas públicas. São Paulo: Cortez Editora.

MAYER, J.D.; EISUNBERG, M.G. (1988). Mental representation of the body: Stability and change in response to illness and disability. Rehabilitation Psychology, vol. 33 , n.3, p.155-171.

MCNEAL, D.R. (1977). 2000 Years of Electrical Stimulation. In: Functional Electrical Stimulation: Applications in Neural Prostheses. edited by F. T. Hambrecht and J. B. Reswick. New York: Marcel Dekker, p 3-35.

MENDES, P.B.M.T. (1998).Cuidadores: heróis anônimos do cotidiano. In: KARSCH, U.M.S. Envelhecimento com dependência: revelando cuidadores. São Paulo: EDUC, cap. 5, p.171-197. 
MERLEAU - PONTY, M. (1980). As aventuras da dialética. In: MERLEAU - PONTY. Os Pensadores. São Paulo: Abril.

MERLEAU - PONTY, M. (1990). O primado da percepção e suas consequencias filosóficas. Campinas: Papirus.

MINUCHIN, S.; FISHMAN, H. C. (1990).Técnicas de terapia familiar. Porto Alegre: Artes Médicas.

NATIONAL COMISSION ON CHILDHOOD DISABILITY. (1995). Supplemental security income for children with disabilities: Report to Congress of the National Comission on Childhood Disability. Washington, DC: Author.

NOSEK, M.A.; FUHRER, M.J. (1992). Independence among people with disabilities: I. A heuristic model. Rehabil. Couns. Bull, v.36, p.6-20.

NOVAES, M.H. (1975).Psicologia Aplicada a Reabilitação. Rio de Janeiro: Ed. Imago.

NOVAK, G. (1996). The Family System. In: __ Developmental Psychology: Dinamical Systems and Behavior Analysis. Nevada: Context Press, p.239-259.

OLIVEIRA, C.E.N. ; SALINA, M.E; ANNUNCIATO, N.F. (2002). Neuroplasticidade: fundamentos para a reabilitação do paciente neurológico adulto. Fisioter. Mov, vol. 14, n.2, p. 11-20.

OLSON, D.H et. al. (1983). Families: What makes them work? Beverly Hills, CA: Sage.

OMOTE, S. (1998). Famílias de Deficientes: Estudos relatados em dissertações e teses. In: MARQUEZINE, C.; ALMEIDA, M.A. Perspectivas Multidisciplinares em Educação Especial . Londrina: Ed. Da UEL, v.1, n.1, p. 125-129.

OMOTE, S. (2003). Algumas possibilidades de uso da fotografia como recurso de pesquisa em educação especial. In: ALMEIDA, M. A; MARQUEZINE, M. C; TANAKA, E. D. Perspectivas multidisciplinares em educação especial. v. 3.

ORGANIZAÇÃO MUNDIAL DA SAÚDE. (1981). Prevencion de incapacidades y rehabilitation. Serie de Informes Técnicos 668, Genebra.

ORGANIZAÇÃO MUNDIAL DA SAÚDE. (1989). Classificação internacional das deficiências, incapacidades e desvantagens (handicaps): um manual de classificação das consequências das doenças. Lisboa.

ORGANIZACION PANAMERICANA DE LA SALUD (OPAS). (1988). Grupo de estudio sobre capacitatión del médico en Medicina Física y Rehabilitation: informe final. Caracas. 
ORTOLAN, R.L et. al. (2001). Tendências em Biomecânica Ortopédica Aplicadas à Reabilitação. Revista Acta Ortopédica Brasileira, v. 9, n. 3, p 44 - 58.

OTERO, G.J.J. (1988). Minusvalias físicas, mentales y sensoriales. In: GIL, P.G (ed.) Medicina preventiva y salud pública. Barcelona, s.ed., p.805-833.

PAULA, A.R.D. (1993). Corpo e deficiência: Espaços do Desejo - Reflexões sob(re) a perspectiva feminina. Dissertação (Mestrado) - Instituto de Psicologia da Universidade de São Paulo, Universidade de São Paulo, São Paulo, 1993.

PECKHAM, PH. (1987). Functional electrical stimulation: Current status and future prospects of applications to the neuromuscular system in spinal cord injury. Paraplegia, vol. 25 , p. $279-285$.

POPOVIC, M.R et al. (2001). Surface-Stimulation Technology for Grasping and Walking Neuroprostheses. IEE Engineering in Medicine and Biology, p. 82 - 93.

QUEIROZ, R. D.S. (1995). Não vi e não gostei: o fenômeno do preconceito. In: Qual é o grilo. São Paulo: Moderna.

QUEVEDO, A. A. F. et. al. (1997). Development of control strategies for restoring function to paralysed upper and lower limbs. In: IEEE Annuais Meeting Engineering in Medicine and Biology Society, 1997, Estados Unidos, p. 1946 - 1949.

QUEVEDO, A. A. F; PATLA, A.; CLIQUET, JR. A. (1997). A Methodology for Definition of Neuromuscular Electrical Stimulation Sequences. Aplication on Overcoming Small Obstacles. IEEE Transactions on Rehabilitation Engineering, vol. 5, n. 1, p. 30 - 39.

QUINTERN, J. (1998). Application of functional electrical stimulation in paraplegic patients. NeuroRehabilitation, v. 10, p. 205-250.

REDE SARAH. (2003). Centro de Pesquisas em Educação e Prevenção da Rede Sarah (CEPES). Disponível em: $<$ http:/www.sarah.br/paginas/prevencao/po/02_01_perf_gera_causas_ext.pdf $>$. Acesso em: 05 abril 2004.

RIBEIRO, M.S. (1989). A questão da família na atualidade. Dissertação (Mestrado) IOESC, Ministério da Justiça e da Secretaria de Estado do Desenvolvimento social e da família, Florianópolis, 1989.

RIBEIRO, S.J.B. (1995). Neuroplasticidade e a recuperação da função após lesões cerebrais. Acta Fisiátrica, v. 2, n. 3, p. 27-30, dez..

RICHINSKAS, R; O'GRADY, T. (2000). Psychological variables predict decisions regarding emplantation of a spinal cord stimulation. Neuromodulation, v. 3, n. 4, p.183189, October. 
ROCHA, E.F. (1990). Corpo Deficiente: Em busca da Reabilitação? Uma reflexão a partir da ótica das pessoas portadoras de deficiências físicas. Dissertação (Mestrado) - Instituto de Psicologia da Universidade de São Paulo, Universidade de São Paulo, São Paulo, 1990.

ROCHA, E.F. (1991). Corpo deficiente: um desvio da norma? Revista de Terapia Ocupacional da USP, São Paulo, v.2, n.4, p.182-187.

ROCHA, E.F. (1999). Do corpo orgânico ao corpo relacional: uma proposta de deslocamento dos fundamentos e práticas de reabilitação da deficiência. $237 \mathrm{p}$, Tese (Doutorado) - Instituto de Psicologia, Universidade de São Paulo, São Paulo, 1999.

ROSENBERG, M. (1965). Society and the Adolescent Self-image. Princeton: Princeton University Press.

SÁ, M.P.C. (1982). Abordagem teórica da essência e do apoio na reabilitação do paraplégico. Recife: Ed. Gráfica e Papelaria Star.

SALAMANCA. (1994). Sobre príncipios, política e prática em Educação Especial. In: Educação on Line. Disponível em: <http://trade regra.com.br (nossos clientes)>. Acesso em: 29 maio 2004.

SAliMENE, A. C. M. (1995). Sexo: Caminho para a Reabilitação. São Paulo, Cortez.

SANTOS, L.C.R. (1989). Lesão traumática da medula espinhal: estudo retrospectivo de pacientes internados no Instituto de Ortopedia e Traumatologia do Hospital das Clínicas da Faculdade de Medicina da Universidade de São Paulo entre 1982-1987. Dissertação (Mestrado) - Escola de Enfermagem, Universidade de São Paulo, São Paulo, 1989.

SANTOS, L.C.R. (2000). Re dimensionando limitações e possibilidades: a trajetória da pessoa com lesão medular traumática. 144p, Tese (Doutorado) - Escola de Enfermagem, Universidade de São Paulo, São Paulo, 2000.

SANTOS, M.P. (1995) Perspectiva histórica do movimento integracionista na Europa. Revista Brasileira de Educação Especial. Piracicaba: UNIMEP, v. 3, p. 21-29.

SANTOS, M.P. (2000). Educação inclusiva e a declaração de Salamanca: conseqüências ao sistema educacional brasileiro. Integração. Brasília: SEESP/MEC, v.22, p. 34-40.

SASAHARA, R.M. (1980). Assistência de enfermagem ao paraplégico. In: NAKAJO, A.S.H. et al. Temas de enfermagem ortopédica e traumatológica. São Paulo, Instituto de Ortopedia e Traumatologia do Hospital das Clínicas da Faculdade de Medicina da USP, p.50-55.

SASSAKI, R. K. (1998) Entrevista. Integração. Brasília: SEESP/MEC, v. 20, p. 08-10. 
SCABINI, E. (1992). Ciclo de vida familiar e ciclo de saúde familiar. Centro de Estudos e pesquisas sobre Família. Universidade Católica do Sagrado Coração de Jesus, Milão, Itália (Manuscrito).

SCHERB, E M.K. (1998). Deficiência física adquirida por lesão medular traumática: estudo da auto-imagem. 178 páginas, Dissertação (Mestrado) - Instituto de Psicologia, Universidade de São Paulo, São Paulo, 1998.

SELIGMAN, M. E. P; CSIKSZENTMIHALYI, M. (2000). Positive Psychology - An introduction. American Psychologist, vol.55, n.1, p. 5-14, jan..

SELKOWITZ, D. M. (1985). Improvement in Isometric Strength of Quadriceps Femoris Muscle After Training with Electrical Stimulation. Physical Therapy. v. 65, n. 2, p. 186196.

SEPULVEDA, F; CLIQUET, JR. A. (1996). Artificial neural network based system for neuromuscular electrical stimulation induced gait. Artificial Organs, v. 20, n. 11, p. 1245.

SEPULVEDA, F; GRANAT, M. H; CLIQUET, JR. A. (1998). A gait Restoration in a Spinal Cord Injured subject via Neuromuscular Electrical Stimulation Controlled by Artificial Neural Network. The International Journal of Artificial Organs, v. 21, n. 1, p. 49 -62 .

SILVA, I.P. (1998). As relações de poder no cotidiano de mulheres cuidadoras. In: KARSCH, U.M.S (org). Envelhecimento com dependência: revelando cuidadores. São Paulo, EDUC, cap.4, p.147-170.

SILVA, M.P.L. \& DESSEN, M.A. (1999). Análise da Produção Científica Internacional e Nacional na Área de Deficiência Mental e Família. In: XXIX REUNIÃO ANUAL DE PSICOLOGIA, 1999, Campinas/ SP, p.1-10.

SOLOMON, J. (1982). Sex and the spinal cord injured patient. J. Neurosurg. Nurs,v.14, p.125-127.

SOUZA, P.A. (1994). O Esporte na Paraplegia e Tetraplegia. Rio de Janeiro: Editora Guanabara Koogan S.A.

SPOSITO, M. M. de M. et al. (1986). Paraplegia por lesão medular: estudo epidemiológico em pacientes atendidos para reabilitação. Rev. Paul. Med., v.104, p.196-202.

STASS Jr., W.E. et al. (1992). Reabilitação do paciente com traumatismo raquimedular. In: DELISA, J.A. Medicina de reabilitação: príncipios e prática. São Paulo, Manole, v.2, p.735-762.

TERRASI, E.A. (1993). Família do Deficiente: Aspectos Comuns e Específicos Relatados pelas Mães de Crianças Portadoras de Diferentes Deficiências. Dissertação (Mestrado) Universidade Federal de São Carlos, São Paulo, 1993. 
TIEFER, L. (1979). A sexualidade humana: sentimentos e funções. São Paulo: Harper \& Row do Brasil.

TIMMERECK, T.C.; SURVER, J. (1986). Dictionary of Healthy Services Management. National Health Publishing.

TOMÁS, A.T.; LLARAS, A.R. (1997). Cuidadores a los cuidadores. Rev. ROL Enf, n. 222, p. 13-15.

TRIESCHMANN, R.B. (1988). Spinal cord injuries: psychological social and vocational rehabilitation. New York: Demos.

TRIOLO, R. J.; KOBETIC, R.; BETZ, R. R. (1996). Standing and walking with Functional Neuromuscular Stimulation: Technical and Clinical Challenges, In: HARRIS, G.F.; SMITH, P.A. Human Motion Analysis: Current Applications and Future Directions, IEEE Press, New York, p 318-350.

TURNBULL, A.P; TURNBULL, H.R. (1997). Family Characteristics. In: Family, Professionals and Exceptionality: A Special Partnership. $3^{\mathrm{a}}$ ed., Columbus; Merrill Publishing Company, p.80-92.

VAILLANT, G.E. (2000). Adaptive mental mechanisms: Their role in a positive psychology. American Psychologist, vol. 55, p. $89-98$.

VASH, C.L. (1988). Enfrentando a deficiência. São Paulo: Pioneira/ EDUSP.

VIEIRA, T. T. (1976). Importância da imagem corporal na prática da enfermagem. Tese (Livre - docência) - Escola de Enfermagem Ana Nery, Rio de Janeiro, 1976.

VITAL, I. L.V. (1996). Atendimento em grupo a mães de deficientes mentais, inspirado nas concepções de J. L. Moreno. Dissertação (Mestrado) - Programa de Pós-Graduação em Educação Especial, Centro de Educação e Ciências Humanas, Universidade Federal de São Carlos, São Carlos, 1996.

WARE, J.E. (1995). The status of health assessment 1994. Rev.Public Health, n.16, p.327.

WEINBERG, J.S. (1982). Human sexuality and spinal cord injury. Nurs. Clin. North. Am., v. 17, p. $407-19$.

WERNER, D. (1994). Guia de Deficiências e Reabilitação Simplificada: Para Crianças e Jovens Portadores de Deficiência, Famílias, Comunidades, Técnicos de Reabilitação e Agentes Comunitários de Saúde. Brasília: CORDE.

WILLIANS, L.C.A; AIELLO, A.L.R. (2003). Empoderamento de famílias: o que avaliar e como medir. Apresentado ao I Congresso Brasileiro de Educação Especial, São Carlos, 2003. No prelo. 
WILSON, D. J. et. al. (1984). Spinal Cord Injury: A Treatment Guide for Occupational Therapists. New Jersey: Slack Incorporated.

YARKONY, G.M.J. et. al. (1990). Functional neuromuscular stimulation for standing after spinal cord injury. Arch. Phys. Med. Rehab, vol, 70, p. $201-206$.

YOSHIOKA, J. M. (1980). Aspectos assistenciais de enfermagem aos pacientes na fase aguda do traumatismo da coluna vertebral. In: NAKAJO, A.S.H. et al. Temas de enfermagem ortopédica e traumatológica. 2 ed. São Paulo, Instituto de Ortopedia e Traumatologia do Hospital das Clínicas da Faculdade de Medicina da USP. p.44-49.

YOUNG, J. et. al. (1982). Spinal Cord Injury Statistics. Phoenix, Arizona: Good Samaritan Medical Center. 
APÊNDICE A - Roteiro de entrevista para caracterização da pessoa com lesão medular 


\section{Entrevista para Caracterização da Pessoa com Lesão Medular}

\section{1) Dados de Identificação}

sexo ( ) F ( ) M

idade: cor

estado civil/marital:

prática espiritual / religião:

escolaridade: ( ) não sabe ler e escrever

( ) não sabe ler e escrever., mas assina o nome

( ) lê e escreve com dificuldade

( ) $1^{\circ}$ grau completo ( ) incompleto

( ) $2^{\circ}$ grau completo ( ) incompleto

( ) superior completo ( ) incompleto

( ) pós-graduação completa ( ) incompleta

Se estuda atualmente, colocar aqui que nível está cursando profissão e/ou ocupação:

atividade remunerada fora de casa ( ) $\operatorname{sim}$ ( ) não atividade remunerada em casa ( ) sim ( ) não

Tem alguma renda? Descreva o valor em número de salários mínimos:

onde mora ( cidade e estado):
( ) zona rural
( ) zona urbana

Quem são as pessoas que moram com você? ( colocar o nível de parentesco ou o tipo de relação que existe entre vocês):

Das pessoas que moram com você, quem são as que trabalham e no que trabalham

\section{2) Quanto ao histórico da lesão medular}

idade em que ocorreu a lesão:

Qual o nível e causa de sua lesão: 


\section{3) Quanto ao trabalho/estudos e, relacionamento social}

No momento você está estudando ou trabalhando? Se não, conte-me quando e porque parou de estudar ou trabalhar. Se sim, diga-me o que estuda ou em que trabalha e qual o significado que este trabalho teve ou tem para você, após a ocorrência da sua lesão.

Você encontrou ou encontra algum obstáculo para conseguir estudar ou trabalhar? Se sim, qual (is) foi (am) ou é (são) e o que fez ou faz diante disto.

Acha que uma deficiência física pode ter alguma influência no ambiente de trabalho, ou mesmo na sua execução? Qual (s) e porquê?

Como você acha que as pessoas que trabalham ou trabalharam com você lhe percebe $(\mathrm{m}) /(\mathrm{ram})$ ? E porquê? Como você se sente ou se sentia em relação a isto?

Como é o seu relacionamento com as pessoas que convivem de uma forma geral? Como é o seu convívio social e o que isto significa para você?

Percebeu alguma mudança na sua vida social e afetiva com o advento da lesão medular? Se sim, qual (is) e de que forma ela (s) ocorreu (ram)?

Você considera que existe preconceito em relação ao deficiente? E, em relação à você, Sente-se ou já se sentiu discriminado de alguma forma? Em caso afirmativo, que fez ou faz diante disto?

Faz parte de alguma associação voltada para pessoas com deficiência? Como vê a atuação destas associações?

\section{4) Percepções em relação à lesão medular}

Conte-me como adquiriu a lesão medular:

Ao adquirir esta deficiência, quais eram os seus conhecimentos sobre a lesão medular?

Como você se sentiu quando se percebeu na condição de lesado medular?

Qual (is) a (s) mudança (s) que a lesão medular trouxe para a sua vida?

Na sua concepção, quais são os aspectos positivos e negativos advindos de uma deficiência como a sua? E o que ela representa para você?

O que acredita ser a sua maior dificuldade? E do portador de lesão medular como um todo?

O que, na sua concepção, o deficiente físico mais necessita?

Caso você não tivesse adquirido uma lesão medular, como seria sua vida hoje?

Você se considera uma pessoa dependente? Porquê? 


\section{5) Quanto ao aspecto familiar}

Como a sua família reagiu a sua deficiência e como ela tem lidado com este fato?

Como é o seu relacionamento com as pessoas da sua família?

Algum membro de sua família tem participado do seu processo reabilitacional? Como você avalia esta participação? Ela tem contribuído de alguma forma neste processo e porque?

\section{6) Quanto a reabilitação}

O que você entende por reabilitação?

Já esteve em processo de reabilitação anteriormente? Onde? Quantas vezes e por quanto tempo? Como foi?

Encontrou alguma dificuldade em frequentar serviços de assistência à saúde e reabilitação? Se sim, quais foram e porquê?

Acha que obteve benefícios com os serviços de reabilitação que participou ou participa? Se sim, relate quais seriam e também àquele considerado mais importante para você:

5) Com relação às concepções e expectativas em relação à Estimulação Elétrica Neuromuscular ( EENM).

Como e porquê procurou a EENM?

O que você entende por EENM? Você considera que obteve todas as informações necessárias sobre este tipo de tratamento?

A EENM trouxe alguma mudança significativa para a sua vida? Qual e porquê?

Mudanças em relação a atividades de vida diária e prática:

Mudanças no seu relacionamento familiar e social:

Mudanças em relação à forma de se perceber

Quais eram as suas expectativas ao entrar no Programa EENM? Se houve mudanças no decorrer do tratamento, diga quais foram elas e porquê elas ocorreram:

O que espera em relação a este tratamento?

O que você mudaria e o que você não mudaria no funcionamento do programa de EENM?

Quais os profissionais que, para você, devem fazer parte da equipe de reabilitação? O que você pensa sobre a inserção de um psicólogo na mesma e que tipo de intervenção você acha que esse profissional deveria exercer num programa como este?

Quais são as suas expectativas em relação ao futuro? 
APÊNDICE B - Formulário para caracterização dos familiares 


\section{Formulário para Caracterização do Familiar}

Familiar:

Sujeito:

grau de parentesco: $\operatorname{sexo}() \mathrm{F} \quad($ ) M

idade: cor

estado civil/marital:

escolaridade: ( ) $1^{\circ}$ grau completo ( ) incompleto

( ) $2^{\circ}$ grau completo ( ) incompleto

( ) superior completo ( ) incompleto

( ) lê e escreve com dificuldade

( ) não sabe ler e escrever., mas assina o nome

( ) não sabe ler e escrever.

prática espiritual / religião:

profissão e ocupação:

atividade remunerada fora de casa ( ) sim ( ) não atividade remunerada em casa ( ) sim ( ) não

renda familiar (número de salários mínimos):

onde mora ( cidade e estado):

( ) interior ( ) capital

( ) zona rural ( ) zona urbana

Quem são as pessoas que moram com você? ( colocar o nível de parentesco ou o tipo de relação que existe entre vocês):

Vocês sempre moraram neste local? Com as mesmas pessoas? Se houve mudanças relate quantas vezes elas ocorreram e de que tipos foram: 
APÊNDICE C - Termo de Consentimento Esclarecido 


\section{Unidade de Reabilitação do Aparelho Locomotor \\ Programa de Estimulação Elétrica Neuromuscular \\ Departamento de Ortopedia e Traumatologia - FCM/UNICAMP}

\section{Estudo dos Aspectos Psicológicos dos Pacientes Brasileiros Envolvidos no Tratamento para Reabilitação Motora Através da Estimulação Elétrica Neuromuscular}

Termo de Consentimento Esclarecido

$\mathrm{Eu}$, portador do RG no.

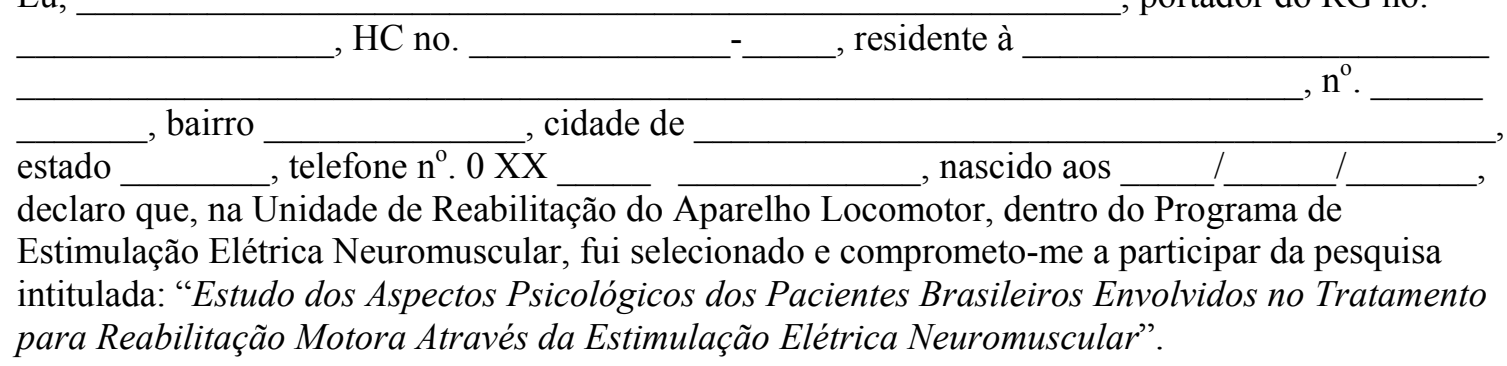

Para tanto, fui devidamente informado sobre o seguinte:

1. Que trata-se de um procedimento de pesquisa na qual não haverá danos físicos ao participante, sendo resguardado o sigilo em relação à sua identidade.

2. Que o objetivo geral desta pesquisa é o entendimento do paciente submetido à Estimulação Elétrica Neuromuscular nos seus aspectos psicológicos e/ou comportamentais em geral. Propõe o aperfeiçoamento do trabalho realizado no Programa de EENM, efetivando ao máximo seus efeitos positivos sobre o paciente e procurando adequar o mesmo aos objetivos do tratamento, ou seja, sua melhora e reabilitação.

3. Que poderei, a qualquer momento, requerer o direito de anular minha participação neste estudo, sem que venha a ser prejudicado nos demais atendimentos.

4. Que os resultados poderão ser utilizados para publicação científica.

5. Que serão respeitados os aspectos éticos envolvidos na abordagem proposta, baseando-se no respeito à dignidade e integridade do paciente participante.

6. Que esta pesquisa, assim com as demais envolvidas neste programa, é coordenada pelo Prof. Dr. Alberto Cliquet Jr.

7. Que na condição de participante desta pesquisa, poderei ser submetido a métodos de avaliação específicos da psicologia, como testes psicométricos, entrevistas e análises comportamentais.

8. Que assumirei a responsabilidade de direcionar o questionário até a minha família, com o objetivo de trazê-lo de volta preenchido, se isto for solicitado pela pesquisadora.

9. Que terei acesso aos resultados, assim como à esclarecimentos sobre a pesquisa durante e após o seu encerramento, sempre que houver interesse ou assim desejar.

Campinas, SP, , de de 2002 . 
ANEXO A - SISTEMA IBGE DE RECUPERAÇÃO AUTOMÁTICA - SIDRA, TABELA 1649 - POPULAÇÃO RESIDENTE POR SITUAÇÃO, SEXO E TIPO DE DEFICIÊNCIA 
ANEXO B - Parecer do Comitê de Ética da UNICAMP 
COMITÊ DE ÉTICA EM PESQUISA

Caixa Postal 6111

13083-970 Campinas, SP

율 (0_19) $3788-8936$

UNICAMP

fax (0_19) 3788-8925

CEP, 20/08/02

(Grupo III)

PARECER PROJETO: $\mathrm{N}^{\circ}$ 031/2002

I-IDENTIFICAÇ̃̃O:

PROJETO: "ESTUDO DOS ASPECTOS PSICOLÓGICOS DOS PACIENTES

BRASILEIROS ENVOLVIDOS NO TRATAMENTO PARA REABILITAÇ̃̃O

MOTORA ATRAVÉS DA ESTIMULAÇÃO ELÉTRICA NEUROMUSCULAR"

PESQUISADOR RESPONSÁVEL: Renata Borges Manhães

INSTITUIÇÃO: Departamento de Cirurgia/FCM/UNICAMP

APRESENTAÇÃO AO CEP: 30/01/2002

\section{II - OBJETIVOS}

Avaliar os aspectos psicológicos de pacientes com lesão medular envolvidos em um programa de reabilitação

\section{III - SUMÁRIO}

Serão avaliados pacientes com lesões medulares, divididos por faixa etária e tipo de lesão, sob determinados aspectos psicológicos do paciente e da familia. As entrevistas buscam identificar carateristicas especificas dos indivíduos e traçar um perfil psicologico dos mesmos.

\section{IV - COMENTÁRIOS DOS RELATORES}

O protocolo foi adequado as sugestões do Comitê, estando de acordo com as normas da Resolução 196/96 CNS-MS e suas complementares. Recomendamos sua aprovação.

\section{$V$ - PARECER DO CEP}

O Comitê de Ética em Pesquisa da Faculdade de Ciências Médicas da UNICAMP, após acatar os pareceres dos membros-relatores previamente designados para o presente caso e atendendo todos os dispositivos das Resoluções 196/96 e 251/97, bem como ter 
aprovado o Termo do Consentimento Livre e Esclarecido, assim como todos os anexos incluidos na Pesquisa, resolve aprovar sem restrições o Protocolo de Pesquisa supracitado.

\section{VI - INFORMACÕES COMPLEMENTARES}

O sujeito da pesquisa tem a liberdade de recusar-se a participar ou de retirar seu consentimento em qualquer fase da pesquisa, sem penalização alguma e sem prejuizo ao seu cuidado (Res. CNS 196/96 - Item IV.1.f) e deve receber uma cópia do Termo de Consentimento Livre e Esclarecido, na integra, por ele assinado (Item IV.2.d).

Pesquisador deve desenvolver a pesquisa conforme delineada no protocolo aprovado e descontinuar o estudo somente após análise das razões da descontinuidade pelo CEP que o aprovou (Res. CNS Item III.1.z), exceto quando perceber risco ou dano não previsto ao sujeito participante ou quando constatar a superioridade do regime oferecido a um dos grupos de pesquisa (Item V.3.).

O CEP deve ser informado de todos os efeitos adversos ou fatos relevantes que alterem o curso normal do estudo (Res. CNS Item V.4.). É papel do pesquisador assegurar medidas imediatas adequadas frente a evento adverso grave ocorrido (mesmo que tenha sido em outro centro) e enviar notificação ao CEP e à Agência Nacional de Vigilância Sanitária - ANVISA - junto com seu posicionamento.

Eventuais modificações ou emendas ao protocolo devem ser apresentadas ao CEP de forma clara e sucinta, identificando a parte do protocolo a ser modificada e suas justificativas. Em caso de projeto do Grupo I ou II apresentados anteriormente à ANVISA, o pesquisador ou patiocinador deve enviá-las também à mesma junto com o parecer aprovatório do CEP, para serem juntadas ao protocolo inicial (Res. 251/97, Item III.2.e)

Relatórios parciais e final devem ser apresentados ao CEP, de acordo com os prazos estabelecidos na Resolução CNS-MS 196/96.

Atenção: Projetos de Grupo I serão encaminhados à CONEP e só poderão ser iniciados após Parecer aprovatório desta.

\section{VII - DATA DA REUNIÃO}

Homologado na VIII Reunião Ordinária do CEP/FCM, em 20 de agosto de 2002.

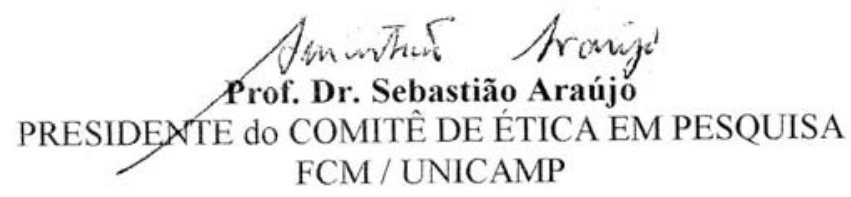




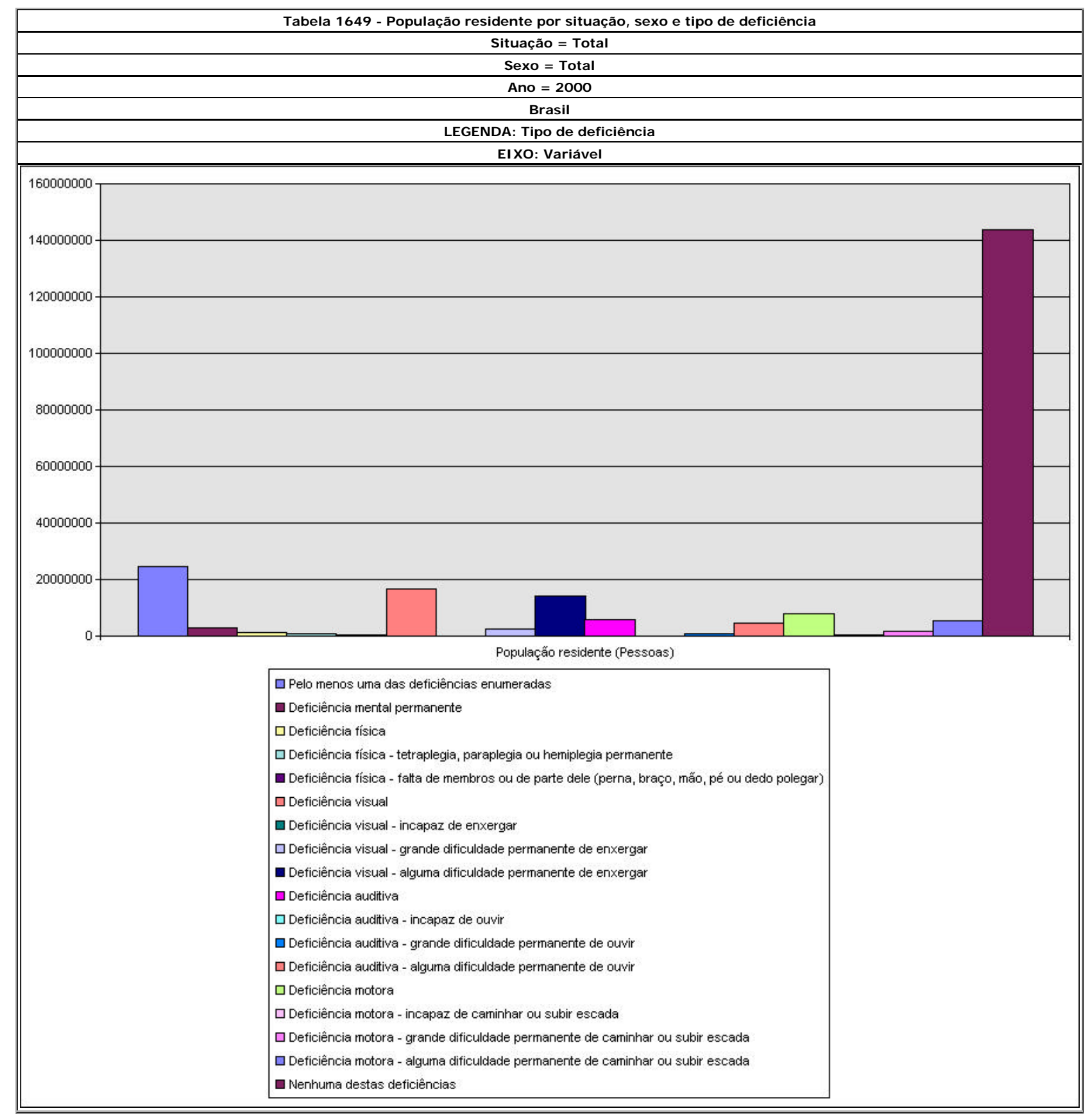

\begin{tabular}{|c|c|c|}
\hline \multicolumn{3}{|l|}{ Situação = Total } \\
\hline \multicolumn{3}{|l|}{ Sexo $=$ Total } \\
\hline \multicolumn{3}{|l|}{ Ano $=\mathbf{2 0 0 0}$} \\
\hline \multicolumn{3}{|l|}{ Brasil } \\
\hline Tipo de deficiência & Variável & \\
\hline Pelo menos uma das deficiências enumeradas & População residente (Pessoas) & 24.537 .985 \\
\hline Deficiência mental permanente & População residente (Pessoas) & 2.848 .684 \\
\hline Deficiência física & População residente (Pessoas) & 1.422 .223 \\
\hline Deficiência física - tetraplegia, paraplegia ou hemiplegia permanente & População residente (Pessoas) & 955.287 \\
\hline Deficiência física - falta de membros ou de parte dele (perna, braço, mão, pé ou dedo polegar) & População residente (Pessoas) & 466.937 \\
\hline Deficiência visual & População residente (Pessoas) & 16.573 .937 \\
\hline Deficiência visual - incapaz de enxergar & População residente (Pessoas) & 159.823 \\
\hline Deficiência visual - grande dificuldade permanente de enxergar & População residente (Pessoas) & 2.398 .471 \\
\hline Deficiência visual - alguma dificuldade permanente de enxergar & População residente (Pessoas) & 14.015 .641 \\
\hline Deficiência auditiva & População residente (Pessoas) & 5.750 .809 \\
\hline Deficiência auditiva - incapaz de ouvir & População residente (Pessoas) & 176.066 \\
\hline Deficiência auditiva - grande dificuldade permanente de ouvir & População residente (Pessoas) & 860.889 \\
\hline Deficiência auditiva - alguma dificuldade permanente de ouvir & População residente (Pessoas) & 4.713 .855 \\
\hline Deficiência motora & População residente (Pessoas) & 7.879 .601 \\
\hline Deficiência motora - incapaz de caminhar ou subir escada & População residente (Pessoas) & 588.202 \\
\hline Deficiência motora - grande dificuldade permanente de caminhar ou subir e & População residente (Pessoas) & 1.799 .917 \\
\hline
\end{tabular}


Deficiência motora - alguma dificuldade permanente de caminhar ou subir escada Nenhuma destas deficiências
População residente (Pessoas) $\quad 5.491 .481$

População residente (Pessoas) 143.769 .672

\section{Nota:}

1 - Os dados são dos Resultados Preliminares da Amostra

2 - As pessoas com mais de um tipo destas deficiências foram contadas apenas uma vez na categoria Total

3 - A categoria Total inclui as pessoas sem declaração destas deficiências

4 - As pessoas com mais de um tipo destas deficiências foram incluídas em cada um dos tipos que tinha

5 - A categoria Nenhuma destas deficiências inclui as pessoas sem qualquer tipo de deficiência

6 - Os Resultados Preliminares da Amostra foram obtidos por uma pequena amostra dos domicílios e pessoas pesquisados pelo Censo 2000. Tais estimativas, portanto, têm diferentes níveis de precisão dependendo da natureza da informação. 0 Coeficiente de Variação calculado para cada uma das células das tabelas apresentadas dão uma medida da precisão dessas estimativas. Esses coeficientes têm valores que variam a partir de zero, quando a estimativa coincide com o valor censitário conhecido, aumentando quando o nível de precisão diminui.

\section{Fonte: I BGE - Censo Demográfico}

